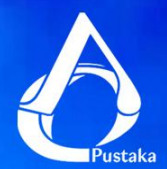

\title{
ISMAIL MARZUKI
}

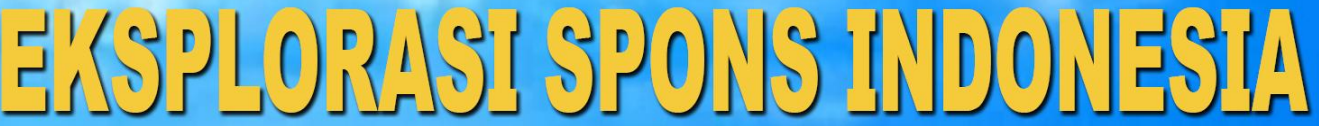

\section{SEPGUAR KEPULAUAN SPERMONDE}

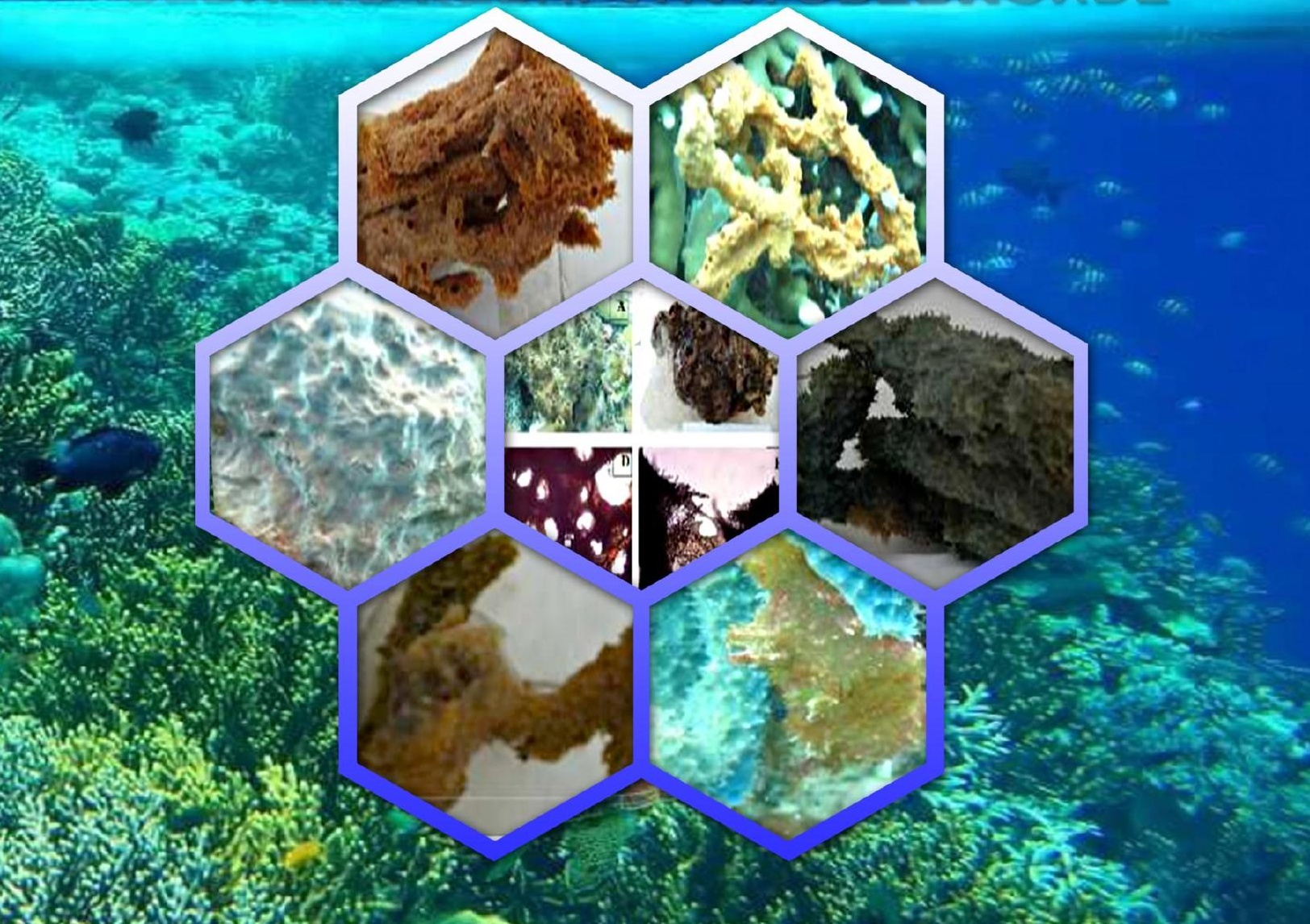


Kekayaan Alam Hayati Laut

\title{
EKSPLORASI SPONS INDONESIA: \\ SEPUTAR KEPULAUAN SPERMONDE
}

\section{Oleh:}

\section{Ismail Marzuki}

\author{
Tim Editor \\ Prof. Dr. Alfian Noor, M.Sc \\ Ratna Surya Alwi, ST., M.Si., Ph.D \\ Dr. Erniati, ST., MT
}

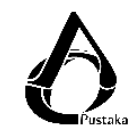

Diterbitkan oleh

Penerbit Nas Media Pustaka

Makassar, 2018 


\section{Sanksi Pelanggaran Pasal 72}

\section{Undang-Undang Nomor 19 Tahun 2002 Tentang HAK CIPTA}

1. Barangsiapa dengan sengaja melanggar dan tanpa hak melakukan perbuatan sebagaimana dimaksud dalam Pasal 2 ayat (1) atau Pasal 49 ayat (1) dan ayat (2) di pidana dengan pidana penjara masing-masing paling singkat 1 (satu) bulan dan/atau denda paling sedikit Rp.1.000.000,00 (satu juta rupiah) atau pidana penjara paling lama 7 (tujuh) tahun dan/atau denda paling banyak Rp.5.000.000.000,00 (lima miliar rupiah).

2. Barangsiapa dengan sengaja menyiarkan, memamerkan, mengedarkan, atau menjual kepada umum suatu ciptaan atau barang hasil pelanggaran Hak Cipta atau hak terkait sebagaimana dimaksud pada ayat (1) dipidana dengan pidana penjara paling lama 5 (lima) tahun dan/atau denda paling banyak Rp.500.000.000,00 (lima ratus juta rupiah) 


\section{Ucapan Terima Kasih:}

Ucapan terima kasih disampaikan kepada Direktur Jenderal Penguatan Riset dan Pengembangan Kemenristek Dikti RI atas pembiayaan penulisan buku ini dengan judul: Eksplorasi Spons

Indonesia: Seputar Kepulauan Spermonde, melalui skema PPT-2017 (Tahun pertama)dan

PSN-2018 (tahun kedua)

dalam tiga tahun usulan penelitian. 


\section{EKSPLORASI SPONS INDONESIA;}

SEPUTAR KEPULAUAN SPERMONDE

Ismail Marzuki

- Makassar : (C) 2018

Tim Editor

Prof. Dr. Alfian Noor, M.Sc

Ratna Surya Alwi, ST., M.Si., Ph.D

Dr. Erniati, ST., MT

$\begin{array}{ll}\text { Layout } & \text { : Nas Media Creative } \\ \text { Design Cover }: \text { Nas Media Creative }\end{array}$

Copyright (c) Ismail Marzuki 2018

Hak cipta ada pada Penerbit Nas Media Pustaka

All right reserved

Cetakan Pertama, Mei 2018

Diterbitkan oleh Penerbit Nas Media Pustaka

CV. Nas Media Pustaka

Anggota IKAPI

Jl. Batua Raya No. 550 Makassar 90233

Telp. 0811-43222-71 / 0853-6363-5252

redaksi@nasmediabooks.com

www.nasmediapustaka.co.id

www.nasmediabooks.com

Instagram : @nasmediapustakapenerbit

Fanspage : Penerbit Nas Media Pustaka

Perpustakaan Nasional: Katalog Dalam Terbitan (KDT)

Ismail Marzuki.

Eksplorasi Spons Indonesia; Seputar Kepulauan

Spermonde/Ismail Marzuki; Editor, Alfian Noor, Ratna Surya

Alwi, Erniati; -cet. I-Makassar : Nas Media Pustaka, 2018.

xvi + 198 hlm; 17 x 25 cm

ISBN 978-602-5662-XX-X

I. Referensi II. Judul 


\section{Prakata}

Potensi spons Indonesia mencapai 80 persen dari populasi spons dunia. Spons adalah jenis hewan paling unik di dunia. Spons merupakan hewan kecil yang diklaim paling tua di dunia. Potensi pemanfaatan spons sangat luas terutama pemanfaatan kanduangan zat aktif dalam bidang kesehatan, pemanfaatan mikrosimbion dan biomassa dalam bidang pengolahan limbah hidrokarbon sebagai biodegradator dan penanganan limbah logam berat dengan metode bioabsorpsi, serta potensi pengembangan ekstrak sebagai anti bakteri pathogen, biomaterial pada cat, serta potensi zat berperilaku enzim untuk mengatasi keretakan pada tembok, adalah bagian dari sekian banyak pemanfaatan spons. Eksplorasi spons untuk mencapai hasil maksimal, membutuhkan kolaborasi berbagai pihak dapat menjadikan spons sebagai objek riset masa depan oleh para peneliti handal Indonesia dan dunia.

Eksplorasi spons itu membutuhkan berbagai pengetahuan, kreativitas, wawasan dan metode serta kearifan dalam melakukannya untuk tujuan penerapan dan pengembangan, serta dibutuhkan kolaborasi berbagai disiplin ilmu, peran regulasi pemerintah dan berbagai komitmen investasi untuk menuju pada hasil nyata berupa produk inovasi pada banyak bidang. Hal ini menjadikan spons sebagai hewan yang penting dan patut dilingdungi bahkan kedepan bisa jadi merupakan hewan langka yang dikejar-kejar oleh manusia.

Upaya pelestarian spons dengan melakukan transplantasi, regulasi kawasan konservasi, zona perlindungan adalah usaha untuk menjaga kelestarian spons di habitat alaminya agar terhindari dari ancaman kepunahan karena banyaknya predator dan ancaman hancurnya populasi spons karena ulah manusia dalam usaha penangkapan yang kerap kali menggunakan bom/ racun ikan, aktivitas reklamasi pantai yang saat ini menjadi tren dan mungkin juga karena pengembangan kawasan dalam usaha wisata yang dikelola tidak bijak. Gugusan Kepulauan Spermonde di Sulawesi Selatan, Kepulauan Seribu di Jakarta dan kawasan Laut Bunaken adalah area yang dapat dijadikan sebagai kawasan zonanisasi biota laut termasuk spons.

Buku ini berisi berbagai informasi tentang spons, fisiologi, morfolagi dan anatomi, histologi, fenotip, genotip spons termasuk berbagai komponen yang terkandung dalam spons baik sebagai biomassa, zat aktif maupun mikrosimbion hasil penelitian, baik yang dilakukan sendiri oleh penulis maupun hasil penelitian kolega dalam skop nasional dan mungkin lintas negara serta regional-internasional yang dilakukan dalam rangka pemenuhan kebutuhan hidup manusia, dilaksanakan dengan berbagai metode sampai pada pemanfaatan khususnya untuk berbagai 
kepentingan. Pengunggakapan tentang sekelumit spons sebagai hasil berbagai riset yang dilakukan terkait, dalam 1 dekade terakhir dan masih sedang berlangsung hingga saat ini dan beberapa tahun ke depan, nampaknya menjadikan spons sebagai objek riset dan potensi biomaterial termasuk dalam penanganan lingkungan berkelanjutan.

Ucapan terima kasih disampaikan kepada Bapak Prof. Dr. Alfian Noor, M.Sc, selaku promotor yang telah banyak mendorong penulis untuk membukukan disertasi dan juga kesediaannya menjadi editor dalam penulisan buku ini, Terima kasih pula kepada Bapak Rektor UNIFA yang banyak membantu dan mendorong setiap dosen untuk senantiasa berkarya yang diistilahkan dengan tagline "Demonstrasi akademik", dan terkhusus ucapan terima kasih kepada Direktorat Jenderal Penelitian dan Pengabdian Kepada Masyarakat Simlitabmas RistekDikti sebagai penyandang dana dalam penelitian dan penulisan buku ini dalam skema hibah PPT-2016 dan PSN-2017.

Harapan yang ingin dicapai sebagai tujuan dari ditulisnya buku ini, agar masyarakat Indonesia pada khususnya dan populasi dunia pada umumnya dapat memahami dan bijak dalam melakukan eklplorasi dan ekploitasi biota laut, khususnya spons, karena kepunahan satu jenis biota laut berdampak besar pada ekosistem yang membutuhkan waktu sangat panjang dalam pemulihannya, meski proses pemulihan alamia ada bahkan adanya intervensi teknologi, metode sekalipun yang melibatkan seluruh aspek pengetahuan dan perkembangan ilmu pengetahuan manusia. Eksplorasi spons secara maksimal dapat mengubah arah perkembangan ilmu pengetahuan manusia, sehingga pada akhirnya berdampak pada kualitas hidup manusia apakah lebih baik atau mungkin mengalami kemuduran, semoga tidak, amiin.

Penulis, 


\section{Pengantar Editor}

Mengutarakan sebuah gagasan, ide, pengetahuan seseorang yang dilakukan dengan menulis, baik berupa artikel sederhana, opini buku, cerpen, hikayat, risalah, biografi dan lain sebagainya adalah sebuah pekerjaan yang tidak gampang dan tidak banyak orang yang dapat mewujudkannya. Setiap orang yang sehat secara mental, dapat dipastikan memiliki gagasan, namun tidak semua orang dapat mengutarakan gagasan tersebut dengan menulis yang menghasilkan buku.

Buku ini mengurai dengan jelas tentang spons, dengan mengangkat topik-topik menarik. Sub-sub tema yang tepat dan spesifik disampaikan dalam bahasa yang lugas, sehingga menbacanya tidak lekas menimbulkan kebosanan. Informasi dalam buku ini cukup urgen bagi banyak kalangan, bukan hanya para akademisi, mahasiswa dan pelajar, tetapi dapat menyasar pada banyak pihak sebagai referensi dan juga dapat memenuhi kebutuhan pemerintah pusat dan daerah untuk melahirkan suatu kebijakan terkait dengan pelestarian biota laut, khusus spons.

Isi buku ini juga sebagai bentuk penyebarluasan hasil-hasil riset yang telah dilakukan selama ini, karenanya buku ini bukan merupakan fiksi, opini atau hayalan, tetapi berupa karya sastra yang menyampaikan informasi ilmiah dan fakta-fakta riset yang berusaha mengangkat potensi alam hayati laut Indonesia, agar pandangan terhadap biota laut khususnya spons bukan hanya sekedar objek yang dipandangi dan dinikmati keindahannya, akan tetapi sebagai sebuah sosok hewan unik yang memiliki potensi besar apabila dieksplorasi dan dieksploitasi dengan bijak, dapat memenuhi kebutuhan manusia dengan mengobtimalkan potensi spons dengan kandungan zat aktifnya, mikrosimbion dan biomassa yang ada untuk berbagai kemanfaatan pada bidang kesehatan/farmasi, biodegradasi, bioabsorpsi komponen limbah.

Review informasi yang menjadi isi buku ini tidak mudah dilakukan karena materi yang tersaji dalam buku ini merupakan kolaborasi wawasan pada banyak bidang, seperti biologi, budidaya, kimia, farmasi dan bidang lainnya yang terkait, meski demikian buku ini menyuguhkan informasi ilmiah yang dapat menambah khasana dan wawasan kita. Apresiasi kepada Saudara Ismail Marzuki yang mampu menyampaikan temuan-temuan risetnya yang selama ini dilakukan sejak mengikuti pendidikan program doktoral hingga saat ini yang tetap konsisten pada objek penelitian tentang spons dan aplikasinya pada lingkungan.

\section{E d i t o r,}

Prof. Dr. Alfian Noor, M.Sc 


\section{Daftar Isi}

Prakata

Pengantar Editor

Daftar Isi

Daftar Tabel

Daftar Gambar

Bab 1 Mengenal Sposn Indonesia

1.1 Spons Seputar Kepulauan Spermonde, Sebuah Pengantar

1.2 Identitas Spons

1.3 Penggolongan Spons

1.4 Cara Hidup dan Habitat Spons

1.5 Keunikan Spons (Karakter dan corak)

1.6 Struktur Spons

$\mathrm{v}$

vii

ix

xii

xiii

1

Bab 2 Fisiologi, Anatomi, Morfologi dan Histologi Spons 17

$\begin{array}{lll}2.1 & \text { Fisiologi Spons } & 17\end{array}$

2.1.1 Fisiologi Bentuk dan Permukaan Tubuh 19

2.1.2 Fisiologi pencernaan dan ekskresi 23

2.1.3 Fisiologi pernafasan 24

2.1.4 Fisiologi Syaraf 24

2.1.5 Fisiologi Osmoregulasi 25

2.2 Anatomi 25

2.2.1 Anatomi Spons 25

2.2.2 Ciri-ciri Anatomi Spons 27

2.3 Morfologi Spons 30

2.3.1 Pengantar Morfologi Spons 30

2.3.2 Ciri-ciri Morfologi Spons 32

2.4 Histologi Spons 38

Bab 3 Mikrosimbion Spons $\quad 45$

3.1 Spons dan Mikroorganisme 45

3.2 Faktor yang Mempengaruhi Terjadinya Mikrosimbion Spins $\quad 47$

3.2.1 Ketersediaan Nutrien $\quad 47$

3.2.2 Salinitas, Temperatur dan $\mathrm{pH} \quad 48$

3.2.3 Tofografi $\quad 48$

3.2.4 Ancaman Pencemaran 49

3.2.5 Arus Laut, Kedalaman dan Gelombang 49

3.3 Hubungan Mikrosimbion terhadap Jenis Spons $\quad 50$

3.3.1 Interaksi Spons Terhadap Mikroorganisme $\quad 50$

3.3.2 Isolasi Mikrosimbion Spons 51

3.3.3 Metode Pemisahan Biomassa Spons Laut 52 
3.3.4 Pemurnian Isolat Bakteri Simbion Spons Laut 53

3.4 Karakterisasi Mikrosimbion Spons 56

3.4.1 Metode Pewarnaan gram dan pengamatan morfologi isolat

3.4.2 Metode Permurnian dan Uji Biokimia isolat Mikrosimbion Spons

3.4.3 Metode Penentuan Spesies Isolat dengan Metode Polimerase Chain Reaction (PCR) (Metode Genotif

3.4.4 Penentuan jumlah koloni suspensi bakteri dan biomassa spons

3.4.5 Penentuan jumlah sel bakteri masing-masing suspensi yang akan digunakan untuk Aplikasi dalamMetode degradasi limbah sludge minyak bumi (SMB)

Bab 4 Karakterisasi Spons

4.1 Analisis Biomassa Spons 65

4.2 Analisis Fenotif Spons 68

4.2.1 Analisis Fenotip Metode Pewarnaan gram Isolat Tunggal

4.2.2 Analisis fenotip melalui uji biokimia isolat 72

4.3 Analisis Genotip Spons $\quad 74$

Bab 5 Karakteristik Lingkungan, Ekstraksi dan Daya Hambat Mikrosimbion

5.1 Karakteristik Lingkungan Habitat Spons

5.2 Terumbu Karang dan Keberadaan Spons $\quad 83$

5.2.1 Definisi Karang dan Tutupan Karang 83

5.2.2 Karang Lunak vs Karang Batu $\quad 85$

5.2.3 Karang Batu dan Invertebrata Kerabatnya 86

$\begin{array}{ll}\text { 5.2.4 Terumbu Karang } & 87\end{array}$

5.2.5 Karang dan Terumbu Karang 89

5.3 Habitat Spons dan Metabolik Sekunder $\quad 89$

5.3.1 Pengamatan Kondisi Habitat Spons $\quad 89$

5.3.2 Pengamatan Kandungan Metabolit Sekunder Spons 91

5.4 Ekstraksi Spons 97

5.5 Daya Hambat Ekstrak Spons Sebagai Anti Bakteri dan Jamur 98

5.5.1 Metode Kerja 99

5.5.2 Pengujian Daya Hambat Ekstrak Spons Terhadap Aktivitas Antibakteri 104

5.5.3 Analisis Diameter zona hambat 104

5.5.4 Uji Sitotoksisitas Ekstrak Senyawa Aktif Spons Kaliapsis sp 
Bab 6 Potensi Aplikasi Spons dan Mikrosimbion

6.1 Senyawa Bioaktif Spons dan Potensi
Pengembangannya

6.1.1 Kandungan Alkaloid Spons 117

6.1.2 Kandungan steroid, Turunan Phenil dan Serebrosida 118

6.2 Enzim sebagai Komponen Unik Spons 119

6.3 Zat Aktif Spons Sebagai Antioksidan 122

Bab 7 Sebaran Spons Indonesia dan Ancaman Kepunahan 127

$\begin{array}{lll}7.1 & \text { Spons pada Kepulauan Spermonde } & 127\end{array}$

7.2 Sebaran Spons Indonesia 132

7.3 Sebaran Spons Dunia 135

7.4 Spons dalam Ancaman Kepunahan 137

Bab 8 Spons Sebagai Objek Riset Masa Depan 141

8.1 Karakterisasi Zat Aktif Spons 141

8.2 Komponen Pengedradasi 149

8.3 Spons Sebagai Bioabsorpben Logam Berat 151

8.4 Potensi Mikrosimbion Spons Sebagai Biomaterial 153

8.5 Spons Objek Potensial Pengembangan Destinasi Wisata 154

Bab 9 Transplantasi Spons $\quad 155$

Bab 9 Transplantasi Spons

9.1 Transplantasi Spons Suatu Metode Pelestarian Aquarium Laut 155

9.2 Metode Transplantasi Spons 156

9.3 Perlukah dilakukan Transplantasi Spons 165

9.4 Syarat dan Faktor-faktor yang Mempengaruhi Transplantasi Spons 167

9.5 Jenis dan Peluang Keberhasilan Transplantasi pada Material Laut 176

9.5.1 Tujuan Transplantasi Bahan Alam Laut 177

9.5.2 Lokasi dan Metode Pelaksanaan Transplantasi Karang 180

9.6 Pertumbuhan Masif Alamiah Spons dalam Metode Transplantasi 184

9.6.1 Tingkat Pertumbuhan Spons Transplantasi 186

9.6.2 Efektifitas Transplantasi Spons 186

Daftar Pustaka

188

Glosarium 201

$\begin{array}{ll}\text { Indeks } & 207\end{array}$

Riwayat Penulis $\quad 216$ 


\section{Daftar Tabel}

Tabel 2.1 Hasil Identifikasi Morfologi spons

Tabel 2.2 Analisis histomorfologi keempat jenis spons asal Pantai

Melawai Balikpapan

Tabel 3.1 Identifikasi Bakteri dari beberapa spons Pulau

Kodingareng Keke

Tabel 3.2 Spesies spons hasil isolasi dan jumlah isolat yang diperoleh serta kode isolat

Tabel 3.3 Panduan pengamatan standar untuk uji biokimia mikroorganisme

Tabel 3.4 Contoh hasil uji fenotip melalui karakterisasi isolat menggunakan standar uji biokimia

Tabel 4.1 Hasil analisis mikroskopik dengan pewarnaan gram bakteri simbion spons Callyspongia sp

Tabel 4.2 Hasil Karakterisasi isolat mikrosimbion spons Callyspongia melalui Uji biokimia

Tabel 4.3 Hasil Karakterisasi isolat mikrosimbion spons Petrosia sp melalui uji biokimia

Tabel 4.4 Hasil BLAST (Basic Local Alignoment Search Tool) isolat mikrosimbion spons Callyspongia sp

Tabel 4.5 Hasil BLAST (Basic Local Alignoment Search Tool) bakteri

Tabel 5.1 Keadaan Lingkungan Lokasi Sampling Spons di Pulau Kodingareng Keke dan sekitarnya

Tabel 5.2 Prosentase Terumbu Karang pada Perairan Pulau Kapoposang

Tabel 5.3 Jenis Sponge dan Habitat yang Dominan pada Setiap Stasiun di sekitar Pulau Kapoposang, Kep. Spermonde

Tabel 5.4 Senyawa Bioaktif yang dihasilkan Spons Laut Menurut Soest dan Brackman

Tabel 5.5 Diameter hambatan Hasil skrining aktivitas anti mikroba ekstrak. Pada Spons dengan konsentrasi $1000 \mu \mathrm{g} / \mathrm{mL}$

Tabel 5.6 Efek Sitotoksik ektram kloroform dan ektrak methanol terhadap sel myeloma

Tabel 5.7 Sitotoksik Gabungan Fraksi I, II, dan III Ekstrak Kloroform Spons Kaliapsis sp, terhadap sel myeloma

Tabel 5.8 Harga hRf bercak-bercak Gf. II

Tabel 5.9 Efek Sitotoksik Bercak 1, 2, 3 dan T dari fraksi Gf. II Spons Kaliapsis sp, terhadap sel myeloma

Tabel 7.1 Beberapa Jenis Spins yang terdapat di Laut Konawe Sulawesi Tenggara

Tabel 9.1 Rata-rata hasil pengukuran parameter kualitas air selama penelitian di perairan Pulau Pari dan Pulau Pramuka

Tabel 9.2 Contoh nilai kualitas Lingkungan pertumbuhan spons 


\section{Daftar Gambar}

$\begin{array}{lll}\text { Gambar 1.1 Struktur Spons secara Umum } & 15\end{array}$

Gambar 1.2 Struktur Kelas Spons secara Umum $\quad 15$

Gambar 2.1 Petrosia (Strongylophora) Corticata Petrosidae diperoleh dari Pulau Kodinganreng Keke

Gambar 2.2 Niphates $s p$ - Niphatidae, diperoleh dari Pulau Kodingareng Keke

Gambar 2.3 Hyrtios arectus- Thorectidae asal Pulau Kodingareng Keke

Gambar 2.4 Clahria (Clathria) basilana asal Pulau Kodingareng Keke

Gambar 2.5 Callyspongia-Cladochalina-glomerata asal Pulau Kodingareng Keke

Gambar 2.6 Auletta $s p$ asalh Pulau Kodingareng Keke

Gambar 2.7 Neopetrosia sp asal Pulau Kodingareng Keke

Gambar 2.8 Callyspongia (Cladochalina) aerizusa asal Pulau Kodingareng Keke

Gambar 2.9 Struktur Morfologi Spons

Gambar 2.10 Pertumbuhan berbentuk Kulit dengan cerobong oscular tinggi berwarna coklat muda; (b) Konsistensi membentuk pola batu yang menunjukkan kekuatan spons; (c) permukaan spons tidak rata dan berlendir

Gambar 2.11 Pertumbuhan berbentuk slighty berupa spons globular dengan oscula ukuran besar

Gambar 2.12 Pertumbuhan spons berbentuk percabangan berwarna hitam

Gambar 2.13 Pertumbuhan spons spesies Clathria (Thalysias) reinwardti, family Microcionidae dengan ciri-ciri bentuk pertumbuhan bercabang-cabang, konsistensi lembut dan kompresibel.

Gambar 2.14 Pertumbuhan Spons spesies Callyspongia sp, masuk dalam family Callyspongiiadae dengan ciri-ciri pertumbuhan berwarna orange, konsistensi rapuh termasuk jika spons tersebut mongering, Choanosom yang tidak berongga

Gambar 2.15 Pertumbuhan Spons Asulleta sp family Axinellida, ordo Axinellida. Pertumbuhan berwarna kuning gelap dengan bentuk tubuh berupa selinder tipis konsistensi rapuh termasuk jika spons tersebut mongering

Gambar 2.16Pertumbuhan spons spesies Neopetrosia sp, family Petrosiid, ordo Halichondrida Pertumbuhan berwarna ungu, membentuk bola, bentuk tubuh konsistensi keras, permukaan halus dan skeleton membentuk 
kerangka multispikuler yang tersusun berbentuk bulat.

Gambar 2.17Pertumbuhan spons spesies Callyspongia aerizusa. family Callysponginade, ordo Haplosclerida. Pertumbuhan berbentuk selinder, warna biru kombinasi kuning, memiliki skeleton berserat primer, memiliki saluran saling berhubungan.

Gambar 2.18Hasil Analisis Histomorfologi spons menggunakan mikroskop Haesisometer spons Callyspongia sp

Gambar 2.19Hasil Analisis Histomorfologi spons Petrosia sp menggunakan mikroskop Haesisometer

Gambar 2.20(A) Bentuk pertumbuhan bergerombol. Kulit berbentuk cerobong memiliki oscular tinggi. bercahaya berwarna coklat muda, (B) Konsistensi: tegas, menunjukkan kekuatan, (C) Permukaan spons yang tidak rata dan berlendir, proyeksi halus, (D) Choanosome dengan kerangka spicule multispicular, (E) Kerangka kurang serat dengan spicule padat dan (F) Spicule: tipe Megasclere: berupa Oksida

Gambar 2.21(A) Bentuk pertumbuhan: Sponge melingkar gligthy, dengan oscula ukuran besar, (B) Konsistensi: permukaan licin, ditutupi oleh lumpur seperti lendir.Tubuh yang tidak elastis dan rapuh, (C) Konsistensi: permukaan licin, ditutupi lumpur seperti lumpur. Spel tubuh yang tidak elastis dan rontok, (D) Kerangknya: berupa spicule dengan spidol echinating, (E) Kerangknya membentuk Pilar trapesium dengan serat tinggi, dan (F) Spicule: megasclera oxea kecil

Gambar 2.22(A) Bentuk Pertumbuhan: spons bercabang Digit. Konsentrat berwarna hitam, (B): Karakteristik yang tidak teridentifikasi, tegas, berdaging, (C) Permukaan berbentuk piramida, (D) Choanosome membentuk bagian potongan tubuh. Berat serat tubuh spong, (E) Kerangka menempel berupa serabut, (F) Spicule: megaplera Substylostyle

Gambar 2.23 Histomorfologi spons spesies a) Callyspongia sp (Gambar kiri) dan b) Coelocarteria singaporensis (Gambar kanan)

Gambar 2.24 Histomorfologi spons spesies a) Callyspongia (Cladocalina) vaginalis (Gambar kiri) dan b) Haliclona (Haliclona) oculata (Gambar kanan)

Gambar 3.1 Hasil isolasi dan analisis morfologi spons Callyspongia sp; (a) hasil isolasi dan penyebaran koloni bakteri; (b) Pertumbuhan koloni hasil purifikasi 
Gambar 3.2 Hasil isolasi bakteri; (a) bakteri sebelum dimurnikan; (b) bakteri hasil isolasi setelah dimurnikan; (c) bakteri setelah disimpan dalam Frezeer

Gambar 3.3 a) Isolat 1; b) isolat 2. Kedua isolat tunggal hasil isolasi dan furifikasi, merupakan mikrosimbion spons

Gambar 4.1 Sebaran fraksi sel spons hasil sentrifugasi

Gambar 4.2 Struktur sel spons Petrosia sp. (a,b,c) adalah spikula pembesaran 200x, dan (d) merupakan medulla spons pembesaran 400x

Gambar 4.3 Contoh hasil analisis mikroskopik dengan pewarnaan gram $\mathrm{a}=$ isolat $\mathrm{A} ; \mathrm{b}=$ isolat $\mathrm{B} ; \mathrm{c}=$ isolat $\mathrm{C}$, yang merupakan isolat hasil isolasi dari spons Petrosia sp

Gambar 4.4 a)Hasil isolasi DNA Genom isolat mikrosimbion spons Callyspongia sp no. 1 genom pembanding dan no. 2 genom sampel; b) hasil amplifikasi genom no. 1 perkiraan base pari (bp) isolat 1 (Sp 1.b.1) dan no. 2 isolat 2 (Sp 1 b. 2); c) hasil amplifikasi isolat 1 dan 2 setelah pemurnian dengan perkiraan $996 \mathrm{bp}$

Gambar 4.5 a) Hasil isolasi DNA Genom (amplifikasi) isolat mikrosimbion spons Petrosia sp. No. 1 adalah genom pembangding dan No. 2 genom sampel. b) merupakan hasil amplifikasi genom 1, diperkirakan base pair (bp) isolat A (Sp1.a.1); Isolat B (Sp1.a.2) dan isolat C (Sp1.a.3). Hasil amplifkasi isolat 1 dan 2 setelah pemurnian dengan perkiraan $996 \mathrm{bp}$

Gambar 4.6 Kromatogram potongan skuen isolat bakteri simbion Callyspongia sp

Gambar 5.1 Sampel sponge stasiun 1, a. Callyspongia aerizusa; b. Agelas clathrdes dan c. Callyspongia falax

Gambar 5.2 Sampel sponge stasiun II. A. Callyspongia aerizusa, b. Meloplus sarasinorum; sedangkan c. Agelas sp yang ditemukan pada stasiun III; serta Agelas sp jenis lainnya yang dominan hidup pada lamun dan pasir ditemukan pada stasiun IV

Gambar 5.3 Histogram kondisi habitat yang dominan dengan diameter hambatan pada mikrosimbion spons callyspongia aeresuza pada stasiun I, II dan III yang ditentukan pada area Pulau Kapoposan, Kepulauan Spermonde

Gambar 5.4 Profil fraksi-fraksi hasil KLT ekstrak spons Kaliapsis

Gambar 5.5 KLT Prefaratif Gf. II dengan fase gerak heksana: etil asetat $1: 2 \mathrm{v} / \mathrm{v}$, dideteksi dengan UV $254 \mathrm{~nm}$

Gambar 5.6 KLT Uji kemurnian bercak 1, 2, dan 3

Gambar 5.7 Profil bercak 1, 2 dan 3

Gambar 6.1 Struktur molekul ATP 
Gambar 7.1 Persentase Penutupan Dasar Perairan(a), \% Komposisi Alga (b), \% Komposisi Lamun; c) Kelimpahan Fauna Lainnya (d) di reef top Pulau Badi

Gambar 8.1 Ekstrak isolat spons Aplysina sp dan Sarphyton sp dengan menggunakan pelarut methanol

Gambar 8.2 Hasil uji KMH ekstrak Aplysina sp dan Sarphyton sp terhadap a. E.coli; b. S. aureus; dan c. C. albicans

Gambar 9.1 Ukuran substrak transplantasi spons

Gambar 9.2 Substrak transplantasi spons yang diikatkan dengan tali

Gambar 9.3 Bentuk dan ukuran potonganbibit spons transplantasi

Gambar 9.4 Bibit uji spons yang telah dipasang pada substrak transplantasi

Gambar 9.5 Bentuk rak dan pengikatan spons pada rak

Gambar 9.6 Pertumbuhan bulanan (cm3) transplantasi spons Petrosia nigricans di Pulau Pari dan Pulau Pramuka di Kepulauan Seribu

Gambar 9.7 Kelangsungan hidup (\%) spons di perairan Pulau Pari dan Pulau Pramuka pada kedalaman 7 meter dan 15 meter

Gambar 9.8 Keadaan morfologi spons pada awal dan akhir transplantasi dengan masa waktu 90 hari

Gambar 9.9 Pertumbuhan spons laut (A) Petrosia sp dan (B) Aaptos aaptos di habitat alami

Gambar 9.10 Salah satu contoh pertumbuhan spons laut transplantasi (A), (B) Petrosia sp dan (C), (D) Aaptos aaptos di habitat alami

Gambar 9.11 Proses negenerasi fragmen spons Petrosia (Petrisia) nigrecans (a) fragmen spons yang baru ditransplantasikan, (b) pemulihan pada bagian yang terpotong, (c) fragmen yang telah pulih terlihat seperti induknya 


\section{Bab -1- \\ MENGENAL SPONS INDONESIA}

\section{1. Spons Seputar Kepulauan Spermonde, Sebuah Pengantar}

Ekosistem laut dan pesisir yang kompleks dengan interaksi yang dinamis memerlukan bentuk pengelolaan yang didasarkan pada pemahaman dan pengetahuan dan evaluasi dari pemanfaatan sumberdayanya oleh masyarakat pengguna agar sumberdaya tersebut dapat dimanfaatkan secara bijak dengan pertimbangan ekologi bagi eksistensi keberadaan ekosistem-ekosistem tersebut.

Pemberlakukan Undang-undang Otoda dan kaitannya dengan dinamika manusia dalam memenuhi kebuthnan hidupnya dipastikan berdampak pada pemanfaatan sumberdaya alam. Survei tentang pemanfaatan sumberdaya oleh primary stakeholder di Kepulauan Spermonde merupakan langkah awal untuk mengetahui masa transisi dalam pengelolaan sumberdaya laut di kepulauan tersebut. Pemahaman pemanfaatan sumberdaya perlu didukung pengetahuan tentang kondisi ekosistem yang dimanfaatkan oleh penduduk pulau di kepulauan Spermonde, terlebih lagi dengan adanya kegiatan reklamasi kawasan Center Point of Indonesia (CPI) dipastikan berdampak negatif terhadap kehidupan biota laut khususnya dikawasan tersebut tidak terkecuali kehidupan spons.

Spons laut merupakan salah satu sumber molekul yang tidak biasa ditemukan di bebatuan jauh sebelum ledakan Kambrium. Bukti paleontologis dan genetik merupakan bukti kuat tentang hal ini, berdasarkan data fosil hasil dieksplorasi diyakini genetik dari molekul spons. Meski demikian, fosil molekul spons yang diyakini ada sebelum ledakan Kambrium, adalah hal aneh dari segi banyak hal, sehingga sangat sulit untuk menentukan spons sebagai jenis hewan pertama. Jika kita berspekulasi, dapat dikatakan bahwa bahwa spons merupakan salah satu hewan nenek moyang yang ada dipermukaan bumi. Tahun 2009 telah dikonfirmasi bahwa tanda-tanda adanya hewan yang dikenal sebagai spons (masa kini) telah ditemukan pada sampel batuan berusia 640 juta tahun dari Oman, berpotensi dapat dipercaya sebagai salah satu bukti yang 
mewakili keberadaan spons sebagai hewan tertua pada kehidupan binatang.

Perilaku spons yang hampir tanpa gerakan dan umumnya ditemukan dengan posisi seperti duduk menyerupai pas bunga, menyebabkan spons pernah dianggap sebagai tumbuhan, anggapan ini berlangsung dalam beberapa waktu lamanya. Penemuan bahwa spons memiliki aliran air dalam tubuhnya, terjadi pada tahun 1765, melahirkan perubahan signifikan terhadap status spons yang dinyatakan sebagai. Selain itu, fakta lain yang menambah keyakinan bahwa spons adalah hewan dapat dilihat susunan sel-selnya merupakan sel hewan dan juga tidak mengandung klorofil sebagaimana tumbuhan/tanaman pada umumnya. Habitat spons tersebar di seluruh perairan terutama yang jernih dan dangkal, sebagian menempel pada substrat atau terumbu karang. Beberapa jenis spons menetap di dasar perairan berpasir, berlumpur, berada pada bagian laut dangkal dan laut dalam.

Indonesia adalah negara kepulauan terbesar di dunia, memiliki wilayah perairan sangat luas, dua pertiga merupakan wilayah laut, dan didalamnya terhadap sumberdaya alam hayati laut yang besar, sehingga bukan tanpa alasan jika populasi dan jumlah spesies spons di Indnesia sukup bervariasi. Salah satu sumber daya alam yang belum banyak dieksplorasi dan pemanfaatannya dalam berbahai bidang kehidupan manusia seperti sumber bahan pangan, sumber bahan utama atau bahan tambahan obat, material pendukung dalam perbaikan lingkungan dan penanganan pencemaran adalah pada ekosistem terumbu karang. Ekosistem terumbu karang merupakan bagian dari ekosistem laut yang menjadi sumber kehidupan bagi beraneka ragam biota laut.

Ekosistem terumbu karang dapat hidup lebih dari 300 jenis karang, lebih dari 200 jenis ikan dan berpuluh-puluh jenis moluska, krustasea, spons, alga, lamun dan biota lainnya. Kandungan utama spons laut adalah senyawa metabolik yang berpotensi sebagai bahan baku obat, dan beberapa jenis spons laut bersimbion dengan mikroorganisme, salah satu diantaranya adalah bakteri. Beberapa jenis spons laut bersimbion dengan bakteri dan dapat mendegradasi hidrokarbon aromatik toksisitas tinggi dengan memanfaatkan karbon pada komponen polisiklik aromatik hidrokarbon (PAH) sebagai sumber sumber energi. Spons juga diketahui 
berfungsi sebagai farmakognosi obat atau antibiotik, spons laut dapat pula bertindak sebagai absorben logam berat.

Beberapa jenis mikroorganisme (isolat bakteri) laut diketahui mampu mendegradasi senyawa hidrokarbon, baik kelompok senyawa alifatik maupun aromatik dengan toksisitas tinggi, antara lain: Pseudomonas, Arthrobacter, Alcaligenes, Brevibacterium, Brevibacillus, dan Bacillus.

Pentingnya pengetahuan tentang material yang dapat mendegradasi limbah mengingat potensi produksi limbah menunjukkan tren peningkatan akibat dari aktivitas manusia dalam memenuhi kebutuhan hidupnya berkontribusi besar terhadap terjadinya pencemaran lingkungan yang pada akhirnya untuk limbah padat dan cair pada alhirnya bermuara di laut. Sumber-sumber pencamran seperti aktivitas industri, transportasi laut, kegiatan eksplorasi dan eksploitasi usaha pertambangan, bongkar muat kapal, kegiatan rumah tangga Sumber limbah minyak bumi dalam lingkungan laut pesisir terdiri atas limbah industri pengolahan, kegiatan eksplorasi, eksploitasi, limbah cair pemukiman (seawage), limbah cair perkotaan (urban stormwater), kecelakaan transportasi (shipping) kapal tangker, kegiatan pertanian, perikanan. Salah satu pencemaran di laut yang sangat utama yang menonjol hingga saat ini adalah kontaminasi hidrokarbon minyak bumi (hidrokarbon petroleum), dapat berwujud cair sampai padat, bervariasi mulai dari yang tidak berwarna sampai berwarna hitam seperti tar (sludge). Kebanyakan minyak mentah (crude oils) berwarna gelap, coklat kekuningan, merah kehitaman atau kehijauan apabila terefleksi cahaya. Bahan pencemar kedua adalah terbentuknya limbah terkontaminasi logam berat yang dapat berasal dari berbagai sumber aktivitas manusia.

Pemanfaatan bahan alam laut spons, biomassa dan mikroorganisme simbion yang bersifat hidrokarbonoklastik dimungkinkan dalam mengatasi cemaran hidrokarbon limbah sludge minyak bumi, khususnya komponen aromatik yang diharapkan, hasil degradasi menghasilkan senyawa organik yang tidak toksik melalui reaksi enzimatik oksigenase. Penggunaan konsorsium bakteri cenderung memberi hasil lebih baik dibandingkan penggunaan bakteri tunggal. Diharapkan kerja enzim dari tiap jenis mikroba dapat saling melengkapi 
untuk dapat bertahan hidup menggunakan sumber nutrien karbon yang tersedia dalam minyak mentah.

\section{2. Identitas Spons}

Porifera dalam bahasa Latin, berarti porus artinya berpori, sedangkan fer artinya membawa. Porifera adalah hewan multiseluler atau metazoa yang paling sederhana. Hewan ini memiliki ciri yaitu tubuhnya berpori seperti busa atau spons, sehingga porifera disebut juga sebagai hewan spons. Ciri-ciri tubuh porifera meliputi ukuran, bentuk, struktur dan fungsi tubuh. Beberapa jenis porifera ada yang seukuran butiran beras, jenis lainnya, tinggi spons raksasa yang ukuran tubuhnya dapat mencapai $2 \mathrm{~m}$ dan diameter hingga 2 meter.

Spons merupakan salah satu jenis kekayaan alam hayati, habitatnya dilaut mencapai 830 spesies yang terdiri dari tiga kelas, yaitu Calcarea, Demospongiae, dan Hexactinellidae, ditemukan pada laut dangkal sampai kedalaman $8.000 \mathrm{~m}$. Pendapat lain menyatakan bahwa filum porifera terdiri dari empat kelas, yaitu: Calcarea, Demospongiae, Hexactinellida, dan Sclerospongia. Tubuh porifera pada umumnya asimetris atau tidak beraturan meskipun ada yang simetris radial. Bentuknya ada yang seperti tabung, vas bunga, mangkuk, atau bercabang seperti tumbuhan. Tubuhnya memiliki lubang-lubang kecil atau berpori (ostium). Warna tubuh bervariasi, ada yang berwarna pucat, dan ada yang berwarna cerah, seperti merah, jingga, kuning bahkan ungu.

Porifera melakukan reproduksi secara aseksual maupun seksual. Reproduksi secara aseksual terjadi dengan pembentukan berupa tunas/pucuk dan gemmule. Gemmule disebut juga tunas internal. Umumnya porifera dapat menghasilkan ovum dan juga sperma pada satu individu, sehingga porifera merupakan hewan bersifat Hemafrodit, yakni jenis hewan yang memiliki 2 jenis kelamin.

Identitas utama spons adalah jenis hewan berpori, bersifat filter feeder (menerap, menyaring dan menyemprotkan) nutrient dalam memperoleh makanan. Spons dapat menjadi habitat bagi mikroorganisme lain dengan bersarang pada tubuh spons. Spons sebagai inang dan sekaligus sebagai tempat untuk bernaung agar tidak terombang-ambing oleh arus laut, sedangkan spons memfungsikan mikroorganisme bersimbionnya sebagai pertahanan diri yang sewaktu-waktu dapat 
menghasilkan zat racun apabila lingkungan perairan spons mengalami perubahan ekstrim akibat pencemaran. Simbion mikroorganisme dengan spons mempunyai dua peran penting dalam sistem biologis spons, pertama sebagai sumber makanan baik oleh mikroorganisme maupun oleh spons, kedua mikrosimbion menjadikan spons sebagai inang untuk kehidupannya dan spons memanfaatkan mikro simbionnya sebagai pertahanan agar dapat beradaptasi dan hidup pada lingkungan ekstrim (lingkungan tercemar). Spons merupakan organisme bersel banyak yang memiliki tubuh penuh pori dan saluran yang memungkinkan air untuk beredar melalui mereka, yang terdiri dari jelly-contoh mesohyl terjepit di antara dua lapisan tipis sel. Spons telah terspesialisasi oleh sel yang dapat berubah menjadi jenis lain dan sering bermigrasi diantara lapisan sel utama dan mesohyl. Spons tidak memiliki saraf, pencernaan atau sistem peredaran darah. Sebaliknya, sebagian besar spons hidup mengandalkan aliran air konstan melalui tubuh mereka untuk memperoleh makanan, oksigen, dan menghilangkan limbah, kondisi aliran air harus dipertahankan.

Identitas lain terkait spons adalah kemampuan untuk bersimbiosis dengan mikroorganisme lain secara mutualisme, baik secara inter maupun intra selular. Spons salah satu organisme hidup, sudah ada sejak 600 juta tahun yang lalu. Spons dapat berasosiasi dengan sejumlah besar mikroorganisme berbeda, contohnya Cyanobacteria, bakteri heterotrofik, alga uniseluler. Spons merupakan hewan multiselular primitif (metazoa) tanpa jaringan nyata. Hewan ini merupakan salah satu objek utama dalam penelitian eksplorasi produk alami. Sekitar 7.000 jenis spons telah dipublikasi. Berdasarkan perkiraan ada sekitar 15.000 spesies spons hidup tersebar di perairan laut dan danau, namun yang berhasil diisolasi baru sekitar 830 jenis, meski jumlah ini berkembang terus. Spons merupakan salah satu komponen biota penyusun terumbu karang yang mempunyai potensi bioaktif yang belum banyak dimanfaatkan. Spons adalah hewan mengandung senyawa aktif dengan persentasi keaktifan lebih besar dibandingkan dengan senyawa-senyawa yang dihasilkan oleh tumbuhan darat.

Spons mempunyai kemampuan untuk menjaring bakteri yang ada disekitarnya sampai $77 \%$ dengan pemanfaatan makanan yang dicerna secara enzimatik. Spons memiliki kemampuan bersimbion dengan bakteri 
indigenous (diisolasi dalam tubuh) dan bakteri eksogenous (diisolasi dipermukaan tubuh) Senyawa bioaktif yang dimiliki oleh spons bermanfaat dalam proses pencernaan, sehingga bioaktif yang diperoleh tentunya bervariasi sesuai dengan kebiasaan makan dari masing-masing jenis spons. Terdapat hubungan simbiotik antara spons dengan sejumlah bakteri dan alga, yaitu spons menyediakan dukungan dan perlindungm bagi simbionnya, sedangkan mikrosimbion menyediakan makanan dan netralisasi lingkungan perairan ekstrim bagi spons. Metabolik yang dihasilkan oleh spons merupakan hasil biosintesis simbionnya sehingga bakteri yang bersimbiosis dengan spons tersebut memiliki komponen yang mirip dengan yang dimiliki pada spons. Spons laut merupakan inang untuk beberapa macam mikroba seperti bakteri, karena dapat melingdungi mikroba dari predator dengan menghasilkan senyawa kimia (metabolik sekunder) yang digunakan untuk menginduksi mikroba yang hidup di dalamnya.

Ciri tubuh porifera meliputi ukuran, bentuk, struktur dan fungsi tubuh. Ukuran dan bentuk sangat beragam. Beberapa jenis porifera ada yang berukuran sebesar butiran beras, sedangkan jenis yang lainnya bisa memiliki tinggi dan diameter hingga 2 meter. Tubuh porifera pada umumnya asimetris atau tidak beraturan meskipun ada juga yang simetris radial. Bentuknya ada yang seperti tabung, vas bunga, mangkuk, atau bercabang seperti tumbuhan. Tubuhnya memiliki lubang kecil (berpori) atau ostium. Warna tubuh bervariasi, ada yang berwarna pucat dan ada yang berwarna cerah, seperti merah, jingga, kuning bahkan ungu.

Struktur dan fungsi tubuh spons khususnya permukaan luar, tersusun atas sel-sel berbentuk pipih dan berdinding tebal yang disebut pinakosit. Pinakosit berfungsi sebagai pelindung. Diantara pinakosit terdapat pori-pori yang membentuk saluran air yang bermuara di spongosol atau rongga tubuh. Spongosol dilapisi oleh sel "berleher" yang memiliki flagelum, yang disebut koanosit. Flagelum yang bergerak pada koanosit berfungsi untuk membentuk aliran air satu arah, sehingga air yang mengandung makanan dan oksigen masuk melalui pori/ostium ke spongosol. Di spongosol, makanan ditelan secara fagositosis (bentuk spesifik endositosis yang melibatkan internalisasi vesikuler terhadap partikel padat) dan oksigen diserap secara difusi oleh koanosit. Sisa pembuangan dikeluarkan melalui lubang yang disebut oskulum. 
Zat makanan dan oksigen, selain digunakan oleh koanosit, sebagian juga ditransfer secara difusi ke bagian sel yang selalu bergerak seperti amoeba, yaitu amoebosit (sel amoeboid), berfungsi mengedarkan makan dan oksigen keseluruh sel tubuh lainnya.

\section{3. Penggolongan Spons}

Penggolongan spons terdiri atas 3 kelas utama dan 1 kelas turunan, sehingga dari beberapa sumber, ada yang mengatakan spons terdiri atas 4 kelas. Penggolongan spons didasarkan pada stuktur tubuh, pola hidup dan pertumbuhannya.

Kelas Calcarea adalah kelas spons yang semuanya hidup di laut. Spons ini mempunyai struktur sederhana dibandingkan yang lainnya. Hidup di daerah pantai yang dangkal. Bentuk tubuhnya sederhana dengan kerangka yang terbuat dari $\mathrm{CaCO}_{3}$. Tinggi Calcarea umumnya kurang dari $10 \mathrm{~cm}$, misalnya Leucosolenia, Clathrina, Grantia, Scypha, dan Sycon. Spikulanya terdiri dari kalsium karbonat dalam bentuk calcite.

Kelas Demospongiae adalah kelompok spons yang dominan di antara porifera masa kini. Umumnya hidup di laut, tetapi ada pula yang hidup di air tawar. Kelas ini mendominasi lebih dari 90\% spesies Spons. Sebagian Demospongiae dapat hidup pada daerah beriklim ekstrim, namun tidak dapat bertahan lama, meskipun ditemukan jenis spons ini dapat hidup sampai 200 tahun atau lebih. Beberapa kalsifikasi demosponges tumbuh dengan hanya $0,2 \mathrm{~mm}(0,0079$ in) per tahun. Beberapa spons jenis ini sudah memiliki alat reproduksi seksual dimana spons baru berumur beberapa minggu, sementara yang lain menunggu sampai beberapa tahun.

Kelas hexactinellida atau spons gelas yang hidup dilaut dalam dan tersebar luas dengan spikula terdiri dari silikat dan tidak mengandung sponging. Sebagian besar spesies spons memiliki kemampuan untuk melakukan gerakan-gerakan yang terkoordinasi di seluruh tubuh mereka, terutama kontraksi dari pinacocytes, dapat meremas saluran air sedimen dan peremasan ini dapat dikurangi termasuk pengeluaran zat lain yang menyebabkan penyumbatan. Beberapa spesies spons mengikat osculum secara independen dari sisa tubuh. Spons juga dapat berkontraksi untuk mengurangi area yang rentan terhadap serangan predator. Spons kaca mampu mengirim impuls listrik dengan cepat melalui seluruh bagian 
syncytium, dan menggunakannya untuk menghentikan gerakan flagela jika air yang masuk mengandung racun atau sedimen yang berlebihan.

Kelas Sclerospongia merupakan spons yang kebanyakan hidup pada perairan dalam di terumbu karang atau pada gua-gua, celah-celah batuan bawah laut atau terowongan terumbu karang. Semua jenis ini adalah tipe leuconoid yang kompleks dan mempunyai spikula silikat serta serat spongin. Elemen-elemen ini dikelilingi oleh jaringan hidup yang terdapat pada rangka basal kalsium karbonat yang kokoh atau pada rongga yang ditutupi oleh kalsium karbonat.

\section{4. Cara Hidup dan Habitat Spons}

Pergerakan spons dewasa secara fundamental menyerupai hewan. beberapa spesies spons laut dapat bergerak melintasi dasar laut dengan kecepatan 1 - 4 mm (0,039-0,16 inc) per hari, sebagai akibat dari amuba seperti gerakan pinacocytes dan sel lainnya. Beberapa spesies spons laut dapat bekerjasama dengan seluruh tubuh mereka, dapat menutup tubuh mereka dengan oscula dan ostia dan dapat berenang bebas.

Partikel terkecil disekitar spons kebanyakan dikonsumsi melalui choanocytes dan dapat menangkap $80 \%$ dari pasokan makanan spons. Spons menyaring partikel makanan dari air yang mengalir melalui tubuh mereka disebut pencernaan intraseluler, sehingga spons mendapat julukan sambal menyelam minum air. Partikel yang lebih besar dari $50 \mu \mathrm{m}$ tidak memungkinkan masuk dalam ostia dan pinacocytes, sedangkan partikel berukuran $0,5 \mu \mathrm{m}$ sampai $50 \mu \mathrm{m}$ akan terjebak dalam ostia spons. Partikel ini dikonsumsi oleh pinacocytes atau archaeocytes yang sebagian dikeluarkan melalui dinding ostia. Bakteri-partikel berukuran di bawah $0.5 \mu \mathrm{m}$, melewati ostia, ditangkap dan dikonsumsi oleh choanocytes. Spesies Archaeocytes mengangkut makanan yang dikemas dalam vesikula dari sel yang secara langsung mencerna makanan. Satu spesies spons memiliki serat internal yang berfungsi sebagai trek untuk digunakan sebagai nutrisi yang dibawah oleh archaeocytes.

Spons hidup secara heterotrof. Makanan spons adalah bakteri dan plankton. Makanan yang masuk ke tubuh spons dalam bentuk cairan sehingga porifera disebut hewan pemakan cairan. Pencernaan spons dijalankan intraseluler di dalam koanosit dan amoebosit Ukuran dan bentuk spons bervariasi, mulai dari mikroskopis hingga mencapai tinggi 2 
meter. Sedangkan bentuknya merambat, bercabang, tegak seperti cerobong atau pipa. Warna spons bervariasi, dari warna gelap hingga cerah. Warna pada Spons disebabkan oleh pigmen karotenoid. Spesies spons tertentu memiliki pigmen yang berwarna gelap setelah kontak dengan udara, ada spons yang mampu menghasilkan pigmen yang dapat menyebabkan iritasi pada kulit manusia.

Sel busa spons menyerap oksigen dengan berdifusi dari air ke dalam sel seperti air mengalir melalui tubuhnya, di mana karbon dioksida dan produk limbah lainnya contohnya ammonia akan larut. Archeocytes menghilangkan partikel mineral yang mengancam dengan memblokir ostia dan mengangkut mineral melalui mesohyl dan membuang mineral ke dalam air saat keluar, meskipun beberapa spesies menggabungkannya ke dalam kerangka mereka.

Reproduksi spons yang memiliki tiga aseksual yakni fragmentasi, dengan tunas, dan memproduksi gemmula. Fragmen spons dapat dilepaskan oleh arus atau gelombang atau pada istilah lainnya dikatakan bahwa cara reproduksi pada spons terbagi atas dua kategori, yaitu: ovipar dan vivipar. Kebanyakan ordo Astrophorida, Spirophorida, Hadromerida, Axinellida dari subkelas Tetractinomorpha cara reproduksinya tergolong ovipar, sedangkan ordo Homosclerophorida dari subkelas Homoscleromorpha, ordo Halichondrida, Poecilosclerida, Haplosclerida, Dictyoceratida, Dendroceratida dari subkelas Tetractinomorpha cara reproduksinya tergolong vivipar. Jenis spons yang ovipar, telur yang telah difertilisasi diletakkan di mesohyl, selanjutnya dikeluarkan dari tubuh spons kemudian menetas, sedangkan pada jenis spons yang vivipar, larva spons dikeluarkan dari tubuh spons dan berenang dengan bulu getarnya selama selang waktu tertentu sampai mendapat tempat menempel yang sesuai. Salah satu bentuk ovipar pada beberapa spons dari kelas Demospongiae, telur dan awal embrio tersimpan pada rangkaian gelatin yang melekat pada permukaan bagian terluar induk betina spons, perkembangan tahap larva parenchymula terjadi pada pembungkus lendir.

Sejumlah proses reproduksi aseksual pada spons terjadi secara alami, yang dasarnya pada potensi perkembangan archaecytes. Proses ini temasuk pembentukan pucuk (bud formation), penyembuhan luka (wound healing), pertumbuhan somatik (somatic growth), pembentukan gemmule (gemmule formation). Kebanyakan spons, baik yang hidup di laut maupun 
yang hidup di air tawar, mempunyai reproduksi aseksual yang unik, yaitu pembentukan gemmule. Proses perkembangan gemmule pada spons ini berbeda dengan spons air tawar. Thesocytes diperoleh dari Choanocytes yang mengalami perubahan ke dalam bentuk archaeocytes peralihan, dan bentuk vitellogenesis jelas kelihatan. Pada penambahan aktifitas sintesis archaecytes, cadangan senyawa diassimilasi melalui phagocytosis, pinocytosis dan terdapat pseudopodia berperekat atau batang sitoplasmaik antara thesocytes bagian depan dan nurse cellsGemmule mengandung kapsul spongin, spikula, dan dibungkus dengan archaeocytes yang mengandung cadangan makanan, seperti glycogen. Potongan-potongan spons yang patah dapat hidup dengan cadangan makanan yang ada ditubuhnya, kemudian beregenerasi membentuk tunas baru atau kompleks gemmule untuk menjadi spons dewasa.

Seksualitas pada spons dapat dikelompokkan atas dua tipe, yaitu: (1) Hermaprodit, yaitu jenis spons yang menghasilkan baik gamet jantan atau gamet betina selama hidupnya, tetapi menghasilkan gamet jantan dan gamet betina dalam satu waktu yang berbeda; (2) Gonokhorik, yaitu: jenis spons yang memproduksi hanya gamet jantan atau gamet betina saja selama hidupnya. Seksualitas bertipe gonokhorik, khususnya dari ordo Hadromerida didapatkan pada jenis Tethya crypta, Tethya auratum, Tethya citrina (Tethydae); Chondrosia reniformis, Chondrilla nuculai (Chondrosiidae); Polymastia hirsuta, Aaptos aaptos (Polymastiidae, Xestospongia berquistia dan Xestospongia. Selain itu didapatkan juga seksualitas bertipa gonokhorik labil (Labile gonochorism). Seksualitas bertipe seperti ini ditemukan pada spons jenis, Suberitas carnous (Hadromerida) dan Raspailia topsenti (Axinellida).

Spons hidup dan tumbuh dengan melekat atau menempel pada beberapa benda keras bawah laut seperti karang, bebatuan dan karang. Spons memiliki banyak perbedaan yang sangat beragam antara spesiesnya dalam hal ukuran, bentuk dan warna. Beberapa spons ada yang berukuran kecil sekecil butiran beras sampai berukuran besar dengan ukuran panjang lebih dari empat kaki. Dalam pertumbuhannya, bentuk luar spons sangat bervariasi. Bentuk luar ini dapat berupa tabung, pengebor, merambat, masive, jari, bola, semi bola, bercabang-cabang, tugu dan sebagainya. Bentuk luar spons laut sangat dipengaruhi oleh faktor fisik, kimiawi, dan biologis lingkungannya. Spesimen yang berada di lingkungan yang 
terbuka dan berombak besar cenderung pendek pertumbuhannya atau merambat. Sebaliknya spesimen dari jenis yang sama pada lingkungan yang terlindung atau perairan yang lebih dalam dan berarus tenang, pertumbuhannya cenderung tegak dan tinggi. Pada perairan yang lebih dalam spons cenderung memiliki tubuh yang lebih simetris dan lebih besar sebagai akibat lingkungan yang lebih stabil apabila dibandingkan dengan jenis yang sama, hidup pada perairan yang dangkal. Ukuran spons juga beragam, mulai dari jenis berukuran sebesar kepala jarum pentul, sampai jenis yang ukuran garis tengahnya $0.9 \mathrm{~m}$ dan tebalnya $30.5 \mathrm{~cm}$.

Jenis- jenis spons tertentu nampak berbulu getar karena spikulanya menyembul keluar dari badannya Selain dipengaruhi oleh faktor lingkungannya, morfologi spons juga dipengaruhi oleh predator, kompetisi, serta ketersediaan cahaya. Pada perairan yang kaya nutrien spons yang mengalami pertumbuhan yang lebih cepat, secara umum makin banyak kandungan partikel makanan di dalam air yang mengelilingi spons, makin cepat spons tumbuh. Laju pertumbuhan koloni spons dapat berbeda satu dengan lainnya, karena dipengaruhi oleh perbedaan spesies, umur dan koloni. Koloni yang kecil atau muda cenderung tumbuh lebih cepat dibandingkan koloni dengan pertumbuhan masive. Perbedaan kecepatan pertumbuhan diduga karena adanya perbedaan antara kerangka dan jaringan spons. Selain itu, ketersediaan energi awal yang terkandung dalam setiap potongan benih juga mempengaruhi kecepatan pertumbuhan. Adapun parameter-parameter kualitas perairan yang membatasi pertumbuhan spons antara lain cahaya, tingkat kecerahan, suhu, ombak, kekeruhan, sedimentasi dan kecepatan arus yang juga memberikan pengaruh terhadap pertumbuhan spons.

Spons menggunakan mobilitas pinacocytes dan choanocytes dan membentuk kembali dari mesohyl untuk kembali melekatkan diri pada permukaan yang cocok dan kemudian membangun kembali diri mereka sebagai spons kecil, namun hanya berupa fungsional selama beberapa hari. Fragmen spons hanya dapat diregenerasi jika mengandung collencytes untuk menghasilkan mesohyl dan archeocytes untuk menghasilkan semua jenis sel lainnya. Spesies spons laut sangat sedikit berkembang biak dengan tunas. Gemmula adalah polong hidup. Gemmula diproduksi oleh ribuan spons spesies air tawar saat spons tersebut terancam. Gemmula dihasilkan secara teratur pada musim gugur. Spongocytes membuat 
gemmules dengan membungkus cangkang spongin, sering diperkuat dengan spikula, cluster putaran dari archeocytes yang penuh nutrisi, gemmula spons air tawar dapat mencakup simbion phytosynthesizing, gemmula kemudian menjadi aktif, dan dapat bertahan dalam cuaca dingin, panas, kekurangan oksigen dan variasi ekstrim dalam salinitas.

Pencernaan terjadi secara intraseluler seperti pada protozoa dan hasilnya disimpan dalam organ archeocyte. Selain menyaring partikel, di dalam tubuh spons juga terjadi pertukaran gas secara difusi. Spons tidak memiliki sistem saraf sehingga pergerakannya bergantung pada arus air.

\section{5. Keunikan Spons (Karakter dan corak)}

Spons menempati cabang tertua dan terendah dalam pohon keluarga binatang, Hal ini telah membuat beberapa orang berspekulasi bahwa spons purba berevolusi menjadi binatang dan manusia. Sebuah tayangan dokumenter di televisi bahkan menyebut-nyebut spons sebagai "Hawa-nya binatang" atau leluhur yang menjadi cikal bakal lahirnya manusia.

Upaya analisis tetntang spons dalam bidang sains untuk menjawab pertanyaan, Apakah spons sekadar makhluk sederhana, atau spons terbukti sebagai suatu sosok hasil rancangan arsitektur yang unik, mengapa, karena spons tidak berjantung, dan tidak berotak serta tanpa jaringan syaraf, dan bentuk tampak seperti tanaman. Pandangan Aristoteles dan Plinius Tua, dengan yakin menyebut spons sebagai binatang. Para pakar memperkirakan ada sekurang-kurangnya 15.000 spesies spons yang hidup di seluruh danau serta samudra dunia, dan memiliki beraneka ragam bentuk dan warna yang memukau. Ada spons yang bentuknya seperti jari yang langsing, tong yang gendut, karpet yang terhampar, kipas yang anggun, dan bahkan bentuk vas kristal yang halus dan masih banyak lagi. Ada yang lebih kecil daripada sebutir beras, dan ada yang lebih tinggi daripada manusia. Para ilmuwan yakin bahwa beberapa spons sudah ratusan tahun usianya.

Tinjaun struktur, fungsi, dan perkembangan, spons sangat berbeda dengan binatang lain, karena spons tidak memiliki organ tubuh bagian dalam. .Sel-sel yang sangat kecil di dalam spons menjalankan banyak fungsi yang menunjang kehidupan. Ada sel-sel khusus untuk menangkap makanan, untuk mengangkut zat gizi, atau untuk membuang kotoran. 
Bagian yang lain bekerja keras membangun komponen tulang atau kulit. Ada sel yang bahkan bisa berubah dari satu jenis sel menjadi jenis lain seandainya dibutuhkan.

Keunikan lain yang dimiliki spons adalah sel-selnya berkelompok sama seperti susunan sel semula meskipun telah dilumatkan. Jika spons digiling, tampak sel-selnya terpisah perlahan-lahan membentuk dua sel binatang memnyerupai susunan semula, sehingga spons dikatakan dapat membangkitkan dirinya sendiri. Fenomena spons ini tidak dimiliki oleh tanaman atau binatang lain. Spons juga bisa berkembang biak dengan luar biasa lentuk. Ada spons yang meluncurkan sel-sel bagaikan pesawat ruang angkasa untuk mengkolonisasi tempat lain. Sel-sel ini mengadakan perjalanan dalam keadaan mati suri hingga akhirnya mendarat, terbangun, dan menghasilkan spons baru. Spons jenis lain, ada yang berkembang biak secara seksual, dan setiap spons bisa berganti peran menjadi jantan atau betina menurut kebutuhan. Ada juga spons yang bertelur. Semakin dicermati, semakin banyak kerumitan yang kita lihat pada diri spons.

Spons memiliki sistem makan yang unik di antara binatang lainnya. Pori-pori yang sangat kecil di kulit luarnya mengarah ke jaringan terowongan dan ruangan yang sangat rumit di seluruh bagian dalam spons. Jutaan sel pendayung yang sangat kecil, atau koanosit, melapisi dinding terowongan dan ruangan. Setiap sel memiliki sehelai benang seperti cambuk yang menyentak ke depan dan ke belakang, menyerupaia para pendayung dalam mendayung perahu. Sel-sel ini berfungsi untuk mendorong arus air secara teratur melewati sel-sel lain dalam spons itu, yang dirancang untuk menangkap dan mencerna partikel makanan dalam air. Aliran makanan dan air yang terus-menerus melewati spons menjadikannya rumah yang ideal untuk udang, kepiting, dan makhluk mungil lain. Ada spons yang bersimbion oleh 17.128 makhluk lain. Sejumlah besar bakteri, alga, dan fungi menikmati hubungan kerjasama, atau simbiosis, dengan spons. Bakteri bisa mencapai 50 persen berat basah sebuah spons.

Banyak pandangan bahwa spons dan penghuninya berpotensi menjadi sumber obat-obatan baru yang unik. Ada yang percaya bahwa obat-obat tersebut bisa memerangi AIDS, kanker, malaria, dan penyakit lain. Setelah meninjau banyak fitur biologi yang spektakuler pada spons, dapat disimpulkan bahwa spons yang sederhana itu adalah jenis binatang 
yang sangat rumit, bahkan belum dipahami sepenuhnya hingga Kini. Kerumitan spons tersebut membuat kita bertanya: Bagaimana, mengapa dan untuk apa binatang serumit ini ada. Apakah spons terjadi secara kebetulan ataukah apakah spons sebagai pembuktian nyata tentang keberadaan Sang Pencipta yang cerdas?

Meskipun beberapa orang mungkin tidak mau memikirkan keberadaan Pencipta, namun banyak orang sependapat dengan kesimpulan bahwa dahulu kala; "Betapa banyak pekerjaanmu, oh, Sang Khalik, semuanya itu kaubuat dengan hikmat. Bumi penuh dengan hasil kerjamu, dimana berseliweran makhluk-makhluk hidup kecil maupun besar.

Bicara tentang spons laut, benak ini langsung tertuju pada makhluk kuning berbentuk kotak yang tinggal di rumah nanas di Bikini Bottom, Samudra Pasifik. Polahnya yang konyol dengan senyum lebar, mata besar, plus dukungan karibnya si bintang laut merah muda serta seluruh warga Bikini Bottom, menjadikan film ini sukses digandrungi jutaan pecinta animasi dari anak-anak hingga paruh baya. Spongebob the Squarepants yang pertama kali digagas pada 1996 oleh Stephen Hillenburg, seorang ahli biologi laut Universitas Humboldt California, dan sangat boleh jadi merupakan film animasi paling berhasil mengangkat kisah kehidupan bawah laut menjadi cerita yang disuka anak-anak dan juga dewasa.

Namun, kisah si "spongebob" di kehidupan nyata tak seglamor filmnya. Makhluk ini sejatinya hidup menetap dan berdiam di perairan, menyaring air yang keluar masuk melalui tubuhnya untuk mendapatkan partikel makanan yang terbawa air secara maksimal selama 24 jam setiap hari. Kespektakuleran spons mulai terusik dengan hadirnya maha karya manusia untuk memenuhi kebutuhan hidupnya dengan menggulirkan megaproyek yang namanya "reklamasi".

Reklamasi yang dilakukan oleh banyak orang diberbagai belahan dunia patut menjadi kekuatiran kita semua karena ini berdampak besar pada tercitnya system kesetimbangan baru terhadap biota laut dan lingkungan perairan laut itu sendiri. Kesetimbangan baru yang terjadi memaksa biota laut untuk dapat beradaptasi agar mampu hidup dengan kondisi lingkungan baru tersebut. Efek reklamasi pantai, berdampak luarbiasa terasa pada pola siklus sulfhur, siklus planton-fitoplanton, moluska dan tanpa kecuali spons. 


\section{6. Struktur Spons}

Secara umum struktur spons tersusun atas Osculum, mesohyl, spongocoal, Choanocyt, Amoebocyt, dan Spicula; dimana struktur spons tersebut dilengkapi dengan saluran aliran air dan terlihat bahwa tubuh spons memiliki porositas yang menjamin spons sebagai hewan filter feeder. Bagian dari tubuh spons tersebut di bungkus oleh Epidermis. Sistem pencernaan spons terdiri atas bagian yang dapat mendeaktifasi zat racun pada system nutrisi yakni Phagocytosis dan juga memiliki perut atau kantong makanan, dilengkapi dengan Flagella. Lebih lengkap perhatikan Gambar 1.1. berikut:

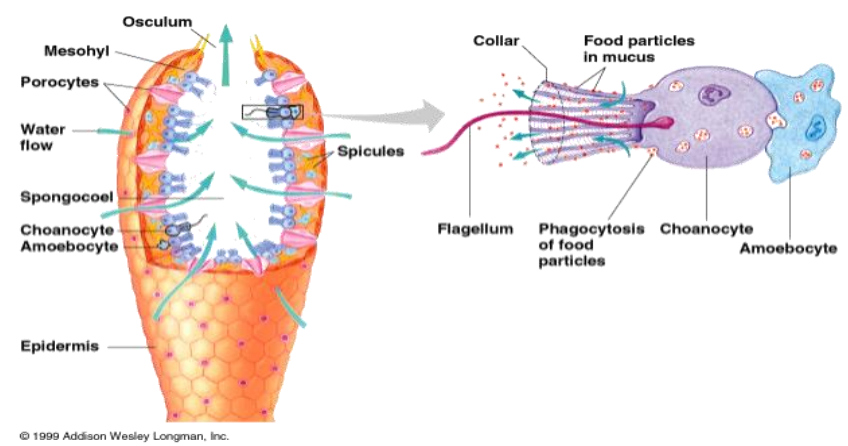

Gambar 1. 1. Struktur Spons secara Umum

Gambar 1.1, memperlihatkan struktur spons secara umum, artinya bagian-bagian penyusun tubuh spons relatif dimiliki oleh setiap jenis spons. Bagian yang pentingan dalam tubuh spons seperti Osculum, mesohyl, Choanocyta, Amoebocyta dan spicula dan saluran air. Setiap bagian yang menyusun tubuh spons memiliki fungsi masing-masing yang dijalankan untuk mendukung pertumbuhan dan perkembangan spons sebagai salah satu hewan laut dengan memperoleh makanan cara filter feeder.
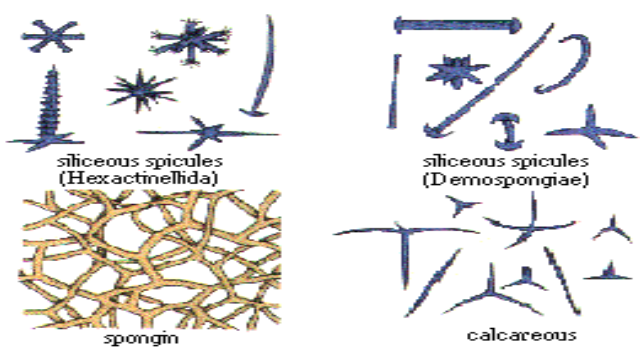

Gambar 1. 2. Struktur Spons secara Umum

Mengenal Spons Indonesia [15] 
Gambar 1.2, memperlihatkan susunan spons atau bentuk tubuh spons, dimana dari tiga kelas golongan spons yang ada, memperlihatkan bentuk tubuh spons yang berbeda antara setiap kelas dengan ciri masingmasing, mulai dari kelas Demospongia, Calcarea, Hexatinellida dan kelas keempat adalah Sclerospongia. Struktur spons tersebut memiliki ciri khas antara satu kelas spons dengan kelas spons lainnya. kelas Demospongia memperlihatkan bentuk seperti bintang dan culab sabit sementara kelas Calcarea Nampak seperti jangkar dan Hexatinellida seperti bitang berekor. Struktur spons seperti tersebut di atas merupakan salah satu dari sekian banyak keunikan dari spons. 


\section{Bab -2-}

\section{FISIOLOGI, ANATOMI, MORFOLOGI DAN HISTOLOGI SPONS}

\section{1. Fisiologi Spons}

Bentuk tubuh spons sederhana seperti tabung dengan dinding tipis, atau bentuknya ada yang masif, kurang teratur dan beragam. Beberapa jenis spons bercabang menyerupai pohon, lainnya berbentuk seperti sarung tinju, ada yang seperti cawan, seperti kubah. Ukuran spons juga beragam, mulai dari jenis berukuran sebesar kepala jarum pentul, sampai ke jenis yang ukuran garis tengahnya $0,9 \mathrm{~m}$ dan tebalnya $30,5 \mathrm{~cm}$. Jenisjenis spons tertentu nampak berbulu getar karena spikulanya menyembul keluar dari badannya.

Spons mengandung gen hanya diaktifkan di sel termos yang muncul hanya dalam larva dan dapat memberikan beberapa kemampuan sensorik. Hal ini menunjukkan bahwa sel termos merupakan bagian deteksi awal dari neuron yang merupakan bukti bahwa nenek moyang spons memiliki neuron. Neuron dapat hilang karena menyesuaikan dengan model hidup sessil.

Spons tidak memiliki sistem kekebalan tubuh yang kompleks. Beberapa spesies spons laut memiliki sel yang berperan dalam penolakan benda asing, dengan menghasilkan zat kimia digunakan untuk menghentikan pergerakan sel lain di daerah tertentu, sehingga mencegah penyusupan benda asing menggunakan sistem internalnya. Jika gangguan tersebut berlanjut, sel berakumulasi dan berkonsentrasi di daerah dan melepaskan racun untuk membunuh semua sel, selanjutnya system kekebalan spons diaktifkan dalam 4 (empat) minggu.

Penyebaran spons secara umum pada daerah kutub ke daerah tropis. Kebanyakan berada pada air tenang, air jernih, jika sedimen teraduk oleh gelombang atau arus, berakibat terblokirnya pori-pori spons, akibatnya, spons tersebut sulit untuk mendapatkan makanan dan bernapas. Jumlah terbesar spons biasanya ditemukan pada permukaan tumpukan seperti batu, karang, tetapi beberapa spons dapat melekatkan diri pada sedimen lunak melalui basis akar. Pengamatan tentang pengaruh sedimen (Kekeruhan) terhadap perkembangan spon dilakukan pada area sebaran di 
sekitar Pantai Melawai Balik Papang, Kalimantan Timur dan pada area Kepulauan Spermonde Sulawesi Selatan, khususnya pulau Barrang Caddi, Kodingareng Keke, Barang Lompo, Pulau Kapoposang, Pulau Langkai dan lainnya.

Spons dapat menghasilkan zat kimia, kecuali spons kaca untuk pertahanan terhadap predator. Toksisitas zat kimia yang dihasilkan spons tidak mengganggu keberadaan ikan disekitarnya, bahkan predasi ikan dapat membantu menyebarkan spons. Spons di kehidupan nyata memiliki bentuk dan warna yang sangat bervariasi. Dari sebesar kacang hingga setinggi satu meter, berbentuk simetri radial dan jambangan, namun sebagian besar tidak beraturan dengan pola yang bermacam-macam. Umumnya berbentuk mengkuti sistem aliran air.

Banyak spons yang memiliki alat reproduksi ganda, namun sangat sulit membedakan spons jantan dan betina, meskipun sebagian spons memiliki identitas kelamin yang jelas antara jantan dan betina (dioecious), namun kebanyakan spons adalah hermafrodit atau berkelamin ganda. Spons hermafrodit memproduksi sel telur dan sel sperma pada waktu yang berbeda. Metode ini, spons dapat berkembang biak secara seksual di antara komunitas spons dalam habitatnya. Perkembangbiakan secara aseksual juga dapat dilakukan oleh spons dengan cara membuat tunas internal (gemmules) yang dibentuk dari archeocyte dan cadangan makanan. Tunas yang terbentuk merupakan duplikat dari indunknya, selanjutnya secara berlahan melepaskan diri dari induknya untuk membentuk pola kehidupan mandiri. Pelepasan tunas dari induknya umumnya terjadi pada musim semi atau kondisi habitat spons dalam keadaan kondusif.

Kemampuan regenerasi spons sangat tinggi. Jika sebagian tubuh spons terpotong, rusak atau hancur, bagian tersebut dapat beregenerasi menjadi bagian yang utuh kembali seperti semula. Agar dapat melakukan regenerasi, bagian tubuh yang masih sehat tidak boleh kurang dari $0.4 \mathrm{~mm}$ dan masih mengandung sel-sel koanosit dalam jumlah mencukupi untuk menumbuhkan bagian spons yang baru. Penyu sisik, bintang laut dan beberapa jenis nudibranchia (siput laut) merupakan predator terhadap spons, sehingga spons harus bekerja ekstra keras untuk lebih cepat beregenerasi dan berkembang biak jika di lingkungan sekitarnya terdapat ketiga jenis makhluk ini.

Fisiologi, Anatomi, Morfologi dan Histologi Spons [18] 
Fisiologi spons contohnya seperti Spongia sp memiliki tinggi 10 $\mathrm{cm}$ dan diameter $1 \mathrm{~cm}$, bentuk bulat masif menyerupai mangkuk, serta mempunyai tipe sel Leuconoid/Rhagon yang rumit dan kompleks. Warna tubuhnya putih keruh coklat dan ada juga yang berwarna kuning atau orange. Bagian ujung spons yang bercabang dapat ditemukan oskulum (tunggal: oskula) sebagai saluran keluarnya air dari dalam tubuh spons dan di daerah badannya terdapat ostium (tunggal: ostia) sebagai saluran masuknya air. Spongia sp tidak mempunyai spikula maupun mengandung silika. Serabut-serabut spongin (keras = tanduk) berfungsi sebagai pendukungan dalam menjaga dan mencega pori-pori spons terbuka.

\section{1. 1. Fisiologi Bentuk dan Permukaan Tubuh}

\section{a. Petrosia (Strongylophora) corticata - Petrosiidae}

Spongioblast dan pembentukan sponging (gambar 1), dan pembentukan spongin (kanan) Spongia sp banyak ditemukan di lautan yang kedalamannya mencapai 50 meter dari dasar laut, umumnya hidup menempel pada substrat dasar pantai berupa bebatuan, cangkang, koral dari karang. Beberapa contoh spesies dari genus Spongia dan penyebarannya: Spongia tubulifera fouled

Berbentuk seperti bola besar dan lunak, tought serta bersifat masif. Warna kulit hitam, tetapi tampaknya ada yang sangat mengotori di antara oscules tersebar, yang bisa diangkat sebagai cerobong asap, mereka berakhir dengan kerah berbentuk kerucut. Interior krem putih. Mirip dengan kerangka Spongia obscura smooth, tapi lebih tebal dari Spongia obscura shaggy.

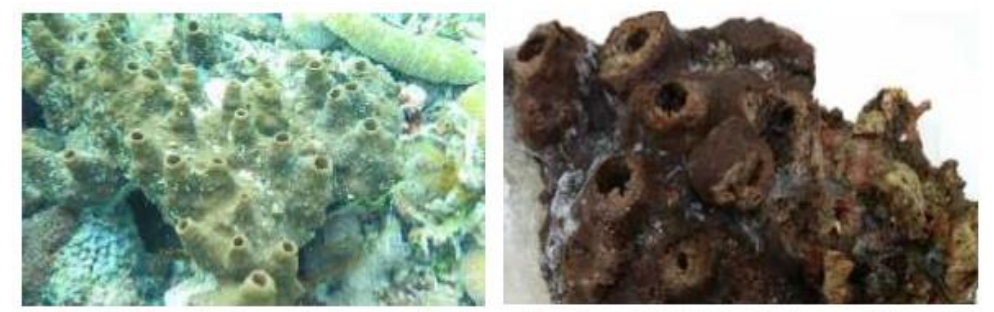

Gambar 2. 1. Petrosia (Strongylophora) corticata Petrosiidae diperoleh dari Pulau Kodingareng Keke: (a) Foto spons dalam laut, (b) Pengambilan Gambar di Permukaan setelah di Frezeerselama 2 hari; Referensi: Wilson, 1925; Sumber: Data Primer 


\section{b. Niphates sp.- Niphatidae}

Terlihat berwarna hitam dan besar, membentuk gundukan lateral pipih atau bulat. Bersifat lobate dan masif. Diratakan yang dengan oscules berjajar dalam puncak yang bulat dengan oscules tersebar. Oscules dengan kerah berbentuk kerucut. Shaggy dengan ujung serat permukaan. Interior bata merah. Spongin lebih tipis daripada di Spongia lain dari panduan serat ini, dalam retikulasi lebih dikemas.
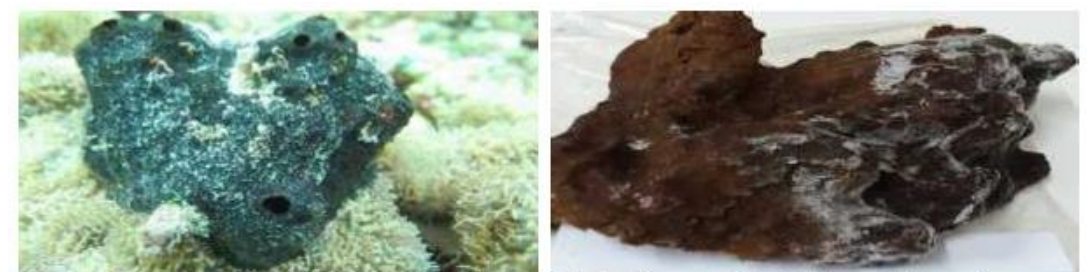

Gambar 2. 2. Niphates sp.- Niphatidae, diperoleh dari Pulau Kodingareng Keke (a) Pengambilan gambar spons dalam laut, (b) Pengambilan gambar setelah 2 hari di dalam Frezeer/permukaan di permukaa; Referensi: Duchassaing \& Michelotti, 1864, Sumber: Data Primer

\section{c. Hyrtios erectus - Thorectidae}

Berwarna hitam dan besar, membentuk gundukan lateral pipih atau bulat. Bersifat lobate dan masif. Membentuk gundukan halus, seringkali cukup bulat tapi terdapat lateral yang diperluas. Bersifat masif dan merayap. Oscules tersebar atau sejajar, dengan kerah berbentuk kerucut. Interior warna krem. Kerangkanya lebih tebal dari Spongia obscura shaggy.

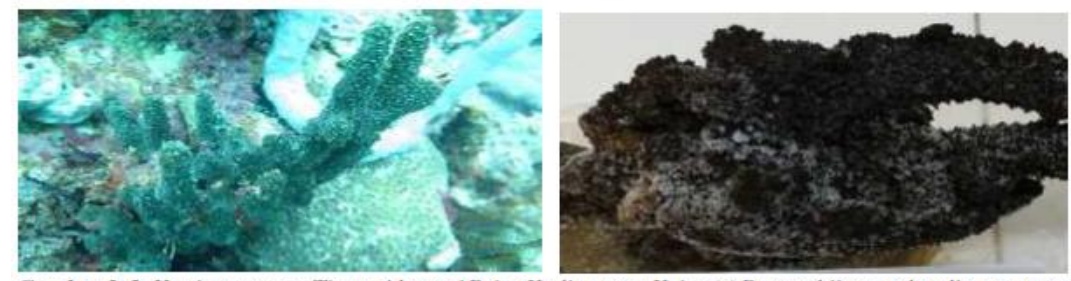

Gambar 2. 3. Hyrtios erectus - Thorectidae asal Pulau Kodingareng Keke, (a) Pengambilan gambar dimana spons dalam laut, (b) Pengambilan gambar setelah bebebrapa 2 hari di dalam Frezer/ permukaa; Referensi: Keller, 1889 ; Sumber: Data Primer

\section{d. Clathria (Clathria) basilana}

Merupakan salah jenis spons kelas Demospongiae adalah. Spesies ini juga merupakan bagian dari genus Clathria dan famili Microcionidae. Nama ilmiah spesies ini pertama kali diterbitkan pada tahun 1961 oleh Lévi. Seperti spons pada umumnya, spesies ini memiliki tubuh yang 
berpori dan permukaan yang keras seperti batu. Selain itu, Clathria (Clathria) basilana juga dapat menyerap oksigen dari air melalui proses difusi.
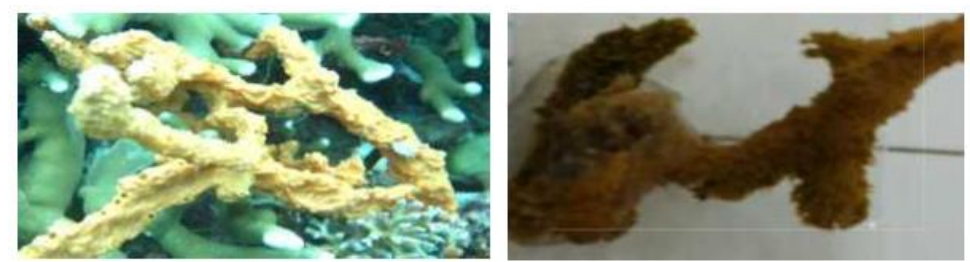

Gambar 2. 4. Clathria (Clathria) basilana asal Pulau Kodingareng Keke, (a) Pengambilan gambar dalam laut, (b) Pengambilan gambar setelah bebebrapa 2 hari di dalam Frezer/ permukaa; Referensi: Keller, 1889; Sumber: Data Primer

\section{d. Callyspongia - Cladochalina - glomerata}

Spesies spons yang tergolong dalam kelas Demospongiae. Spesies ini juga merupakan bagian dari genus Callyspongia dan family Callyspongiidae. Nama ilmiah spesies ini pertama kali diterbitkan pada tahun 1897 oleh Whitelegge. Seperti spons pada umumnya berwarna coklat kekuningan, spesies ini memiliki tubuh yang berpori dan permukaan yang keras seperti batu. Selain itu, Callyspongia (Cladochalina) glomerata juga dapat menyerap oksigen dari air melalui proses difusi.

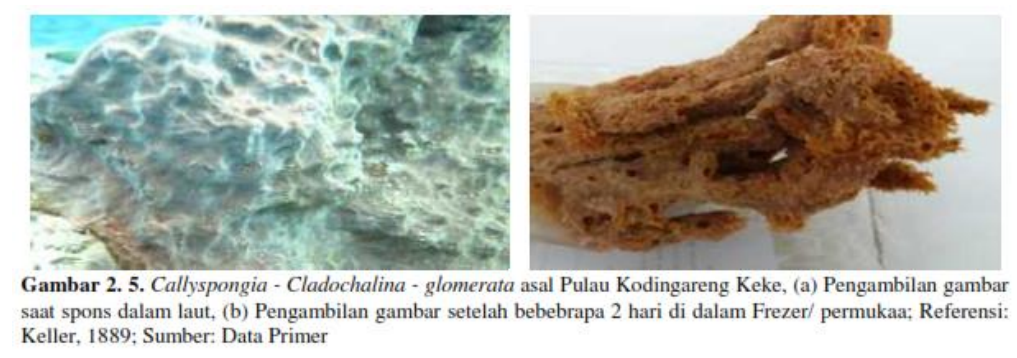

e. Azulleta $s p$ - Axinellidae

Auletta $s p$ salah satu jenis spons yang belum diketahui jenisnya, yang aktif terhadap bakteri Staphylococcus aures, Bacillussubtilis dan Vibrio cholerae Eltor. (Rachmaniar, 1996). Spesies dari Axinella ada di Samudra Hindia dan Pasifik. Kebanyakan dari spons ini lebih kecil dari $20 \mathrm{~cm}$, dan berwarna kuning atau oranye. 

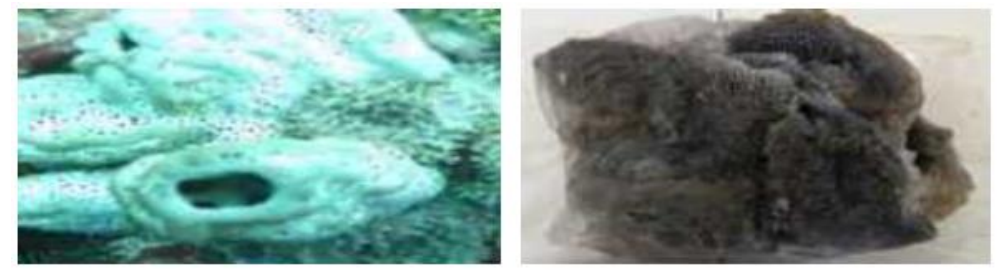

Gambar 2. 6. Auletta sp asal Pulau Kodingareng Keke, (a) Pengambilan gambar saat spons masih dalam laut, (b) Pengambilan gambar setelah bebebrapa 2 hari di dalam Frezer/ permukaa; Referensi: Keller, 1889; Sumber: Data Primer

\section{f. Neopetrosia sp}

Salah satu jenis spons dengan julukan spon biru cerah sampai orang kekuningan. Pertumbuhan hanya mencapai sekitar 6-10 cm/tahun terkadang lebih besar. Secara umum encrusting, dengan tombol kecil (diameter $5 \mathrm{~cm}$ ) dan tonjolan di seluruh. Setiap tombol atau gumpalan memiliki lubang besar di ujung dengan bibir membran yang sempit, terlihat ketika spons terendam. Teksturnya agak kasar. Biasanya biru elektrik. Makanan favorit dari Polka-dot nudibranch (Jorunna funebris) dan nudibranch.
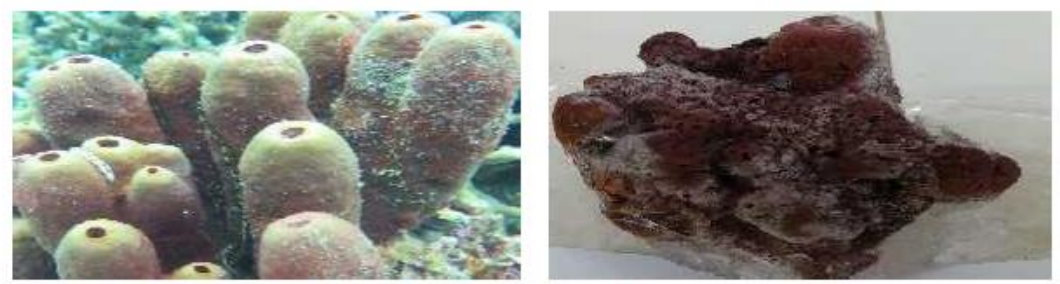

Gambar 2. 7. Neopetrosia sp asal Pulau Kodingareng Keke, (a) Pengambilan gambar saat spons dalam laut, (b) Pengambilan gambar setelah bebebrapa 2 hari di dalam Frezer/ permukaa; Referensi: Keller, 1889; Sumber: Data Primer

\section{h. Callyspongia aerizusa}

Callyspongia (Cladochalina) aerizusa adalah spesies spons yang tergolong dalam kelas Demospongiae. Spesies ini juga merupakan bagian dari genus Callyspongia dan famili Callyspongiidae. Nama ilmiah spesies ini pertama kali diterbitkan pada tahun 1984 oleh Desqueyroux-Faúndez. Seperti spons pada umumnya, spesies ini memiliki tubuh yang berpori dan permukaan yang keras seperti batu. Selain itu, Callyspongia (Cladochalina) aerizusa juga dapat menyerap oksigen dari air melalui proses difusi. 

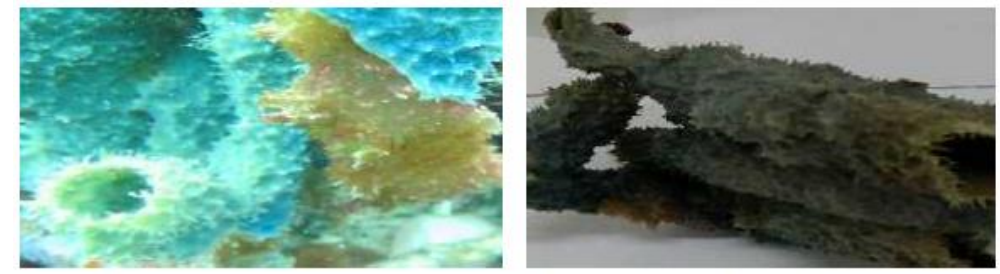

Gambar 2. 8. Callyspongia (Cladochalina) aerizusa asal Pulau Kodingareng Keke, (a) Pengambilan gambar saat spons masih dalam laut, (b) Pengambilan gambar setelah bebebrapa 2 hari di dalam Frezer/ permukaa; Referensi: Keller, 1889; Sumber: Data Primer

\section{1. 2. Fisiologi pencernaan dan ekskresi}

Beberapa jenis spons pemakan suspensi, metode makan tersebut dikenal dengan cara menyaring makanan (filter feeder). Spons memperoleh makanan dalam bentuk partikel organik renik, hidup atau tidak, seperti bakteri, mikroalga dan detritus, yang masuk melalui poripori saluran masuk yang terbuka dalam air lalu dibawa kedalam rongga atau ruang bercambuk (Flagella) terjadi di choanocyt. Air mengalir melalui ostia kedalam paragaster, sehingga dapat dikatakan bahwa air disaring melalui ostia tersebut. Paragester adalah suatu rongga didalam tubuh spons dimana air dapat masuk kedalamnya, kemudian mengalir keluar melalui osculum.

Air ini melalui lubang di dalam porocyt. Lubang ini menutup, bila myocyt yang mengelilingi porocyt mengkerut. Myocyt ialah cel-cel otot. Material yang masuk ikut dengan adalah benda-benda organik dan jasadjasad yang kecil. Koanosit memakan partikel makanan, baik disebelah maupun didalam sel leher. Gerakan proto plasma dari collare, selanjutnya diangkut ke pangkal collare pada dataran cel, lalu dimasukkan kedalam suatu vacuola. Di dalam vacuola, benda-benda organik tersebut di cerna, sehingga dapat dikatakan bahwa spons memiliki pencernaan intra celluler. Proses selanjutnya adalah makanan diteruskan ke amebocyt-amebocyt untuk proses cerna selanjutnya. Makanan yang telah dicerna disimpan didalam ameobocyt sebagai lemak, karbohidrat dan protein. Ameobocytameobocyt mengangkut makanan ke sel-sel lain. Dapat dikatakan bahwa spons hanya melakukan pergerakan atau perputaran air dalam tubuhnya untuk melakukan pencernaan dan ekskresi. Spons tidak mempunyai mulut, rongga pencernaan dan sistem ekskresi seperti yang terdapat pada hewan tingkat tinggi. 
Sisa makanan yang tidak dicerna dibuang keluar dari dalam sel leher. Makanan itu dipindahkan dari satu sel ke sel lain dan diedarkan dalam batas tertentu oleh sel-sel amoeba yang menyebar di lapisan tengah. Proses tersebut menyebabkan spons umumnya hidup dalam air bersikulasi, karennya sering kita temukan spons didalam air jernih. Arus air yang lewat melalui saluran sepon membawa serta zat buangan dari tubuh spons. Agar air yang keluar melalui oskulum dibuang jauh dari badan spons, karena sisa makanan ini mengandung asam karbon dan sampah nitrogen yang beracun bagi spons itu sendiri.

\section{1. 3. Fisiologi pernafasan}

Spons melakukan respirasi secara aerobik biasa, yaitu melalui difusi oleh sel-sel individu dalam tubuh spons tersebut. Biasanya spons tidak dapat bertahan jika kekurangan oksigen dalam air atau hidup pada air yang tercemar atau berbau. Oksigen yang dikonsumsi dalam waktu tertentu tergantung pada tingkat arus air. Bagian yang terhubung dengan ostium (tempat masuknya air) mengandung oksigen dapat mencapai $10 \%$ hingga $50 \%$ dari seluruh oksigen, cenderung mengkonsumsi lebih banyak jika dibandingkan dengan bagian-bagian spons lainnya.

\section{1. 4. Fisiologi saraf}

Spons yang telah diidentifikasi saat ini dinyatakan tidak memiliki system dan sel-sel saraf untuk mengkoordinasikan fungsi tubuh. Kebanyakan reaksi yang terjadi pada spons berasal dari hasil reaksi sel individu-individu dalam menanggapi stimulus dan ransangan sebagai bentuk respon tubuh terhadap dinamika internal dan sekternal tubuhnya. Sebagai contoh, sirkulasi air melalui beberapa spons adalah minimal saat matahari terbit dan maksimum sesaat sebelum matahari terbenam karena munculnya cahaya mengakibatkan penyempitan sel porocyte, ostia, dan sekitarnya. Untuk mengatasi hal tersebut spons menjaga kanal incurrentnya agar tetap terbuka. Reaksi lain menunjukkan beberapa komunikasi antar sel. Sebagai contoh, laju sirkulasi air melalui spons bisa berhenti tiba-tiba tanpa penyebab eksternal yang jelas. Reaksi tersebut dapat disebabkan hanya karena aktivitas choanocyte berhenti kurang lebih secara bersamaan menyiratkan beberapa bentuk komunikasi internal adalah unknow. Pesan kimia yang disampaikan oleh sel amoeboid dan 
gerakan ion di atas permukaan sel munkin merupakan mekanisme kontrol. Tubuh spons hanya menunjukkan sedikit kemampuan dalam menanggapi rangsangan (conduktivitas). Kemampuan yang paling kuat dalam menanggapi rangsang pada bagian tubuh spons, adalah di daerah osculu.

\section{1. 5. Fisiologi Osmoregulasi}

Fisiologi Osmoregulasi adalah peristiwa osmotik dan regulasi ion agar terjadi kesimbangan antara tubuh dan lingkungan. Organ osmoregulasi terdiri atas ginjal, insang, dan usus. Regulasi isotonik atau Isoosmotik, yaitu bila pada spons memiliki konsentrasi cairan tubuh sama dengan konsentrasi media, sehingga dapat dikatakan mereka tidak melakukan osmosis atau dalam keadaan kesetimbangan akibanyaknya tidak melakukan gerakan osmosis, yang terhjadi hanya gerakan ion dalam ukuran terbatas.

\section{2. Anatomi}

\section{2. 1. Anatomi Spons}

Dinding tubuh spons, termasuk kelas Demospongia pada genus spongia sp terdiri dari tiga lapis, dari luar ke dalam sebagai berikut: Pinacoderm, merupakan sel yang tersusun berupa sel pipih (pinacocyte). Pinacodem berfungsi untuk melindungi bagian dalam tubuh. Sel ini tidak mempunyai membran basalis. Bagian sel pinacocyte dapat berkontraksi atau berkerut, sehingga seluruh tubuhnya dapat membesar dan mengecil dalam range terbatas. Basal Pinacocyte mensekresi zat yang dapat melekatkan hewan ke substrat. Tubuh Spongia sp memiliki banyak poripori yang merupakan awal dari system kanal (saluran air) yang menghubungkan lingkungan eksternal dengan lingkungan internal. Tubuh porifera tidak dilengkapi dengan apendiks dan bagian tubuh yang dapat digerakkan. Tubuh porifera belum memiliki saluran pencernaan makanan, adapun pencernannya berlangsung secara intraseluler. Mereka memiliki ostia kecil. Ostia menyebabkan kanal incurrent banyak, tetapi tidak ada rongga sentral besar.

Pori-pori terbentuk oleh sel porocyte yang bentuknya seperti tabung pendek yang menghubungkan bagian luar dan spongocoel. Porocyte ditutupi di dalam porosopyle dan sangat bersifat kontraktil. Memiliki lumen berupa tabung yang merupakan fungsi ostium. Memiliki 
mesohyl (mesoglea) yang terdiri atas zat semacam agar (glatinous protein matrix) mengandung bahan tulang dan amoebocyte. Sel amoebocyte ini mempunyai banyak fungsi antara lain untuk mengangkut cadangan makanan, membuang partikel sisa metabolisme, membuat spikula, serat spons dan membuat sel reproduktif. Terdapat archaeocyte yang mampu membentuk sel tipe lainnya yang diperlukan sesuai kondisi.

Archaeocyte memiliki pseudopodia dan nukleus besar. Sel-sel tersebut memiliki hubungan dengan sistem nutrisi makanan dan ekskresi dan kadang-kadang dapat berperilaku sebagai sel kelamin. Amoebocyte untuk pengangkutan makanan dan tersebar di dalam mesohyle disebut amoebocyte pemangsa. Amoebocyte yang menetap dan mempunyai pseudopodia seperti benang, berfungsi sebagai jaringan pengikat biasa disebut collenocyte yang terdiri atas pseudopodia bercabang. Sel-sel ini tidak bermassa syncytial. Pseudopodia bercabang ini membentuk jaringan sterstruktur. Amoebocyte yang menghasilkan spikula dan serat spons disebut sclerocyte.

Choanocyte yang melapisi rongga spongocoel. Bentuk choanocyte yang lonjong dengan ujung satu melekat pada mesohyl dan ujung lainnya berada di spongocoel serta dilengkapi dengan sebuah flagelum yang dikelilingi kelopak dari fibril. Getaran flagel pada lapisan ini menghasilkan arus air di dalam spongocoel ke arah osculum, sementara fibril berfungsi sebagai alat penangkap makanan.

Sistem aliran tubuhnya adalah Leuconoid. Tubuh tipe ini memperlihatkan lipatan - lipatan dinding spongocoel yang rumit. Lipatan sebelah dalam menghasilkan sejumlah besar kantung yang dilapisi choanocyte yang disebut flagellated canal yang kemudian melipat lagi membentuk rongga kecil berflagella yang disebut flagellated chamber atau choanosyte chamber. Spongocoel menghilang dan digantikan oleh saluran - saluran kecil menuju oskulum. Dengan banyaknya lipatan berturut turut menyebabkan bentuk spons tidak beraturan (masif). Pada permukaannya ditutupi oleh epidermal epitelium yang dihasilkan oleh epidermal pores dan osculum. Dermal pores tersebut memimpin incurrent canal. Sub dermal dan incurrent canal memimpin flagellated chamber kecil oleh prosopyles. Flagellated chambers membuka incurrent canal melalui apopyles yang berupa tabung besar. Tipe sistem canal ini dibagai menjadi 3 subtipe, yaitu: 
1. Eurypylous: apopyles yang membuka langsung ke kanal excurrent melalui mulut lebar. Hal ini hadir dalam Plakina. Kursus arus air adalah seperti di bawah.

2. Aphodal: kanal sempit yang disebut aphodus hadir antara ruang flagellated dan kanal excurrent.

3. Diplodal: Dalam beberapa kasus tabung dikenal sebagai prosodus muncul antara kanal incurrent dan ruang flagellated. Ruang flagellated membuka ke kanal excurrent oleh apopyles dan ini bersatu untuk membentuk tabung yang lebih besar, yang terbesar mengarah ke osculum, Sehingga arus aliran air yang masuk pada tipe canal Leuconoid adalah: Ostia Subdermal pores incurrent canals prosopyle flagellated Chambers apopyle excurrent canals larger channels osculum.

\subsubsection{Ciri-ciri Anatomi Spons}

Anatomi spons terdiri atas tiga tipe saluran air, yaitu askonoid, sikonoid, dan leukonoid pencernaan secara intraseluler di dalam koanosit dan amoebosit. Cara hidup secara heterotof.Makananya adalah bakteri dan plankton.Makanan yang masuk kedalam tubuhnya berbentuk cairan.Pencernaan dilakukan secara intraseluler di dalam koanosit dan amoebosit. Reproduksi hewan ini dilakukan secara aseksual maupun seksual. Umumnya, spons bersifat hermafrodi. Reproduksi secara aseksual terjadi dengan pembentukan pucuk/tunas baru dan gemmule. Dilakukan dengan membentuk pucuk/tunas pada tubuh induk lamakelamaan terbentuk koloni porifera. Fragmen-fragmen kecil melepaskan diri dari spons induk, menempel pada substrat, dan tumbuh menjadi spons baru. Reproduksi aseksual porifera air tawar bisa juga dilakukan untuk mengatasi kondisi lingkungan yang kering dengan pembentukan gemule (butir benih / tunas internal), yaitu sel amebosit yang dibungkjus oleh tiga lapisan kuat. Gemmule dihasilkan menjelang musim dingin di dalam tubuh Porifera yang hidup di air tawar. Gemule terlihat pada saat induk hancur. Jika kondisi lingkungan membaik kemabali, maka lapisan pelindung pecah dan kehidupan dilangsungkan kembali.

Reproduksi secara seksual dilakukan dengan pembuahan sel telur suatu porifera oleh sel sprema porifera yang lain secara internal. Masingmasing individu menghasilkan sperma dan ovum. Kedua sel kelamin 
terbentuk dari perkembangan sel-sel amebosit atau koanosit. Sel-sel sperma dilepaskan ke dalam air, kemudian masuk ke tubuh spons lain bersama aliran air melalui ostium untuk melakukan fertilisasi. Hasil pembuahan berupa zigot yang berkembang menjadi larva bersilia. Larva tersebut keluar dari tubuh porifera induk melalui oskulum, kemudian melekat di dasar perairan untuk tumbuh menjadi dewasa.

a. Calcarea (Calcisspongiae)

Calcarea (dalam latin, calcare $=$ kapur) atau Calcispongiae (dalam latin, calci $=$ kapur, spongia $=$ spons $)$ memiliki rangka yang tersusun dari kalsium karbonat.Tubuhnya kebanyakan berwarna pucat dengan bentuk seperti vas bunga, dompet, kendi, atau silinder.Tinggi tubuh kurang dari $10 \mathrm{~cm}$.Struktur tubuh ada yang memiliki saluran air askonoid, sikonoid, atau leukonoid.Calcarea hidup di laut dangkal, contohnya sycon, Clathrina, dan Leucettusa lancifer.

b. Hexactinellida (Hyalospongiae)

Hexactinellida (dalam bahasa yunani, hexa = enam) atau Hyalospongiae (dalam bahasa yunani, hyalo = kaca/transparan, spongia $=$ spons) memiliki spikula yang tersusun dari silika sehingga biasanya juga dikenal dengan bunga karang gelas. Ujung spikula berjumlah enam seperti bintang.Tubuhnya kebanyakan berwarna pucat dengan bentuk vas bunga atau mangkuk.Tinggi tubuhnya ratarata 10-30 cm dengan saluran tipe sikonoid. Hewan ini hidup soliter di laut pada kedalaman $200-1.000$ m.Contoh Hexactinellida adalah Euplectella.

c. Demospongia

Demospongiae (dalam bahasa yunani, demo = tebal, spongia $=$ spons). Demospongie bertulang lunak karena tidak memiliki rangka, jika ada yang memiliki rangka terdiri dari serabut spongin dengan spikula dari silikat atau spongia saja. Tubuh spons jenis ini umumnya berwarna cerah karena mengandung pigmen yang terdapat pada amoebosit, meskipun kadang ditemukan spons yang berwarna gelap, hal ini dapat disebabkan karena spons tersebut telah bermutasi menyesuaikan diri dengan lingkungan tumbuhnya dan nutrisi yang ada serta dinamika spons dalam masa perkembangan biakannya. Fungsi warna diduga untuk melindungi tubuhnya dari sinar matahari. Bentuk tubuhnya tidak beraturan dan bercabang, tinggi dan diameternya ada 
yang mencapai lebih dari 1 meter. Seluruh Demospongiae memiliki saluran air tipe Leukonoid.

Habitat Demospongiae umumnya di laut dalam maupun dangkal, meskipun ada yang di air tawar. Demospongiae adalah satusatunya kelompok spons/porifera yang anggotanya ada yang hidup di air tawar. Demospongiae merupakan kelas terbesar yang mencakup 90\% dari seluruh jenis spons. Contoh Demospongiae adalah spongia sp, hippospongia Niphates digitalis, Euspongia sp, Spongia sp.

Beberapa jenis spons seperti Spongia dan Hippospongia dapat digunakan sebagai spons mandi. Zat kimia yang dikeluarkannya memiliki potensi sebagai obat penyakit kanker dan penyakit lainnya. Porifera juga dapat merugikan karena dapat hidup melekat pada kulit tiram sehingga menurunkan kualitas tiram di peternakan tiram. Secara ekonomis, Porifera tidak mempunyai arti penting. Hewan Demospongia yang hidup di laut dangkal dapat dimanfaatkan oleh manusia, misalnya spons untuk mandi dan pembersih kaca. Sampai di sinilah uraian materi Porifera. Mudah-mudahan tidak ada kesulitan dalam upaya Anda mempelajari materi ini.

Beberapa jenis porifera seperti spongia dan hippospongia dapat digunakan sebagai spons mandi dan alat gosok.Namun, spons mandi yang banyak digunakan umumnya adalah spons buatan, bukan berasal dari kerangka porifera.Zat kimia yang dikeluarkannya memiliki potensi obat penyakit kanker dan penyakit lainnya. Rangka tubuh spons mempunyai nilai ekonomi yang tinggi, karena dapat dimanfaatkan sebagai alat pembersih (penggosok) alami ataupun sebagai pengisi jok (tempat duduk) kendaraan bermotor.

Spons menghasilkan senyawa bioaktif yang berfungsi sebagai pertahanan diri. Senyawa tersebut ternyata berpotensi sebagai bahan obat-obatan. Spesies Petrosia contegnattamengahsilkan senyawa bioaktif yang berkhasiat sebagai obat anti kanker, sedangkan obat antiasma diambil dari Cymbacela. Spons Luffariella variabilis menghasilkan senyawa bastadin, asam okadaik, dan monoalid yang bernilai jual sangat tinggi. 


\section{3. Morfologi Spons}

\section{3. 1. Pengantar Morfologi Spons}

Mikroanatomi adalah mempelajari sel, jaringan, organ, sistem organ, organisasi sel, jaringan, organ, sistem organ, dan organisme suatu makhluk hidup. Khusus spons laut dengan morfologi luar sangat dipengaruhi oleh faktor fisika, kimiawi, dan biologis lingkungannya. Spesimen yang berada di lingkungan yang terbuka dan berombak besar cenderung pendek pertumbuhannya atau juga merambat. Sebaliknya spesimen dari jenis yang sama pada lingkungan yang terlindung atau pada perairan yang lebih dalam dan berarus tenang, pertumbuhannya cenderung tegak dan tinggi. Pada perairan yang lebih dalam spons cenderung memilki tubuh yang simetris dan lebih besar sebagai akibat dari lingkungan yang lebih stabil apabila dibandingkan dengan jenis spons yang sama pada perairan yang dangkal.

Ciri-ciri morfologi spons tubuhnya berpori (ostium), multiseluler, tubuh spons asimetri (tidak beraturan), meskipun ada yang simetri radial, berbentuk seperti tabung, vas bunga, mangkuk, atau tumbuhan, warnanya bervariasi, tidak berpindah tempat (sesil). memiliki tiga tipe saluran air, yaitu askonoid, sikonoid, dan leukonoid pencernaan secara intraseluler di dalam koanosit dan amoebosit. Spons dapat berbentuk sederhana seperti tabung dengan dinding tipis, atau masif bentuknya dan agak tidak teratur. Banyak spons tersusun atas segumpal jaringan yang tak tentu bentuknya, menempel dan membuat kerak pada batu, cangkang, tonggak, atau tumbuh-tumbuhan.

Morfologi luar spons laut dipengaruhi sangat kuat oleh faktor fisika, kimiawi, dan biologis lingkungannya. Spesimen yang berada di lingkungan yang terbuka dan berombak besar cenderung pendek pertumbuhannya atau juga merambat. Sebaliknya spesimen dari jenis yang sama pada lingkungan yang terlindung atau pada perairan yang lebih dalam dan berarus tenang, pertumbuhannya cenderung tegak dan tinggi. Pada perairan yang lebih dalam spons cenderung memilki tubuh yang simetris dan lebih besar sebagai akibat dari lingkungan yang lebih stabil apabila dibandingkan dengan jenis yang sama pada perairan yang dangkal.

Spons dapat berbentuk sederhana seperti tabung dengan dinding tipis, atau masif bentuknya dan agak tidak teratur. Banyak spons juga terdiri atas segumpal jaringan yang tak tentu bentuknya, menempel dan 
membuat kerak pada batu, cangkang, tonggak, atau tumbuh-tumbuhan. Kelompok spons lain mempunyai bentuk lebih teratur dan melekat pada dasar perairan melalui sekumpulan spikula. Bentuk-bentuk yang dimiliki spons dapat beragam. Beberapa jenis bercabang seperti pohon, lainnya berbentuk seperti sarung tinju, seperti cawan atau seperti kubah. Ukuran spons juga beragam, mulai dari jenis berukuran sebesar kepala jarum pentul, sampai ke jenis yang ukuran garis tengahnya $0.9 \mathrm{~m}$ dan tebalnya $30,5 \mathrm{~cm}$. Jenis-jenis spons tertentu nampak berbulu getar karena spikulanya menyembul keluar dari badannya.

Sel-sel amoeboid dapat ditemukan pada mesohyl, dan tersusun dari beberapa jenis sel. Archaeocyt adalah sel berukuran besar dengan nukleus yang besar pula. Sel ini merupakan sel fagositosis dan berperan dalam digesti makanan, serta bersifat totipotent. Sel-sel lainnya adalah collencytes, sclerocytes, dan spongocytes, serta choanocytes, terdapat pada bagian dalam mesohyl, sejajar dengan spongocoel. Sel ini berperan dalam pergerakan air dalam tubuh spons dan untuk menyediakan makanan. Gambar 2. 9, menunjukkan struktur organisasi sel-sel penyusun tubuh spons.

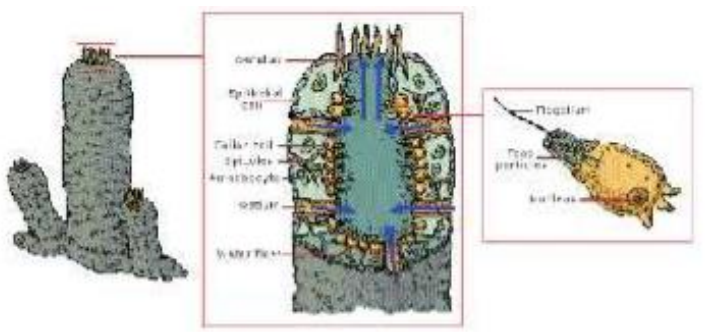

(Sumber: dimodifikasi dari Brusca and Brusca, 1990)

Gambar 2. 9. Struktur morfologi spons

Selain sel-sel yang telah disebutkan di atas, spons juga bersimbiosis dengan beberapa mikroorganisme, seperti bakteri dan fungi. Diperkirakan sekitar $40 \%$ biomassa beberapa spons disusun oleh komunitas bakteri. Bakteri-bakteri tersebut merupakan simbion dalam tubuh spons. Beberapa penelitian menunjukkan bahwa simbion-simbion tersebut memiliki peranan dalam produksi senyawa bioaktif yang berfungsi dalam adaptasi ekologi spons. Oleh karena itu perlu dilakukan analisis lebih jauh untuk mengetahui pengaruh morfologi dan komposisi penyusun biomassa spons, termasuk bakteri simbionnya, terhadap mekanisme produksi senyawa bioaktif spons dan sifat dari biomassa dan 
mikrosimbion berpotensi sebagai biodegradator hidrokarbon dan bioapsorpsi logam berat. Data ini memberikan pengetahuan dasar untuk mempelajari morfologi dan biomassa sel beberapa jenis spons yang diperoleh dari sekitar kawasan Kepulauan Spermonde Sulawesi Selatan. Spons Callyspongia, A. aptos dan Petrosia sp., sebagai langkah awal untuk melihat performa spons dengan segala macam keunikan dan karakter yang dimiliki, termasuk dalam memahami mekanisme dan cara beradaptasi fisologis spons tersebut terhadap lingkungan dan produksi senyawa bioaktifnya termasuk sebagai potensi dan sifat sebagai anti bakteri.

Kelompok spons lain mempunyai bentuk lebih teratur dan melekat pada dasar perairan melalui sekumpulan spikula. Bentuk-bentuk yang dimiliki spons dapat beragam. Beberapa jenis bercabang seperti pohon, lainnya berbentuk seperti sarung tinju, seperti cawan atau seperti kubah. Ukuran spons juga beragam, mulai dari jenis berukuran sebesar kepala jarum pentul, sampai ke jenis yang ukuran garis tengahnya $0.9 \mathrm{~m}$ dan tebalnya $30,5 \mathrm{~cm}$. Jenis-jenis spons tertentu nampak berbulu getar karena spikulanya menyembul keluar dari badannya.

\section{3. 2. Ciri-ciri morfologi Spons}

Spons umumnya memiliki bentuk tubuh sangat bervariasi yaitu ada yang menyerupai kipas, batang, terompet dan lainnya, hewan ini sebagian membentuk koloni yang sering tampak tidak teratur sehingga tampak sebagai tumbuhan. Warnanya bermacam-macam dan dalam tubuhnya mengandung ganggang yang memiliki warna dan mereka mengadakan simbiosis. Spons dapat berbentuk sederhana seperti tabung dengan dinding tipis, atau massif bentuknya dan agak tidak teratur. Banyak sponge juga terdiri atas segumpal jaringan yang tak tentu bentuknya, menempel dan membuat kerak pada batu, cangkang, tonggak, atau tumbuh-tumbuhan. Hasil identifikasi morfologi spons, berdasarkan bentuk pertumbuhan, warna fisik, jenis choanosome kerangka spicule yang dikombinasikan dengan keadaan lingkungan pertumbuhan spons dapat disimpulkan bahwa keempat sampel spon yang diperoleh pada Pulau Kadingareng Keke, merupakan spon kelas Demospongiae ordo, family dan spesies terinci ditunjukkan dalam Tabel 2. 1, berikut: 
Tabel 2. 1. Hasil Identifikasi Morfology Spons

\begin{tabular}{|c|c|c|c|c|}
\hline $\begin{array}{l}\text { Kode } \\
\text { Sampel }\end{array}$ & Spesies Spons & Famili & Ordo & Kelas \\
\hline Sp la & $\begin{array}{l}\text { Petrosia (Strongylophora) } \\
\text { corticata }\end{array}$ & Petrosiidae & Haclosclerida & Demospongiae \\
\hline Sp 2a & Niphates sp. & Niphatidae & Haclosclerida & Demospongiae \\
\hline $\mathrm{Sp} 3 \mathrm{a}$ & Hyrtios erectus & Thorectidae & Dictyoceratida & Demospongiae \\
\hline $\mathrm{Sp} \mathrm{4a}$ & Clathria (Thalysias) reinwardti & Microcionidae & Poeciloslerida & Demospongiae \\
\hline Sp 5a & Callyspongia sp & Callyspongiiadae & Callyspongia & Demospongiae \\
\hline Sp 6a & Aulleta sp. & Axinellidae & Axinellida & Demospongiae \\
\hline Sp 7a & Neopetrosia sp & Petrosiidae & Halichondrida. & Demospongiae \\
\hline Sp 8a & Callyspongia aerizusa & Callyspongiiade & Haplosclerida & Demospongiae \\
\hline Sp lb & Callyspongia sp & Callyspongiidae & & Demospongiae \\
\hline Sp 2b & Coelocarteria singaporensis & Chalinidae & & \\
\hline Sp 3b & $\begin{array}{l}\text { Callyspongia (Cladocalina) } \\
\text { vaginalis }\end{array}$ & $\begin{array}{l}\text { Callyspongia } \\
\text { (Cladocalina) } \\
\text { vaginalis } \\
\end{array}$ & & Demospongiae \\
\hline $\mathrm{Sp} 4 \mathrm{~b}$ & Haliclona (Haliclona & Chalinidae & Haliclona & Demospongiae \\
\hline
\end{tabular}

Morfologi luar spons dipengaruhi oleh faktor fisik, kimiawi, dan biologis serta lingkungan terpat perkembangbiakannya. Spesimen spons yang berada di lingkungan terbuka dan berombak cenderung memiliki pertumbuahn pendek dan dapat merambat, sebaliknya spons jenis spesies sama, jika berada pada lingkungan terlindung atau pada perairan lebih dalam serta berarus tenang, biasanya memiliki pertumbuhan cenderung tegak dan tinggi. Karakteristik histomorfologi ke delapan sampel spons yang berasal dari Pulau Kodingareng Keke khususnya bentuk pertumbuhan, konsistensi, bentuk permukaan, keberadaan choanosome, kerangka tubuh dan tipe spicule, berturut-turut ditunjukkan pada Gambar 2.10-2.17, berikut:

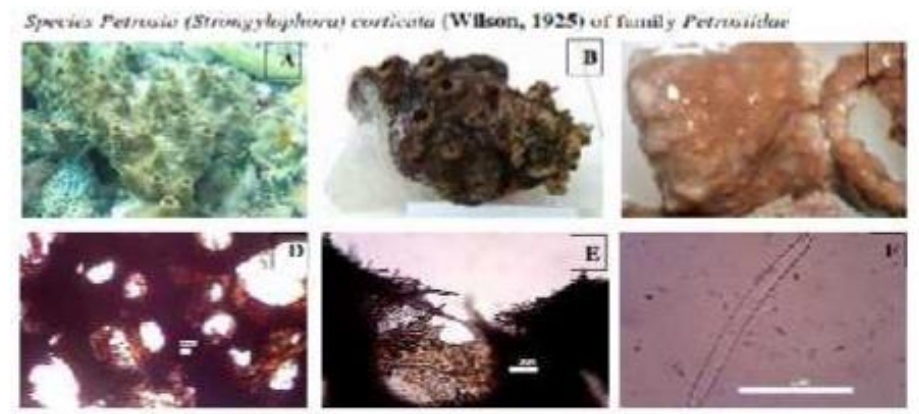

Gambar 2. 10. (a) Pertumbuhan berbentuk kulit dengan cerobong oscular tinggi berwarna coklat muda; (b) Konsistensi membentuk pola batu yang menunjukkan kekuatan spons jenis ini; (c) Permukaan spons yang tidak rata dan berlendir,

Spons Petrosia (Strongylophora) corticata, (Gambar 2. 10), dengan ciri bentuk pertumbuhan berupa kulit berbentuk cerobong dengan 
oscular tinggi, tampak cerah dengan warna coklat muda, berkonsistenis tegas dan kuat, bentuk permukaan tidak rata dan berlendir halus, dengan kerangka berupa spicule multi, kerangka dengan serat sedikit dan padat dan memiliki spicule tipe megasclere. Sedangkan morfologi spons jenis Niphates, ditunjukkan pada Gambar 2. 11, berikut:

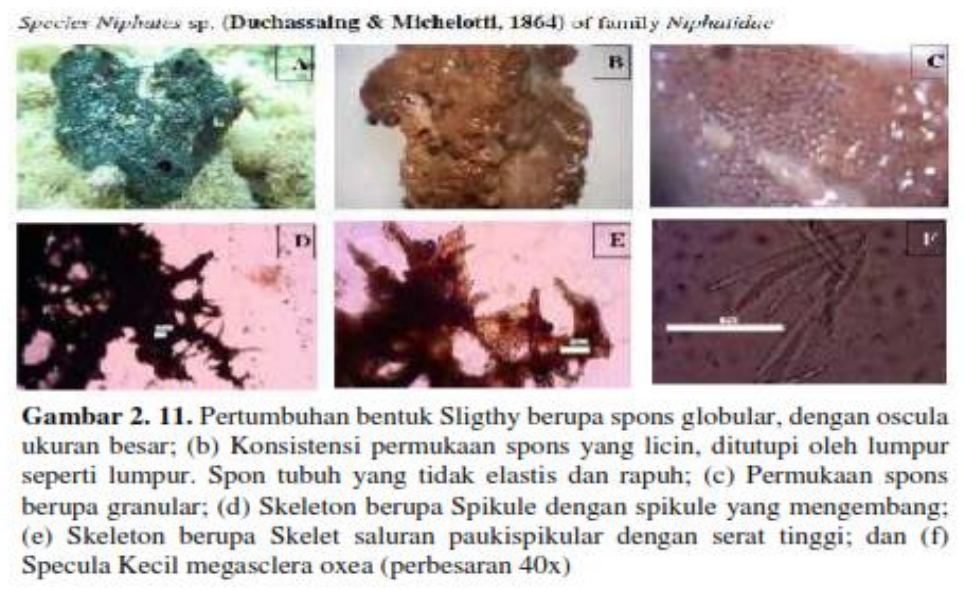

Spons spesies Niphates, sp, (Gambar 2.11) memiliki bentuk pertumbuhan melingkar dengan Oscula ukuran besar, konsistensi permukaan tubuh licin ditutupi lumpur menyerupai lendir. Tubuh spons tersebut tidak elestis dan rapuh dan memiliki kerangka spicule echinating berupa pilar membentuk trapesium berserat dan oxea kecil. Spons di atas merupakan spons ordo sama, yakni Haclosclerida termasuk dalam kelas Demospongiae.

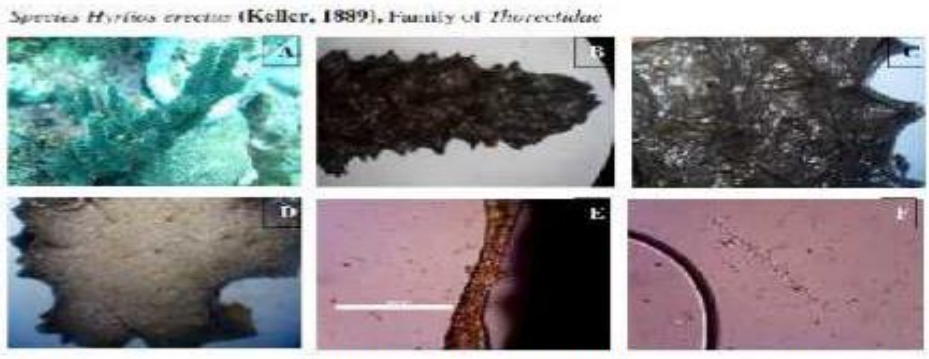

Gambar 2. 12. (A) Pertumbuhan Spons membentuk percabangan, berwarna hitam; (b) Konsistensi berkarakter oscular, lapisan spons yang tidak teridentifikasi; (c) Permukaan membentuk ornamen berbentuk piramida; (d) Choanosom membentuk bagian yang terpotong bagian tubuh, dimana tubuh spons tersebut memiliki serat yang banyak; (e) Skeleton dengan Kerangka bernoda fiber; dan (f) Spicula megaclera (pembesaran 10x), tidak ada microsclera.

Sampel spons berikutnya adalah spesies Hyrtios erectur (Gambar 2. 12), family Thoerectidae, ordo Dictyoceratida, juga merupakan spons 
kelas Demospongiae dengan bentuk pertumbuhan bercabang dua, jika berkumpul terlihat berwarna hitam, namun karakteristik khusus tidak teridentifikasi, sedangkan bentuk permukaan piramida, dengan kerangka menempel berupa serabut, sedangkan spicule berupa substylostyle.

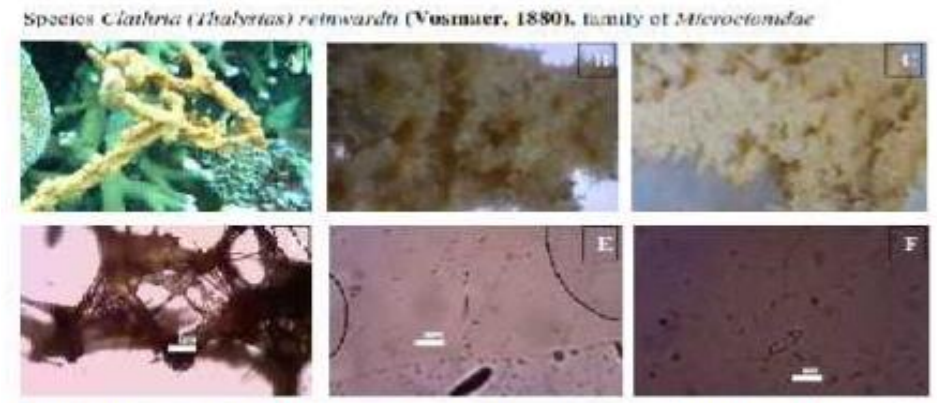

Gambar 2. 13. Permukaan spons kuning yang bercabang-pertahankan; (b) Konsistensi lembut, spons tersebut bisa dipadatkan; (c) Proyeksi tubuh spons rapuh saat mongering; (d) Choanosom: berupa Anastoming kerangka choanosome retikulat; (e) Megasclere gaya panjang; dan (f) Mikroskeler tampak dengan jelas

Gambar 2. 13, merupakan spons spesies Clathria (Thalysias) reinwardti, family Microcionidae dengan ciri-ciri bentuk pertumbuhan bercabang-cabang, konsistensi lembut dan kompresibel, sedangkan badan spons jenis ini rapuh apabila kering dan anatomi choanosome berupa Microsclere Chelae.

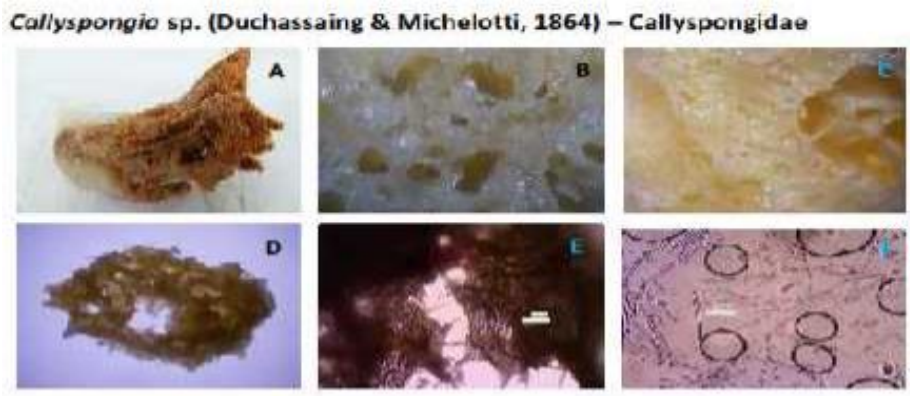

Gambar 2. 14. (a) Pertumbuhan Spons berwarna oranye. Kompresibel di dalam air; (b) Konsistensi yang rapuh dan termasuk rapuh ketika mongering: (c) Bentuk Oscule bulat menyebar ke seluruh tubuh; (d) Choanosome sebagai Penampang tubuh dan memiliki daerah berongga diduga ruang choanocyte; (e) Skeleton dengan Kepadatan tinggi serat dan rangka unispicular; dan (f) Spicula yang berulang dan seragam berukuran besar

Spons spesies Callyspongia sp, (Gambar 2.14), masuk dalam family Callyspongiiadae dengan ciri-ciri pertumbuhan berwarna orange, konsistensi rapuh termasuk jika spons tersebut mongering, Choanosom 
yang tidak berongga. Spons jenis ini masuk dalam ordo Callyspongia kelas Demospongia.

Auletta sp. (Schmidt, 1870) - Axinellidae

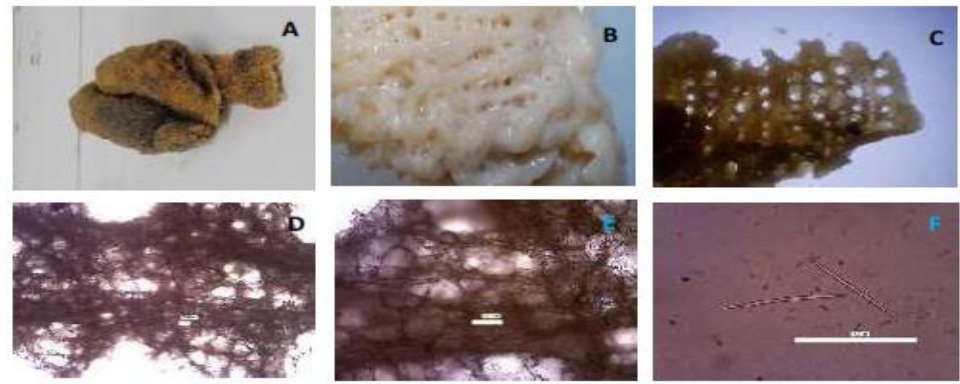

Gambar 2. 15. (a) Pertumbuhan Spons berwarna kuning gelap. Bentuk silinder tipis; (b) Konsistensi spons, kompresibel, rapuh dan tubuh rapuh meskipun dalam keadaan kering; (c) Skeleton membentuk spikular menyerupai panci, (plumoreticulate); (d) Skeleton choanosme membentuk Anostoming; (e) Membentuk serabut fiber saling berhubungan dan (f) Spicula slender oxea megasclere

Spons berikutnya adalah spesies Asulleta sp (Gambar 2.15), termasuk dalam family Axinellida, ordo Axinellida dan masih termasuk dalam kelas Demospongia. Ciri-ciri yang tampak dari spons ini adalah pertumbuhan berwarna kuning gelap dengan bentuk tubuh berupa selinder tipis konsistensi rapuh termasuk jika spons tersebut mongering, berserabut.

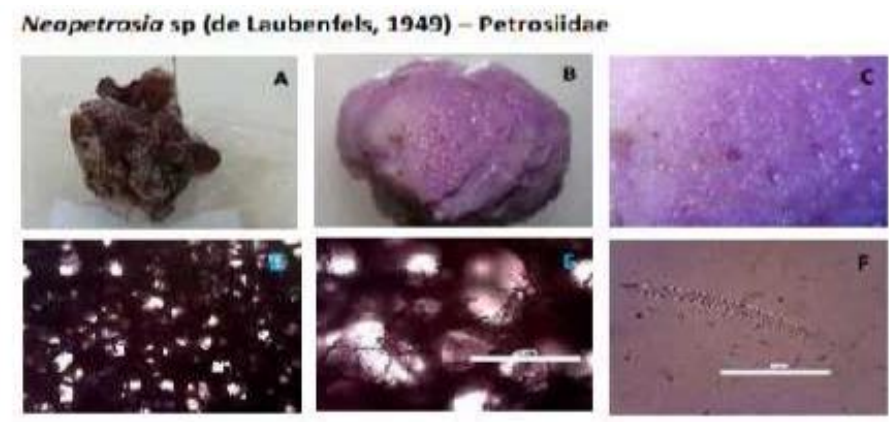

Gambar 2. 16. (a) Pertumbuhan spons berbentuk bola. Berwarna ungu; (b) Bentuk tubuh yang konsistensi keras; (c) Permukaan spons halus; (d) Choanosom berupa skeleton choanosome memadat dan alveolate; (e) Skeleton membentuk kerangka multispikular, tersusun bulat dan(f) Specula yang Oxea megasclere (pembesaran $10 \mathrm{x}$ ), tidak ada Microsclere.

Spons seperti pada Gambar 2. 16 di atas berikutnya adalah spesies Neopetrosia sp, termasuk dalam family Petrosiid, ordo Halichondrida dan masih termasuk dalam kelas Demospongia. Ciri-ciri yang tampak dari 
spons ini adalah pertumbuhan spons berwarna ungu membentuk bola dengan bentuk tubuh konsistensi keras, permukaan yang halus dan skeleton membentuk kerangka multispikuler yang tersusun berbentuk bulat.

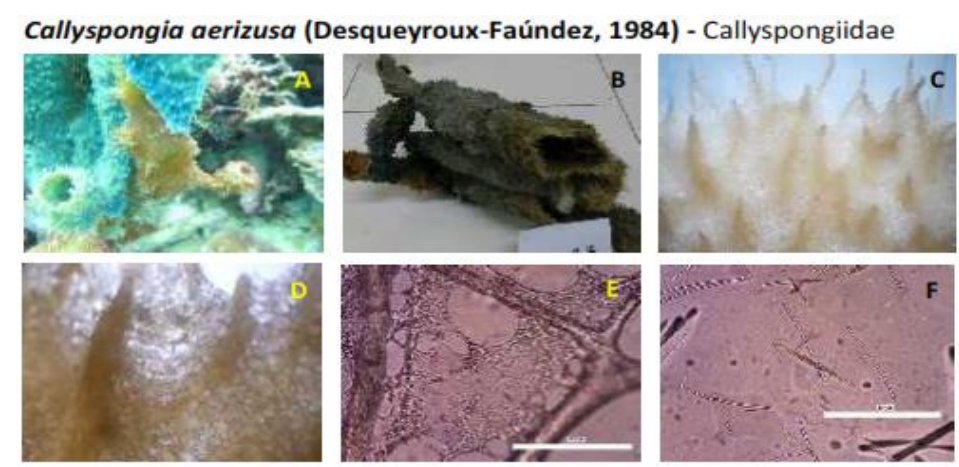

Gambar 2. 17. (a) Pertumbuhan berbentuk Silinder, warna spons biru dan kuning; (b) Warna memudar setelah ditambahkan dengan alcohol; (c) Permukaan spons yang Pappilate; (d) Skeleton berupa serat Primer dan Sekunder, memiliki saluran yang saling berhubungan; (e) Membentuk serta yang kerapatan tinggi; dan (f) Specula berupa Slender oxea (perbesaran 40x), tidak memiliki microsclera.

Spons yang tampak pada Gambar 2. 17, di atas merupakan spons dengan spesies Callyspongia aerizusa. Ditemukan pertama kali dan dilaporkan oleh Desqueyroux-Foundez, 1984. Spons ini termasuk dalam family Callysponginade, ordo Haplosclerida dan masih termasuk dalam kelas Demospongia. Pertumbuhan berbentuk selinder, warna biru kombinasi kuning, memiliki skeleton berserat primer dan memiliki saluran yang saling berhubungan.

Data morfologi beberapa jenis spons yang dianalisis menunjukkan bahwa setidaknya ada 8 jenis spons yang memiliki simbion yang berpotensi mendegradasi komponen hidrokarbon, yakni: 1) Petrosia (Strongylophora) corticata; 2) Niphates sp; 3) Clathria (Thalysias), 4) Callyspongia sp; 5) Neopetrosia sp; 6) Coelocarteria singaporensis; 7) Callyspongia (Cladocalina) vaginalis; dan 8) Haliclona (Haliclona) oculata. Penciri kedua jenis spons tersebut berpotensi mengedradasi hidrokarbon dapat dilihat pada permukaan tubuh yang berlendir atau diselimuti lumpur. Untuk memastikan bahwa spons tersebut di atas mampu mendegradasi hidrokarbon, dapat dilakukan dengan mengekstrak biomassa spons dan mengisolasi mikrosimbion spons tersebut, lalu 
diaktifkan, kemudian diujikan pada area yang tercemar hidrokarbon yang telah diketahui konsentrasinya pada skala laboratorium. Metode yang dilakukan untuk mendegradasi hirokarbon menggunakan biomassa spons atau isolat bakteri dari spons dilakukan dengan kontak antara isolat yang telah diaktifkan dalam sebuah reaktor degradasi yang sederhana. Kinerja mikrosimbion dalam mereduksi hidrokarbon dapat dilihat setelah beberapa hari masa kontak dengan melihat parameter pertumbuhan sel bakteri, kerapatan optik media degradasi, kelimpahan komponen hidrokarbon dan konsentrasi hidrokarbon yang tidak terdegradasi.

Umumnya spons cenderung memiliki morfologi yang berbeda, jika hidup pada dua lingkungan yang berbeda, berakibat sifat, jenis mikroorganisme dan jumlah simbion yang dapat terjadi juga akan berbeda. Faktor, seperti nutrient, arus laut, tingkat cemaran pada laut tempat perkembangbiakan, jenis cemaran, $\mathrm{pH}$, intensitas cahaya, kedalaman dan intensitas ancaman terhadap kehidupan spons diduga sebagai penyebab perbedaan tersebut. Karakteristik utama yang mencirikan suatu jenis spons tersebut mampu mendegradasi hidrokarbon dilihat pada struktur tubuh yang memiliki lendir atau lumpur yang ada dalam tubuh maupun yang menyelimuti tubuh spons. Lendir ini mengandung bakteri yang bertugas memproduksi sejumlah enzim sebagai respon atas ancaman yang dialami oleh spons, sehingga spons yang hidup pada area tercemar hidrokarbon dimana spons terebut tetap dapat bertahan hidup.

\section{4. Histologi Spons}

Histologi adalah ilmu yang mempelajari tentang struktur jaringan secara detail menggunakan mikroskop pada sediaan jaringan yang dipotong tipis, salah satu dari cabang-cabang biologi. Histologi dapat juga disebut sebagai ilmu anatomi mikroskopis. llmu yang mempelajari jaringan tubuh secara mikroskopis.

Contoh pengamatan histologi spons melalui preparat histologi ditunjukkan pada spons jenis Aaptos aaptos dan spons Petrosia sp. Data yang teramati pada spons A. aaptos, yakni memiliki spikula oxea yang tersebar di bagian ektosom (korteks) dan spikula style serta strongyle yang terdapat di bagian ektosom (korteks) dan endosom (medulla). Hasil yang didapatkan dari pengamatan histologi kedua jenis spons, dengan menggunakan mikroskop fase kontras, menunjukkan bahwa komponen 
struktur yang dapat diidentifikasi adalah komponen penyusun skeleton (spikula dan jaringan spongin), serta sel yang berukuran besar yang diperkirakan sebagai archaeocyt. Struktur sel spons Petrosia sp., yang teramati dari preparat histologi menunjukkan jaringan skeleton yang terdiri dari susunan spikula isotropik (seragam) yang padat. Susunan spikula tersebut terdiri dari spikula oxea, style dan strongyle. Archaeocyte tidak terlihat jelas pada preparat histologi yang diamati dengan mikroskop fase kontras. Jaringan spongin terlihat sedikit transparan, mengikat spikula yang padat, terutama pada bagian ektosom (korteks).

Spons A. aaptos menunjukkan persentase komponen penyusun skeleton (spikula dan sel debris) mencapai 55, $9 \%$, sementara sel spons (choanosome) dan pellet bakteri simbion masing-masing mencapai 14,2 $\%$ dan $29,9 \%$. Komposisi fraksi sel ini lebih dipengaruhi oleh morfologi spons. A. aaptos memiliki morfologi yang tidak keras, dengan susunan spikula oxea, yang tidak terlalu padat, tersebar pada bagian ekstosom. Selain itu ditemukan juga spikula style dan strongyle pada bagian ektosom dan endosom. Hasil pengamatan secara histologi menunjukkan bahwa sel archaeocyte ditemukan pada lapisan mesohyl, dalam jumlah yang cukup banyak. Berbeda dengan A. aaptos, Petrosia sp. memiliki fraksi komponen skeleton (spikula dan sel debris) yang lebih besar, yaitu mencapai 68, 6\%. Fraksi sel lainnya hanya mencapai $19,7 \%$ (sel spons/ choanosome) dan $11,7 \%$ (pellet bakteri simbion). Hal ini menyebabkan morfologi spons yang lebih kaku dan mengandung spikula yang tersebar secara padat. Susunan spikula tersebut terdiri dari spikula oxea, style dan strongyle. Spikula ini terutama ditemukan tersebar pada lapisan ektosom. Sementara itu, sel archaeocyte pada lapisan mesohyl tidak terlihat dengan jelas, dan hanya dalam jumlah yang tidak terlalu banyak.

Persentase fraksi pellet bakteri simbion yang rendah dapat mendukung teori bahwa spons ini hanya mengandung bakteri simbion dalam jumlah kecil. Selain itu, pengamatan histologi juga menunjukkan serat spongin yang berlimpah, mendukung terciptanya morfologi yang keras dan padat (kasar). Jika sebagian atau keseluruhan spikula bersilika ditutupi oleh serat spongin ini, maka struktur spons menjadi lebih kaku. Dengan demikian, dapat dikatakan bahwa biomassa spons Petrosia sp. lebih dipengaruhi oleh sel- sel spons dan komponen penyusun skeleton. Spons yang hidup pada daerah yang subur atau kaya bahan organik, akan 
memiliki biomassa sel yang tinggi, namun hanya mengandung sedikit sekali bakteri simbion. Hal ini diduga dikarenakan tersedianya cukup nutrisi untuk pertumbuhan dan kebutuhan hidup spons, sehingga asosiasi dengan mikroba/ bakteri simbion tidak terlalu dibutuhkan dalam mekanisme adaptasi fisiologis spons tersebut.

Hasil pengamatan histologi pada jenis spons yang lain ditunjukkan melalui preparat histologi spons Callyspongia sp, juga memiliki spikula oxea yang tersebar di bagian ektosom (korteks) dan spikula style serta strongyle yang terdapat di bagian ektosom (korteks) dan endosom (medulla). Gambar 2. 18, menunjukkan struktur sel spons Callyspongia sp. Pada gambar tersebut juga dapat diamati sel- sel archaeocyt (amoebocyt) dengan nukleus berukuran besar. Hasil yang didapatkan dari pengamatan histologi jenis spons tersebut, dengan menggunakan mikroskop fase kontras, menunjukkan bahwa komponen struktur yang dapat diidentifikasi adalah komponen penyusun skeleton (spikula dan jaringan spongin), serta sel yang berukuran besar yang diperkirakan sebagai archaeocyt.

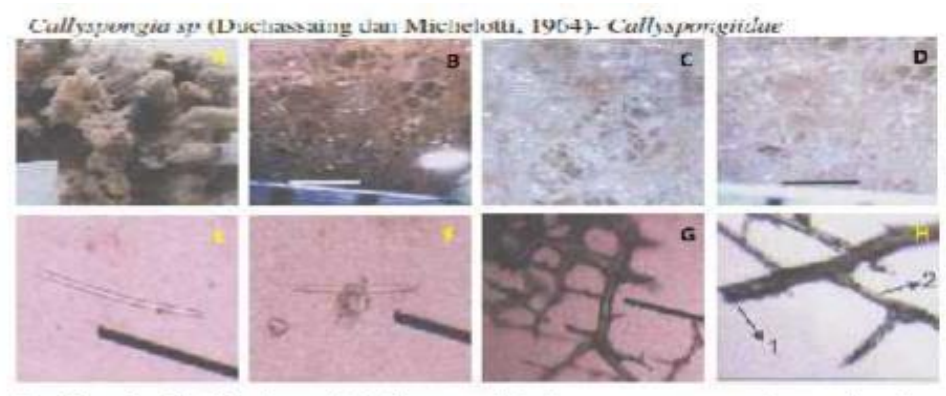

Gambar 2. 18. Hasil analisis histomorfologi spons menggunakan mikroskop haesitometer, yakni: spesies Callyspongia sp.; a) pertumbuhan membentuk massiva; b) hasil pewarnaan dengan EtOH; c) tekstur hasil kompres; d) struktur permukaan setelah diperbesar; e) megascleres axea berupa garis singgung; f) tidak memiliki microscleres, spicula relatif rendah; g) susunan skeleton tidak beraturan dan berisi spongin; h) skeleton terdiri atas dua bagian, yakni skeleton utama (no.1) dan skeleton serabut (no. 2). skeleton berjenis isodictyal yang menyusun beberapa spicula. Jenis spicula : puni-pauci

Spons Petrosia sp berdasarkan pengamatan histologi menunjukkan bahwa Petrosia sp memiliki spikula oxea yang tersebar di bagian ektosom (korteks) dan spikula style serta strongyle yang terdapat di bagian ektosom (korteks) dan endosome, (medulla). Gambar 2. 19, menunjukkan jaringan skeleton yang terdiri dari susunan spikula isotropik (seragam) yang padat. Susunan spikula tersebut terdiri dari spikula oxea, 
style dan strongyle. Archaeocyte tidak terlihat jelas pada preparat histologi yang diamati dengan mikroskop fase kontras. Jaringan spongin terlihat sedikit transparan, mengikat spikula yang padat, terutama pada bagian ektosom (korteks).

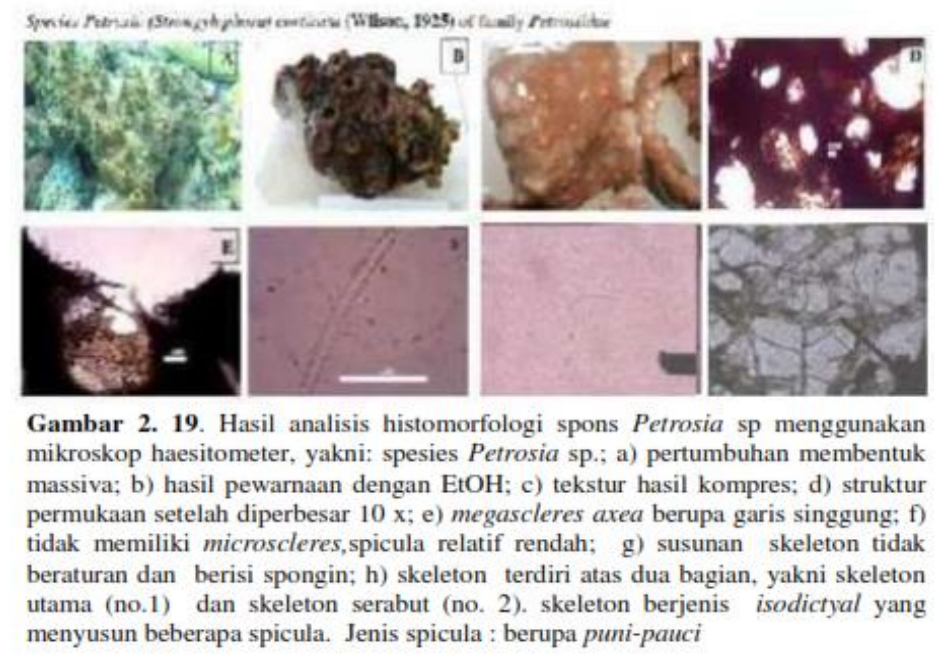

Secara umum, bakteri simbion dapat ditemukan di dalam sel-sel amoebocyte (archaeocyte) dan pada lapisan mesohyl secara ekstraseluler, atau tidak berada di dalam sel spons. Selain itu, bakteri simbion juga dapat ditemukan pada bagian permukaan luar tubuh spons, atau biasa dikenal dengan sebutan bakteri epibiotik/epibion. Mikroba simbion (bakteri dan fungi) dapat berada di dalam tubuh spons karena aktivitas penyaringan makanan (filter feeder) dari lingkungan perairan, kemudian mengalami adaptasi dan mekanisme simbiosis dengan spons inang. Bakteri- bakteri kemungkinan bukan merupakan bakteri yang bersimbiosis secara obligat (host-spesificity), melainkan bersifat komensalisme atau mutualisme. Namun demikian, mekanisme simbiosis simbion dan spons belum banyak diketahui dan masih harus diteliti lebih lanjut. Contoh lain hasil pengamatan histologi terhadap beberapa jenis spons yang diperoleh dari Pulau Kodingareng Keke seperti ditunjukkan pada Gambar 2.20 dan 2.21, berikut: 


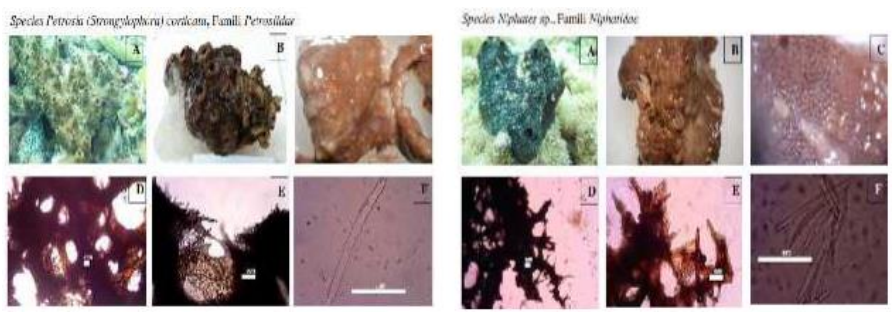

Gambar 2.20 (A) Bentuk pertumbuhan bergerombol. Kulit berbentuk cerobong memiliki oscular tinggi. bercahaya berwarna coklat muda, (B) Konsistensi: tegas, menunjukkan kekuatan, (C) Permukaan spons yang tidak rata dan berlendir, proyeksi halus, (D) Choanosome dengan kerangka spicule multispicular, (E) Kerangka kurang serat dengan spicule padat dan (F) Spicule: tipe Megasclere: berupa Oksida. Gambar 2.21. (A) Bentuk pertumbuhan: Sponge melingkar gligthy, dengan oscula ukuran besar, (B) Konsistensi: permukaan licin, ditutupi oleh lumpur seperti lendir.Tubuh yang tidak elastis dan rapuh, (C) Konsistensi: permukaan licin, ditutupi lumpur seperti lumpur. Spel tubuh yang tidak elastis dan rontok, (D) Kerangknya: berupa spicule dengan spidol echinating, (E) Kerangknya membentuk Pilar trapesium dengan serat tinggi, dan (F) Spicule: megasclera oxea kecil.
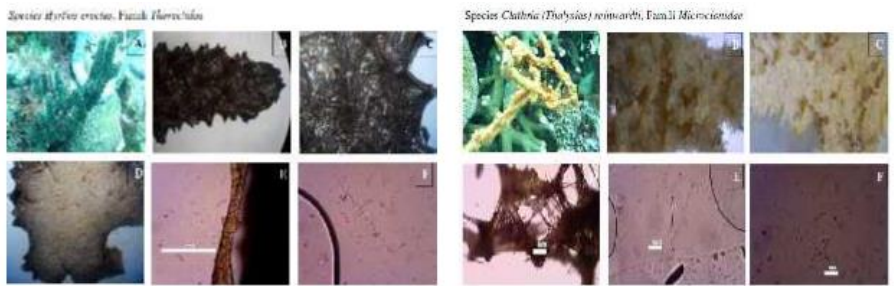

Gambar 2.22. (A) Bentuk Pertumbuhan: spons bercabang Digit. Konsentrat berwarna hitam, (B): Karakteristik yang tidak teridentifikasi, tegas, berdaging, (C) Permukaan berbentuk piramida, (D) Choanosome membentuk bagian potongan tubuh. Berat serat tubuh spong, (E) Kerangka menempel berupa serabut, (F) Spicule: megaplera Substylostyle. Gambar 2.23 (A) Bentuk Pertumbuhan: spons bercabang- cabang, (B) Konsistensi lembut dan kompresibel, (C) Proyeksi: badan spons yang rapuh saat dikeringkan, (D) Choanosome: Anastoming mengulang seperti kerangka choanosome, (E ) Megasclere berbentuk klasik dan (F) Microsclere Chelae microsclere.

Beberapa penelitian berhasil membuktikan bahwa komposisi bakteri simbion dan kelimpahannya sangat dipengaruhi oleh perubahan suhu, iklim, dan tingkat fotosintesis spons. Terkadang pada beberapa jenis spons ditemukan adanya lendir, hal ini terjadi karena kemungkinan habitat spons tersebut mengalami kekeruhan dan sedimentasi sehingga memaksa spons untuk memproduksi lendir dalam rangka melindungi tubuhnya.

Hasil analisis histomorfologi empat jenis spons yang diperoleh dari Pantai Melawai Balikpapan sebagaimana ditunjukkan pada Tabel 2.2, disimpulkan bahwa 4 spesies spons yang teridentifikasi terdistribusi dalam tiga famili. 
Tabel 2.2. Analisis histomorfologi keempat jenis spons asal Pantai Melawai Balikpapan

\begin{tabular}{|c|l|l|l|}
\hline Kode sampel & \multicolumn{1}{|c|}{ Spesies } & \multicolumn{1}{c|}{ Famili } & \multicolumn{1}{c|}{ Penemu } \\
\hline Sp. 1 & Callyspongia sp & Callyspongiidae & $\begin{array}{l}\text { Duchassaing \& } \\
\text { Michelotti, 1964 }\end{array}$ \\
\hline Sp. 2 & $\begin{array}{l}\text { Coelocarteria } \\
\text { singaporensis }\end{array}$ & Chalinidae & Carter, 1883 \\
\hline Sp. 3 & $\begin{array}{l}\text { Callyspongia } \\
\text { (Cladocalina) } \\
\text { vaginalis }\end{array}$ & $\begin{array}{l}\text { Callyspongia } \\
\text { (Cladocalina) } \\
\text { vaginalis }\end{array}$ & Lamarck, 1814 \\
\hline Sp. 4 & $\begin{array}{l}\text { Haliclona } \\
\text { (Haliclona) oculata }\end{array}$ & Chalinidae & Pallas, 1766 \\
\hline
\end{tabular}

Tabel 2.2 menunjukkan bahwa, kode sampel Sp.1 adalah spesies Callyspongia $s p$ merupakan famili Callyspongiidae, kode sampel Sp.2 merupakan spesies Coelocarteria singaporensis dan kode Sp.4 adalah spesies Haliclona (Haliclona) oculata merupakan famili Chalinidae, sedangkan kode Sp.3 adalah spesies Callyspongia (Cladocalina) vaginalis famili Callyspongia (Cladocalina) vaginalis

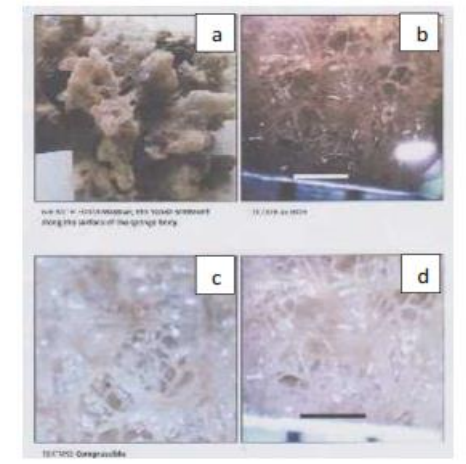

a) pertumbuhan membentuk massiva, oscula berserak sepanjang permukaan badan spons:

b) hasil pewarnaan dengan EtOH

c) tekstur hasil kompres;

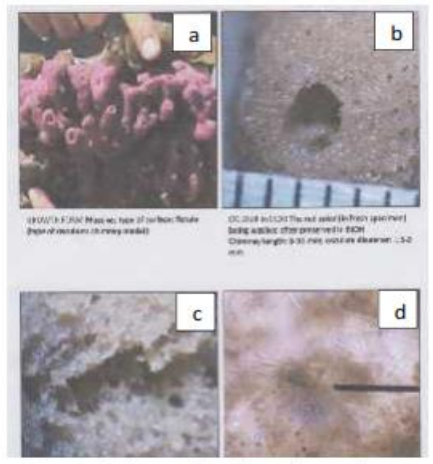

a) pertumbuhan membentuk massiva, oscula berserak sepanjang permukaan badan spons; b) hasil pewarnaan dengan $\mathrm{EtOH}$;

c) tekstur hasil kompres:

d) struktur permukaan setelah diperbesar

Gambar 2.23. Histomorfologi spons spesies a) Callyspongia $s p$ (Gambar kiri) dan b) Coelocarteria singaporensis (Gambar kanan)

Spesies spons tersebut di atas merupakan jenis yang umum ditemukan pada kondisi lingkungan perairan laut termasuk Pantai Melawai Balikpapan, kecuali spons kode Sp2 (Coelocarteria singaporensis), adalah jenis yang jarang ditemukan. Temuan adanya spons pada Pantai Melawai Balikpapan yang tercemar hidrokarbon disebabkan karena spons tersebut telah menyesuaikan diri dengan lingkungan ekstrim karena susunan DNA spons telah bermutasi untuk menyesuaikan dengan habitatnya agar dapat bertahan hidup. 
Proses penentuan spesies spons didasarkan pada data analisis histomorfologi tentang pertumbuhan spons. Sampel kode SP.1, terlihat pertumbuhan yang membentuk massiva dan oscula berserak sepanjang permukaan badan spons. Struktur sel spons tampak jelas setelah dilakukan pewarnaan dalam EtOH dan diperbesar.

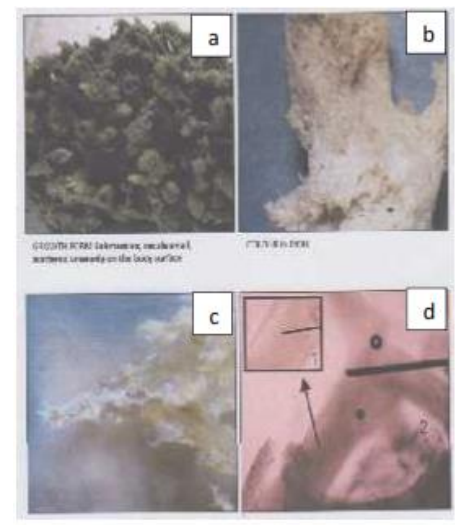

a) pertumbuhan membentuk massiva, oscula berserak sepanjang permukaan badan spons:

b) hasil pewarnaan dengan $\mathrm{EtOH}$;

I d) struktur permukaan setelah diperbesar

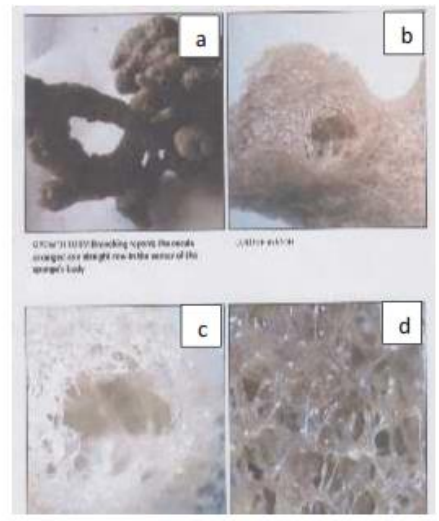

a) pertumbuhan membentuk massiva, oscula
berserak sepanjang permukaan badan spons;
b) hasil pewarnaan dengan EtoH;
c) tekstur hasil kompres;
d) struktur permukaan setelah diperbesar

Gambar 2.24. Histomorfologi spons spesies a) Callyspongia (Cladocalina) vaginalis (Gambar kiri) dan b) Haliclona (Haliclona) oculata (Gambar kanan)

Gambar 2.23 adalah hasil analisis histomorfologi spons asal Pantai Melawai Balikpapan untuk kode sampel Sp.1, Struktur spons yang teramati pada preparat histologi, tampak megascleres axea berupa garis singgung dengan berbagai ukuran, tidak memiliki microscleres dan spicula relatif rendah, skeleton tidak beraturan dan berisi spongin terdiri atas bagian utama dan bagian berserabut. Berdasarkan Gambar 2.24, disimpulkan bahwa spons teridentifikasi dengan spesies Callyspongia sp, family Callyspongiidae, kelas Demospongiae. Hasil ini senada dengan temuan sebelumnya menyatakan bahwa struktur spons sekurangkurangnya memiliki skeleton berisi spikula dan debris atau spongin, sel spons dan kemungkinan terdapat beberapa mikrosimbion (bakteri) yang membentuk sistem hidup komensalisme. 


\section{Bab -3-}

\section{MIKROSIMBION SPONS}

\section{1. Spons dan Mikrooganisme}

Interaksi antara organisme yang hidup dilingkungan akuatik sangat beragam dan peran penting pada interaksi tersebut dijalankan oleh mikroorganisme. Mikroorganisme banyak yang ditemukan tumbuh secara komensal di permukaan juga di dalam berbagai binatang akuatik, beberapa diantaranya terdapat di organ pencernaannya dimana sejumlah bakteri sering terdapat. Mikroorganisme dimakan dan digunakan sebagai makanan oleh sejumlah hewan yang hidup baik itu di sedimen maupun di perairan sehingga faktor nutrisi. Beberapa hewan dapat hidup dengan sejumlah tetentu bakteri maupun fungi.

Mikroba simbion spons (bakteri dan fungi) juga dapat berada di dalam tubuh spons karena adanya transmisi vertikal, atau secara genetis, dari induk ke larva spons. Simbion yang diturunkan secara vertikal, biasanya memiliki sifat simbiosis yang cenderung obligat, dan keberadaannya tidak dipengaruhi oleh faktor lingkungan. Hal ini berhasil dibuktikan oleh beberapa penelitian yang menyimpulkan bahwa simbion spons-bakteri memiliki sifat host-spesificity pada spons inang, dan ditemukan pada semua spesies spons inang yang berasal dari lokasi yang letaknya sangat berjauhan satu terhadap yang lain.

Hubungan simbiotik antara spons dan sejumlah bakteri dan alga, dimana spons menyediakan dukungan dan perlindungan bagi simbionnya dan simbion menyediakan makanan bagi spons. Alga yang bersiombiosis dengan spons menyediakan nutrien yang berasal dari produk fotosintesis sebagai tambahan bagi aktifitas normal filter feeder yang dilakukan spons.

Interaksi antara organisme hidup dilingkungan akuatik sangat beragam dan peran penting pada interaksi tersebut dijalankan oleh mikroorganisme. Mikroorganisme banyak yang ditemukan tumbuh secara komensal pada permukaan dan juga ditemukan pada berbagai binatang akuatik, beberapa diantaranya terdapat pada organ pencernaannya, dimana sejumlah bakteri sering terdapat. Mikroorganisme dimakan dan digunakan sebagai makanan oleh sejumlah hewan yang hidup baik itu di sedimen maupun di perairan sehingga faktor nutrisi. Beberapa hewan dapat hidup 
dengan sejumlah tetentu bakteri maupun fungi. Beberapa jenis bakteri yang ditemukan bersimbion dengan spons Microcionia misalnya Psedomonas, Aeromonas, Vibrio, Achromobacter, Flavobacterium dan Corynebacterium dan Micrococcus. Lubang yang porus pada spons mengandung sejumlah koloni.

Tabel 3. 1. Identifikasi bakteri yang berasal dari Beberapa spons yang Diperoleh dari Pulau Kodingareng Keke, Gugusan Kepulauan Spermonde, (Marzuki, 2016; Suryati et al., 2000)

\begin{tabular}{|c|c|c|}
\hline No & Spesies Spons & $\begin{array}{l}\text { Spesies Bakteri Simbions } \\
\end{array}$ \\
\hline 1 & Acanthela clethera & Flavobacterium, Aeromonas sp \\
\hline 2 & Aplisina $\mathrm{sp}$ & Aeromonas sp \\
\hline 3 & Aulleta sp & Pseudomonas sp. Hil \\
\hline 4 & Callyspongia sp & $\begin{array}{l}\text { Pseudomonas sp, Bacillus Subtilis, Bacillus Flexus, } \\
\text { Pseudomonas stutzeri RCH2 }\end{array}$ \\
\hline 5 & Callyspongia aerizusa & $\begin{array}{l}\text { Pseudomonas stutzeri RCH2, Acinetobacter } \\
\text { calcoaceticus strain } \mathrm{PHCDB} 14\end{array}$ \\
\hline 6 & $\begin{array}{l}\text { Callyspongia (Cladocalina) } \\
\text { vaginalis }\end{array}$ & Pseudomonas sp, Pseudomonas stutzeri RCH2 \\
\hline 7 & Clathria bacilana & Aeromonas sp, Pseudomonas stutzeri RCH2 \\
\hline 8 & Clathria reinwardhi & Aeromonas sp, Pseudomonas stutzeri $\mathrm{RCH} 2$ \\
\hline 9 & Coelocarteria singaporensis & Aeromonas sp \\
\hline 10 & Haliclona (Haliclona) oculata & Flavobacterium \\
\hline 11 & Hyrtios erectus & $\begin{array}{l}\text { Pseudomonas stutzeri RCH2, Pseudomonas stutzeri } \\
\text { strain SLG510A3-8 }\end{array}$ \\
\hline 12 & Jaspis & $\begin{array}{l}\text { Flavobacterium, Bacillus licheniformis strain ATCC } \\
9789\end{array}$ \\
\hline 13 & Neopetrosia $\mathrm{sp}$ & Bacillus licheniformis strain ATCC 9789 \\
\hline 14 & Niphates sp & $\begin{array}{l}\text { Bacillus cohnii strain DSM 6307, Bacillus pumilus } \\
\text { strain GLB197 }\end{array}$ \\
\hline 15 & Phakelia aruensis & Bacillus sp, Aeromonas sp \\
\hline 16 & $\begin{array}{l}\text { Petrosia (Strongylophora) } \\
\text { corticata }\end{array}$ & Bacillus cohnii strain DSM 6307, Bacillus sp \\
\hline 17 & Phyllospongia sp & Vibrio sp, Pseudomonas sp, Aeromonas sp \\
\hline 18 & Reniochalina sp & Acinetobacter $\mathrm{sp}$ \\
\hline 19 & Stylotella aurantiorum & Aeromonas sp, Vibrio sp \\
\hline 20 & Thionella cilindrica & Aeromonas sp \\
\hline 21 & Xetospongia $\mathrm{sp}$ & Enterobacteriabceae, Aeromonas sp \\
\hline
\end{tabular}

Sumber: Data Primer

Hasil penelusuran terhadap spons yang hidup di sekitar Kepulauan Spermonde dimana bakteri yang bersimbion, antara lain: Callyspongia aerizusa, Aulleta sp, Clathria bacilana, Clathria reinwardhi, Hyrtios erectus, Niphates sp, Petrosia (Strongylophora) corticata, Thionella cilindrica dan lainnya, dimana dari berbagai jenis bakteri yang telah diisolasi (Tabel 3. 1), menunjukkan bahwa terhadap sejumlah spesies spons yang hidup di perairan Spermonde, Sulawesi Selatan, bersimbion dengan beberapa jenis kapang dan bakteri yang cukup bervariasi. Satu jenis spons dapat bersimbion dengan hanya 1 bakteri atau mungkin dapat bersimbion dengan 2 sampai 6 bakteri, demikian pula jika satu jenis spons dengan 2 sampel berdasarkan dengan lokasi sampling ada kemungkinan ditemukan jenis bakteri simbion yang berbeda demikian pula jumlah 
simbion bisa berbada, hal ini menunjukkan bahwa lokasi/ habitat spons, nutrisi, pencahayaan, salinitas, kekeruhan termasuk arus laut dan gelombang adalah faktor yang dapat mempengaruhi karakter mikrosimbion spons.

\section{2. Faktor yang Mempengaruhi Terjadinya Mikrosimbion Spons}

\section{2. 1. Ketersediaan Nutrien}

Ketersediaan nutrien berupa senyawa-senyawa organik menjadi faktor yang berkontribusi besar terhadap pertumbuhan dan perkembangan spons. Nutrien yang cukup memberi manfaat terhadap spons dalam mencukupi kebutuhan tubuhnya untuk kelangsungan hidip spon yang lebih baik, meskipun diketahui bahwa banyak jenis spons yang hanya mampu tumbuh 2-3 cm dalam setahun. Ketersediaan nutrisi yang cukup, namun tidak didukung dengan keterpenuhan kondis yang berpengaruh seperti lingkungan perairan yang keruh dan terjadinya pergerakan material nutrian akibat arus dapat menyebabkan pertumbuhan dan perkembangan spons terhambat.

Makanan spons berupa mikroorganisme atau sisa organisme yang telah mati yang berada di kolom air. Organisme mati yang diserap oleh spons berfungsi ganda yakni selain dijadikan makanan, mikroorganisme juga dijadikan simbion dari spons karena mikroorganisme memakai tubuh spons yang berpori-pori sebagai inangnya untuk tempat hidup dan perlindungan. Spons diperkirakan sangat bergantung pada mekanisme pertahanan kimia untuk melawan hewan-hewan predator dan perlekatan dari mikroorganisme phatogenik. Pola makanan spons yang khas yaitu filter feeder (menghisap dan menyaring) makanan, dapat memanfaatkan jasad renik disekitarnya sebagai sumber nutrien diantaranya bakteri, kapang dan xooxanthela yang hidup pada perairan tersebut. Sedangkan kapang, bakteri dan xoxanthelae hidup dan berkembang biak dengan memanfaatkan nutrien yang terdapat pada spons tersebut.

Hambatan lainnya bagi spons dalam pertumbuhannya adalah pencahayaan, ancaman dari perubahan kondisi lingkungan yang ekstrim. Namun demikian bahwa cara hidup spons dengan kemampuan penyerap/mengisap, menyaring dan menyemprotkan cairan memberi efek positif bagi dirinya untuk tetap dapat beradaptasi pada lingkungan yang ekstrim tersebut. 
Ancaman pencemaran (kekeruhan, hidrokarbon, logam berat) dan predator dapat diatasi oleh spons dengan menjadikan dirinya sebagai inang bagi berbagai mikroorganisme yang sewaktu-waktu dapat menghasilkan zat tertentu sebagai respon atas ancaman yang dialami oleh spons tersebut. Warna spons yang indah dan cerah juga diduga kuat oleh nutrisi yang terjadi cukup kompleks, sehingga spons dapat memproduksi zat berupa pytment.

\section{2. 2. Salinitas, temperatur dan $\mathrm{pH}$}

Salinitas yang sesuai dengan suatu jenis spons akan menyebabkan spon tersebut dapat bertahan pada lingkungan hidupnya, namun demikian bahwa beberapa jenis spons yang tidak dapat bertahan dengan tingkat salinitas dimana spons tersebut berdian. Jika terjadi hal demikian, maka spons harus dapat beradaptasi dengan keadaan tersebut atau spons dapat saja melakukan migrasi, namun itu sangat sulit, karena spons merupakan jenis hewan dengan pergerakan paling kecil. Derajat $\mathrm{pH}$ pada area perairan dan temperatur dimana komunitas spons berada berpengaruh buruk dengan pertumbuhan spons, meskipun hal tersebut baru berupa dugaan yang perlu dilakukan analisis lebih lanjut.

\section{2. 3. Topografi}

Dasar laut yang landai memberi manfaat bagi spons untuk menjalan kemampuannya spons sebagai hewan filter feeder dapat berjalan maksimal. Tofografi landai dan dasar laut yang sedikit berlumpur akan menjadikan spons dapat melakukan nutrisi secara maksimal dan efektif. Tofografi dasar laut yang curam menyulitkan spons untuk menjalankan kemampuannnya sebagai hewan filter feeder. Topografi yang landau memungkin terjadinya longsoran-longsoran kecil yang berakibat pada terjadinya kekeruhan. Efek kekeruhan pada habitat spons berdampak pada berkurangnnya suplai oksigen yang masuk ke dalam laut, dimana diketahui bahwa dengan sistem pernapasan spons yang tidak dapat bertahan pada keadaan kekurangan oksigen, dapat menyebabkan spons mengalami gangguan pertumbuhan dan perkembangan ataupun dapat mengalami kematian karena kekurangan oksigen. Karena itulah lingkungan alami spons harus benar-benar kondusif untuk mendukung perkembangannya. 


\section{2. 4. Ancaman Pencemaran}

Sumber pencemaran pada laut cukup banyak dan potensinya untuk terjadi pencemaran cukup tinggi. Sumber pencemaran tersebut seperti tumpahan minyak bumi, kecelakaan transfortasi kapal tanker, transfortasi kapal, dinamikan peningkapan ikan yang terkadang ekstrim, adanya reklamasi di area sekitar komunitas spons, pencemaran oleh sampah plastik, kaleng dan berbagai jenis sampah anorganik. Jenis pencemaran dapat berupa senyawa organik (hidrokarbon), sampah organik (plastik dan sejenisnya), dan senyawa anorganik (logam berat), sampak anorganik (kaleng, potongan logam, dan lain-lain), pencemaran karena bahan kimia tertentu dan bahkan kekeruhan akibat reklamasi dan lain sebagainya. Pencemaean yang terjadi disekitar lingkungan komunitas spons yang menyebabkan air mengalami kekeruhan dan mungkin berbau. Jika keadaan ini berlangsung dalam waktu lama dapat menyebabkan terjadinya suplai oksigen dalam air menurun yang berdampak pada gangguan terhadap spons yang dapat berakibat pada matinya spons tersebut.

Semua bentuk pencemaran tersebut yang terjadi baik disengaja maupun tidak disengaja, berpotensi menimbulkan berdampak negatif pada pertumbuhan spons. Namun terdapat pencemaran tertentu yang justru memicu terjadinya pertumbuahn spons pada suatu area perairan laut. Pencemaran dimaksud adalah keadaan dimana pencemaran yang terjadi meyebabkan terumbu karang mengalami kerusakan. Secara umum terumbu karang yang rusak mengakibatkan timbulnya zat posfat yang merupakan zat yang dapat memicu timbulknya/ tumbuhnya spons jenis tertentu.

\section{2. 5. Arus Laut, Kedalaman dan Gelombang}

Arus laut yang lebih tenang membuat spons lebih nyaman untuk melakukan aktivitas terbatas. Ada dua arus laut yang berpengaruh pada pertumbuhan dan perkembangan spons, yakni arus atas oleh ombak, meskipun pengaruhnya lebih kecil terhadap kehidupan spons, sedangkan arus bawah laut yang terjadi di dasar laut membuat spons dapat terombangan ambing oleh gerakan aur tersebut, dampak lainnya adalah spons sulit untuk melakukan penyerapan dan penyaringan cairan yang mengandung nutrient, dan juga gerakan arus bawah laut berdampak pada 
kemungkinan terjadi kekeruhan yang justru akan menyulitkan bagi spon untuk melakukan aktivitas secara normal.

Berbagai faktor yang berpengaruh pada proses pertumbuhan dan perkembangan spons saling terkait satu terhadap yang lain, artinya faktorfaktor tersebut tidak berdiri sendiri. Pertumbuhan dan perkembagan yang baik bagi spons adalah kondisi lingkungan yang lebih alamiah dan cenderung konstan serta perairan tersebut tidak dalam keadaan tercemar.

\section{3. Hubungan Mikrosimbions Terhadap Jenis Spons}

\section{3. 1. Interaksi Spons terhadap mikroorganisme}

Beberapa jenis mikroorganisme yang dapat bersimbion dengan spons, namun diketahui bahwa tidak ada pola yang baku suatu simbiosis yang dapat terjadi antara spons dengan mikroorganisme. Satu jenis spons dapat bersimbion dengan banyak jenis mikroorganisme, termasuk banyak jenis bakteri, dan sebaliknya jenis mikroorganisme (bakteri) dapat bersimbion dengan lebih dari satu jenis spons. Jenis simbion yang terjadi dipengaruhi oleh beberapa faktor, seperti ketersediaan nutrisi bagi spons, ancaman yang dapat terjadi pada habitat spons, besar kecilnya arus yang dapat membuat mikroorganisme terombang ambing, jenis predator baik oleh spons maupun terhadap bakteri dan juga ada tidaknya pencemaran pada lingkungan hidup spons.

Organisme inang mensintesis senyawa bioaktif sebagai metabolit sekunder untuk melindungi dirinya dan menjaga keseimbangan lingkungan. Spons laut memiliki sumber makanan yang kaya mikroorganisme baru dengan potensi aktivitas farmakologi. Interaksi antara spons dan bakteri terjadi dalam bentuk simbiosis komensalisme dimana dalam interaksi ini dihasilkan senyawa bioaktif. Penapisan bakteri dilakukan dengan menginokulasi suspensi bakteri berasosiasi dengan spons dan karang lunak pada media NA yang telah ditumbuhi bakteri uji. Metode tersebut bersifat kualitatif dan hanya mampu mengetahui bakteri tersebut menghambat bakteri E.coli dan S.aureus tanpa mengetahui efektifitas bakteri tersebut. Diperkirakan mencapai 40\% biomassa beberapa jenis spons disusun oleh komunitas bakteri. Simbiosis cyanobacteria dapat membentuk sepertiga dari total massa dari jaringan hidup di beberapa spons, dan beberapa spons mendapatkan $48 \%$ sampai $80 \%$ dari pasokan energi mereka dari mikroorganisme. 
Spons karnivora dapat berada di dekat ventilasi hidrotermal host metana pemakan bakteri, dan mencerna beberapa dari mereka. Spons dikenal dapat berkolaborasi dengan berbagai organisme lain. Spons dapat berasosiasi dengan sejumlah besar mikroorganisme berbeda meliputi Cyanobacteria, bakteri heterotrofik, alga uniseluler dan mikroorganisme lainnya. Mikroorganisme yang diketahui bersimbiosis dengan spons diantaranya dari kelompok Carkarea, bakteri heterotrofik, sianobakteria, alga hijau, alga merah, kriptofita, dinoflagellata dan diatom. Simbion dapat bersifat spesifik maupun non spesifik terhadap spons sebagai inangnya. Ditemukan beberapa spons yang bersimbiosis dengan mikroorganisme yang spesifik pada spesies spons tunggal. Hal ini terlihat pada simbion antara bakteri spesies proteobacteria dan spons Theonella swinhoei yang menunjukkan asosiasi spesifik.

Salah satu upaya untuk mencegah terjadinya kepunahan spons penghasil zat bioaktif adalah dengan cara mencari mikroorganisrne yang berasosiasi dengan spons sebagai penghasil inhibitor protease, yaitu bakteri. Sekitar $60 \%$ biornassa spons merupakan bakteri dan sianobakteri. Beberapa jenis bakteri yang bersimbiosis dengan spons diperkirakan dapat menghasilkan senyawa-senyawa bioaktif yang dapat digunakan sebagai bahan anti bakteri.

Satu jenis dapat bersimbion dengan 3-6 jenis bakteri, sementara spons yang sama pada area perairan yang berbeda mungkin simbion yang terhadi hanya untuk satu atau dua jensi bakteri. Pola simbion spons dan mikroorganisme yang tidak baku menyebabkan potensi produksi zat aktif oleh spons juga akan bervariasi. Zat aktif spons yang diproduksi sesunggunya bukanlah dihasilkan oleh spons tetapi justru diproduksi oleh bakteri simbion sebagai bentuk respon tubuh bakteri terhadap ancaman predator terhadap inangnya (spons), dimana zat aktif tersebut sepertinya adalah zat yang menyerupai karakter atau berkarakter seperti enzim. Pola simbion spons terhadap bakteri tidak dapat diprediksi, karena begitu rumitnya mirip dengan karakter protein yang saling berkombinasi satu dengan lainnya atau kombinasi protein dengan senyawa lainnya.

\section{3. 2. Isolasi Mikrosimbion Spons}

Terdapat bebebrapa metode yang dapat dilakukan untuk mengisolasi mikrosimbion dari suatu bahan tertentu, seperti mangrove, 
spons, lumpur laut dan lain sebagainya. Ada lima metode yang biasa dilakukan dalam mengisolasi bakteri, yakni: 1) Isolasi pada agar cawan; 2) Metode cawan gores; 3) Metode cawan Tuang; 4) Isolasi pada Medium Cair; dan 5) Isolasi sel tunggal. Teknik isolasi yang ditampilkan dalam buku ini adalah metode isolasi agar tuang. Prosesdur isolasi mikrosimbion spons metode agar Tuang secara sederhanan dengan urutan sebagai berikut:

1. Pilih spons laut jenis tertentu. Spons terpilih disemprot pada bagian permukaan dengan air laut steril dengan perbandingan ukuran spons 1 $\mathrm{cm}^{2}: 5 \mathrm{~mL}$ air laut steril, sehingga hanya bakteri dengan daya gabung yang kuat saja yang akan tersampling.

2. Bagian mesohyl diambil dengan ukuran $\pm 1 \times 1 \mathrm{~cm}$, digerus dan diencerkan dengan Phospat Buffer Saline (PBS) steril dengan perbandingan 1:1.

3. Isolasi bakteri dari permukaan luar menggunakan swab steril, yang diusapkan dengan satu arah pada permukaan luar spons.

4. Swab steril yang telah diusapkan pada permukaan sampel dimasukkan ke dalam tabung pengenceran yang berisi PBS steril dan divorteks.

5. Hasil pengenceran disebar ke dalam cawan petri yang telah berisi media Sea Water Complit (SWC), diinkubasi pada suhu $26^{\circ}$ C selama 2436 jam, diamati pertumbuhan koloni bakterinya.

6. Setiap koloni bakteri yang tumbuh diamati morfologisnya, yakni warna, ukuran dan bentuk koloni. Koloni yang terpilih, diambil menggunakan jarum ose bulat,

7. Isolat dimurnikan menggunakan media yang sama, diperoleh isolat tunggal.

\section{3. 3. Metode Pemisahan biomassa spons laut}

Pemisahan biomassa spons laut dengan bakteri simbionnya dilakukan dengan cara:

1. Disiapkan $5 \mathrm{~g}$ sampel spons laut dalam formalin $2,5 \%$, diencerkan dengan air laut steril yang telah disaring dengan filter $0,2 \mu \mathrm{m}$.

2. Sampel spons dihancurkan dengan blender, Lalu suspensi sel biomassa disentrifugasi untuk memisahkan biomassa sel spons dengan 
bakteri simbion, serta fraksi bakteri dengan dua kali proses sentrifugasi, yakni:

2.1. Sentrifugasi: (1) pada $1.000 \mathrm{rpm}$ selama 5 menit, untuk mendapatkan supernatannya dan

2. 2. Supernatan disentrifugasi lagi pada $4000 \mathrm{rpm}$ selama 10 menit untuk mendapatkan pellet bakteri, setelah itu hasil sentrifugasi masing-masing ditimbang untuk mendapatkan bobot (\%) setiap fraksi sel.

\section{3. 4. Pemurnian isolat bakteri simbion spons laut}

Pada metode direct plating yang dilakukan saat di lapangan, diamati koloni-koloni yang tumbuh sesudah inkubasi selama satu hingga dua minggu. Banyaknya koloni dihitung, kemudian kolonikoloni yang bentuk dan warnanya berbeda diisolasi. Masing-masing koloni dilakukan purifikasi, yaitu dengan cara menggoreskan 1 ose koloni arah zig-zag pada cawan petri yang berisi media $100 \%$ marine-agar kemudian diinkubasi pada suhu $30{ }^{\circ} \mathrm{C}$ selama 1-2 hari. Sesudah tumbuh koloni-koloni baru dilakukan penggoresan ulang pada media $100 \%$ marine agar hingga didapatkan koloni tunggal. Metode pengkayaan dilakukan dengan penyebaran cairan kultur ke media $100 \%$ marine agar, dilakukan sesudah dua minggu inkubasi, selanjutnya seperti metode direct plating, kultur diinkubasi pada suhu $30{ }^{\circ} \mathrm{C}$ selama satu minggu dan jumlah koloni dihitung, diisolasi dan dipurifikasi. Penyimpanan hasil purifikasi dilakukan menggunakan $25 \%$ gliserol dalam media marine agar.

Data berikut ini merupakan data makroskopik hasil isolasi bakteri simbion spons Callyspongia sp, dengan melihat warna, tekstur, bentuk, ukuran sel dan pertumbuhan koloni, merupakan indikator pengamatan dalam menentukan spesies mikrosimbion. Koloni bakteri yang diambil untuk diisolasi adalah koloni yang bentuk dan ukurannya sama serta tumbuh dominan. kedua koloni diidentifikasi dapat tumbuh baik pada pengenceran $10^{-2}-10^{-4}$, dari pertumbuhan seri pengenceran $10^{-1}$ sampai $10^{-}$ ${ }^{6}$, dilakukan pada Media Merine Agar (MA) sebagai media pertumbuhan bakteri karena sifatnya netral dan mengandung banyak nutrisi, yaitu yeast ekstrak sebagai sumber protein, sedangkan pepton sebagai sumber asam amino. Hasil isolasi mikrosimbion spons Callysponia sp ditunjukkan pada Gambar 3.1 berikut: 

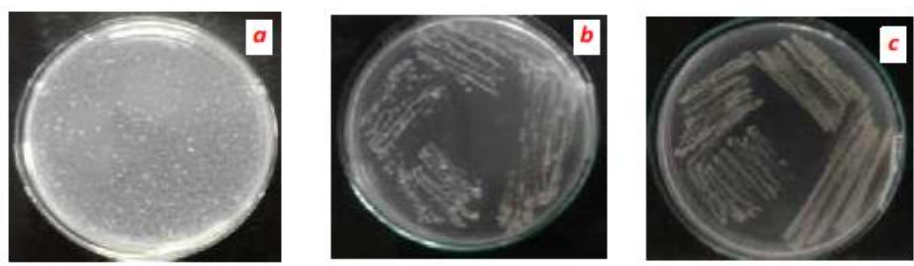

Gambar 3. 1. Hasil isolasi dan analisis morfologi spons Callyspongi sp. a) hasil isolasi dan penyebaran koloni bakteri; b) pertumbuhan koloni hasil purifikasi sebelum inkubasi pada media marine agar (MA); c) pertumbuhan koloni setelah inkubasi 1×24 jam.

Media yang digunakan untuk isolasi bakteri adalah media PCA (Plate Count Agar) sebagai media pertumbuhan karena mengandung banyak nutrisi yaitu yeast extract sebagai sumber karbon dan pepton sebagai sumber nitrogen. Hasil isolasi bakteri di tunjukkan pada Gambar 3. 2, berikut:

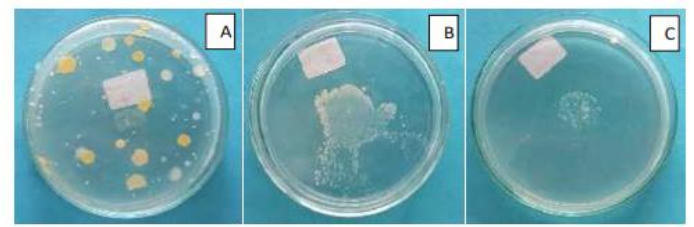

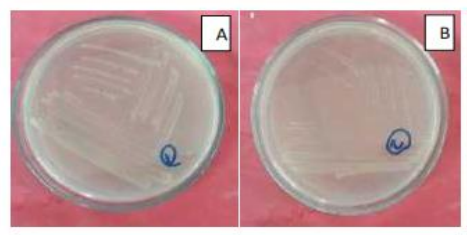

Isolat A

Isolat B

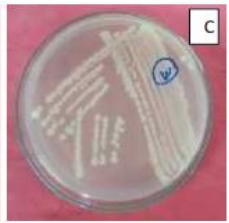

Isolat C

Gambar 3. 2, Hasil Isolasi bakteri a) Isolat bakteri sebelum dimurnikan b) Isolat murni

Isolat yang memiliki bentuk dan ukuran sama, selanjutnya dipurifikasi. Hasil purifikasi terhadap isolat mikrosimbion Callyspongia $s p$ diperoleh dua isolat tunggal dengan ciri berbeda dapat dilihat pada hasil analisis makroskopik dan mikroskopik Gambar 3. 3 berikut:
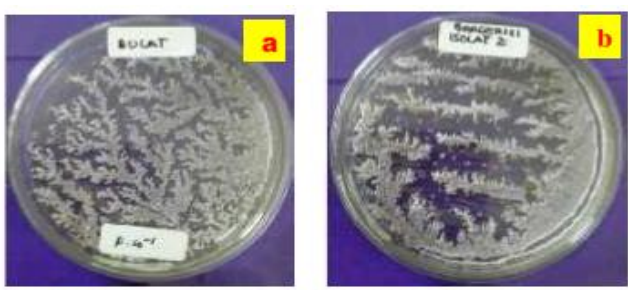

Gambar 3. 3. a) isolat 1: b) isolat 2. Kedua isolat tunggal hasil isolasi dan purifikasi, merupakan mikrosimbion spons Callyspongia sp asal Pantai Melawai Balikpapan, Kalimantan Timur. 
Hasil pengamatan morfologi di bawah mikroskop diperoleh dua macam isolat; dengan ciri-ciri isolat 1 , berbentuk bulat, warna krem yang melekat erat pada permukaan agar dan penyebaran koloni bergerombol, sedangkan isolat 2, bentuk batang, bergerigi, berwarna kecoklatan, koloni menyebar secara terpisah-pisah.

Ada 2 jenis isolat tunggal yang diperoleh setelah dilakukan purifikasi adalah cukup mederat dan rasional apabila dibandingkan dengan komposisi komponen penyusun biomassa spons yang didominasi oleh skeleton (spikula dan sel debris) dan sebagian kecil pellet bakteri.

Tabel 3. 2. Spesies Spons Hasil Isolasi dan jumlah isolat yang diperoleh serta kode Isolat

\begin{tabular}{|c|c|c|c|}
\hline No. & Spesies Spons & $\begin{array}{c}\text { Jumlah } \\
\text { Isolat }\end{array}$ & Kode Isolat per Jenis spons \\
\hline Sp la & $\begin{array}{l}\text { Petrosia (Strongylophora) } \\
\text { corticata }\end{array}$ & 3 & (Sp1.a. 1; Sp1.a.2; Sp1.a.3) \\
\hline Sp 2a & Niphates sp. & 3 & (Sp2.a1; Sp2.a.2; Sp2.a.3) \\
\hline Sp $3 a$ & Hyrtios erectus & 6 & $\begin{array}{l}\text { (Sp3.a.1; Sp3.a.2; Sp3.a.3; Sp3.a.4; } \\
\text { Sp3.a.5; Sp3.a.6) }\end{array}$ \\
\hline $\mathrm{Sp} 4 \mathrm{a}$ & Clathria (Thalysias) reinwardti & 1 & (Sp4.a.1) \\
\hline Sp 5a & Callyspongia $\mathrm{sp}$ & 2 & (Sp5.a.1; Sp5.a.2) \\
\hline Sp 6a & Aulleta sp & 3 & (Sp6.a.1; Sp6.a.2; Sp6.a.3) \\
\hline Sp 7a & Neopetrosia $\mathrm{sp}$ & 4 & (Sp7.a.1; Sp7.a.2; Sp7.a.3; Sp7.a.4) \\
\hline Sp 8a & Callyspongia aerizusa & 1 & (Sp8.a.1) \\
\hline Sp 1b & Callyspongia $\mathrm{sp}$ & 3 & (Sp 1b.1; Sp 1b.2; Sp 1b.3) \\
\hline Sp 2b & Chalinidae & 3 & (Sp 2b.1; Sp 2b.2; Sp 2b.3) \\
\hline Sp $3 b$ & $\begin{array}{l}\text { Callyspongia (Cladocalina) } \\
\text { vaginalis }\end{array}$ & 4 & (Sp 3b.41; Sp 3b.2; Sp 3b.3; Sp 3b.4) \\
\hline $\mathrm{Sp} 4 \mathrm{~b}$ & Chalinidae & 2 & (Sp 4b.1; Sp 4b.2) \\
\hline & 12 jenis spons & 35 & \\
\hline
\end{tabular}

Setiap jenis spons yang telah diisolasi dan purifikasi, selanjutnya dilakukan analisis morfologi, selanjutnya mikroorganisme simbion (bakteri simbion), dengan jumlah isolat yang ditemukan bervariasi untuk setiap jenis spons terhadap 12 jenis spons, sebagaimana dalam Tabel 3.2 di atas.

Bersadarkan Tabel 3. 2, di atas menunjukkan bahwa jumlah isolat yang bersimbion dengan suatu jenis spons bervariasi. Satu jenis spons dapat bersimbion dengan 6 macam isolat bakteri, namun spons jenis lain yang juga diperoleh pada lokasi yang sama justru hanya dapat bersimbion dengan 1 atau 2 jenis bakteri. Demikian pula sebaliknya satu jenis spons yang diperoleh pada dua atau tiga lokasi yang berbeda tidak menunjukkan jumlah dan jenis isolat bakteri simbion harus sama, hal ini disebabkan karena persoalan ketersediaan nutrisi pada suatu lokasi, adanya pencemaran dan kemampuan adaptasi spons tersebut terhadap lingkungan. 
Area perairan yang memiliki banyak predator terhadap spons akan menyebabkan mekanisme adaptasi spons berbeda dengan spons jenis yang sama akan tetapi ancaman predator relatif sedikit.

Uji pendahuluan 3 (tiga) jenis isolat, yakni isolat dari spons Niphates sp kode isolat, yakni (Sp2.a; Sp2.b; Sp2.c), terhadap limbah PAH jenis pyrene, menunjukkan hasil bahwa ketiga isolat tersebut mampu mendegradasi PAH dengan tingkat toksisitas sedang (4 buah anggota cincin), yang dilakukan kontak selama 20 hari tanpa melakukan variasi shaker, penambahan nutrisi dan dilakukan pada temperatur kamar. Hasil degradasi yang dilihat adalah kelimpahan pyrene sebelum dan setelah masa kontak yang diukur menggunakan instrument GC-MS. Hasil uji pendahuluan tersebut disimpulkan bahwa ketiga isolat yang diisolasi dari spons Niphates sp dapat mendegradasi PAH jenis pyrena.

Setiap isolat yang diperoleh dari hasil isolasi 8 jenis spons, selanjutnya dilakukan uji penotif berupa penentuan gram isolat dan uji biokimia dengan 12 parameter, yang bertujuan untuk mengetahui karakter dan perilaku dari setiap isolat. Beberapa langka analisis penotif baik pada penentuan gram isolat maupun pada uji biokimia. Isolat yang telah analisis secara penotif selanjutnya dilakukan analisis genotif untuk 23 jenis isolat untuk mendapatkan jenis bakteri dan strainnya dengan metode PCR. Data tentang spons pada saat pengambilan sampel, seperti $\mathrm{pH}$, salinitas, kedalaman dipadukan dengan data hasil analisis morfologi spons, serta data hasil isolasi agar dapat dilakukan analisis hubungan antara habitat spons dengan jenis mikrosimbion yang ada dan dinamika pertumbuhannya.

\section{4. Karakterisasi Mikrosimbion Spons}

Umumnya karakterisasi isolat bakteri dapat dilakukan dengan dua metode uji; yakni: pertama Uji pewarnaan dan Uji Biokimia yang sering disebut dengan identifikasi fenotip isolat; kedua adalah karakterisasi molekul gen 16S rRNA mikroorganisme yang sering disebut dengan analisis Genotif.

\section{4. 1. Metode Pewarnaan gram dan pengamatan morfologi isolat}

Identifikasi isolat bakteri metode pewarnaan gram, dilakukan dengan prosedur: 
1 Pengambilan biakan bakteri 1 ose pada objek glass yang sebelumnya telah dibebas-lemakkan dengan alkohol 96\%,

2 Biakan bakteri terpilih di tetesi Kristal violet (Gram A) 1-3 tetes dibuat hapusan, diamkan kemudian dicuci menggunakan aquadest

3 Dikeringkan, kemudian ditetesi larutan lugol (Gram B) 1-3 tetes, dibuat hapusan, diamkan,

4 Dicuci dan dikeringkan, lalu ditetesi dengan alkohol asetat (Gram C) 1-3 tetes lalu dibuat hapusan,

5 Diamkan, dan dicuci menggunakan aquadest dan dikeringkan, kemudian ditetesi safranin (Gram D), dibuat hapusan kemudian didiamkan,

6 Lalu dicuci menggunakan aquadest dan dikeringkan, setelah itu diamati di bawah mikroskop dengan pembesaran 10x.

\section{4. 2. Metode Permurnian dan Uji Biokimia isolat Mikrosimbion Spons}

Pertumbuhan dan perkembangan mikroba, memerlukan substrat yang disebut media. Media harus dalam keadaan steril. Susunan bahan, baik berbentuk bahan alami (seperti toge, kentang, daging, telur, wortel dan sebagainya) ataupun bahan buatan (berbentuk senyawa kimia baik organik ataupun anorganik) dipergunakan untuk pertumbuhan dan perkembangan mikroba. Medium adalah bahan yang digunakan untuk menumbuhkan mikroorganisme di atas atau di dalamnya.

Langkah awal yang dilakukan sebelum menumbuhkan mikroorganisme adalah dengan memahami kebutuhan dasar lalu mencoba memformulasikan satu media yang memberikan hasil terbaik. Persyaratan nutrient mikroorganisme sangat beragam, namun sebagai makhluk hidup mempunyai kebutuhan dasar meliputi air, karbon, energi, mineral dan faktor tumbuhan. Pemurnian mikroba dapat dilakukan dengan metode isolasi mikroba dan kultur murni. Isolasi mikroba adalah memindahkan mikroba dari lingkungannya dengan mengisolasi mikroba bakteri yang diperlukan atau dengan kata lain mikroba yang tidak kita butuhkan segera di singkirkan, sehingga diperoleh isolat murni atau biakan murni. Kultur murni adalah kultur yang sel-sel mikrobanya berasal dari pembelahan dari satu sel tunggal, artinya mikroba ditumbuhkan, kemudian kembangkan dari bakteri yang dihomogenkan. Bakteri di isolasikan agar didapatkan bakteri murni sesuai yang dibutuhkan. 
Mengisolasi mikroorganisme digunakan berbagai cara, antara lain dengan cara goresan (streak plate), cara taburan/tuang (pour plate) cara sebar (spread plate), cara pengenceran (dilution method), serta micromanipulator (teh micromanipulator method). Beberapa faktor yang diperhatikan dalam melakukan isolasi mikroba yaitu sebagai berikut:

1) Sifat setiap jenis mikroba yang akan diisolasi;

2) Tempat hidup atau asal mikroba tersebut;

3) Medium pertumbuhan yang sesuai;

4) Cara menginokulasi mikroba;

5) Cara inkubasi mikroba;

6) Cara menguji mikroba yang diisolasi berupa kultur murni dan sesuai yang dimaksud;

7) Cara memelihara agar mikroba yang telah diisolasi tetap merupakan kultur murni.

Upaya mencegah masuknya mikroorganisme yang tidak diinginkan dan untuk menanam suatu spesies terdapat beberapa cara yaitu:

1) Penanaman dengan penggoresan: cara ini untuk mengasingkan kuman agar didapatkan biakan murni;

2) Biakan agar tabung: biasanya dipergunakan untuk menunjukkan adanya pertumbuhan murni, mikro untuk aglutinasi gelas alas;

3) Biakan tusukan: biasanya dipergunakan untuk menunjukkan adanya pencairan gelatin dan mempertahankan biakan baru;

4) Biakan agar tuang: menunjukkan jumlah koloni mikroba hidup yang terdapat pada suspensi;

5) Biakan cairan: kegunaannya untuk menunjukkan biakan yang banyak dan cepat. Kerugiannya adalah tidak dapat membuat biakan murni dari bahan yang mengandung berbagai mikroorganisme.

Uji biokimia terhadap isolat dapat dilakukan dengan menggunakan beberapa pereaksi spesifik dengan parameter pengamatan secara umum yakni pada pembentukan endapan, perubahan warna, ada tidaknya pembentukan gas. Tabel 3.3. di bawah memperlihatkan parameter uji biokimia sebagai bagian dari analisis fenotif mikroorganisme, dimana terdapat 15 item uji standar. Setiap parameter uji memperlihatkan sifat dari mikroorganisme, sehingga karakter dan jenis mikroorganisme uji dapat di ketahui. Hal yang sama juga dapat dilihat pada Tabel 3.4, yang memlihatkan hasil uji biokimia menggunakan metode berdasarkan uji 
TSIA (Triple Sugar Iron Agar) terhadap isolat 1 dan 2 pada daerah slant warna media menjadi merah artinya isolat tersebut bersifat asam. Hal ini menandakan bahwa isolat ini mampu memfermentasi laktosa dan sukrosa. Pada daerah butt isolat 1 dan 2 bersifat basa menandakan isolat tersebut tidak dapat memfermentasi glukosa, namun jika media berubah menjadi kuning artinya besifat asam yang menandakan bahwa isolat tersebut mampu memfermentasi glukosa. Pembentukan gas hasil dari fermentasi $\mathrm{H}_{2}$ dan $\mathrm{CO}_{2}$ dapat dilihat dari pecahnya agar.

Secara umum standar uji biokimia mikroorganisme tidak terkecuali pada uji biokimi mikrosimbion spons laut yang terdiri atas 15 macam item dilakukan pada media berbeda, 15 macam standar uji biokimia dapat dilihat pada panduan pengamatan Tabel 3.3 berikut:

Tabel 3.3. Panduan pengamatan standar uji biokimia untuk mikroorganisme

\begin{tabular}{|c|c|c|c|c|c|c|}
\hline \multirow[b]{2}{*}{ Uji Biokimia } & \multirow[b]{2}{*}{ Media } & \multirow[b]{2}{*}{$\begin{array}{c}\text { Indikator } \\
\text { pengamatan }\end{array}$} & \multicolumn{4}{|c|}{ Reaksi } \\
\hline & & & $\begin{array}{c}\text { Isolat } \\
1\end{array}$ & $\begin{array}{c}\text { Isolat } \\
2 \\
\end{array}$ & $\begin{array}{c}\text { Isolat } \\
\mathbf{3} \\
\end{array}$ & $\begin{array}{c}\text { Isolat } \\
\text { dst }\end{array}$ \\
\hline Hidrolisa Pati & Agar Pati & & & & & \\
\hline Hidrolisa Kasein & Agar Susu & & & & & \\
\hline Indol & Kaldu tryptone & & & & & \\
\hline Reduksi Nitrat & Kaldu Nitrat & & & & & \\
\hline Fermentasi Glukosa & Kaldu Glukosa & & & & & \\
\hline Fermentasi Laktosa & Kaldu Laktosa & & & & & \\
\hline Fermentasi Sukrosa & Kaldu Sukrosa & & & & & \\
\hline Fermentasi Mannitol & Kaldu Mannitol & & & & & \\
\hline Sitrat & Agar S. Citrate & & & & & \\
\hline Katalase & NA Miring & & & & & \\
\hline Urease & Kaldu Urea & & & & & \\
\hline $\mathrm{H}_{2} \mathrm{~S}$ & Agar $\mathrm{H}_{2} \mathrm{~S}$ & & & & & \\
\hline Metil Merah & Kaldu R_yP & & & & & \\
\hline Voges Proskauer & Kalud $K-\mathrm{V} F$ & & & & & \\
\hline Hidrolisa Gelatin & Nutrien Gelatin & & & & & \\
\hline
\end{tabular}

Pembentukan gas $\mathrm{H}_{2} \mathrm{~S}$ ditandai dengan adanya endapan warna hitam. Pada isolat 1 dan 2, bertanda positif artinya terbentuk gas $\mathrm{H}_{2} \mathrm{~S}$ hal ini menandakan bahwa isolat tersebut mampu memfermentasi asam amino metionin dan sestein. Jika isolat mampu memfermentasi kedua asam amino ini maka gugus $\mathrm{S}$ akan keluar dan bereaksi dengan $\mathrm{H}_{2} \mathrm{O}$ membentuk $\mathrm{H}_{2} \mathrm{~S}$, dimana $\mathrm{H}_{2} \mathrm{~S}$ akan bereaksi dengan $\mathrm{Fe}^{2+}$ yang terdapat pada media membentuk FeS berwarna hitam dan mengendap.

Tabel 3.4, seperti pada uji MRVP (Methyl Red-Vogues Praskauer) untuk analisa MR isolat 1 dan 2, menunjukkan hasil positif karena media berubah menjadi merah setelah ditambahkan metil red artinya isolat ini menghasilkan asam campuran (metilen glikon) dari proses fermentasi glukosa yang terkandung dalam media MR. Sedangkan isolat 1 dan 2, 
juga menunjukkan hasil positif karena warna media berubah jauh dari warna media. Untuk analisa VP, kekedua isolat juga menunjukkan hasil positif karena terbentuk warna merah setelah ditambahkan $\alpha$ naphtol dan $\mathrm{KOH}$ artinya hasil akhir fermentasi isolat ini dapat berupa asetil metil karbinol (asetoin).

Tabel 3. 4. Contoh hasil analisis fenotip melalui karakterisasi isolat metode uji biokimia

\begin{tabular}{|c|c|c|c|c|}
\hline \multirow[b]{2}{*}{ Uji Biokimia } & \multirow[b]{2}{*}{ Media } & \multirow{2}{*}{$\begin{array}{c}\text { Indikator Perubahan Warna } \\
\text { pada Media }\end{array}$} & \multicolumn{2}{|c|}{ Reaksi } \\
\hline & & & Isolat 1 & Isolat 2 \\
\hline Hidrolisa Pati & Agar Pati & $\begin{array}{l}+ \text { media tampak jernih/bening } \\
- \text { Media keruh }\end{array}$ & + & + \\
\hline $\begin{array}{l}\text { Hidrolisa } \\
\text { Kasein }\end{array}$ & Agar Susu & $\begin{array}{l}+ \text { zona berwarna bening di sekitar } \\
\text { pertumbuhan bakteri } \\
\text { - tidak terbentuk zona bening }\end{array}$ & td & td \\
\hline Indol & $\begin{array}{l}\text { Kaldu } \\
\text { tryptone }\end{array}$ & $\begin{array}{l}+ \text { ada cincin berwarna merah pada } \\
\text { bagian atas suspensi bakteri } \\
\text { - tidak ada cincin merah }\end{array}$ & + & + \\
\hline Reduksi Nitrat & Kaldu Nitrat & $\begin{array}{ll}+ & \text { tidak ada perubahan warna } \\
\text { - } & \text { kaldu berwarna merah } \\
\end{array}$ & td & td \\
\hline $\begin{array}{l}\text { Fermentasi } \\
\text { Glukosa }\end{array}$ & $\begin{array}{l}\text { Kaldu } \\
\text { Glukosa }\end{array}$ & \multirow{2}{*}{$\begin{array}{l}+ \text { fenol merah pada media berubah } \\
\text { menjadi kuning, dan terbentuk gas } \\
\text { pada Tabung Durham }\end{array}$} & - & - \\
\hline $\begin{array}{l}\text { Fermentasi } \\
\text { Laktosa }\end{array}$ & Kaldu Laktosa & & - & - \\
\hline $\begin{array}{l}\text { Fermentasi } \\
\text { Sukrosa }\end{array}$ & Kaldu Sukrosa & \multirow{2}{*}{$\begin{array}{l}\text { - warna tetap merah, dan tidak } \\
\text { terbentuk gas }\end{array}$} & - & - \\
\hline $\begin{array}{l}\text { Fermentasi } \\
\text { Mannitol }\end{array}$ & $\begin{array}{l}\text { Kaldu } \\
\text { Mannitol }\end{array}$ & & + & + \\
\hline Sitrat & $\begin{array}{l}\text { Agar S. } \\
\text { Citrate }\end{array}$ & $\begin{array}{l}+ \text { media berwarna biru Keunguan } \\
\text { - media tetap berwarna hijau }\end{array}$ & - & + \\
\hline Katalase & NA Miring & $\begin{array}{l}\text { gelembung udara pada koloni } \\
\text { - } \quad \text { tidak ada gelembung udara } \\
\end{array}$ & + & - \\
\hline Urease & Kaldu Urea & $\begin{array}{l}+ \text { media berwarna merah muda gelap } \\
-\quad \text { media tetap berwarna merah }\end{array}$ & - & - \\
\hline $\mathrm{H}_{2} \mathrm{~S}$ & Agar $\mathrm{H}_{2} \mathrm{~S}$ & $\begin{array}{l}\text { + daerah tusukan inokulasi berwarna } \\
\text { hitam } \\
\text { - tidak ada perubahan warna }\end{array}$ & + & + \\
\hline Metil Merah & \multirow[b]{2}{*}{ Kaldu R-VP } & $\begin{array}{l}+ \text { ada cincin berwarna merah pada } \\
\text { bagian atas suspensi bakteri } \\
\text { - ada cincin berwarna kuning }\end{array}$ & + & + \\
\hline $\begin{array}{l}\text { Voges } \\
\text { Proskauer }\end{array}$ & & $\begin{array}{l}+ \text { ada cincin berwarna merah } \\
\text { muda pada bagian atas suspensi } \\
\text { bakteri } \\
\text { - } \quad \text { tidak ada cincin merah muda }\end{array}$ & + & + \\
\hline $\begin{array}{l}\text { Hidrolisa } \\
\text { Gelatin }\end{array}$ & $\begin{array}{l}\text { Nutrien } \\
\text { Gelatin }\end{array}$ & $\begin{array}{l}\text { media berubah menjadi fasa semi- } \\
\text { cair (gelatin) } \\
\text { - media tetap dalam fasa cair }\end{array}$ & + & - \\
\hline \multicolumn{2}{|c|}{ Kesimpulan jenis bakteri untuk } & \begin{tabular}{l|l} 
Isolat 1 & Golongan Bacillus \\
Isolat 2 & Golongan Bacillus \\
\end{tabular} & & \\
\hline
\end{tabular}

Pada uji indol terhadap isolat 1 dan 2, menunjukkan hasil positif karena terbentuk cincin berwarna merah muda, berarti kedua isolat tersebut memiliki indol dari tryptopan sebagai sumber karbon. Asam amino tryptopan merupakan komponen asam amino yang lazim terdapat pada protein sehingga asam amino ini dengan mudah dapat digunakan oleh mikroorganisme akibat penguraian protein. 
Berdasarkan uji sitrat terhadap isolat 1 dan 2, hasil reaksinya negatif untuk isolat 1, karena tidak terjadi perubahan warna pada media menununjukkan isolat tersebut tidak mempunyai enzim sitrat permease yaitu enzim spesifik yang membawa sitrat ke dalam sel. Sehingga isolat tersebut tidak menggunakan sitrat sebagai satu-satunya sumber karbon, sedangkan isolat 2, hasil positif karena terjadi perubahan warna dari hijau ke biru, berarti isolat ini mampu menggunakan karbon pada media sitrat sebagai sumber karbon.

Hasil reaksi pada uji urease terhadap isolat 1 dan 2, menunjukkan hasil negatif karena tidak terjadi perubahan warna pada media berarti isolat ini tidak mampu menghidrolisis urea, artinya ketiga isolat tersebut tidak memiliki enzim urease yang dapat menguraikan urea membentuk amoniak. Hasil uji fermentasi menggunakan pereaksi glukosa, laktosa dan sukrosa terhadap kedua isolat memberikan hasil negatif karena tidak terjadi perubahan warna dari merah ke kuning hal ini menunjukkan bahwa media tidak dapat memfermentasi gula, sedangkan untuk uji mannitol terhadap kedua isolat menunjukkan hasil positif karena terjadi perubahan warna dari merah ke kuning menunjukkan bahwa isolat tersebut memfermentasi gula membentuk asam.

\section{4. 3. Metode Penentuan Spesies Isolat dengan Metode Polimerase Chain Reaction (PCR) (Metode Genotif)}

\section{a. Ekstraksi DNA Isolat bakteri simbion spon}

Disiapkan tabung eppendorf bersih, lalu dimasukkan $200 \mu \mathrm{L}$ suspensi isolat dan ditambahkan $800 \mu \mathrm{L}$ PBS 1x, kemudian disimpan pada suhu $4{ }^{\circ} \mathrm{C}$ selama 5 menit, lalu disentrifugasi pada kecepatan 10.000 rpm selama 10 menit dalam suhu kamar, supernatan yang terbentuk dibuang, ditambahkan kembali $500 \mu \mathrm{L}$ PBS 1x, disentrifugasi pada kecepatan $4.000 \mathrm{rpm}$ selama 5 menit pada suhu kamar, supernatan yang terbentuk dibuang (sentrifugasi pada kecepatan 4000 rpm dilakukan sebanyak 3 kali pengulangan), kemudian suspensi ditambahkan $50 \mu \mathrm{L} \quad \mathrm{ddH}_{2} \mathrm{O}$, dihomogenkan, selanjutnya dipanaskan dalam air mendidih selama \pm 10 menit pada suhu kamar, lalu disentrifugasi kembali pada suhu kamar selama 10 menit dengan putaran $10.000 \mathrm{rpm}$, supernatan dipindahkan dalam tabung eppendorf yang baru, isolat sampel DNA siap dicampur dengan 
pereaksi dalam proses PCR untuk di ukur dengan PCR, (Prosedur di atas dikerjakan aseptik).

\section{b. Percampuran komponen pereaksi PCR}

Disiapkan tabung $0,2 \mathrm{~mL}$ dan dimasukkan $20 \mu \mathrm{L}$ PCR mix ke dalam tabung, kemudian ditambahkan primer Forward dan reverse masing-masing $0,5 \mu \mathrm{L}$, kemudian ditambahkan $4 \mu \mathrm{L}$ sampel sehingga volume campuran menjadi $\pm 24,7 \mu \mathrm{L}$. (Prosedur di atas dikerjakan aseptik).

\section{c. Running Polimerase Chain Reaction (PCR)}

Prinsip kerja running PRC dalam reaksi pelipatgandaan suatu fragmen DNA berlangsung dalam 3 kali siklus yakni, siklus pertama, dimulai dengan denaturasi DNA, sehingga DNA terpisah dan menjadi tunggal dilakukan pada suhu $95{ }^{\circ} \mathrm{C}$ selama 2 menit; siklus kedua terjadi penempelan primer (anneling) pada suhu $65{ }^{\circ} \mathrm{C}$ berlangsung selama 2 menit, sehingga primer membentuk jembatan hidrogen pada cetakan di daerah sekuen. Tahapan selanjutnya adalah extension, yaitu DNA polimerase melakukan proses polimerase rantai baru berdasarkan informasi pada DNA cetakan, (proses berlangsung pada suhu $72{ }^{\circ} \mathrm{C}$ dalam waktu 2 menit); dan siklus ke tiga terjadi pada suhu $72{ }^{\circ} \mathrm{C}$ selama 10 menit, dimana rantai DNA baru akan membentuk jembatan hidrogen dengan DNA cetakan, sehingga diperoleh \pm 123 pasangan basa nitrogen atau base pair (bp), (Prosedur di atas dikerjakan aseptik). Maksud dari aseptik adalah dapat dijamin bahwa spesies isolat betul-betul murni spesies isolat dari bahan yang akan ditentukan, bukan dari spesies karena kemungkinan ada kontaminasi.

\section{4. 4. Penentuan jumlah koloni suspensi bakteri dan biomassa spons}

Misalnya lima jenis isolat yang akan ditentukan julah selnya sebelum digunakan dalam berbagai aplikasi tertentu, maka hendakn jumlah sel setiap jenis isolat harus diketahui, bertujuan untuk dapat melakukan analisis terhadap kenirja isolat dalam suatu aplikasi tertentu. Misalnya dibuat 5 macam suspensi dari isolat yang telah diisolasi dari satu jenis spons tertnetu, yakni; suspensi isolat Bacillus subtilis strain BAB1684 (BS), suspensi isolat Bacillus flexus strain PHCDB20 (BF), suspensi isolat bakteri campuran BSF (perbandingan volume 1:1), suspensi sel 
biomassa spons Callyspongia sp (BM) dan suspensi kontrol menggunakan Pseudomonas sp murni (KP). Volume masing-masing suspensi dibuat sebanyak $500 \mathrm{~mL}$. Suspensi BS dibuat dengan prosedur:

\section{Cara Membuat suspensi Bakteri dan biomassa spons}

1. Memasukkan $\pm 2 \mathrm{~mL}$ larutan $\mathrm{NaCl} 0,9 \%$ fisiologis ke dalam tabung reaksi yang berisi isolat $\mathrm{BS}$;

2. Kocok, diperkirakan semua koloni BS larut diperoleh suspensi pekat, kemudian suspensi tersebut diencerkan dengan memasukkan dalam labu takar $500 \mathrm{~mL}$ yang sebelumnya telah diisi larutan $\mathrm{NaCl} 0,9 \%$ fisiologis;

3. Dihomogenisasikan dan volume diimpitkan hingga tanda batas, dikerjakan steril menggunakan sarung tangan, masker dan dikerjakan dalam LAF.

4. Dibuat suspensi BS, BF, BSF, BM dan KP menggunakan prosedur sama seperti di atas.

3. 4. 5. Penentuan jumlah sel bakteri masing-masing suspensi yang akan digunakan untuk Aplikasi dalamMetode degradasi limbah sludge minyak bumi (SMB)

Jumlah koloni bakteri untuk setiap suspensi yang akan digunakan untuk mendegradasi limbah sludge minyak bumi dihitung dengan prosedur sebagai berikut:

Jumlah koloni suspensi BS ditentukan dengan cara: (contoh- tentatip):

1 Disiapkan 6 buah tabung reaksi steril diberi label pengenceran P.10 ${ }^{-1}$, P. $10^{-2}$, P. $10^{-3}$, P. $10^{-4}$, P. $10^{-5}$, dan P. $10^{-6}$.

2 Tabung reaksi tersebut masing-masing diisi $900 \mu \mathrm{L}$ larutan $\mathrm{NaCl}$ 0,9\% fisiologis.

3 Suspensi BS diencerkan dengan mengambil $100 \mu \mathrm{L}$ dari labu takar 500 $\mathrm{mL}$ kemudian dimasukkan ke dalam tabung reaksi $\left(\mathrm{P} .10^{-1}\right)$, dikocok, kemudian dipipet $100 \mu \mathrm{L}$ suspensi BS dari tabung reaksi I dan dimasukkan ke dalam tabung reaksi (P.10-2), dan seterusnya sampai tabung reaksi ke P.10 $10^{-6}$. Disiapkan pula 6 buah cawan petri steril diberi label pengenceran P.10 $10^{-1}$, P.10 $0^{-2}$ P. $10^{-3}$, P. $10^{-4}$, P. $10^{-5}$, dan P. $10^{-6}$.

Suspensi BS dalam tabung reaksi setiap pengenceran dipipet sebanyak $100 \mu \mathrm{L}$, dan disebar pada cawat petri secara merata sesuai label 
pengenceran, setiap cawan petri yang telah berisi masing-masing $100 \mu \mathrm{L}$ suspensi BS, ditambahakna masing-masing $15 \mathrm{~mL}$ media Marine Agar (MA), ditutup dan dibiarkan memadat, kemudian dibungkus dengan kertas dan diinkubasi 2x24 jam. Jumlah koloni dihitung. Perlakuan yang sama untuk penyiapan suspensi BF, BSF, BM dan KP ditentukan dengan mengikuti prosedur b di atas, (Prosedur di atas dikerjakan aseptik). Jumlah sel bakteri setiap jenis suspensi yang digunakan pada setiap cawan petri dihitung menggunakan rumus:

$$
\mathrm{N}=\Sigma \mathrm{C} /(\mathrm{V} \times 1,1 \times \mathrm{d})
$$

Keterangan :

TBUD $=$ Terlalu Banyak Untuk Dihitung (standar $\leq 300$ ).

$\Sigma \mathrm{C}=$ jumlah sel bakteri yang dihitung pada 2 cawan petri berurutan (pengencran $10^{-1}$ dan $10^{-2}$ ) dengan jumlah minimum sel bakteri 30/cawan dan maksimum 300/cawan

$\mathrm{V}=$ volume inokulum yang dimasukan ke dalam setiap cawan petri

$\mathrm{D}=$ pengenceran pertama yang dilakukan

Pertumbuhan bakteri diamati dengan penghitungan jumlah sel bakteri setelah inkubasi 24 jam dengan menggunakan rumus :

$$
\mathrm{BO}=\mathrm{D} \text { X C, }
$$

Keterangan

$\mathrm{BO}=$ jumlah sel bakteri $/ \mathrm{ml}$

$\mathrm{D}=$ faktor pengenceran

$\mathrm{C}=$ jumlah koloni bakteri

Persamaan 1, digunakan untuk menghitung jumlah sel bakteri, sedangkan persamaan 2 digunakan untuk mengetahui pertumbuhan bakteri atau isolat. Dalam melakukan penerapan dari kedua persamaan di atas untuk mengetahui jumlah sel dan pertumbuhannya sel bakteri, biasanya dilakukan untuk isolat yang telah dilakukan pengenceran yang umum dilakukan pada pengenceran $10^{-5}$ sampai dengan $10^{-7}$, tergantung pada sel yang terbentuk pada setiap pengenceran, apakah sudah dapat dihitung atau masih sangat banyak yang bertindihan sehingga diperlukan pengenceran lebih lanjut pada tingkat konsentrasi sepersepuluh berikutnya. 


\section{Bab -4- \\ KARAKTERISASI SPONS}

\subsection{Analisis Biomassa Spons}

Biomassa spons adalah bahan atau material biologi yang hidup atau yang berasal dari yang hidup diperoleh dari bagian tertentu spons atau bahan yang baru mati yang dapat digunakan sebagai sumber bahan bakar ataupun sebagai bahan aktif dalam proses produksi atau dalam proses lainnya seperti proses perombakan material tertentu bias dengan destruksi, degradasi, reduksi atau metode lainnya yang sejenis. Biomassa spons dalam jumlah akumulasi sangat kecil, yang diperoleh melalui proses pemisahan dengan metode sentrifugasi.

Hasil pemisahan tersebut disebut fraksi. Fraksi sel spons diperoleh dengan pengamatan menggunakan prefarat histologi sel spons. Gambar 4.1, berikut menunjukan distribusi fraksi sel spons hasil sentrifugasi

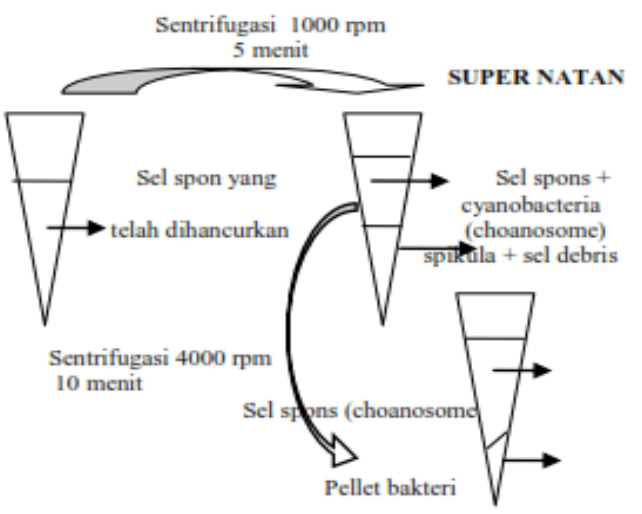

Gambar 4.1. Sebaran fraksi sel spons hasil sentrifugasi

Berdasarkan gambar di atas yang menunjukkan bagaimana proses fraksinasi sel spons yang diawali dengan penghancuran sel spons menggunakan blender, lalu di sentrifugasi selama kurang lebih 5 menit pada putaran $1000 \mathrm{rpm}$. Fraksi yang diperoleh berupa campuran sel spons, cyanobakteria, spicula dan sel debris. Supernatan tersebut selanjutnya di sentrifugasi pada putaran $4000 \mathrm{rpm}$ selama 15 menit dan diperoleh dua jenis ekstrak yakni sel spons (cyanobakteria) pada bagian atas dan pellet bakteri pada bagian bawah. Gambar 4.2 berikut, memperlihatkan struktur sel spons petrosia $\mathrm{sp.}$ 

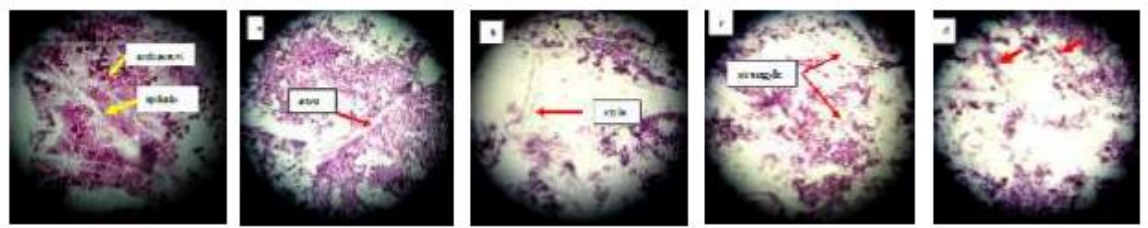

Gambar 4.2. Struktur sel spons Petrosia sp. (a,b,c) adalah spikula pembesaran 200x, dan (d) merupakan medulla spons pembesaran 400x

Komposisi biomassa Sel Spons Petrosia sp hasil fraksinasi sel spons dengan metode sentrifugasi menunjukkan bahwa bobot spikula dan sel debris 68,7 \%; sel spons (choanosome) 19,7\%, dan pellet bakteri simbion $11,7 \%$, sedangkan komposisi biomassa spons A. aaptos terdiri atas $55,9 \%$ bobot total sel, sel spons $14,2 \%$, dan pellet bakteri simbion mencapai sekitar 29,9\%. Hasil fraksi sel spons Petrosia sp dengan menggunakan metode sentrifugasi menunjukkan bahwa fraksi spikula dan sel debris spons merupakan fraksi yang dominan sedangkan pellet bakteri simbion dengan jumlah paling kecil. Hal ini mengindikasikan bahwa biomassa spons Petrosia sp lebih dipengaruhi oleh sel-sel penyusun skeleton spons, daripada bobot simbionnya. Hal ini disebabkan fraksifraksi sel tersebut bersifat transparan, sehingga sulit untuk diamati. Oleh karena itu sangat menarik untuk dilakukan studi lanjutan dengan menggunakan reagent pewarna yang sesuai dan menggunakan mikroskop dengan resolusi yang lebih tinggi seperti mikroskop elektron. Dengan demikian data yang diperoleh lebih terperinci, dan diharapkan bisa menjadi batu loncatan untuk mempelajasri mekanisme asosiasi bakteri simbion dan pengaruhnya terhadapp produksi senyawa bioaktif spons.

Spons Callyspongia sp dengan komposisi susunan biomassa diperoleh komponen berupa fraksi skeleton seperti spikula dan sel debris mencapai 69, $8 \%$; fraksi sel spons (choanosome) 18, $8 \%$; dan pellet bakteri 11, $3 \%$. Komposisi fraksi sel biomassa spons Callyspongia sp. tersebut menunjukkan bahwa komposisi sel biomassa didominasi oleh fraksi skeleton, dimana komponen skeleton dominan dipengaruhi oleh morfologi. Struktur morfologi spons dengan fraksi spikula dan debris berisi spongin sangat dominan yang menyebabkan morfologi spons Callyspongia sp. lebih kaku dan kandungan spikula padat meskipun tidak memiliki microscleres. 
Hal ini menyebabkan morfologi spons Callyspongia sp dan A. aaptos yang lebih kaku dan mengandung spikula yang tersebar secara padat. Susunan spikula tersebut terdiri dari spikula oxea, style dan strongyle. Spikula ini terutama ditemukan tersebar pada lapisan ektosom. Sementara itu, sel archaeocyte pada lapisan mesohyl tidak terlihat dengan jelas, dan hanya dalam jumlah yang tidak terlalu banyak. Persentase fraksi pellet bakteri simbion yang rendah dapat mendukung teori bahwa spons ini hanya mengandung bakteri simbion dalam jumlah kecil. Selain itu, pengamatan histologi juga menunjukkan serat spongin yang berlimpah, mendukung terciptanya morfologi yang keras dan padat (kasar). Jika sebagian atau keseluruhan spikula bersilika ditutupi oleh serat spongin ini, maka struktur spons akan menjadi lebih kaku. Dengan demikian, dapat dikatakan bahwa biomassa spons Petrosia sp. lebih dipengaruhi oleh selsel spons dan komponen penyusun skeleton. Yang menunjukkan bahwa spons Petrosia sp yang hidup pada daerah yang subur atau kaya bahan nutrient.

Penentuan komponen penyusun biomassa spons dilakukan hanya pada tiga jenis spons, yakni Callyspongia sp Petrosia sp dan A. aaptos menggunakan metode histomorfology. Sel spons tersebut selanjutnya dipreparasi sampai diperoleh mikrosimbion dan biomassa yang dijadikan sebagai material pendegradasi limbah sludge minyak bumi. Ketiga jenis spons tersebut dipilih karena letak pertumbuhan di kedalaman laut dangkal. Spesies terpilih selanjutnya ditentukan komponen penyusun biomassa.

Fraksi pellet bakteri yang rendah menunjukkan bahwa spons tersebut hanya mengandung bakteri simbion yang sedikit. Spons yang hidup pada daerah yang subur dan kaya bahan organik, memiliki biomassa sel yang tinggi namun hanya mengandung sedikit bakteri simbion karena tersediahnya cukup nutrisi untuk pertumbuhan, sehingga simbion mikroba (bakteri) tidak terlalu dibutuhkan dalam mekanisme adaptasi fisiologi spons.

Komposisi biomassa spons Callyspongia sp yang diperoleh bersesuaian dengan kondisi titik sampling spons mengindikasikan bahwa ancaman lingkungan terhadap kehidupan spons khususnya Callyspongia $s p$ yang hidup pada Pantai Melawai Balikpapan tidak terlalu ekstrim, sehingga jumlah bakteri simbion tidak banyak. Tujuan utama simbion 
bakteri dengan spons untuk kepentingan pertahanan dan perlindungan diri dari ancaman lingkungan ekstrim, agar spons tersebut tetap hidup. Jumlah fraksi pellet bakteri penyusun suatu jenis spons sangat dipengaruhi oleh habitat spons, jika merasa terancam, maka spons akan berusaha untuk mendapatkan perlingdungan dari sejumlah simbion bakteri. Kelimpahan skeleton dan sel bakteri sebagai komponen penyusun biomassa spons sangat dipengaruhi oleh temperatur, iklim, zat organik, dan tingkat fotosintesis. Skeleton yang dominan mengindikasikan bahwa jumlah dan jenis mikrosimbion pada spons tidak melimpah dan variasi yang terbatas. Kepastian jumlah dan jenis mikrosimbion spons Callyspongia sp dapat dilakukan melalui isolasi-purifikasi, uji fenotip (pewarnaan gram dan uji biokimia isolat) serta uji genotip molekul gen rRNA.

\section{2. Analisis Fenotip Spons}

\section{2. 1. Analisis Fenotip Metode Pewarnaan gram Isolat Tunggal}

Analisis fenotip melalui pewarnaan gram isolat tunggal yang diperoleh setelah purifikasi untuk menentukan kelompok gram mikrosimbion. Tabel 4.1 berikut menunjukkan salah satu contoh hasil pengamatan mikrosimbion spons Callyspongia sp yang diperoleh dari Pulau Kodingareng Keke Kepulauan Spermonde, dimana spons tersebut hasil isolasi yang diperoleh dua jenis mikrosimbion (isolat 1 dan isolat 2). Data hasil pengamatan diasjikan sebagai berikut:

Tabel 4. 1. Hasil analisis mikroskopik dengan pewarnaan gram bakteri simbion spons Callyspongia sp

\begin{tabular}{|l|l|l|}
\hline \multicolumn{1}{|c|}{ Pengamatan } & \multicolumn{1}{c|}{ Isolat 1 } & \multicolumn{1}{c|}{ Isolat 2 } \\
\hline Warna & biru-ungu & ungu \\
\hline Bentuk & Batang & basil \\
\hline Reagent Safranin & warna tetap & Warna tetap \\
\hline Endospora & Ada, kurang jelas & Ada, kurang jelas \\
\hline Terhadap alkali $(1 \% \mathrm{KOH})$ & Tidak larut & Tidak larut \\
\hline Simpulan & gram positif & gram positif \\
\hline
\end{tabular}

Mencermati data Tabel 4.1, di atas, disimpulkan bahwa isolat mikrosimbion spons Callyspongia sp adalah kelompok bakteri gram positif, berdasarkan hasil analisis makroskofik terhadap isolat 1, yaitu sel bakteri berbentuk batang permukaan rata, koloni terpisah, warna tetap setelah ditambahkan reagen gram D (safranin), dan tidak memperlihatkan 
adanya lendir setelah penambahan alkali $1 \% \mathrm{KOH}$, sedangkan isolat 2, bentuk sel bulat, permukaan rata dan koloni terpisah, warna tetap setelah ditambahkan safranin dan tidak memperlihatkan pelarutan setelah penambahan alkali $1 \% \mathrm{KOH}$. Pada penambahan reagen D (Safranin), teramati tidak ada perubahan warna kedua isolat disebabkan karena dinding sel kedua isolat berupa rantai peptida yang tebal, sehingga reagen safranin atau air fuchsin tidak dapat menembus dinding sel yang tebal. Bakteri gram positif tidak memiliki lapisan lemak yang melimpah sehingga pada saat pemberian alkali $1 \% \mathrm{KOH}$ tidak menunjukkan adanya lendir yang dapat larut.

Proses isolasi di tiga titik sampel, didapatkan 3 isolat bakteri yang berbeda. Kemurnian isolat dideteksi menggunakan mikroskop perbesaran 1000X dengan mengamati bentuk dan warna selnya. Hasil mikroskopis pewarnaan gram ditunjukkan pada Gambar 4. 3, berikut:
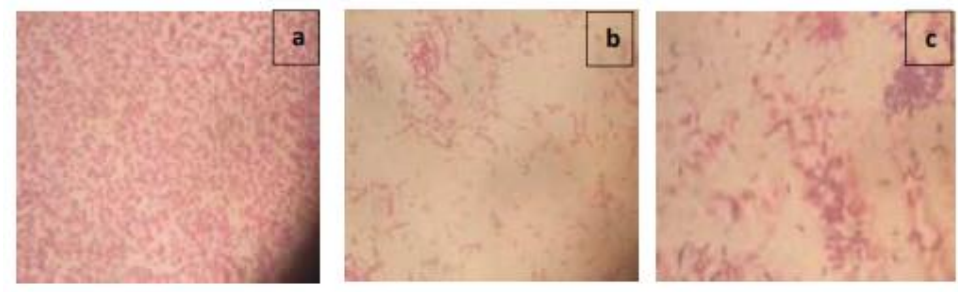

Gambar 4. 3. Contoh hasil analisis mikroskopis dengan pewarnaan gram $a=i$ isolat $A, b=$ isolat $\mathrm{B}, \mathrm{c}=$ isolat $\mathrm{C}$, yang merupakan isolat hasil isolasi dri spons Petrosia sp

Hasil analisis mikroskopis pada Gambar 4.3 dapat dilihat isolat (a) dan (b) merupakan gram negatif sedangkan isolat (c) merupakan gram positif. Berdasarkan data hasil pewarnaan gram, dimana setelah pengamatan dengan mikroskop tampak warna merah pada isolat $\mathrm{A}$ dan $\mathrm{B}$, sedangkan isolat $\mathrm{C}$ berwarna biru-ungu. Mikroorganisme merupakan subjek dalam biodegradasi sehingga proses biodegradasi sangat dipengaruhi oleh aktivitas mikroorganisme tersebut. Pada kondisi yang memungkinkan, yaitu dengan adanya karbon, sumber energi dan nutrien yang cukup, bakteri dapat meningkatkan jumlahnya dengan cara membelah diri. Pada proses ini, satu sel bakteri dapat membelah menjadi dua sel. Dua sel tersebut kemudian membelah lagi menjadi empat dan seterusnya. Waktu yang dibutuhkan bakteri untuk membelah diri disebut waktu generasi (generation time). Bakteri memiliki waktu generasi yang singkat, umumnya dalam hitungan menit, jam, hari ataupun minggu. 
Populasi bakteri dapat berganda dalam setiap generasinya, sehingga jumlah bakteri dapat meningkat dalam laju yang cepat.

Kurva pertumbuhan bakteri dibagi dalam empat fase pertumbuhan. yaitu:

\section{Fase penyesuaian (lag phase)}

Setelah inokulasi, terjadi peningkatan ukuran sel, mulai pada waktu sel tidak atau sedikit mengalami pembelahan. Fase ini, ditandai dengan peningkatan komponen makromolekul, aktivitas metabolik, dan kerentanan terhadap zat kimia dan faktor fisik. Fase lag merupakan suatu periode penyesuaian yang sangat penting untuk penambahan metabolit pada kelompok sel, menuju tingkat yang setaraf dengan sintesis sel maksimum. Lamanya fase ini bergantung pada kondisi pertumbuhan bakteri.

2. Fase pertumbuhan eksponensial (logarithmic phase)

Pada fase ini, sel bakteri mengalami proses pembelahan diri dengan laju yang sesuai dengan kemampuannya dalam menyerap nutrisi dari lingkungan. Populasi bakteri bertambah dengan laju pertumbuhan maksimum dan berlipat ganda sebagai fungsi dari waktu generasinya. Karena kecepatan pembelahan diri relatif konstan, maka tahap ini paling cocok untuk menetapkan kecepatan pembelahan diri atau disebut juga laju pertumbuhan.

3. Fase pertumbuhan stasioner (stationary phase)

Fase stasioner ditandai dengan terhentinya pertumbuhan dari selsel. Kecepatan pertumbuhan tergantung dari kadar substrat, oleh karena itu menurunnya kecepatan pertumbuhan sudah terjadi ketika kadar substrat berkurang sebelum substrat habis terpakai. Dengan demikian pengalihan dari fase eksponensial ke fase stasioner terjadi berangsungangsur. Faktor-faktor lain yang menyebabkan menurunnya kecepatan pertumbuhan antara lain kepadatan populasi yang tinggi, tekanan parsial oksigen yang rendah dan timbunan produk metabolisme yang toksik.

4. Fase kematian

Fase kematian ditandai dengan berkurangnya jumlah sel hidup (viable) dalam media akibat terjadinya kematian (mortalitas). Jumlah sel hidup dapat berkurang secara eksponensial. Hal ini disebabkan karena media kehabisan nutrient. 
Tipe pertumbuhan bakteri tidak berlangsung dalam periode waktu yang kontinyu, namun dipengruhi oleh lingkungan dan nutrisi yang terkandung didalamnya. Nutrisi ini sangat mempengaruhi pertumbuhan bakteri. Kurang nutrisi dapat menyebabkan berhentinya pertumbuhan bakteri. Pertumbuhan bakteri dapat digambarkan dalam kurva pertumbuhan.

\section{2. 2. Analisis fenotip melalui uji biokimia isolat}

Fenotip adalah suatu karakteristik struktur biokimiawi, fisiologi dan perilaku yang dapat diamati dari suatu organisme/mikroorganisme yang diatur oleh genotip dan lingkungan, serta hasil interaksi diantara keduanya. Eksfektasi fenotip dapat dilihat dari warna rambu, warna mata, berat badan dan fisiologis lainnya dari suatu organisme.

Tabel 4.2. Hasil karakterisasi isolat mikrosimbion spons Callyspongia sp melalui uji biokimia

\begin{tabular}{|c|c|c|c|}
\hline \multirow[b]{2}{*}{ Parameter uji biokimia } & \multirow[b]{2}{*}{ Media } & \multicolumn{2}{|c|}{ Hasil reaksi } \\
\hline & & 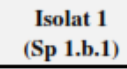 & $\begin{array}{c}\begin{array}{c}\text { Isolat 2 } \\
\text { (Sp. 1.b.2) }\end{array} \\
\end{array}$ \\
\hline Hidrolisa Pati & Agar Pati & + & + \\
\hline Hidrolisa Kasein & Agar Susu & td & td \\
\hline Indol & Kaldu tryptone & + & + \\
\hline Reduksi Nitrat & Kaldu Nitrat & td & td \\
\hline Fermentasi Glukosa & Kaldu Glukosa & - & - \\
\hline Fermentasi Laktosa & Kaldu Laktosa & - & - \\
\hline Fermentasi Sukrosa & Kaldu Sukrosa & - & - \\
\hline $\begin{array}{l}\text { Fermentasi } \\
\text { Mannitol }\end{array}$ & Kaldu Mannitol & + & + \\
\hline Sitrat & Agar S. Citrate & - & + \\
\hline Katalase & NA Miring & - & - \\
\hline Urease & Kaldu Urea & - & - \\
\hline $\mathrm{H}_{2} \mathrm{~S}$ & Agar $\mathrm{H}_{2} \mathrm{~S}$ & + & + \\
\hline Metil Merah & Kaldu R-VP & + & + \\
\hline Voges Proskauer & & + & + \\
\hline Hidrolisa Gelatin & Nutrien Gelatin & + & - \\
\hline \multirow{2}{*}{ Kesimpulan nama bakteri : } & Isolat 1 & Bacillus & \\
\hline & Isolat 2 & Bacillus & \\
\hline
\end{tabular}

Analisis fenotip berdasarkan karakteristik isolat simbion Spons Callyspongia sp melalui uji biokimia yang dilakukan sebanyak 15 paramter standar uji biokimia. Tabel 4.2, memperlihatkan hasil uji sitrat terhadap isolat 1 , hasil reaksi negatif, menunjukkan pada isolat 1 tersebut terdapat sumber karbon lain selain karbon dari media sitrat, sedangkan pada isolat 2, hasil reaksi positif berarti isolat mampu menggunakan karbon pada media sitrat sebagai sumber karbon. Uji gelatin, terhadap isolat 1 , hasil reaksi positif berarti isolat mempunyai enzim gelatinase, 
sedangkan terhadap isolat 2 , hasil reaksi negatif, artinya isolat tidak memiliki enzim gelatinase.

Hasil uji urease, terhadap isolat 1 dan 2 menunjukkan hasil negatif, berarti kedua isolat tidak mampu menghidrolisis urea, artinya kedua isolat tersebut memiliki enzim urease, sedangkan pada uji Voges kedua isolat (isolat 1 dan 2) menunjukkan hasil reaksi positif, artinya terdapat mikroorganisme pada kedua isolat yang mampu melaksanakan fermentasi 2,3 butanadiol. Uji metil merah terhadap kedua isolat menunjukkan hasil reaksi positif, mengindikasikan bahwa kedua isolat dapat menghasilkan asam pada fermentasi glukosa.

Uji katalase terhadap isolat 1 dan 2, hasil reaksi negatif, artinya kedua isolat tidak memiliki enzim katalase yang dapat mendegradasi hidrogen peroksida $\left(\mathrm{H}_{2} \mathrm{O}_{2}\right)$, sedangkan pada uji fermentasi menggunakan pereaksi glukosa, laktosa, sukrosa terhadap kedua isolat, hasil reaksi negatif, kecuali pada uji menggunakan pereaksi mannitol dimana kedua isolat menunjukkan reaksi positif, berarti bakteri yang tumbuh dalam media cair hasil fermentasi berupa asam. Hasil karakterisasi melelui uji pewarnaan gram dan uji biokimia menunjukkan bahwa kedua isolat mikrosimbion Callyspongia sp mengandung enzim, memiliki kemampuan fermentasi dan kemampuan untuk mengolah karbon dari lingkungannya, sehingga diprediksi bahwa mikrosimbion spons Callyspongia sp tersebut mampu menggunakan komponen penyusun tubuhnya untuk mengurai komponen hidrokarbon menjadi komponen senyawa organik sederhana.

Hasil uji biokimia pada Tabel 2.3, berdasarkan uji TSIA (Triple Sugar Iron Agar) terhadap isolat A, B, dan C pada daerah slant warna media menjadi merah artinya isolat tersebut bersifat asam. Hal ini menandakan bahwa isolat ini mampu memfermentasi laktosa dan sukrosa. Pada daerah butt isolat A dan B bersifat basa menandakan isolat tersebut tidak dapat memfermentasi glukosa sedangkan pada isolat $\mathrm{C}$ media berubah menjadi kuning artinya besifat asam yang menandakan bahwa isolat tersebut mampu memfermentasi glukosa.Contoh lain terkait dengan analisis Fenotip melalui uji biokimia juga dapat dilihat pada Tabel 4.3, berikut: 
Tabel 4.3. Hasil karakterisasi isolat mikrosimbion spons Petrisia sp melalui uji

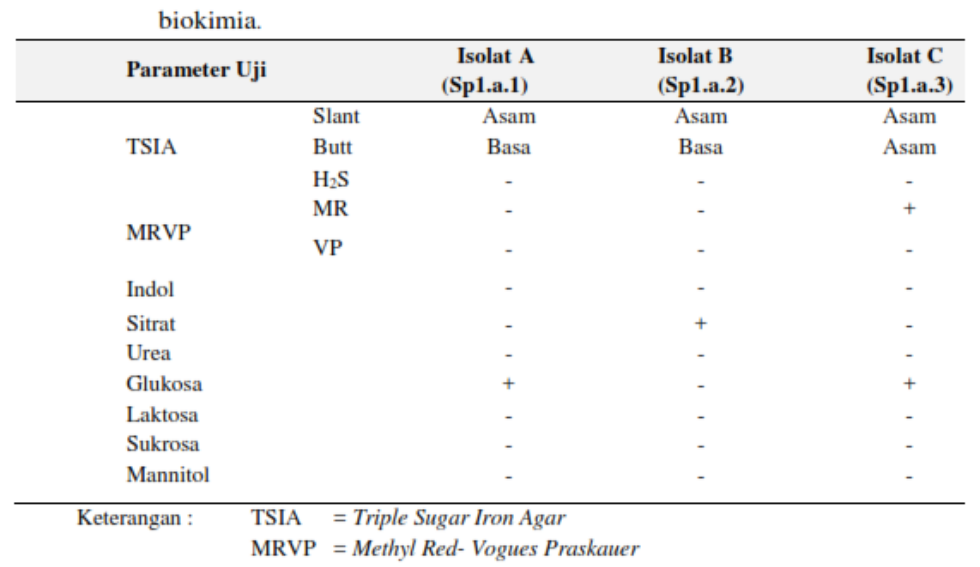

Pembentukan gas hasil dari fermentasi $\mathrm{H}_{2}$ dan $\mathrm{CO}_{2}$ dapat dilihat dari pecahnya agar. Pembentukan gas $\mathrm{H}_{2} \mathrm{~S}$ ditandai dengan adanya endapan warna hitam. Pada isolat $\mathrm{A}, \mathrm{B}$, dan $\mathrm{C}$ tidak terbentuk gas $\mathrm{H}_{2} \mathrm{~S}$ hal ini menandakan bahwa isolat tersebut tidak mampu memfermentasi asam amino metionin dan sestein. Jika isolat mampu memfermentasi kedua asam amino ini maka gugus $\mathrm{S}$ akan keluar dan bereaksi dengan $\mathrm{H}_{2} \mathrm{O}$ membentuk $\mathrm{H}_{2} \mathrm{~S}$, dimana $\mathrm{H}_{2} \mathrm{~S}$ akan bereaksi dengan $\mathrm{Fe}^{2+}$ yang terdapat pada media membentuk FeS berwarna hitam dan mengendap.

Pada uji MRVP (Methyl Red-Vogues Praskauer) untuk analisa MR isolat $\mathrm{C}$ menunjukkan hasil positif karena media berubah menjadi merah setelah ditambahkan metil red artinya isolat ini menghasilkan asam campuran (metilen glikon) dari proses fermentasi glukosa yang terkandung dalam media MR. Sedangkan isolat A dan B menunjukkan hasil negatif karena warna media mendekati merah. Untuk analisa VP ketiga isolat menunjukkan hasil negatif karena tidak terbentuk warna merah setelah ditambahkan $\alpha$ naphtol dan $\mathrm{KOH}$ artinya hasil akhir fermentasi isolat ini bukan asetil metil karbinol (asetoin).

Pada uji indol terhadap isolat $\mathrm{A}, \mathrm{B}$ dan $\mathrm{C}$ menunjukkan hasil negatif karena tidak terbentuk cincin berwarna merah muda, berarti ketiga isolat tersebut tidak memiliki indol dari tryptopan sebagai sumber karbon. Asam amino tryptopan merupakan komponen asam amino yang lazim terdapat pada protein sehingga asam amino ini dengan mudah dapat digunakan oleh mikroorganisme akibat penguraian protein.

Berdasarkan uji sitrat terhadap isolat $\mathrm{A}$ dan $\mathrm{C}$ hasil reaksinya negatif karena tidak terjadi perubahan warna pada media menununjukkan isolat tersebut tidak mempunyai enzim sitrat permease yaitu enzim spesifik yang membawa sitrat ke dalam sel. Sehingga isolat tersebut tidak menggunakan sitrat sebagai satu-satunya sumber karbon. Sedangkan 
isolat B hasil positif karena terjadi perubahan warna dari hijau ke biru, berarti isolat ini mampu menggunakan karbon pada media sitrat sebagai sumber karbon. Hasil reaksi pada uji urease terhadap isolat A, B dan C menunjukkan hasil negatif karena tidak terjadi perubahan warna pada media berarti isolat ini tidak mampu menghidrolisis urea, artinya ketiga isolat tersebut tidak memiliki enzim urease yang dapat menguraikan urea membentuk amoniak.

Hasil uji fermentasi menggunakan pereaksi glukosa, laktosa, sukrosa dan mannitol terhadap ketiga isolat memberikan hasil negatif karena tidak terjadi perubahan warna dari merah ke kuning hal ini menunjukkan bahwa media tidak dapat memfermentasi gula, sedangkan untuk uji glukosa isolat $\mathrm{A}$ dan $\mathrm{C}$ menunjukkan hasil positif karena terjadi perubahan warna dari merah ke kuning menunjukkan bahwa isolat tersebut memfermentasi gula membentuk asam. Dengan demikian dapat dikatakan bahwa penentuan perkiraan jenis isolat atau bakteri dapat diperkirakan minimal golongan dan isolat bakteri.

\section{3. Analisis Genotip Spons}

Genotip adalah pewarisan individu dengan tanpa ekspresi fenotip dari sutu atau beberapa sifat, dimana penentuan pewarisan individu ditentukan dari penampakan keturunan atau kerabatnya. Penentuan pewarisan individu tersebut dapat dilihat pada susunan genotip DNA, karena genotip merupakan kode genetik dalam sel individu, termasuk sel bakteri.

Polymerase Chain Reaction (PCR) adalah suatu metode in vitro untuk menghasilkan sejumlah fragmen DNA spesifik dengan panjang dan jumlah skuens yang telah ditentukan dari jumlah kecil template kompleks. Deocsiribosa Nukleat Acid (DNA) isolat murni diekstraksi dengan metode Chelex 20\%, lalu dilakukan PCR melalui 35 siklus, didenaturasi pada suhu $95{ }^{\circ} \mathrm{C}, 1$ menit, annealing pada suhu $55^{\circ} \mathrm{C}: 1$ menit dan extension pada suhu $72{ }^{\circ} \mathrm{C}$ : 2 menit, diinkubasi pada suhu $72{ }^{\circ} \mathrm{C}$ : 10 menit, (Alamri, 2010). DNA dielektro-foresis, produk PCR dengan pita yang jelas berukuran $150 \mathrm{bp}$.

Sekuensing dilakukan dengan mengirim DNA ke Macrogen, hasil sekuensing diidentifikasi ke GenBank melalui program BLAST (Basic Local Alignment Search Tool) atau pensejajaran berganda dengan GenBank dalam program BioEdit versi 7.2.5. Primer FP-U1 (5'CCAGCAGCCGCGGTAATA-CG-3').

Ciri fisik sampel spons yang teramati secara langsung dilapangan, warna krem kecoklatan, bentuk memanjang sebagian bergerombol, memiliki spikula berupa silikat dan sponging berserabut. pertumbuhan 
spons membentuk massiva dan oscula berserak sepanjang permukaan badan spons, keleton tidak beraturan dan berisi spongin terdiri atas bagian utama dan bagian berserabut. Berdasarkan hal tersebut maka disimpulkan bahwa spons teridentifikasi dengan spesies Callyspongia sp, family Callyspongiidae, kelas Demospongiae. Analisis genotip didasarkan pada susunan pasangan DNA, atau sequencing dari spesies isolat menggunakan primer spesifik.

Contoh hasil analisis genotip melalui karakterisasi molekul gen 16S rRNA mikrosimbion Callyspongia sp dapat dilakukan dengan mengidentifikasi urutan pasangan molekul gen DNA melalui metode Polimerase Chain Reaction (PRC). Hasil sekuensing molekul gen DNA yang diperoleh berupa data mentah dalam bentuk kromatogram, selanjutnya molekul gen tersebut diurutkan dan dibentangkan. Gambar 4.4, adalah hasil isolasi dan amplifikasi DNA isolat 1 dan 2.
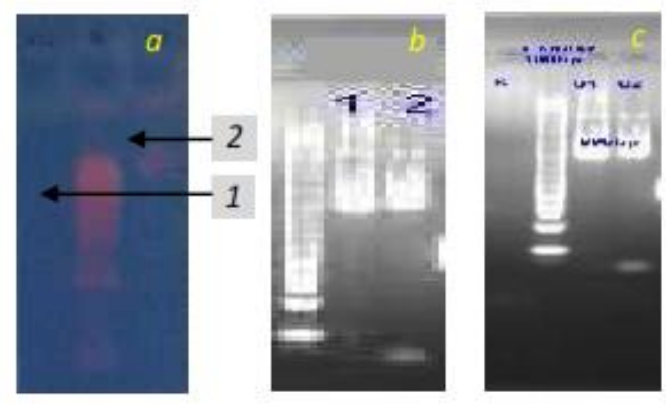

Gambar 4. 4. a) Hasil isolasi DNA Genom isolat mikrosimbion Spons Callyspongia sp, no.1 genom pembanding dan no. 2 genom sampel; b) hasil amplifikasi genom, no. 1 perkiraan base pair (bp) isolat 1 (Sp 1.b.1) dan no. 2 isolat 2 (Sp 1.b.2); c) hasil amplifikasi isolat 1 dan 2 setelah pemurnian dengan perkiraan $996 \mathrm{bp}$.

Kromatogram yang diperoleh diproses menggunakan perangkat software program BioEdit versi 7.2.5. Data yang telah diolah oleh program BioEdit digunakan sebagai data dasar untuk diolah kembali pada multiple alignment (pensejajaran berganda) urutan molekul gen isolat terhadap molekul DNA database yang ada pada GenBank, dimana molekul gen 16S rRNA bersifat universal pada bakteri, secara umum dapat diperbandingan dengan urutan RNA sampel. 
Hasil sekuensing isolat dibuka melalui program bioedit, kemudian sekuen DNA bakteri sampel dimasukkan ke program BLAST (Basic Local Alignment Search Tool), (http://blast.ncbi.nlm.nih.gov/Blast. cgi), sekuen diidentifikasi dengan database DNA GenBank pada situs tersebut. Hasil pensejajaran sekuen sampel dengan sekuen GenBank menunjukkan kesamaan deret homolog yang tinggi, dapat dilihat pada Tabel 4. 4, berikut:

Tabel 4. 4. Hasil BLAST (Basic Local Alignment Search Tool) isolat mikrosimbion spons Callyspongia sp

\begin{tabular}{|c|c|c|c|lll|}
\hline $\begin{array}{c}\text { Kode } \\
\text { Sampel }\end{array}$ & $\begin{array}{c}\text { Sekuen } \\
\text { Sampel }\end{array}$ & $\begin{array}{c}\text { Sekuen Gen- } \\
\text { Bank }\end{array}$ & Identitas (\%) & \multicolumn{2}{|c|}{ Spesies } \\
\hline $\begin{array}{c}\text { Isolat 1 } \\
\text { (Sp 1.b.1) }\end{array}$ & $17-916$ & $554-1461$ & $\begin{array}{c}817 / 913 \\
(89 \%)\end{array}$ & $\begin{array}{l}\text { Bacillus } \\
1684\end{array}$ & subtilis & strain BAB- \\
\hline $\begin{array}{c}\text { Isolat 2 } \\
\text { (Sp 1.b.2) }\end{array}$ & $10-960$ & $19-968$ & $\begin{array}{c}948 / 952 \\
(99 \%)\end{array}$ & $\begin{array}{l}\text { Bacillus } \\
\text { PHCDB20 }\end{array}$ & flexus & strain \\
\hline
\end{tabular}

Analisis urutan sekuen DNA sampel isolat 1 pada bentangan nukleotida 17-916 atau $899 \mathrm{bp}$, dengan rincian golongan purin terdiri atas 28,44\% Guanin; 24,27\% Adenin dan golongan pirimidin terdiri atas 25,10\% Citosin; 21,15\% Timin; dan terdapat 1,04\% deretan non pasangan nukleotida. Isolat tersebut memiliki kesamaan genus yang tinggi mencapai $89 \%$ homolog terhadap pensejajaran berganda sekuen GenBank pada bentangan 554-1461 bp, Selanjutnya spesies isolat 1 teridentifikasi jenis Bacillus subtilis strain BAB-1684.

Urutan sekuen DNA isolat 2 pada bentangan nukleotida 10-960 atau $950 \mathrm{bp}$, dengan rincian golongan purin, terdiri atas 30,62\% Guanin; 25,46 $\%$ Adenin; dan golongan pirimidin terdiri atas 22,58 \% Citosin; 20,31\% Timin; dan terdapat 1,03\% deretan non pasangan nukleotida, (Marzuki et al., 2015). Isolat 2 tersebut memiliki kesamaan genus yang tinggi mencapai $99 \%$ homolog terhadap pensejajaran berganda sekuen GenBank pada bentangan 19-968 bp yang teridentifikasi Bacillus flexus strain PHCDB20. Spesies Bacillus subtilis dan Bacillus fexus, keduanya merupakan genus Bacillus, family Bacillaceae dan kelas Bacilli. Penelitian sebelumnya telah dilakukan identifikasi Basillus Subtilis strain berbeda terhadap isolat hasil isolasi mangrove dengan metode PCR pada \pm 800 bp, dan identifikasi Basillus flexus strain SSZ10 isolat hasil isolasi bakteri sedimen Laut Merah dengan metode PCR pada \pm 1.000 bp. 
Hasil BLAST mencapai tingkat kesamaan genus tinggi apabila mencapai di atas $80 \%$ homolog. Identifikasi melalui PCR dan sekuensing DNA bakteri melalui program BLAST lebih menyakinkan karena dibandingkan dengan data DNA bakteri pada GenBank yang memuat puluhan hingga jutaan data DNA bakteri yang ada. Analisis genotip melalui metode PCR dengan pengurutan gen 16S rRNA memungkinkan identifikasi bakteri lebih akurat daripada yang diperoleh dengan pengujian fenotip. Analisis 16S rRNA memungkinkan penemuan bakteri patogen baru, karena dapat mengidentifikasi bakteri yang tidak dapat dikultur. Berdasarkan hasil uji biokimia dengan memperhatikan hasil reaksi setiap media uji dikombinasikan dengan hasil identifikasi molekul gen $16 \mathrm{~S}$ rRNA metode PCR memberi petunjuk bahwa kedua spesies, (Bacillus subtilis strain BAB-1684 dan Bacillus flexus strain PHCDB20) dapat melaksanakan reaksi kimia pemecahan molekul hidrokarbon, sehingga dapat diduga bahwa spons Callyspongia sp dapat hidup dan mampu menyesuaikan diri dengan lingkungan ekstrim tercemar hidrokarbon seperti pada Pantai Melawai Balikpapan Kalimantan Timur. Untuk memastikan kemampuan degradasi mikrosimbion dan biomassa spons Callyspongia sp, maka dilakukan uji pertumbuhan suspensi mikrosimbion/SBS pada media limbah SMB. Karakterisasi molekul gen 16S rRNA bakteri dilakukan dengan mengidentifikasi urutan pasangan molekul gen DNA melalui metode Polimerase Chain Reaction (PCR). Hasil amplifikasi DNA isolat bakteri ditunjukkan 4. 5, berikut:

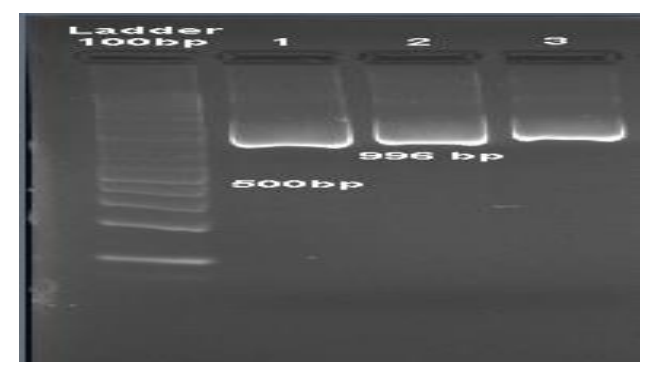

Gambar 4.5. a) Hasil isolasi DNA Genom (amplifikasi) isolat mikrosimbion spons Petrosia sp. No. 1 adalah genom pembangding dan No. 2 genom sampel. b) merupakan hasil amplifikasi genom 1, diperkirakan base pair (bp) isolat $\mathrm{A}$ (Sp1.a.1); Isolat B (Sp1.a.2) dan isolat C (Sp1.a.3). Hasil amplifkasi isolat 1 dan 2 setelah pemurnian dengan perkiraan 996 bp. 
Hasil sekuensing molekul gen DNA diolah dengan menggunakan perangkat software Bioedit versi 7.2.5, sehingga diperoleh urutan molekul gen isolat terhadap molekul DNA database yang ada pada GenBank, dimana molekul gen 16S rRNA bersifat universal pada bakteri, secara umum dapat dibandingkan dengan urutan RNA sampel. Sekuen DNA gen 16S rRNA ini dianalisis dengan program BLAST (Basic Local Alignment Search Tool) dari NCBI (National Center for Biotechnology Information). Hasil pensejajaran sekuen sampel dengan sekuen GenBank menunjukkan kesamaan deret homolog yang tinggi, yang ditunjukkan pada Tabel 4.5, berikut:

Table 4. 5. Hasil BLAST (Basic Local Alignment Search Tool) bakteri

\begin{tabular}{ccccl}
\hline Sampel & $\begin{array}{c}\text { Sekuen } \\
\text { Sampel }\end{array}$ & $\begin{array}{c}\text { Sekuen } \\
\text { GenBank }\end{array}$ & Identitas (\%) & \multicolumn{1}{c}{ Spesies } \\
\hline Isolat A (Sp1.a.1) & $6-933$ & $18-945$ & $918 / 928(99 \%)$ & Alcaligenes faecalis \\
Isolat B (Sp1.a.1) & $6-939$ & $541-1477$ & $926 / 927(99 \%)$ & Sphingobacterium sp. \\
Isolat C (Sp1.a.1) & $1-894$ & $512-1408$ & $891 / 898(99 \%)$ & Bacillus cereus \\
\hline
\end{tabular}

Analisis urutan sekuen DNA sampel isolat A, B dan C memiliki kesamaan genus yang tinggi yaitu 99\% dimana isolat tersebut teridentifikasi jenis Alcaligenes faecalis, Sphingobacterium sp. dan Bacillus cereus. Hasil BLAST yang mencapai tingkat kesamaan genus tinggi apabila mencapai diatas $80 \%$ homolog. Identifikasi melalui PCR dan sekuensing DNA bakteri melalui program BLAST lebih meyakinkan karena dibandingkan dengan data DNA bakteri pada GenBank yang memuat puluhan hingga jutaan data DNA bakteri yang ada. Analisis $16 \mathrm{~S}$ rRNA memungkinkan penemuan bakteri patogen baru, karena dapat mengidentifikasi bakteri yang tidak dapat dikultur.

Ada empat tahap isolasi DNA, yakni pemecahan sel, ekstraksi DNA, presipitasi DNA dan pencucian DNA. Metode PCR dengan pengurutan gen 16S rRNA memungkinkan identifikasi bakteri lebih akurat daripada yang diperoleh dengan pengujian fenotip. Analisis 16S rRNA memungkinkan penemuan patogen baru, karena dapat mengidentifikasi bakteri yang tidak dapat dikultur.

Hasil sekuensing yang diperoleh berupa data mentah, selanjutnya diolah menggunakan perangkat software program BioEdit versi 7.2.5. Data yang telah diolah oleh program BioEdit digunakan sebagai data dasar untuk diolah kembali pada multiple alignment (pensejajaran berganda) 
dengan database. Gen 16S rRNA bersifat universal pada bakteri, secara umum perbandingan urutan 16S rRNA. Hasil sekuensing dibuka melalui program bioedit, kemudian sekuen DNA bakteri dimasukkan ke program Basic Local Alignment Search Tool, (http://blast.ncbi. nlm.nih.gov/Blast. cgi), sekuen diidentifikasikan dengan database DNA GenBank pada situs tersebut.
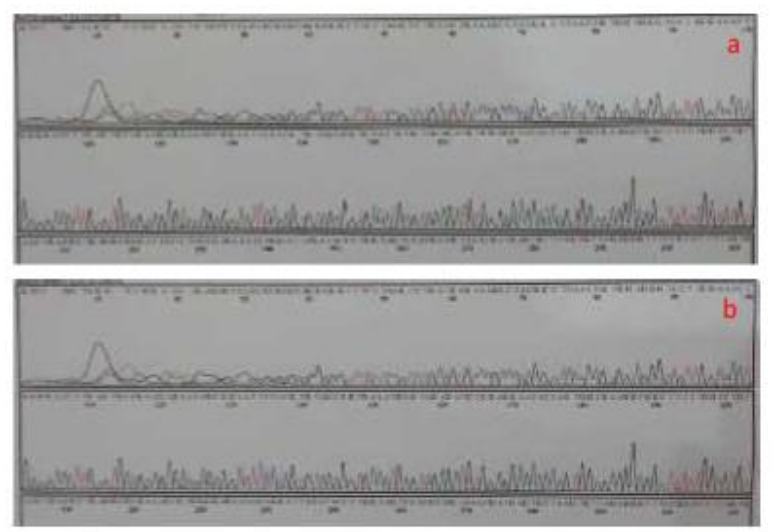

Gambar 4. 6. Kromatogram potongan sekuen DNA isolat bakteri simbion Callyspongia sp, a) isolat 1 (Sp 1.b.1) potongan sekuen 17-230 bp, b) Isolat 2 (Sp 1.b.2) potongan sekuen 10-205 bp

Hasil BLAST yang mencapai tingkat kesamaan genus tinggi apabila mencapai di atas $80 \%$ homolog Identifikasi melalui PCR dan sekuensing DNA bakteri melalui program BLAST lebih menyakinkan karena dibandingkan dengan data DNA bakteri pada GenBank yang memuat puluhan hingga jutaan data DNA bakteri yang ada, (Samaila et al. 2014). Hasil ini memberi keyakinan yang kuat bahwa kedua spesies ini merupakan genus Bacillus, diketahui dapat melaksanakan reaksi kimia pemecahan molekul hidrokarbon, sehingga wajar apabila spons Callyspongia sp yang bersimbion dengan Basillus subtilis dan Basillus flexus dapat hidup dan mampu menyesuaikan diri dengan lingkungan tercemar hidrokarbon seperti pada Pantai Melawai Balikpapan Kalimantan Timur.

Kesimpulan yang dapat disusun sebagai hasil dari analisis genotip dalam metode PCR tentang karakterisasi molekul gen 16S rRNA mikro simbion spons asal area tercemar limbah hidrokarbon pada Pantai Melawai Balikpapan Kalimantan Timur dan juga pada Pulau Kodingareng Keke, Kepulauan Spermode adalah pada analisis histomorfologi diperoleh 
spons dengan spesies Callyspongia sp. Hasil isolasi dan purifikasi mikro simbion spons diperoleh 2 (dua) isolat. Karakteristik Isolat 1, berbentuk bulat, berkoloni dan berwarna krem, sedangkan isolat 2, bentuk bergerigi, lonjong berkoloni dan berwarna putih. Sedangkan hasil karakterisasi molekul gen 16S rRNA dengan metode PCR menggunakan primer FP-U1 (5'-CCAGCAGCCGCGGTAATA-CG-3') pada nukleotida 518-537, dan RP-U2 (5'-ATCGG (C/T) TACCTTGTTACG-ACTTC-3'), untuk isolat 1 adalah bakteri spesies bacillus subtilis strain BAB-684 dengan jumlah pasangan nukleotida mencapai 899 bp dan tingkat kesamaan pada genbank mencapai $89 \%$ homolog, sedangkan isolat 2 adalah spesies bacillus flexus strain PHCDB20 dengan jumlah pasangan nukleotida mencapai 950 bp dengan tingkat kesamaan pada genbank mencapai $99 \%$ homolog. Kedua spesies yang merupakan mikro simbion spons Callyspongia sp diperoleh dari lingkungan tercemar hidrokarbon menunjukkan bahwa spons dan mikro simbionnya mampu hidup dan dapat mendegradasi limbah hidrokarbon. 


\section{Bab -5-}

\section{KARAKTERISTIK LINGKUNGAN, EKSTRAKSI DAN DAYA HAMBAT MIKROSIMBION}

\subsection{Karakteristik Lingkungan Habitat Spons}

Spons yang hidup pada suatu area dipengaruhi oleh kondisi lingkungan tempat hidup spons. Lingkungan yang memiliki nutrisi yang cukup untuk kehidupan spons berpengaruh pada jenis dan jumlah mikrosimbion spons. Ketersediaan nutrisi, tofograpi, $\mathrm{pH}$, temperatur, kedalaman area, arus bawah laut dan kekeruhan, ada tidak cemaran, jenis cemaran (plastik, logam berat, hidrokarbon atau gabungan antara dua dan tiga jenis cemaran) adalah faktor-faktor yang memberi pengaruh pada pertumbuhan dan perkembangan spons, termasuk pada jenis spons yang dapat dihup pada area tersebut dan juga jenis dan jumlah sombiosisi yang mungkin terjadi tanpa kecuali pada pembentukan zat aktif spons dan kemampuan spons dalam menjalankan aktivitas sebagai anti bakteri, anti fungi yang memiliki daya hambat dengan besaran nilai daya hambat dapat bervariasi sesuai dengan ferforma ekstrak mikrosimbion terhadap bakreri uji.

Tofografi habitat yang landai, memberi kenyamanan dan ketenangan serta keuntungan bagi spons untuk beradaptasi dan dapat melakukan nutrisi yang baik sehingga pertummbuhan dan perkembangan spons cenderung lebih baik. Kekuatan asam-basa air laut dimana spons tersebut hidup, memberi pengaruh pada jenis spons yang dapat hidup karena kemampuan adaptasi. Kedalaman lokasi dimana komunitas spons tersebut berada berpengaruh signifikan terhadap jenis spons yang dapat hidup pada area tersebut. Arus bawah laut yang juga identik dengan ketenangan spons termasuk kemungkinan terjadinya kekeruhan akan sangat berpengaruh nyata pada proses dan mekanisme adaptasi spons yang pada akhirnya akan berdampak pada jenis spon yang dapat hidup pada area tersebut, termasuk pada proses pertumbuhan, apakah maksimal dan efektif atau tidak. Adanya pencemaran dan jenis penjemaran yang terjadi termasuk waktu paparan apakah lama atau berlangsung pada waktu relatif singkat berpengaruh signifikan pada pertumbuhan spons bukan hanya 
pada jenis spons yang dapat dihup tetapi berdampak pada pertumbuhan dan perkembangan spons yang lambat bahkan spons dapat saja mati.

Gambaran lingkungan lokasi pengambilan sampel spons sekitar Pulau Kodingareng Keke Wil. Kecamatan Ujung Tanah, Kota Makassar, yang diamati, disajikan dalam tabel 5.1., berikut:

Tabel 5. 1. Keadaan Lingkungan Lokasi Sampling Spons Pulau Kodingareng dan sekitarnya Sumber:

\begin{tabular}{|c|c|c|c|c|c|}
\hline Kode sampel & Suhu & Koordinat Sampling & $\mathrm{pH}$ & Salinitas & Kedalam (m) \\
\hline \multicolumn{6}{|c|}{ A. Spons yang diperoleh dari Pulau Kodingareng Keke, Kepulauan Spermonde, Sulawesi Selatan } \\
\hline $\begin{array}{c}\text { Sp. 1.a Petrosia } \\
\text { (Strongylophora) corticata }\end{array}$ & $29^{\circ} \mathrm{C}$ & $\begin{array}{c}05^{\circ} 06^{\prime} 06.76^{\prime \prime} \mathrm{LS} \\
119^{\circ} 17,10.66^{\prime \prime} \mathrm{BT}\end{array}$ & 7 & $29,3 \%$ & $\pm 3,2 \mathrm{~m} \mathrm{dpl}$ \\
\hline Sp. 2.a Niphates sp & $29^{\circ} \mathrm{C}$ & $\begin{array}{l}05^{0} 06^{\prime} 06.54^{\prime \prime} \mathrm{LS} \\
119^{\circ} 17^{\prime} 10.62^{\prime \prime B T}\end{array}$ & 7 & $29,3 \%$ & $\pm 3,2 \mathrm{~m} \mathrm{dpl}$ \\
\hline Sp. 3.a Hyrtios erectus & $29^{\circ} \mathrm{C}$ & $\begin{array}{l}05^{\circ} 06^{\prime} 06.81^{\prime \prime L S} \\
119^{\circ} 17,10.72^{\prime \prime B T}\end{array}$ & 7 & $29,3 \%$ & $\pm 3,2 \mathrm{~m} \mathrm{dpl}$ \\
\hline $\begin{array}{c}\text { Sp. } 4 . \mathrm{a} \\
\text { Clathria (Thalysias) reinwardti }\end{array}$ & $29^{\circ} \mathrm{C}$ & $\begin{array}{l}05^{\circ} 06^{\prime} 06.73^{\prime \prime L S} \\
119^{0} 17^{\prime} 10.62 " \mathrm{BT}\end{array}$ & 7 & $29,3 \%$ & $\pm 3,2 \mathrm{~m} \mathrm{dpl}$ \\
\hline \multicolumn{6}{|c|}{ B. Spons yang diperoleh dari Pantai Melawai Balikpapan, Kalimantan Timur } \\
\hline Sp 1.b Callyspongia sp & $29^{\circ} \mathrm{C}$ & $\begin{array}{c}01^{0} 16.31 \text { '7" LS } \\
116^{0} 48.26^{\prime} 4 \text { " BT }\end{array}$ & 7 & $29,5 \%$ & $\pm 2,7 \mathrm{~m} \mathrm{dpl}$ \\
\hline Sp 2.b Chalinidae & $29^{\circ} \mathrm{C}$ & $\begin{array}{l}01^{0} 16.34^{\prime} 0^{\prime \prime} \text { LS } \\
116^{0} 48.24^{\prime} 3^{\prime \prime} \text { BT }\end{array}$ & 7 & $29,3 \%$ & $\pm 3,0 \mathrm{~m} \mathrm{dpl}$ \\
\hline $\begin{array}{l}\text { Sp 3.b Callyspongia } \\
\text { (Cladocalina) vaginalis }\end{array}$ & $30^{\circ} \mathrm{C}$ & $\begin{array}{c}01^{0} 16.36^{\prime} 8^{\prime \prime} \text { LS } \\
116^{0} 48.23^{\prime} 6^{\prime \prime} \text { BT }\end{array}$ & 7 & $30,0 \%$ & $\pm 2,5 \mathrm{~m} \mathrm{dpl}$ \\
\hline Sp 4.b Chalinidae & $28^{\circ} \mathrm{C}$ & $\begin{array}{l}01^{\circ} 16.47 \text { ' } 1 " \text { LS } \\
116^{\circ} 48.34 \text { '2" BT }\end{array}$ & 7 & $29,5 \%$ & $\pm 3,2 \mathrm{~m} \mathrm{dpl}$ \\
\hline
\end{tabular}

Mencermati Tabel 5. 1, di atas menunjukkan bahwa terjadi variasi jenis spons yang dapat ditemukan pada area dengan kondisi lingkungan yang relatif sama, seperti $\mathrm{pH}$, keladaman, titik koordinat, dan temperatur, mengindikasikan bahwa jenis-jenis spons tersebut dapat bertahan pada keadaan lingkungan tertentu, akan tetapi jenis dan jumlah mikrosimbion yang dapat berasosiasi dengan spons-spons tersebut berpotensi lebih bervariatif ataupun mungkin saja jenisnya sama. Hal ini dapat terjadi karena faktor yang berpengaruh terhadap jenis spons, jumlah dan jenis mikrosimbion bukan hanya pada faktor sebagaimana tersebut di atas, tetapi faktor lainnya seperti nutrisi, predator terhadap spons, kekeruhan, arus bawah laut, pencemaran justru dominan memberi pengaruh pada jenis spons dan mikrosimbion yang dapat terjadi antara keduanya.

Efek lain yang mungkin timbul dari keadaan ini adalah jenis zat aktif yang dapat diproduksi oleh spons tersebut, termasuk pada karakter dan mekanisme kerja enzim yang dapat dihasilkan. Jumlah sampel spons yang diperoleh dari Pulau Kodingareng Keke, Gugusan Kepulauan Spermonde sebanyak 8 jenis. Setiap sampel spons selanjutnya dilakukan analisis morfologi untuk menentukan spesies setiap jenis, diperoleh hasil 
analisis morfologi. Hasil analisis terhadap data morfologi spons menunjukkan bahwa sedikitnya ada 5 jenis spons yang diduga bersimbions dengan jenis bakteri tertentu yang berpotensi dapat mendegradasi PAH. Karakteristik morfologi spons yang dimaksud dengan ciri-ciri spons tersebut dalam tubuhnya terdapat lendir atau tubuhnya diselimuti oleh lumpur sejenis lendir, dimana lendir/lumpur tersebut diproduksi dari zat berkarakter enzim yang ada dalam tubuh spons.

\section{2. Terumbu Karang dan Keberadaan Spons}

\section{2. 1. Definisi Karang dan Tutupan Karang}

Definisi terumbu karang sebagai ekosistem tersebut tidak netral karena tidak dapat digunakan oleh peneliti geologi. Bagi peneliti geologi terumbu karang adalah batuan sediment kalsium karbonat di dalam laut. Karena itu dibuatlah sebuah definisi terumbu karang yang netral. Terumbu karang didefinisikan sebagai batuan sediment kapur di dasar laut yang terbentuk dari proses biogenik. Berdasarkan definisi ini terumbu karang secara fisik berupa bukit berkapur di dalam laut dan benda-benda berkapur yang melekat di bukit tersebut. Benda berkapur semacam itu terdiri atas kerangka karang mati dan kerangka karang yang masih hidup, sedimensedimen berkapur yang tersebar di dasar terumbu. Terumbu karang, kadang disebut singkat saja sebagai terumbu. Kadang-kadang ada penulis menyingkat sebutan terumbu karang (coral reef) menjadi hanya terumbu (reef) saja, tetapi menjadi sebuah kesalahan jika memperpendek dengan sebutan dengan karang (coral) saja. Kejadian tersebut sering membingungkan orang yang baru memahami istilah terumbu karang. Ikan-ikan yang hidup di terumbu karang disebut ikan-ikan terumbu karang (coral reef fishes) atau ikan-ikan terumbu (reeffishes). Penggunaan istilah ikan-ikan karang tidak dikenal di dalam publikasi.

Pada Tabel 5. 2, di bawah terlihat bahwa pengamatan terhadap kondisi terumbu karang dilakukan pada empat stasiun dengan berbagai variasi kedalaman. Nilai prosentase tutupan karang hidup berkisar 14,61\% - 47,34\%. Prosentase tutupan karang hidup terbesar terjadi pada stasiun I pada kedalaman 5 meter, sedangkan prosentase tutupan karang terkecil didapatkan pada stasiun II pada kedalaman 6 meter. 
Tabel 5. 2. Prosentase Terumbu Karang Pada Perairan Pulau Kapoposang

\begin{tabular}{|c|c|c|c|c|c|c|c|}
\hline \multirow{2}{*}{ Stasiun } & \multirow{2}{*}{ Kedalaman (m) } & \multicolumn{4}{|l|}{ Benthic lifeform (\%) } & \multirow{2}{*}{ Kondisi } \\
\cline { 3 - 8 } & & HCL & DCA & Alga & OT & Abiotik & \\
\hline I & 5 & 47.34 & 0 & 0 & 7.60 & 42.90 & Sedang \\
\cline { 2 - 8 } & 15 & 24.24 & 0 & 0 & 12.48 & 54.90 & Rusak \\
\hline II & 6 & 14.61 & 39.96 & 0 & 40.43 & 5.00 & Rusak \\
\cline { 2 - 8 } & 15 & 28.40 & 2.40 & 0.52 & 18.78 & 49.90 & Sedang \\
\hline III & 5 & 42.32 & 6.24 & 4.55 & 10.75 & 36.14 & Sedang \\
\hline IV & 5 & 22.84 & 0 & 7.36 & 19.28 & 50.52 & Rusak \\
\hline
\end{tabular}

Pada Stasiun I dengan dua variasi kedalaman terlihat bahwa, kisaran prosentase tutupan karang pada HCL dan abiotik lebih besar dari komponen lainnya. Kondisi ini dapat dikatakan bahwa kondisi terumbu karang HCL pada stasiun ini berada dalam kategori sedang dan menjadi tempat tumbuh yang baik bagi sponge.

Pada Stasiun II dengan kedalaman 6 meter terlihat bahwa prosentase tutupan karang pada DCA dan OT lebih besar dari HCL dan Abiotik. Kondisi ini dapat dikatakan bahwa terumbu karang berada dalam kategori terumbu karang dalam kondisi yang rusak. Disamping itu, kondisi ini juga sangat baik bagi sponge untuk hidup dengan cara melekat pada pecahan karang, karang mati dan pada substrat berpasir. Hal ini didasari oleh sifat sponge yang memiliki kemampuan bersaing dengan organisme lain dalam mendapatkan tempat untuk tumbuh dan suplai nutrien, atau dengan kata lain sponge merupakan hewan pionir yang mampu beradaptasi terhadap lingkungan yang mengalami kerusakan.

Pada stasiun III terlihat bahwa prosentase tutupan karang pada HCL dan abiotik lebih besar dari komponen lainnya, sehingga kondisi terumbu karang pada stasiun ini dapat dikatakan berada dalam kategori sedang dan baik untuk pertumbuhan sponge. Pada Stasiun IV terlihat bahwa prosentase tutupan karang abiotik lebih besar dari komponen lainnya. Kondisi terumbu karang pada stasiun ini berada dalam kategori rusak. Kelangsungan hidup sponge pada stasiun ini didukung oleh besarnya prosentase tutupan karang pada komponen abiotik.

Sponge yang dijadikan contoh dan diangkap sebagai bagian dari isi tulisan ini sebanyak sembilan jenis yang dominan didapatkan pada keempat stasiun pengamatan. Kemudian sampel spons dibandingkan Karakteristik Lingkungan, Ekstraksi dan Daya Hambat Mikrosimbion [84] 
berdasarkan genus dan kondisi habitatnya. Keberadaan Sampel sponge dominan pada setiap stasiun pengamatan dapat kita lihat pada Tabel 5. 3, di atas.

Ekosisitem terumbu karang, dimana karang merupakan komponen yang utama, sehingga baik buruknya kondisi suatu terumbu karang ditentukan oleh banyak sedikitnya kelimpahan karang. Jika dianalogkan dengan ekosistem hutan, karang berperan sebagai pohon-pohon yang tumbuh dibukit terumbu. Disamping sebagai tempat tinggal, tempat makan dan berlindung dari banyak hewan lain, karang juga berfungsi sebagai pencegah terjadinya erosi. Jika pohon menahan erosi dengan banyak menyerap air dan memperkuat ketahanan tanaah, maka karang meencegah erosi dengan banyak menimbun sedimen kapur yang meleekat di terumbu.

\section{2. 2. Karang Lunak vs Karang Batu}

Di dalam banyak publikasi tentang terumbu karang sering beberapa istilah lainnya, yaitu : karang batu dan karang lunak, karang hematipik dan karang ahermatipik. Karang batu dan karang lunak merupakan kelompok hewan yang berbeda dalam subklas. Karang batu termasuk dalam subklas Zoanthatiria, sedangkan karang lunak dalam subklas Octocoralia. Secara fisik antara karang batu dan karang lunak mudah dibedakan di dalam air. Karang batu keras karena mempunyai kerangka berkapur, sedangkan karang lunak tidak mempunyai kerangka sehingga tubuhnya bergerakgerak oleh arus dan gelombang air. Karang batu (ordo Scleractinia) terpisah dari karang lunak (ordo Acyonacea) pada tingkat subklas. Karang batu termasuk dalam dari subklas Zoantharia. Karang lunak termasuk dalam subklas Octocoralia.

Pembahasan tentang 'karang', dimaksudkan adalah karang batu dari ordo Scleractinia, bukan 'karang lunak', bukan pula 'terumbu karang'. Jika pembahasan tentang karang lunak, tidak pernah menggunakan kata 'karang' saja, melainkan 'karang lunak'. Karang lunak berada dalam satu subklas dengan karang ahermatipik, yaitu karang batu yang tidak mengandung zooxanthellae di dalam jaringan tubuhnya. Kelompok karang lunak ini adalah karang biru dan karang merah, sedangkan karang batu yang masuk dalam ordo Scleractinia semuanya merupakan karang yang hermatipik. Adanya algae zooxanthellae membuat karang batu 
mendapatkan energi ekstra dari sumbangan alga sehingga umumnya tumbuh lebih cepat. Istilah karang jika digunakan secara tersendiri, biasanya mengacu pada istilah karang batu, atau karang yang menghasilkan kapur.

Sebagai suatu hewan karang memiliki sifat-sifat yang sangat istimewa. Banyak karakteristik karang yang tidak banyak dimiliki oleh hewan darat pada umumnya. Sebagian tubuhnya besar, karang merupakan hewan sesil yang tumbuh di substrat berkapur yang keras, yaitu terumbu. Mirip dengan layaknya tanaman yang tumbuh di suatu bukit. Karang mengandalkan fotosintesis dari algae di dalam jaringannya untuk tumbuh, sehingga karang selalu membutuhkan cahaya matahari yang terang sebagaimana tumbuhan. Proses reproduksi dan penyebaran larva karang, mirip tumbuhan daripada hewan.

\section{2. 3. Karang Batu dan Invertebrata Kerabatnya}

Invertebrata yang tergabung dalam kelas Anthozoa di bagi menjadi dua, yaitu Subklas Octocoralia yang mempunyai 8 tentakel dan 8 mesenteri, dan Subklas Zoantharia yang mempunyai tentakel dan mesenteri lebih dari 8. Pembagian subklas Octocoralia menjadi 6 ordo, demikian juga Subklas Zoantharia terbagi dalam 6 ordo. Keenam ordo dalam subklas Octocoralia adalah Stolonifera, Telestacea, Alcyonacea, Gorgonacea dan Pennatulacea.

Di antara keenam ordo tersebut, jenis-jenis yang perlu diperhatikan di terumbu karang adalah karang merah atau karang pipa organ Tubipora, Clavularia (ordo Stolonifera); karang lunak Alcyonium, Sarcophyton, Lobophyton, dan Xenia (ordo Alcyonacea); karang biru Heliopora (ordo Helioporacea); karang gorgonia Gorgonia, Leptogorgia, Muricea (orgo Gorgonacea); serta pena laut Stylatula, Veretillum, dan Renila. Subklas Zoantharia terdiriatas ordo Zoanthidea, Actiniaria, Scleractinia (Madreporaria), Corallimorpharia, Ceriantharia dan Antipatharia. Ordo Scleractinia meliputi semua jenis karang batu (hermatipik) misalnya Acropora, Fungia, Goniastrea, Montipora, Pocillopora, Porites. Ordo Actinaria meliputi kelompok anemon laut seeperti Metridium, Stichodactyla, Epiactis. Ordo Zoanthidae meliputri bermacam-macam hewan zoantid yang kurang dikenal orang, misalnya zoanthus, Palythoa, Epizoanthus. 
Sistem klasifikasi tersebut, kelompok anemon dan zoanthid merupakan kerabat terdekat dari karang batu. Karang lunak, karang biru dan karang merah merupakan kelompok yang kekerabatannya lebih jauh karena berbeda subklas. Karang api Millepora (Ordo Milleporina) mempunyai kekerabatan yang paling jauh dengan karang batu. Karang api termasuk dalam Klas Hydrozoa (Filum Cnidaria), yang mempunyai fase medusa dalam siklus hidupnya. Karang merah, karang biru dan karang api biasanya dikelompokkan tersendiri sebagai karang non-scleractinia.

\section{2. 4. Terumbu Karang}

Terumbu karang merupakan struktur fisik dari kalsium karbonat (berbahan kapur) di dalam laut yang berasal dari sedimentasi proses biogenik. Berdasarkan lokasi dan topografi terumbu karang dibagi menjadi bermacam-macam tipe. Banyak ilmuwan menggunakan klasifikasi yang berbeda-beda, maka beberapa macam tipe seringkali saling tumpang tindih atau identik dengan lainnya. Di sini hanya empat tipe terumbu karang yang dibahas untuk menyederhanakan istilah-istilah penting.

Terumbu tepi (fringing reef). Terumbu tepi biasanya dianggap sebagai terumbu sederhana ynag tumbuh di tepi pulau. Terumbu tepi merupakan tipe terumbu karang yang paling banyak dijumpai di Indonesia, dan merupakan terumbu karang yang banyak dikunjungi wisatawan seperti di Bali, Lombok, Manado dan Banda.

Terumbu penghalang (barrier reef). Terumbu tipe ini tumbuh membatasi pulau dari lautan lepas. Contoh terumbu ini terdapat di selatan Pulau Buru dan selatan Teluk Tomini. Terumbu penghalang yang paling besar tumbuh di the Great Barrier Reefs, Australia, yang tumbuh di sepanjang landas kontinen pantai timur laut Queensland. Terumbu penghalang Sunda Besar (Great Sunda Barrier Reefs) tumbuh melindungi pantai tumur Kalimantan, dan merupakan yang terbesar di Indonesia. Terumbu penghalang yang besar biasanya terdiri atas banyak terumbuterumbu kecil yang tidak bisa dibedakan dengan terumbu tepi.

Atol adalah salah satu jenis terumbu karang. Tipe atol biasanya berbentuk cincin atau tapal kuda jika dilihat dari atas. Atol bisa terjadi karena menurunnya permukaan batuan atau menaiknya permukaan air laut. Di tengah atol terdapat goba. Atol terbesar di Indonesia adalah Atol 
Taka Bonerate, Laut Flores. Di Kepulauan Tukang Besi, Laut Banda, banyak ditemukan atol-atol yang kecil, misalnya Atol Lintea, Atol Kaledupa, Atol Kapota, Atol Koka dan Atol Noname. Atol juga disebut sebagai pulau tinggi karena terumbu ini dikelilingi oleh laut yang dalam. Taket dan gosong (shoal and coral cay). Taket dan gosong merupakan pulau yang rendah dan tersusun seluruhnya oleh sedimen biogenik (zat kapur dari karang dan biota lainnya). Istilah taket biasaanya digunakan untuk pulau yang hanya muncul ketika air laut sedang surut saja. Sedangkan istilah gosong biasanya digunakan untuk pulau pasir baik yang belum bervegetasi maupun yang sudah bervegetasi. Pulau rendah tipe taket dan gosong merupakan jenis pulau yang terbanyak jumlahnya di Indonesia.

Berdasarkan tipe komunitas dan topografi fisiknya suatu terumbu dibagi menjadi beberapa habitat, yaitu rataan terumbu (reef flat), gudus (reef crest), tubir (reef slope) dan goba (lagoon). Rataan terumbu merupakan bagian terumbu yang dangkal dan biasanya mempunyai topografi yang relatif rata. Pada terumbu tepi, rataan terumbu merupakan bagian dimana biasanya masyarakat mencari siput ketika air surut. Gudus merupakan ujung rataan terumbu yang tumbuh naik sebelum turun ke tubir. Gudus merupakan tempat terjadinya pemecahan ombak ketika pasang naik, dan terdedah ke udara ketika surut. Tubir merupakan bagian terumbu yang menurun ke bawah. Keterjalan tubir bervariasi dari sekitar $40-90^{\circ}$. Lagoon merupakan kolam yang dalam dan terlindung dari arus dan gelombang oleh rataan terumbu

Hingga saat ini, banyak peneliti dan akademisi di Indonesia yang menggunakan istilah karang dan terumbu karang secara salah. Dibandingkan dengan negara-negara ASEAN lainnya, memang negara Indonesia termasuk yang ketinggalan dalam penelitian dan publikasi tentang karang dan terumbu karang. Satu-satunya buku tentang karang di Indonesia yang sudah lama terbit adalah Coral of Batavia yang diterbitkan pada jaman Belanda. Sedangkan di negara ASEAN lainnya, misalnya Singapore, Thailand, Malaysia dan Phillipines, mereka punya buku tentang karang di negara mareka masing-masing sejak decade 1980-an.

Tetapi masalah yang sangat mendasar tertinggalnya ilmuwan karang di Indonesia adalah pola berpikir kabanyakan orang Indonesia yang cenderung melihat keuntungan jangka pendek belaka. Mempelajari karang Karakteristik Lingkungan, Ekstraksi dan Daya Hambat Mikrosimbion [88] 
tidak langsung memberikan keuntungan ekonomi seperti halnya orang mempelajari ikan. Tetapi karang mempunyai peranan yang sangat penting dalam keberlajutan perikanan laut. Jika pola pikir semacam ini terus dipertahankan bukan mustahil jika ketika banyak mahasiswa dan ilmuwan mulai menyadari pentingnya karang dalam ekologi laut ataupun dalam ekonomi (pariwisata), Pada saat itu karang di Indonesia sudah rusak berat.

Kurangnya buku tentang karang di Indonesia dan sedikitnya mahasiswa Indonesia yang mau dan mampu membaca publikasi berbahasa Inggris membuat pemahaman orang Indonesia tentang karang sangat lemah. Salah satu kelemahan yang mendasar adalah kerancuan pemahaman tentang istilah-istilah yang memang sangat mirip satu dengan lainnya.

\section{2. 5. Karang dan Terumbu Karang}

Karang dan terumbu karang dalam pembicaraan sehari-hari karang biasa diartikan sebagai batu yang keras (rock). Dalam istilah biologi laut, karang diartikan sebagai hewan invertebrata dari ordo Scleractinia (Cnidaria, Anthozoa) yang biasanya hidup sesil di dasar laut, yang dalam istilah bahasa Inggris disebut coral, sedangkan terumbu karang (coral reef) bagi peneliti Biologi mempunyai arti sebagai suatu ekosistem yang biasanya didominasi oleh komunitas karang, yaitu kelompok hewan sesil yang menghasilkan kapur. Sedangkan hewan-hewan lain yang hidup di dalam atau di sekitar terumbu karang disebut hewan terumbu karang (coral reef animal), misalnya cacing polycaheta, echinodermata dan crustacean.

\section{3. Habitat Spons dan Metabolik Sekunder}

5. 3. 1. Pengamatan Kondisi Habitat Spons

Keberadaan sampel sponge yang dominan pada setiap stasiun pengamatan dapat dilihat pada Tabel 5.3., dengan kondisi habitat yang dominan pada masing-masing sponge.

Pada Tabel 5.3, di bawah menunjukkan bahwa sponge jenis Callyspongia aeresuza terdapat pada stasiun I,II dan III, Callyspongia fallax didapatkan pada stasiun I dan pada stasiun II, masing-masing pada kedalaman dan kondisi habitat yang berbeda. Sedangkan Agelas sp didapatkan pada stasiun III dan stasiun IV pada kedalaman dan habitat 
yang berbeda. Jenis sponge yang lain (Agelas clathrodes dan Meloplus sarasinorum) terdistribusi masing-masing pada stasiun I dan II. Hal ini mengindikasikan bahwa kedua jenis sponge ini tidak dapat hidup pada habitat yang berbeda.

Tabel 5. 3. Jenis Sponge dan Habitat yang Dominan Pada Setiap Stasiun di Sekitar Pulau Kapoposan Kepulauan Spermonde.

\begin{tabular}{|l|c|l|l|}
\hline $\begin{array}{l}\text { Stasiun } \\
\text { Pengamatan }\end{array}$ & $\begin{array}{l}\text { Kedalaman } \\
(\mathrm{m})\end{array}$ & Jenis Sponge & Habitat Dominan \\
\hline \multirow{3}{*}{ Stasiun I } & 15 & Callyspongia aeresuza & karang hidup (encrusting) \\
\cline { 2 - 4 } & 7 & Agelas clathrodes & karang mati yang ditumbuhi alga \\
\cline { 2 - 5 } & 10 & Callyspongia fallax & karang hidup branching dan encrusting \\
\hline \multirow{3}{*}{ Stasiun II } & 6 & Callyspongia aerizusa & karang hidup massiv dan branching \\
\cline { 2 - 5 } & 10 & Callyspongia fallax & karang hidup encrusting dan massiv \\
\cline { 2 - 5 } & 5 & Meloplus sarasinorum & karang mati yang ditumbuhi alga \\
\hline \multirow{2}{*}{ Stasiun III } & 7 & Callyspongia aeresuza & karang hidup karang massiv \\
\cline { 2 - 4 } & 5 & Agelas sp & pasir dan pecahan karang \\
\hline Stasiun IV & 3 & Agelas sp & Lamun dan pasir \\
\hline
\end{tabular}

Distribusi spons sebagaimana dalam stasiun yang mengambarkan bahwa terdpat dua jenis spons yang kadang tidak dapat hidup dam kondisi habitat yang berbeda, sebagaimana ditunjukkan dalam Gambar 5.1., berikut:
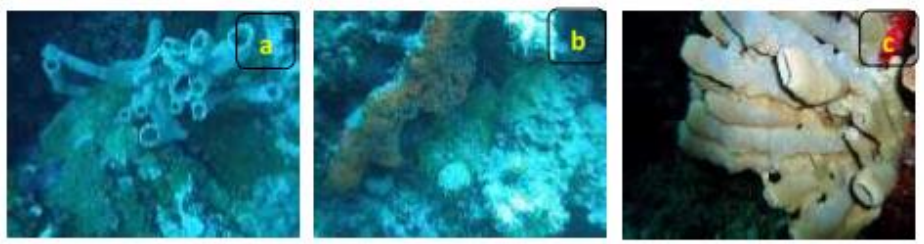

Gambar 5. 1. Sampel sponge stasiun I, a. Callyspongia aerizusa, b. Agelas clathrodes dan c. Callyspongia fallax; dan

Dari stasiun I, terdapat 3 jenis sponge yang berbeda, ketiga jenis sponge ini adalah Callyspongia aerizusa, Agelas clathrodes dan Callyspongia fallax. Sponge ditemukan hidup dan tumbuh pada habitat yang didominasi karang keras dan karang mati, dengan kondisi terumbu karang dalam kategori sedang.

Pada stasiun II terdapat sponge jenis Callyspongia aerizusa, dan jenis sponge yang lain yaitu jenis Meloplus sarasinorum. Jenis Agelas clathrodes tidak ditemukan pada stasiun ini, ketiga jenis sponge ini hidup dan tumbuh pada habitat yang didominasi karang keras dan karang mati dengan kondisi terumbu karang kategori rusak

Karakteristik Lingkungan, Ekstraksi dan Daya Hambat Mikrosimbion [90] 

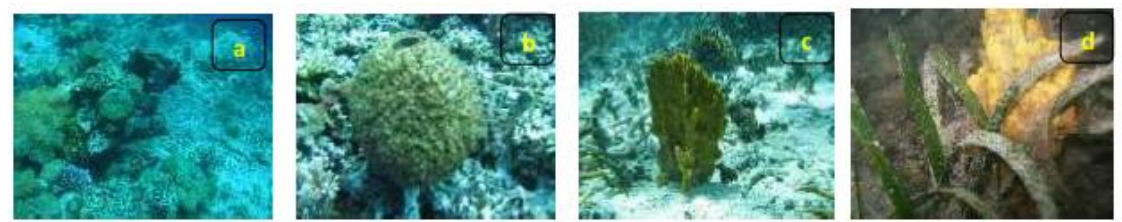

Gambar 5. 2. Sampel sponge stasiun II, a. Callyspongia aerizusa, b. Meloplus sarasinorum; sedangkan c Agelas sp yang ditemukan pada stasiun III; serta d. Agelas sp jenis lainnyayang dominan hidup pada Lamun dan Pasir Ditemukan pada Stasiun IV.

Terdapat perbedaan antara sponge Agelas clathrodes dan Meloplus sarasinorum, yaitu sponge jenis Agelas clathrodes berada pada stasiun I dan Jenis Meloplus sarasinorum berada pada stasiun II, yang berarti kedua jenis sponge ini hidup dengan kondisi terumbu karang yang berbeda, sedangkan jenis Callyspongia aerizusa, dan Callyspongia fallax dapat hidup pada stasiun I dan II. Diduga kedua jenis sponge ini dapat hidup dengan kondisi terumbu karang dengan kategori sedang dan rusak.

Jenis spons pada stasiun III dan IV adalah Callyspongia aerizusa dan Agelas sp, pada stasiun III jenis Callyspongia aerizusa dan Agelas sp hidup pada habitat yang didominasi oleh karang keras, pasir dan pecahan karang. Adapun kondisi terumbu karang pada stasiun III berada dalam kategori sedang. Pada stasiun IV jenis Callyspongia aerizusa tidak ditemukan lagi dan yang ada pada stasiun ini adalah sponge jenis Agelas $s p$. Jenis sponge ini tumbuh pada habitat yang didominasi lamun dan pasir, dengan kondisi terumbu karang berada dalam kondisi rusak.

\section{3. 2. Pengamatan Kandungan Metabolit Sekunder Spons}

Skrining dengan padanan kata penelusuran diartikan sebagai cara atau metode deteksi dini atau usaha yang mengidentifikasi karakteristik khusus yang ada pada suatu objek dan dilakukan secara cepat. Misalnya spons, bakteri atau mikroorganisme lainnya yang hidup secara simbiosis. Skrining terhadap aktivitas anti-mikroba mikrosimbion spons dilakukan dengan uji bakteri menggunakan bakteri Escherichia coli dan Staphylococcus aureus, dan uji jamur menggunakan Candida albicans dan Malassezia furfur. Kandungan senyawa bioaktif dari metabolit sekunder spons yang berasal dari Pulau Kapoposan, berdasarkan zona hambatnya, dapat dilihat pada Tabel 5.4.

Dari tabel tersebut terlihat bahwa kandungan senyawa spons berdasarkan kelompok dapat dijadikan sebagai acuan dalam mengetahui 
senyawa yang terkandung dalam spons pada sampel penelitian. Dari kelompok sponge Callyspongidae, diketahui mengandung senyawa Linear 3-alkylpiperidines dan kelompok Agelasidae mengandung Pyrrole2-carboxylic derivates, selain itu juga terdapat kelompok Agelas dengan kandungan Di-dan sesquiterpenes. Pada ekstrak methanol spons Agelas $s p$ ditemukan kandungan Agelasidine-A terdiri dari senyawa guanine dan sulphone.

Tabel 5.4 Senyawa Bioaktif yang Dihasilkan Spons Laut Menurut Soest dan Braekman (1999).

\begin{tabular}{|l|l|}
\hline \multicolumn{1}{|c|}{ Senyawa } & \multicolumn{1}{c|}{ Kelompok Spons } \\
\hline Peroxy-polyketides & Homosclerophorida (9) \\
Steroid amines & Plakina- Corticium (2) \\
Triterpenes & Astrophorida (8) \\
Penaresidins & Stelletta (4) \\
Sulfated sterol & Penares (2) \\
Aaptamines & Pachastrellidae (2) \\
$4,8,12$ - trimethyltridecanoid acid & Subberetidae (3) \\
Clionamides & Cliona (2) \\
Peroxy-sesterterpenoids & Latrunculiidae (4) \\
Pyrrologuinoline alkaloids & Latrunculiidae (5) \\
Pyrrole-2-carboxylic derivates & Axinellidae-Agelasidae Ceratoporellidae(26) \\
Isocyanoterpene & Axinellidae- Bubaridae-Halichondridae(32) \\
Sulafated sterol & Halichondriidae (9) \\
Di-dan sesquiterpenes & Agelas (6) \\
Linear 3- alkylpiperidines & Niphatidae + Callyspongidae(6) \\
Keterangan : Angka dalam kurung pada kolom kedua adalah jumlah jenis/genus.
\end{tabular}

Tabel 5.4, di atas memperlihatkan dinamika yang terjadi pada setiap jenis spons yang berakibat pada produksi zat aktif yang sangat bervariasi. Pembentukan zat aktif pada setiap jenis spons menempuh mekanisme yang berbeda satu terhadap yang lainnya, yang banyak dipengaruhi oleh ketersediaan nutrisi, adanya predator, kondisi atau status terumbu karang (kondisi rusak, baik), kekeruhan, sehingga akan berdampak pada dinamika pertumbuhan dan perkembangan spons termasuk jenis dan jumlah mikrosimbion yang berasosiasi dengannya. Keadaan ini juga akan berdampak pada karakterisitik bakteri simbion, apakah memiliki kemampuan sebagai anti bakteri dan jamur ataupun tidak memiliki aktivitas terhadap mikroorganisme tersebut. Semua ini terjadi karena adanya perbedaan dari produksi zat aktif yang dapat dihasilkan oleh spons dan mikrosimbionnya sebagai bentuk dari adaptasi diri untik dapat bertahan hidup pada suatu habitat dengan karakteristik tertentu. Hal 
ini dapat dikatakan bahwa peramalan tentang jenis zat aktif, sifat aktivitas anti bakteri dan jamur serta jenis dan jumlah mikrosimbion terhadap spons sangat sulit diprediksi. Tabel 5. 5, di bawah memperlihatkan tentang sifat aktivitas mikrosimbion spons terhadap beberapa jenis bakteri dan jamur.

Tabel 5. 5. Diameter Hambatan Hasil Skrining Aktivitas Antimikroba Ekstrak Pada Spons Dengan Konsentrasi $1000 \mu \mathrm{g} / \mathrm{ml}$.

\begin{tabular}{|c|c|c|c|c|c|}
\hline \multirow{3}{*}{ Stasiun } & \multirow{2}{*}{ Kode Sampel } & \multicolumn{3}{|c|}{ Diameter Hambatan (mm) Ekstrak Metanol. } \\
\cline { 3 - 6 } & & \multicolumn{2}{|c|}{ Bakteri } & \multicolumn{2}{|c|}{ Jamur } \\
\cline { 3 - 6 } & & EC & SA & CA & EC \\
\hline \multirow{3}{*}{ I } & A & 11,88 & I & A & 11,88 \\
\cline { 2 - 6 } & B & 16,48 & & B & 16,48 \\
\cline { 2 - 6 } & C & 9,55 & & C & 9,55 \\
\hline \multirow{3}{*}{ II } & D & 10,60 & II & D & 10,60 \\
\cline { 2 - 6 } & E & - & & E & - \\
\cline { 2 - 6 } & F & 18,91 & & F & 18,91 \\
\hline \multirow{2}{*}{ III } & G & 16,81 & III & G & 16,81 \\
\cline { 2 - 6 } & H & 12,26 & & H & 12,26 \\
\hline IV & I & - & IV & I & - \\
\hline
\end{tabular}

Keterangan : A : Callyspongia aerizusa; B : Agelas clathroides; C Callyspongia fallax; D : Callyspongia aerizusa; $\mathrm{E}$ : Callyspongia fallax; $\mathrm{F}$ : Meloplus sarasinorum; G : Callyspongia aerizusa; H : Agelas sp dan I : Agelas sp*; dan beberapa jenis bakteri dan jamur EC : Escherichia coli; SA : Staphylococcus aureus; CA : Candida albicans; MF : Malassezia furfur

Tabel 5. 5. di atas juga memperlihatkan nilai diameter hambatan untuk bakteri uji Escherichia coli berkisar 9,55 mm - 18,91 mm dan nilai hambatan untuk bakteri uji Staphylococcus aureus berkisar 11,70 mm 19,96 mm. Pada Uji bakteri Escherichia coli dan Staphylococcus aureus tersebut, Meloplus sarasinorum memiliki daya hambat terbesar, sedangkan Callyspongia fallax pada stasiun I memiliki daya hambat terkecil. Besarnya daya hambat Meloplus sarasinorum menunjukkan bahwa spons jenis ini memiliki kandungan senyawa bioaktif tersebut berupa triterpenoid. Besarnya daya hambat jenis spons ini terkait dengan habitat spons tersebut. Besarnya kandungan metabolit pada spons ini diduga oleh banyaknya predator, sehingga sponge jenis ini banyak mengalami stress dan dalam mempertahankan diri spons ini memiliki senjata perisai menghasilkan senyawa kimia membentuk metabolit sekunder yang dapat meracuni predator disekitarnya karena bersifat toksik.

Pada uji jamur Candida albicans semua jenis sponge tidak memiliki daya hambat kecuali Meloplus sarasinorum, diduga hal ini Karakteristik Lingkungan, Ekstraksi dan Daya Hambat Mikrosimbion [93] 
disebabkan karena jamur Candida albicans mempunyai struktur dinding sel yang kompleks, dengan ketebalan 100-400 nm, selain itu dinding sel dari jamur ini terdiri atas 5 lapisan yang berbeda. Pada uji jamur Malassezia furfur daya hambat berkisar 9,88 mm - 20,94 mm, selain itu juga kandungan sponge Meloplus sarasinorum dari triterpenoid terdapat senyawa saponin yang dapat mengganggu perkembangan protozoa dengan terjadinya ikatan antara saponin dengan sterol pada permukaan membran sel protozoa sehingga menyebabkan membran pecah dan sel lisis akan mati. Keberadaan kolesterol pada membran sel eukariotik (termasuk protozoa), tetapi tidak terdapat pada sel bakteri prokariotik, saponin mempunyai tingkat toksisitas yang tinggi melawan jamur, mekanisme kerjanya sebagai anti jamur berhubungan dengan interaksi saponin dengan sterol membran.

Pada uji jamur Malassezia furfur sponge Agelas clathroides memiliki daya hambat terbesar dan daya hambat terkecil dimiliki oleh Callyspongia aerizusa. Pada uji jamur Malassezia furfur sponge Agelas clathroides memiliki daya hambat terbesar, karena adanya kandungan senyawa pada kelompok sponge Agelas yaitu seskiterpenoid yang merupakan anti jamur, selain itu juga besarnya bioaktifitas sponge tersebut disebabkan oleh adanya kandungan kimia senyawa tersebut sebagai imunosupressive, neurosupressive dan anti virus.

Callyspongia fallax yang didapatkan pada stasiun II dan Agelas sp pada stasiun IV tidak memiliki daya hambat baik pada uji bakteri maupun pada uji jamur, hal ini diduga disebabkan karena kondisi terumbu karang yang tidak memungkinkan bagi pertumbuhan sponge tersebut dimana berhubungan dengan penyerapan senyawa yang terkandung pada lingkungan sekitarnya. Hasil pengamatan kondisi terumbu karang serta habitat yang dominan pada sampel uji dengan daya hambat pada mikroba uji maka dapat dibandingkan dengan menggunakan gambar histogram berdasarkan genus yang sama. 


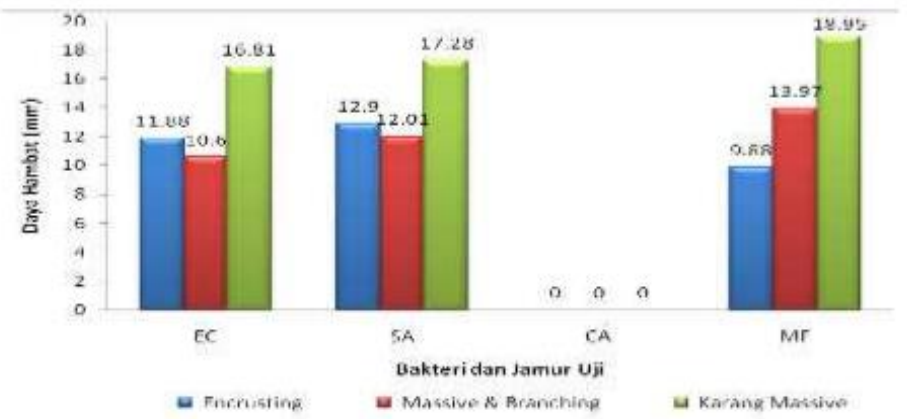

Gambar 5.3. Histogram kondisi habitat yang dominan dengan diameter hambatan pada mikrosimbion spons Callyspongia aeresuza pada stasiun I, II dan III yang ditentukan pada area Pulau Kapoposan, Kepulauan Spermonde.

Gambar 5. 3, di atas terlihat bahwa sponge Callyspongia aeresuza yang hidup pada kondisi habitat yang didominasi karang massive pada uji bakteri dan uji jamur dengan menggunakan jamur Malassezia furfur memiliki daya hambat paling besar dibandingkan dengan kondisi habitat yang lain, sedangkan pada uji jamur Candida albicans tidak memiliki daya hambat. Kondisi habitat yang didominasi oleh encrusting dan campuran karang massive dan branching pada uji bakteri memiliki daya hambat yang tidak terlalu jauh berbeda. Tingginya nilai daya hambat kondisi habitat yang didominasi oleh karang massive pada uji bakteri dan jamur kecuali uji jamur Candida albicans disebabkan oleh karang massive tergolong jenis hard coral non acropora dimana kondisi tersebut didukung dengan kondisi terumbu karang yang tergolong kategori sedang sehingga pertumbuhan sponge sangat baik, kondisi tersebut juga dipengaruhi oleh beberapa faktor oceanografi antara lain posisi terumbu karang yang menghadap arah angin, sehingga arus dari arah laut lepas mensuplai banyak makanan dan mempertinggi difusi oksigen dari udara bebas.

Hal lainnya yang memberi efek yakni tingginya persentase karang hidup yang menyebabkan sponge bersaing dengan karang hidup dan untuk menciptakan pertahanan diri spons menghasilkan senyawa kimia membentuk metabolit sekunder yang ditakuti dan dihindari dari predator, senyawa tersebut bersifat toksik dan berkhasiat juga sebagai antikanker (cytotoxic) dan antibiotik.

Besarnya daya hambat bakteri Staphylococcus aureus dibandingkan bakteri Escherichia coli pada disebabkan karena perbedaan 
bioaktivitas yang dipengaruhi oleh beberapa faktor. Salah satu faktor yang mempengaruhi bioaktivitas adalah adanya resistensi bakteri yang disebabkan oleh perbedaan struktur dinding selnya. Bakteri Staphylococcus aureus merupakan bakteri gram positif dimana struktur dinding selnya lebih sederhana, dibanding bakteri Escherichia coli yang merupakan bakteri gram negatif dengan struktur dinding sel lebih kuat dan lebih kompleks, sehingga sulit untuk diuaraikan. Bakteri gram negatif mempunyai struktur dinding sel yang tebal dan berlapis-lapis terdiri atas lipoprotein, peptidoglikan dan lipopolisakarida, lapisan inilah yang menyebabkan dinding sel tidak mudah dipisahkan dari sel bakteri oleh senyawa aktif.

Daya hambat kondisi habitat brancing \& encrusting pada bakteri uji Staphylococcus aureus memiliki nilai hambat lebih besar dibanding pada bakteri uji Escherichia coli. Pada jamur uji, kedua kondisi habitat tidak memiliki daya hambat. Hal ini disebabkan oleh kondisi habitat yang didominasi oleh branching dan encrusting didukung oleh kondisi terumbu karang kategori sedang dimana komponen yang mendominasi pada habitat ini juga mendukung dalam pertumbuhan sponge sehingga dalam persaingan pemanfaatan nutrient semakin banyak yang dapat disaring untuk dapat dijadikan makanan atau simbionnya yang akan meningkatkan bioaktivitas zat aktif yang diproduksi. Nutrien yang tersaring oleh spons sangat kecil bahkan seukuran bakteri, sponge juga dapat menyaring air sebanyak 4 hingga 5 kali volume tubuhnya, yang menguatkan bahwa jenis dan karakter zat aktif yang dapat diproduksi oleh spons sangat bervariasi.

Uraian ini menunjukkan bahwa kandungan metabolit sekunder spons sangat dipengaruhi kondisi habitat yang didukung oleh kondisi terumbu karang. Fenomena ini juga dipengaruhi oleh faktor adaptasi spons terhadap kondisi lingkungan dimana struktur tubuh spons dalam menyaring makanan, oksigen serta mengeluarkan makanan dan $\mathrm{CO}_{2}$. Dalam penyaringan tersebut, ribuan sampai jutaan mikroba terperangkap, apabila konsentrasi mikroba sangat besar maka sponge dapat terkena infeksi dan sakit, oleh karena itu perlu memproduksi senyawa kimia yang mampu melumpuhkan mikroba yang terperangkap. Mikroba yang resisten terhadap senyawa kimia tersebut akan bertahan dan hidup \pm Zat aktif atau senyawa kimia yang merupakan metabolit sekunder tersebut dirancang untuk melawan pertumbuhan sel yang sangat cepat, mirip ciri-ciri Karakteristik Lingkungan, Ekstraksi dan Daya Hambat Mikrosimbion [96] 
pertumbuhan sel kanker, selain itu juga dipengaruhi oleh akibat interaksi dengan lingkungan sekitar baik lingkungan biotik maupun abiotik. Sponge mentoleransi mikroorganisme yang masuk ke dalam pori-porinya karena mikroorganisme menyediakan sumber makanan atau produk metabolit tertentu yang bermanfaat untuk spons.

\section{4. Ekstraksi Spons}

Ekstraksi adalah salah satu metode pemisahan suatu komponen dengan komponen lainnya yang umumnya dilakukan dengan menggunkanan pelarut tertentu yang spesifik dengan komponen yang menjadi target atau ekstrak. Metode ekstraksi cukup bervariatif, salah satunya sebagai contoh berikut ini:

Ekstraksi spons laut Callyspongia sp dilakukan dengan cara Sampel spons ditimbang, dipotong- potong kemudian dimaserasi dengan etanol 96\% selama 24 jam dengan perbandingan 1:2 (w/v). Setelah itu, sampel disaring sehingga diperoleh debris I dan filtrat I. Filtrat I dikumpulkan dalam wadah, sedangkan debris I dimaserasi lagi dengan etanol 96\% selama 24 jam lalu disaring, sehingga memperoleh debris II dan filtrat II. Debris II diberikan perlakuan yang sama dengan sebelumnya hingga diperoleh debris III dan filtrat III. Filtrat III yang diperoleh digabungkan dengan filtrat I dan II, lalu disaring. Sebagian filtrat yang telah disaring diuapkan dengan rotary vacuum. Evaporator pada temperatur $400{ }^{\circ} \mathrm{C}$ sampai etanol menguap. Filtrat lainnya dievaporasi di dalam oven. Bagian sisa dari penguapan etanol disebut ekstrak pekat. Ekstrak pekat disimpan dalam referigerator dengan suhu $40{ }^{\circ} \mathrm{C}$.

Ekstraksi spons dilakukan dengan cara, ditiriskan dari rendaman etanol, dicuci dengan air mengalir dan dikeringkan. Spons dipotong dan dimaserasi dengan kloroform. Pendiaman dilakukan selama 24 jam. Setelah pendiaman kemudian disaring dan dikumpulkan dalam wadah tertentu, disebut filtrat I, atau Sampel Spons jenis tertentu diekstraksi dengan metode maserasi menggunakan kloroform. Pada awal penyarian pelarut berwarna hijau tua. Penyarian dihentikan setelah ekstrak kloroform berwarna jernih yang berarti sebagian besar senyawa yang larut dakam kloroform sudah terekstrak. Residu sebagai sisa penyaringan (penyarian) diekstraksi seperti cara di atas hingga \pm 3 kali (warna bening). Filtrat (1, 2, dan 3) disatukan, kemudian diuapkan dengan penguap putar 
hampa udara (evaporator), hingga diperoleh ekstrak kental dan dianginanginkan kering. Ekstrak kering yang diperoleh ditimbang dan disebut ekstrak kloroform (nama ektrak sesuai dengan larutan pengektrak). Terhadap sisa spons diekstraksi seperti cara di atas dengan menggunakan pelarut metanol. Ekstrak kloroform dan ekstrak metanol yang diperoleh diuji sifat toksiknya dengan bioassay.

Fraksinasi dengan kromatografi cair hampa udara, lalu diisolasi senyawa aktif gabungan fraksi. Fase diam yang digunakan biasanya silika gel F60 preparatif dan fase gerak dengan kepolaran bertingkat yaitu: heksana, campuran heksan-etil asetat, misalnya kombinasi perbandingan $(9: 1,8: 2,7: 3,6: 4,5: 5,4: 6,3: 7,2: 8,1: 9 \mathrm{v} / \mathrm{v})$, etil asetat, kloroform-metanol umumnya, (1:1 v/v) dan metanol. Campuran ekstrak kloroform dan silika gel G254 preparatif ditempatkan diatas penyaring glas sinter yang telah berisi silika gel F60 preparatif. Filtrasi dilakukan dengan pengurangan tekanan udara. Filtrat yang dihasilkan diuapkan hingga kering, ditimbang dan dibuat seri konsentrasi untuk uji.

Berat basah spons $3115.3 \mathrm{~g}$, diperoleh 6,15 g ekstrak kering spons. Sisa spons kemudian dimaserasi lagi menggunakan pelarut metanol. Ekstrak metanol yang diperoleh sebanyak 9, 1 g ekstrak kering. Ekstrak etanol hasil maserasi spons dilakukan preparasi dengan penyaringan dan perendaman pada suhu $4{ }^{\circ} \mathrm{C}$ selama 24 jam. Hal ini dilakukan untuk menghilangkan garam-garam yang terlarut. Setelah diupkan filtrat kental yang diperoleh dipartisi dengan kloroform. Filtrat kloroform diuapkan dan diperoleh 3, 98 g ekstrak kering kloroform. Pemeriksaan kandungan ekstrak kloroform spons dan ekstrak kloroform dari perendaman etanol dengan KLT menunjukkan profil kromatogram yang relatif sama sehingga kedua ekstrak ini dapat digabung. Berat gabungan kedua ekstrak adalah 10, $02 \mathrm{~g}$ ekstrak kering atau rendemen total ekstrak sebesar 0,49 \% b/b spons basah.

\section{5. Daya Hambat Ekstrak Spons Sebagai Anti Bakteri dan Jamur}

Banyaknya penyakit infeksi yang disebabkan oleh mikroba merupakan masalah dasar yang harus ditangani. Berbagai cara yang dilakukan untuk pengobatan berbagai jenis penyakit infeksi yaitu dengan cara pemberian obat antibiotik. Tingginya kasus infeksi serta penggunaan 
obat antibiotik yang tidak tepat atau terus menerus akan menyebabkan resisten mikroba terhadap antibiotik.

Spons mempunyai potensi bioaktif yang belum banyak dimanfaatkan dalam berbagai kepentingan dan menghasilkan senyawa bioaktif yang sangat besar di antara invertebrata laut lainnyaHiingga saat ini banyak penelitian yang melakukan uji senyawa pada biota laut yang mempunyai manfaat terhadap suatu penyakit. Spons termasuk biota laut yang menghasilkan senyawa metabolit sekunder yang memiliki peranan yang sangat potensial dalam bidang farmasi berpotensi obat. Senyawasenyawa yang telah berhasil diisolasi dari beberapa jenis porifera di antaranya adalah alkaloid, terpenoid, acetogenin, senyawa nitrogen, halida siklik, peptide siklik dan lain-lain.

Beberapa hasil kajian terkait daya hambat ekstrak spons menunjukkan senyawa metabolit yang berhasil diisolasi dari jenis-jenis Spons yang memiliki aktifitas. Senyawa bioaktif yang dihasilkan Spons merupakan salah satu proses adaptasi untuk mekanisme pertahanan diri. Senyawa bioaktif tersebut merupakan senyawa kimia yang disebut senyawa metabolit sekunder yang digunakan untuk menghindari diri dari serangan predator dan media kompetisi dengan spesies lain. Senyawa yang dihasilkan porifera merupakan respon terhadap kompetisi lingkungannya. Produk senyawa yang dihasilkan porifera merupakan hasil dari simbiotik antara beberapa organisme seperti alga, bakteri dan lainlain. Lingkungan dari porifera sangat mempengaruhi proses pertumbuhan porifera karena dilihat dari sifat makan dari hewan ini yaitu menyaring makanan (filter feeder). Tiap jenis spons menghasilkan senyawa metabolit yang berbeda. Senyawa metabolit sekunder mempunyai manfaat yang berbeda tergantung jenis senyawanya yaitu sebagai antikanker, antibakteri, antijamur dan lain-lain. Berdasarkan hal tersebut maka perlu dilakukan penelitian untuk mengetahui porifera yang mempunyai kemampuan sebagai antibakteri.

\section{5. 1. Metode Kerja}

Metode yang dapat digunakan dalam menentukan daya hambat suatu ektrak termasuk ektrak spons. Peralatan yang umum digunakan dalam uji daya hambat adalah timbangan analitik, aluminium foil, sendok, gelas erlenmeyer $500 \mathrm{ml}$, gelas ukur $100 \mathrm{ml}$ dan $500 \mathrm{ml}$, pelat pemanas, batang 
pengaduk bermagnet, tabung reaksi, cawan petri, gelas piala $100 \mathrm{ml}$, autoklaf, kompor, kawat ose, lampu bunsen, kapas, korek api, rak tabung, mortar dan pestel, mikro pipet, tabung Eppendorf, laminar flow, inkubator, evaporator, pinset, kertas saring, kertas label, kertas cakram 5 $\mathrm{mm}$, lemari pendingin, penggaris, jangka sorong, sarung tangan dan kamera. Bahan-bahan yang digunakan yaitu ekstrak porifera, biakan murni bakteri Escherichia coli dan Staphylococcus aureus, medium Nutrient Broth (NB), medium Nutrient Agar (NA) dan larutan metanol lisol (antiseptik).

Pengujian daya hambat diawali dengan pembiakan bakteri. Biakan bakteri Escherichia coli dan Staphylococcus aureus (paling sering digunakan sebagai bakteri uji), diinokulasi secara aseptik ke dalam tabung reaksi yang sudah berisi $5 \mathrm{ml}$ medium NB. medium tersebut diinkubasi selama 24 jam pada suhu $37{ }^{\circ} \mathrm{C}$, kemudian diinokulasi lagi dari medium NB ke medium NA miring lalu diinkubasikan selama 24 jam lalu disimpan sebagai stok dari kedua bakteri tersebut.

Langka selanjutnya adalah pembuatan ekstrak spons. Dilakukan dengan mengambil sampel spons yang diperoleh pada Pulau Kodingareng Keke, gugusan Kepulauan Spermonde diidentifikasi, kemudian dibersihkan dan dicuci dengan air laut lalu dimasukkan dalam wadah dan diawetkan di dalam cool box yang berisi es. Setelah sampai di laboratorium masing-masing sampel spons dikeluarkan dari cool box. Setiap sampel spons dipotong-potong kecil sebanyak 200 g dan dimasukkan dalam wadah maserasi, kemudian ditambahkan metanol sebanyak $100 \mathrm{ml}$. Setelah 24 jam pelarut diganti dengan metanol yang baru. Ini dilakukan sebanyak 3 kali dengan jumlah pelarut yang sama. Ekstrak metanol yang diperoleh dikumpulkan dan diuapkan dengan menggunakan evaporator. Ekstrak kental yang diperoleh dikeringanginkan sampai mendapatkan ekstrak kering porifera. Ekstrak metanol yang diperoleh diberi perlakuan dengan konsentrasi yang berbeda-beda yaitu 30\%, 60\% dan 90\%. Selanjutnya digunakan sebagai sampel uji aktivitas antimikroba.

\section{a. Fraksinasi Senyawa Bioaktif}

Fraksinasi dilakukan untuk memisahkan senyawa kimia yang satu dengan senyawa kimia yang lain dari suatu ekstrak bahan alam. Metode 
fraksinasi yang digunakan adalah metode kromatografi dimana pemisahan senyawa kimia tergantung pada sifat partisi, adsorpsi, dan distribusi komponen kimia terhadap fase diam dan fase gerak. Beberapa metode fraksinasi yang digunakan antaralain kromatografi kolom vakum (KKV), kromatografi kolom gravitasi (KKG) dan kromatografi kolom tekan (KKT).

\section{b.. Uji Bioaktivitas Senyawa Metabolit Sekunder}

Dipermukaan bumi ini terdapat ratusan ribu spesies yang masingmasing berpotensi mengandung metabolit sekunder yang unik. Dengan demikian jumlah senyawa metabolit sekunder pun sangat banyak di antaranya ada yang mempunyai aktivitas biologis dan ada pula yang tidak aktif biologis. Oleh karena itu perlu dilakukan uji bioaktivitas senyawa metabolit sekunder hasil ekstraksi.

\section{c. Uji AntiMikroba}

Pemakaian antibakteri yang berlebihan menyebabkan mikroba yang semula sensitif terhadap antibiotik menjadi resisten. Oleh karena itu, senyawa antibakteri diperlukan untuk mengatasi bakteri resisten tersebut. Disamping itu juga perlu pengembangan antiseptik dan disinfektan baru yang lebih aman bagi kulit dan jaringan manusia. Metode uji antimikroba dari tumbuhan.

Sampel diekstrak menggunakan pelarut yang sesuai. Ekstrak bisa dilakukan dengan perendaman, soklet, dan lainnya. Pelarut yang digunakan akan bisa bervariasi dan tergantung dengan senyawa target dan biasanya etanol. Ekstrak dipekatkan dan dikeringkan.

Larutan stock (dalam air atau etanol $85 \%$ ) dengan konsentrasi 1000 $\mathrm{mg} / \mathrm{ml}$ disiapkan. Larutan stock adalah larutan ekstrak yang diuji bioaktivitasnya. Larutan ini nantinya akan diencerkan dengan air hingga diperoleh konsentrasi yang diketahui.

Ada dua metode difusi yang digunakan yaitu metode cakram kertas dan metode sumur. Adanya aktivitas antibakteri ditandai dengan terbentuknya zona bening di sekitar sumur dan cakram. Tahap pengujian awal digunakan metode cakram kertas (disc diffusion Kirby Bauer) yaitu kertas cakram dengan diameter $6 \mathrm{~mm}$ direndam ke dalam larutan spons uji kemudian diletakkan di atas permukaan media MHA lalu diinkubasi 
selama $1 \times 24$ jam pada suhu $37{ }^{\circ} \mathrm{C}$. Setelah muncul zona bening dilakukan pengujian lanjut dengan menggunakan metode sumur (metode modifikasi Kirby Bauer). Larutan spons uji dievaporasi hingga kering lalu dilarutkan dengan etanol sebanyak $4 \mathrm{ml}$, kemudian dimasukkan ke dalam tiga buah sumur berdiameter $6 \mathrm{~mm}$. Sumur ke empat diisi dengan etanol sebagai kontrol positif dan sumur kelima diisi dengan larutan kloramfenikol sebagai kontrol positif. Selanjutnya media diinkubasi selama 1x24 jam pada suhu $37^{\circ} \mathrm{C}$.

Berdasarkan hasil uji antivitas antibakteri menggunakan ekstrak spons, terlihat bahwa ekstrak memperlihatkan adanya aktivitas antibakteri terhadap bakteri uji Staphylococcus aureus dan Eschericia coli. Hasil pengukuran rerata diameter zona hambat ekstrak spons uji dan antibiotic. Hasil ini memperlihatkan bahwa ekstrak spons Dictyonella funicularis dan Phyllospongia lamellosa memiliki daya hambat terhadap kedua bakteri uji. Namun ekstrak spons Dictyonella funicularis memiliki aktivitas antibakteri yang lebih kuat dibandingkan ekstrak spons Phyllospongia lamellosa. Hal ini ditunjukkan dengan adanya perbedaan daya hambat yang muncul. Kedua ekstrak spons menunjukkan adanya aktivitas yang lebih kuat terhadap bakteri Escherichia coli. Sejauh ini pengendalian infeksi Gram negatif seringkali menjadi kendali dalam dunia kedokteran modern, hal ini diakibatkan oleh karakteristik bakteri kelompok Gram negatif memiliki dinding peptidoglikan yang cukup padat dan kompak serta adanyayaitu suatu mekanisme untuk mengeluarakn sanyawasenyawa yang tidak dibutuhkan dalam proses-proses biotransformasi seluler bakteri melalui sistem sekresi, sehingga menghambat proses internalisasi senyawa untuk mampu mempengaruhi mekanisme selular dari bakteri.

Kekuatan senyawa bioaktif yang terkandung dalam ekstrak spons laut dapat dilihat dengan menggunakan lebar diameter zona hambat sebagai parameternya. Semakin lebar diameter zona hambat yang terbentuk menandakan semakin kuatnya senyawa bioaktif tersebut menghambat pertumbuhan bakteri. Ekstrak Dictyonella funicularis memiliki senyawa antibakteri yang cukup kuat. Pada penelitian tersebut ekstrak Dictyonella incisa menunjukkan adanya aktifitas antibakteri terhadap bakteri Staphylococcus aureus. Ekstrak lainnya dari spons Phyllospongia lamellosa juga dipastikan memiliki senyawa antibakteri. 
Senyawa dari Phyllospongia lamellosa yang dapat menghambat pertumbuhan bakteri. Spesies Phyllospongia lamellosa yang diambil dari Perairan Bunaken juga memiliki kandungan senyawa antibakteri. Dibandingkan dengan antibiotik pembanding, diameter zona hambat yang terbentuk di sekitar ekstrak Dictyonella funicularis lebih besar. Hal ini menunjukan aktivitas antibakteri yang sangat tinggi pada bakteri uji Esherichia coli dan Staphylococcus aureus. Sehingga spesies ini dapat dikembangkan karena memiliki potensi sebagai obat antibakteri. Ekstrak Phyllospongia lamellosa juga menunjukkan aktivitas antibakteri moderat terhadap bakteri uji Eschericia coli dan Staphylococcus aureus, walaupun aktivitasnya masih sedikit lebih rendah dibandingkan dengan antibiotik pembanding. Pengamatan selama 2x24 jam dilakukan untuk melihat sifat dari ekstrak spons yang diuji, apakah bersifat bakteristatik, bakterisidal, atau bakterilitik. Hasil pada uji ini memperlihatkan bahwa kedua ekstrak spons uji bahwa zona bening yang terbentuk tidak jauh berbeda dengan pengamatan 1x24 jam. Hal ini berartri ekstrak spons yang diuji bersifat bakterisidal yaitu membunuh bakteri, tidak hanya mencegah mereka berkembang biak.

Persiapan biakan bakteri atau jamur uji. Bakteri dibiakan pada medium nutrien agar slant dan ragi atau jamur pada sabouroud agar slant. Inokulasi ini diinkubasi pada $37^{\circ} \mathrm{C}$ untuk bakteri dan $30^{\circ} \mathrm{C}$ untuk jamur. Mempersiapkan medium agar pada cawan petri untuk uji bioaktivitas. Uji bioaktivitas antibiotik dari ekstrak dapat dilakukan dengan tiga metode yaitu:

\section{a. Metode difusi}

Dengan metode difusi ini, ekstrak uji yang diserap dengan kertas saring dimasukkan ke dalam silinder atau dimasukkan ke dalam lubang, dikontakkan dengan media yang telah diinokulasi. Kemudian setelah diinkubasi, diameter daerah bening disekitar reservoir diukur. Diameter daerah bening ini merupakan daerah inhibisi dari ekstrak sampel terhadap mikroba uji. Untuk menurunkan limit deteksi, sistem dibiarkan pada suhu rendah selama beberapa jam sebelum diinokulasi, yaitu untuk memberikan kesempatan kepada antibiotik untuk berdifusi sebelum mikroba tumbuh. 


\section{b. Metode pengenceran}

Pada metode pengenceran, sampel yang diuji dicampur dengan medium yang cocok yang sebelumnya telah diinokulasi dengan mikroba uji. Setelah diinkubasi, pertumbuhan mikroba dapat ditentukan dengan cara visual atau dengan perbandingan turbidimetri dari kultur uji dengan kultur kontrol. Kultur kontrol adalah metode penumbuhan yang tidak diberi sampel yang akan diuji bioaktivitasnya.

\section{c. Metode bioautografi}

Merupakan metode untuk menentukan tempat (posisi) senyawa yang mempunyai aktivitas mikroba pada kromatogram. Caranya adalah dengan memindahkan senyawa uji dari kromatogram lapis tipis atau kertas ke medium agar yang sudah diinokulasi dengan mikroba uji. Daerah inhibisi kemudian diamati seperti di atas.

\section{5. 2. Pengujian Daya Hambat Ekstrak Spons Terhadap Aktivitas Antibakteri \\ Pengujian efektivitas bakteri dilakukan menggunakan metode} Kirby-Bauer atau dikenal dengan metode Paper disk, yaitu mengamati dan mengukur zona hambat ekstrak spons. Inokulum dari masing-masing bakteri Escherichia coli dan Staphylococcus aureus diambil secara aseptik sebanyak $1 \mathrm{ml}$ dari medium NB dan dituangkan ke cawan petri yang sudah berisikan medium NA. Setelah itu kertas cakram yang berukuran kira-kira $0,5 \mathrm{~mm}$ dicelupkan ke dalam ekstrak spons dengan konsentrasi yang berbeda yaitu 30\%, 60\% dan 90\%. Setelah itu dengan menggunakan pinset, kertas cakram diletakkan di atas masing-masing medium NA yang mengandung masing-masing bakteri S. aureus dan E. coli dan diinkubasikan pada temperatur $37^{\circ} \mathrm{C}$ selama $1 \times 24$ jam. Setelah itu semua media diinkubasi selama 24 jam pada temperatur $37^{\circ} \mathrm{C}$ lalu diamati dan diukur diameter zona hambatannya sampai hari ketiga.

\section{5. 3. Analisis Diameter zona hambat}

Hasil uji rata-rata ekstrak spons menunjukkan ekstrak Callyspongia sp pada konsentrasi $25 \%$ dan $50 \%$, tidak menunjukkan adanya diameter zona hambat yang terbentuk di sekitar cakram kedua bakteri uji. Hal ini menunjukkan pada konsentrasi rendah ekstrak Callyspongia sp belum mampu merusak dinding sel bakteri S. aureus dan E. coli. Ekstrak yang 
tidak menunjukkan adanya aktivitas senyawa bioaktif bukan berarti ekstrak tersebut tidak aktif, tetapi kemungkinan dipengaruhi oleh konsentrasi sampel uji yang digunakan. Ekstrak Callyspongia sp pada konsentrasi $75 \%$ sudah memperlihatkan adanya aktivitas antibakteri atau zona hambat di sekitar cakram. Rata-rata diameter zona hambat yang terbentuk yaitu $7.67 \mathrm{~mm}$ untuk bakteri S. aureus dan $8.15 \mathrm{~mm}$ untuk bakteri E. Coli. Diameter zona hambat ekstrak Callyspongia sp terhadap bakteri Staphylococcus aureus dan Escherichia coli.

Berdasarkan penggolongan kategori kekuatan daya hambat dapat dikatakan bahwa kekuatan antibakteri ekstrak Callyspongia sp terhadap bakteri S. aureus dan E. coli pada konsentrasi $75 \%$ termasuk pada kategori sedang karena diameter daerah hambatan 5-10 mm termasuk kategori sedang, membuktikan bahwa pada konsentrasi tinggi ekstrak ini sudah memiliki mekanisme aktivitas antibakteri dalam membunuh atau sudah mampu merusak dinding sel kedua bakteri walaupun kekuatan daya hambatnya masih dikategorikan sedang.

Hasil yang berbeda yang ditunjukkan oleh ekstrak Haliclona sp (spons yang diperoleh dari Pantai Melawai, Balikpapan), terhadap bakteri E. coli, secara berturut-turut rata-rata zona hambat yang terbentuk yaitu $8.55 \mathrm{~mm}$ untuk konsentrasi $25 \%, 10.45 \mathrm{~mm}$ untuk konsentrasi $50 \%$ dan $17.15 \mathrm{~mm}$ untuk konsentrasi $75 \%$. Terlihat jelas bahwa ekstrak Haliclona sp lebih besar menghambat pertumbuhan bakteri S. aureus dibandingkan bakteri E. coli. Hal ini membuktikan bahwa ekstrak Haliclona sp mempunyai senyawa bioaktif yang lebih cocok ke bakteri Gram positif dibandingkan bakteri Gram negatif. Bakteri S. aureus sendiri merupakan Gram positif yang memiliki struktur lapisan dinding sel yang tebal dan berlapis dua yang terdiri atas membran dalam dan peptidoglikan. Bakteri E. Coli merupakan Gram negatif yang memiliki struktur lapisan dinding sel berlapis tiga yang terdiri dari membran luar, peptidoglikan dan membran bagian dalam. Berdasarkan penggolongan kategori kekuatan daya hambat. Konsentrasi $25 \%$ ekstrak Haliclona sp terhadap bakteri S. aureus tergolong pada kategori kuat.

Hasil uji rata-rata untuk ekstrak Agelas sp (jenis spons yang diperoleh dari Pulau Kapoposan), terhadap bakteri S. aureus menunjukkan diameter zona hambat hanya pada konsentrasi $75 \%$, sedangkan pada konsentrasi $25 \%$ dan $50 \%$ tidak menunjukkan adanya zona hambat di

Karakteristik Lingkungan, Ekstraksi dan Daya Hambat Mikrosimbion [105] 
sekitar cakram. Diameter zona hambat konsentrasi $75 \%$ yang ditunjukkan oleh ekstrak spesies ini yaitu $8,65 \mathrm{~mm}$, menunjukkan ekstrak spons Agelas sp hanya mampu menghambat bakteri S. aureus pada konsentrasi tinggi, sedangkan pada konsentrasi rendah ekstrak ini tidak dapat menghambat pertumbuhan bakteri. Konsentrasi yang digunakan merupakan salah satu faktor yang mempengaruhi besar kecilnya zona hambat yang terbentuk di sekitar cakram. Semakin lebar diameter zona bening yang terbentuk membuktikan kuatnya senyawa bioaktif itu menghambat pertumbuhan bakteri.

Hasil yang diperoleh terhadap pengujian daya hambat eksterak tiga jenis spons yang digunakan terhadap dua jenis bakteri menunjukkan kekuatan daya hambat yang berbeda signifikan khususnya Haliclona sp lebih kuat dibandingkan dengan ekstrak spons Callyspongia sp dan ekstrak Agelas sp. Hasil ini menunjukkan bahwa kondisi habitat spons berpengaruh terhadap kandungan senyawa bioaktif yang dihasilkan dari proses metabolit sekunder spons dan besarnya daya hambat yang dihasilkan berbeda sesuai dengan kondisi habitatnya.

\section{5. 4. Uji Sitotoksisitas Ekstrak Senyawa Aktif Spons Kaliapsis sp}

Contoh analisis ekstrak spons Kaliapsis sp, dapat dilihat pada hasil KLT ekstrak kloroform dan ekstrak etanol menunjukkan profil kromatogram yang relatif sama sehingga kedua ekstrak ini dapat digabung. Gabungan kedua ekstrak berbobot 9,8 g, ekstrak kering atau rendemen total ekstrak sebesar $0,47 \%$ b/b spons basah. Pada uji pendahuluan sitotoksisitas untuk mengetahui aktivitas senyawa aktif perlu dilakukan uji terhadap ekstrak kloroform dan metanol. Tabel 5.6., berikut memperlihatkan toksisitas ekstrak kloroform terhadap sel myeloma jauh lebih besar bila dibandingkan dengan ekstrak methanol.

Tabel 5.6. Efek Sitotoksik ektram kloroform dan ektrak methanol terhadap sel myeloma

\begin{tabular}{llc}
\hline No & Nama ekstrak & Nilai IC $\mathrm{I}_{50}(\mu \mathrm{g} / \mathrm{mL})$ \\
\hline 1 & Kloroform & 16,8 \\
2 & Metanol & 164,9 \\
\hline
\end{tabular}

Fraksinasi ekstrak kloroform dan uji aktifitas fraksi-fraksi ekstrak kloroform dipartisi menjadi beberapa fraksi dengan metode kromatografi 
kolom hampa udara dengan sistem fase gerak bertingkat. Kromatografi kolom hampa udara atau kromatografi kolom cepat merupakan metode pemisahan yang cepat dan mudah dari suatu ekstrak. Penyarian dilakukan atas dasar perbedaan tingkat polaritas. Pemilihan fase gerak didasarkan atas profil KLT. Analisis KLT terhadap ekstrak kloroform menunjukkan pemisahan yang cukup bagus menggunakan fase gerak heksana : etil asetat $(5: 1 \mathrm{v} / \mathrm{v})$.

Gambaran berikut hasil kromatografi yang telah dilakukan maka sistem fase gerak yang digunakan untuk mengelusi senyawa berturutturut adalah sebagai berikut: Fraksi 1: Heksana 100\% $100 \mathrm{~mL}$; Fraksi 2: Heksana:etil asetat $=90: 10(\% \mathrm{v} / \mathrm{v}) 50 \mathrm{~mL}$; Fraksi 3: Heksana:etil asetat $=80: 20(\% \mathrm{v} / \mathrm{v}) 50 \mathrm{~mL}$; Fraksi 4: Heksana:etil asetat $=70: 30(\% \mathrm{v} / \mathrm{v}) 50$ $\mathrm{mL}$; Fraksi 5: Heksana:etil asetat $=60: 40(\% \mathrm{v} / \mathrm{v}) 50 \mathrm{~mL}$; Fraksi 6: Heksana:etil asetat $=50: 50(\% \mathrm{v} / \mathrm{v}) 50 \mathrm{~mL}$; Fraksi 7: Heksana:etil asetat $=40: 60(\% \mathrm{v} / \mathrm{v}) 50 \mathrm{~mL}$; Fraksi 8: Heksana:etil asetat $=30: 70(\% \mathrm{v} / \mathrm{v}) 50$ $\mathrm{mL}$; Fraksi 9: Heksana:etil asetat $=20: 80(\% \mathrm{v} / \mathrm{v}) \quad 50 \mathrm{~mL}$; Fraksi 10:Heksana:etil asetat $=10: 90(\% \mathrm{v} / \mathrm{v}) 50 \mathrm{~mL}$; Fraksi 11:Etil asetat $100 \%$ $50 \mathrm{~mL}$; Fraksi 12:Kloroform:Metanol = 50:50 (\% v/v) $50 \mathrm{~mL}$; dan Fraksi 13:Metanol 100\% $150 \mathrm{~mL}$

Fraksi sejumlah 13 macam, merupakan fraksi hasil pemisahan tersebut dianalisis menggunakan KLT dengan fase diam silika gel F254 dan fase gerak heksan:etil asetat (1:2.v/v). Profil KLT tiap-tiap fraksi terlihat pada Gambar 5.4., berikut:
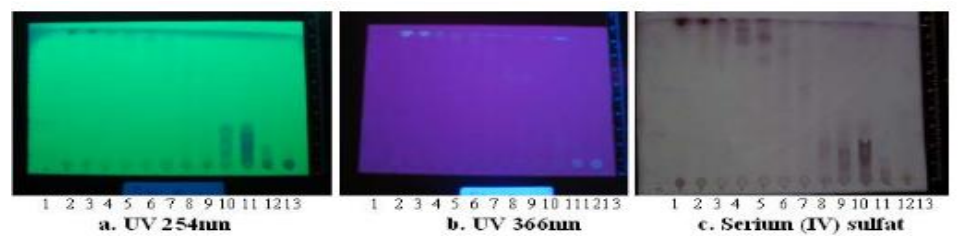

Gambar 5.4. Profil fraksi-fraksi hasil KLT ekstrak spons Kaliapsis

Gambaran bercak pada KLT terlihat adanya distribusi pemisahan bercak ekstrak kloroform ke dalam fraksi-fraksi. Analisis KLT menunjukkan kesamaan profil pada fraksi 1-9, kesamaan profil pada fraksi 10-11 dan kesamaan profil pada fraksi 12-13. Terhadap fraksi-fraksi dengan profil KLT mirip digabungkan dan dikeringkan untuk selanjutnya fraksi 1-9 disebut Gf I, fraksi 10-11 disebut Gf II sedangkan fraksi 12-13 disebut Gf III. Pada gabungan fraksi tersebut perlu dilakukan uji sitotoksik Karakteristik Lingkungan, Ekstraksi dan Daya Hambat Mikrosimbion [107] 
untuk melihat keaktifan dari masing- masing gabungan fraksi tersebut. Dari Tabel berikut dapat diketahui bahwa fraksi Gf II memberikan hasil uji yang ber- potensi untuk diisolasi senyawa aktifnya karena memberikan harga IC50 sebesar $8,5 \mu \mathrm{g} / \mathrm{mL}$.

Tabel 5.7. Sitotoksik Gabungan Fraksi I, II, dan III Ekstrak Kloroform Spons Kaliapsis sp, terhadap sel myeloma

\begin{tabular}{clc}
\hline No & Nama fraksi & Nilai IC $_{50}(\mu \mathrm{g} / \mathrm{mL})$ \\
1 & Gf I & 158,2 \\
2 & Gf II & 8,5 \\
3 & Gf III & 29,8 \\
\hline
\end{tabular}

Kromatografi preparatif fraksi Gf. II. Pemurnian terhadap gabungan fraksi II dengan KLT preparatif dilakukan melakukan pelarutan endapan Gf. II dengan kloroform kemudian ditotolkan pada silika gel F254 dengan. Pada Tabel 2, tersebut dapat diketahui bahwa fraksi Gf. II memberikan hasil uji berpotensi untuk diisolasi senyawa aktifnya, karena memberikan harga IC50 sebesar 8,5 $\mu \mathrm{g} / \mathrm{mL}$. Kromatografi preparatif fraksi Gf. II Pemurnian terhadap gabungan fraksi II dengan KLT preparatif dilakukan melakukan pelarutan endapan Gf. II dengan kloroform kemudian ditotolkan menggunakan jarum totol pada silika gel F254 dengan campuran fase gerak heksan:etil asetat (1:2 v/v). Ekstrak ini perlu dilakukan pengujian untuk melihat aktifitasnya melalui uji:

\section{a. Uji kemurnian Senyawa 1, 2 dan 3}

Sebelum dilakukan analisis berikutnya perlu pengecekan terhadap kemurnian senyawa 1,2 dan 3. Analisis kemurnian dilakukan dengan KLT dengan berbagai fase gerak menurut tingkat kepolaran yaitu heksan etil asetat $(1: 2 \mathrm{v} / \mathrm{v})$ dan heksan etil asetat $(1: 5 \mathrm{v} / \mathrm{v})$. Hasil uji kemurnian menunjukkan bahwa bercak 1, 2 dan 3 adalah murni secara KLT. Bercak 1 , untuk fase gerak yang semakin polar memberikan bercak dengan harga hRf yang semakin besar pula. Fase gerak (b) mempunyai harga hRf1 = 32 sedangkan fase gerak (a) hRf1 $=20$. Data tersebut dapat dikatakan bahwa bercak yang terdeteksi relatif murni. Hal ini juga berlaku pula untuk bercak 2, (b) hRf2 $=32$ dan (a) hRf2 $=36$. Bercak 3 (b) hRf3= 54 dan (a) $\operatorname{hRf} 3=60$. 


\section{b. Uji sitotoksik bercak 1, 2, 3 dan T}

Terhadap masing-masing bercak dilakukan uji sitotoksik menggunakan MTT. Dengan menggunakan pelarut DMSO (Tabel 5.8). Dari Tabel III. terlihat bercak 1 bersifat paling sitotoksik bila dibandingkan dengan bercak lain yaitu mampu menghambat/ mematikan sel myeloma pada IC50 sebesar $0,18 \mu \mathrm{g} / \mathrm{mL}$, sehingga bercak 1 perlu dilakukan analisis berikutnya. Spons Kaliapsis merupakan spons bangsa Lithistid. Spons bangsa Lithistid merupakan bangsa spons yang paling unik karena mengandung begitu banyak golongan senyawa.

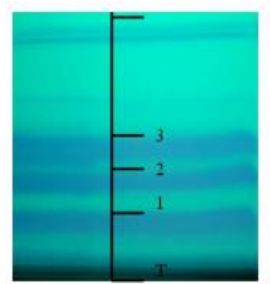

(a)

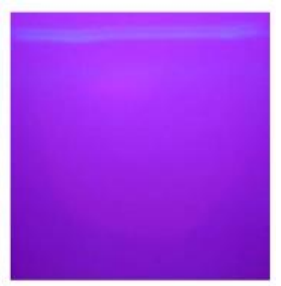

(b)

Gambar 5.5. KLT Prefaratif Gf. II dengan fase gerak heksana: etil asetat 1:2 v/v, dideteksi dengan UV $254 \mathrm{~nm}$

Gambar 5.5. Memperlihatkan hasil KLT Prefaratif Gf. II dengan menggunakan fase gerak heksana: etil asetat perbandingan 1:2 w/v, yang warna yang ada diamati menggunakan lampu UV pada $\lambda$ : $254 \mathrm{~nm}$. Hasil pengamatan menunjukkan adanya pemisahan bercak, dimana bercak yang ada biasanya identic dengan satu jenis komponen aktif.

Tabel 5. 8. Harga hRf bercak-bercak Gf. II

\begin{tabular}{ccccc}
\hline \multirow{2}{*}{ Namabercak } & \multirow{2}{*}{ Harga hR $_{\mathrm{f}}$} & \multicolumn{3}{c}{ Warna bercak } \\
\cline { 3 - 5 } & & UV 254nm & UV 366nm & Serium(IV)sulfat \\
\hline $\mathrm{T}$ & $\mathrm{hR}_{\mathrm{fl}}=3$ & Pemadaman & - & Coklat \\
1. & $\mathrm{hR}_{\mathrm{fl}}=33$ & Pemadaman & - & Coklat \\
2. & $\mathrm{hR}_{\mathrm{f} 2}=42$ & Pemadaman & - & Coklat \\
3. & $\mathrm{hR}_{\mathrm{f} 3}=50$ & Pemadaman & - & Coklat \\
\hline
\end{tabular}

Tabel 5.8, menunjukkan adanya pemisahan bercak-bercak dengan nilai masing-masing yang menampakkan warna coklat. Untuk meastikan bercak tersebut, maka dilakukan dengan pemurnian bercak, seperti yang ditunjukkan pada Gambar 5.6, berikut: 


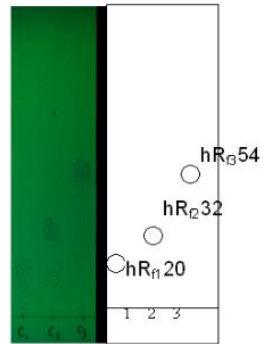

(a)

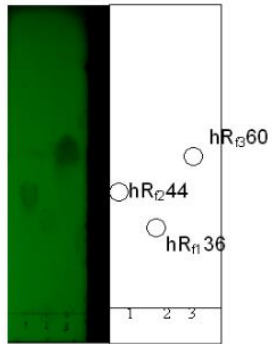

(b)

Gambar 5.6. KLT Uji kemurnian bercak 1,2 , dan 3

Uji kemurnian isolat aktif dilakukan dengan menggunakan KLT dengan berbagai variasi fase gerak. Senyawa dikatakan murni apabila memberikan peak tunggal pada KLT dengan berbagai fase gerak. Uji sitotoksik sel dilakukan dengan menggunakan MTT [3-(4,5-dimetiltiazol2-il)-2, 5- difeniltetrazolium bromida] pada plate 96 wheels terhadap biakan sel yang diberi perlakuan dengan senyawa uji pada berbagai kadar. Sel dengan kepadatan 2x104 sel/sumuran. Absorbansi dibaca dengan ELISA reader pada panjang gelombang 550nm. Hasil pengukuran serapan digunakan untuk menghitung $\%$ hidup dengan rumus:

\section{$\%$ hidup $=\underline{\mathrm{Abs}(\text { sel perlakuan-Kmedia) }} \times 100 \%$ Abs(Ksel-kmedia)}

Selanjutnya, dilakukan penghitungan \% kematian dan penghitungan IC50 dengan menggunakan analisis probit.

Spons Kaliapsis diekstraksi dengan metode maserasi menggunakan kloroform. Pada awal penyarian pelarut berwarna hijau tua. Penyarian dihentikan setelah ekstrak kloroform berwarna jernih yang berarti sebagian besar senyawa yang larut dakam kloroform sudah terekstrak. Dari total $2109.2 \mathrm{~g}$ berat basah spons diperoleh 6, $04 \mathrm{~g}$ ekstrak kering spons. Sisa spons kemudian dimaserasi lagi menggunakan pelarut metanol. Ekstrak metanol yang diperoleh sebanyak 8, 9 g ekstrak kering. Ekstrak etanol hasil maserasi spons dilakukan preparasi dengan penyaringan dan perendaman pada suhu $4 .{ }^{\circ} \mathrm{C}$ selama $24 \mathrm{jam}$. Hal ini dilakukan untuk menghilangkan garam-garam yang terlarut. Setelah diupkan filtrat kental yang diperoleh dipartisi dengan kloroform. Filtrat kloroform diuapkan dan diperoleh 3,76 g ekstrak kering kloroform. 
Pemeriksaan kandungan ekstrak kloroform spons dan ekstrak kloroform dari perendaman etanol dengan KLT menunjukkan profil kromatogram yang relatif sama sehingga kedua ekstrak ini dapat digabung. Berat gabungan kedua ekstrak adalah 9,8 g ekstrak kering atau rendemen total ekstrak sebesar $0,47 \%$ b/b spons basah

Uji pendahuluan sitotoksisitas untuk mendapatkan senyawa aktif perlu dilakukan uji terhadap ekstrak kloroform dan metanol. Dari Tabel 1 terlihat toksisitas ekstrak kloroform terhadap sel myeloma jauh lebih besar bila dibandingkan dengan ekstrak metanol sehingga untuk penelitian selanjutnya digunakan ekstrak kloroform.

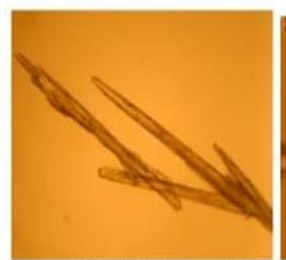

Kristal bercak 1

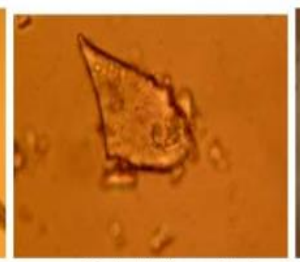

Kristal bercak 2

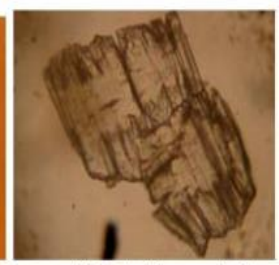

Kristal bercak 3

Gambar 5.7. Profil bercak 1, 2 dan 3

Fraksinasi ekstrak kloroform dan uji aktifitas fraksi-fraksi Ekstrak kloroform dipartisi menjadi beberapa fraksi dengan metode kromatografi kolom hampa udara dengan sistem fase gerak bertingkat. Kromatografi kolom hampa udara atau kromatografi kolom cepat merupakan metode pemisahan yang cepat dan mudah dari suatu ekstrak. Penyarian dilakukan atas dasar perbedaan tingkat polaritas. Pemilihan fase gerak didasarkan atas profil KLT.

Tabel 5.9. Efek Sitotoksik Bercak 1, 2, 3 dan T dari fraksi Gf. II Spons Kaliapsis sp, terhadap sel myeloma

\begin{tabular}{|c|c|}
\hline Nama bercak & Nilai IC $_{50}(\mu \mathrm{g} / \mathrm{mL})$ \\
\hline $\mathrm{T}$ & 10,5 \\
\hline 1 & 0,18 \\
\hline 2 & 15,35 \\
\hline 3 & 34,03 \\
\hline
\end{tabular}

Analisis KLT terhadap ekstrak kloroform menunjukkan pemisahan yang cukup bagus menggunakan fase gerak heksana:etil asetat $(5: 1 \mathrm{v} / \mathrm{v})$. Spons dari bangsa ini terkenal diantara jenis hewan tak bertulang belakang laut lain karena kemampuannya memproduksi beragam

Karakteristik Lingkungan, Ekstraksi dan Daya Hambat Mikrosimbion [111] 
metabolit aktif, seperti senyawa aktif dari golongan poliketida, peptid siklik, alkaloid dan sterol. Spons jenis ini juga menghasilkan beragam senyawa sitotoksik. Contoh spons jenis ini adalah dari suku Theonellidae marga Discodermia yang menghasilkan discodermolide suatu senyawa beraktifitas antikanker dan immunosuppressant yang telah memasuki fase praklinik didalam pengujiannya. Hasil uji sitotoksik terhadap sel myeloma menunjukkan bahwa ekstrak kloroform spons Kaliapsis sp, lebih aktif dibanding ekstrak metanol. Gabungan fraksi II ekstrak kloroform spons Kaliapsis sp, diperoleh bercak-bercak yang potensial sebagai senyawa sitotoksik dengan aktivitas tertinggi pada bercak 1 dengan harga IC50 sebesar $0,18 \mu \mathrm{g} / \mathrm{mL}$. 


\section{Bab -6-}

\section{POTENSI APLIKASI SPONS DAN MIKROSIMBION}

\section{1. Senyawa Bioaktif Spons dan Potensi Pengembangannya}

Spons adalah hewan unik yang dapat memproduksi senyawa bahan alam seperti terpenoid, alkaloid dan steroid yang bersifat antibakteri. Senyawa-senyawa tersebut memiliki potensi biomedik yang berguna bagi penyembuhan penyakit tertentu pada manusia, misalnya sebagai antibiotik, antitumor, antiinflamasi, inhibitor enzim, dan sifat-sifat lainnya. Spons juga diduga mengandung senyawa seperti saponin, asam fenolik, glikosida, peptide, amina dan turunannya, serta squalen termasuk turunannya yang dihasilkan dari metabolit sekunder. Selain senyawa tersebut, spons juga kaya akan senyawa kimia seperti asam amino, asam lemak, keratin, sterol, brominat phenol, dan turunan senyawa dibromotyrosine dan bromopyrol. Telah dilaporkan bahwa spons yang berhasil diekstraksi komponen bioaktifnya, ternyata teridentifikasi mengandung sterol dan turunannya, seperti poriferasterol, chondrillasterol dan elinasterol.

Kajian potensi spons, teridentifikasi tiga kemanfaatan, yakni: pertama, biomassa spons potensial untuk mereduksi sifat toksik beberapa jenis hidrokarbon dan sebagai media tumbuhnya mikroorganisme tertentu yang memiliki aktifitas anti bakteri; kedua, spons mengandung komponen metabolik primer dan sekunder yang berpotensi mengandung zat aktif komponen kimia tertentu potensial sebagai bahan baku obat dan kosmetik, dan; ketiga, spons dapat bersimbion dengan beberap jenis mikroorganisme potensial sebagai bakteri pendegradasi zat karsinogenik dan mutagenik limbah aromatik hidrokarbon dan juga sebagai bioabsorben beberapa jenis logam berat dalam limbah, bahkan dapat dikembangkan lebih lanjut untuk membuat formulasi bakteri karbonoklastik-loganoklastik sebagai biomaterial dan zat aditif pada beton. Studi tentang spons tidak banyak diungkap oleh para periset dunia, karena ketiadaan bahan spons untuk diteliti, sedangkan di Indonesia terdapat puluhan ribu jenis spons namun, disayangkan karena eksplorasi spons baru pada tahap identifikasi dan karakterisasi untuk beberapa jenis. 
Eksplorasi kemanfaatan spons sebagai kekayaan alam laut Indonesia harus dilakukan secara luas, konfrehensif dan terstruktur oleh para saintis Indonesia, dapat dilakukan dengan berkolaborasi dengan beberapa pihak yang memiliki kompetensi, kapasitas, sarana, prasarana dan kemampuan, termasuk pada industri agar diperoleh hasil signifikan. Studi tentang zat aktif spons memberi dampak positif pada tiga aspek pembangunan, yakni: penganekaragaman fungsi kekayaan sumber daya alam laut khususnya spons yang merupakan fokus kemaritiman; penanggulangan limbah hidrokarbon (PAH), penyelamatan sekaligus pembangunan lingkungan hijau, termasuk potensi spons dan mikrosimbion mengproduksi emzim yang dapat bertindak sebagai material dalam absorpsi logam berat.

Senyawa bioaktif diartikan sebagai senyawa kimia bahan alam yang mempunyai aktivitas biologi yang dapat dimanfaatkan. Senyawa bioaktif diperkirakan terdapat di alam dalam jumlah yang sangat besar dan tidak terbatas yang sampai saat ini penelusuran dan pencarian masih terus dilakukan. Senyawa bioaktif yang berhasil diisolasi terutama senyawa yang mempunyai aktivitas yang berguna dan sangat potensial untuk dikembangkan. Banyak senyawa bahan alam yang bersifat bioaktif berhasil diisolasi baik dari hewan maupun tumbuhan yang sangat berguna misalnya sebagai insektisida, pestisida, antifungi dan sitotoksik. Senyawa ini bahkan telah banyak disintesis pada skala industri dalam bidang pertanian dan obat-obatan. Pemisahan berbagai komponen kimia yang ada dalam ekstrak hewan dapat dilakukan dengan metode isolasi. Pemisahan ini didasarkan atas sifat adsorpsi dan partisi dari setiap komponen tertentu. Metode isolasi yang dilakukan dan telah banyak dikembangkan terdiri atas empat tahap yaitu dimulai dari pemilihan sumber organisme, ekstraksi senyawa bioaktif, fraksinasi senyawa bioaktif, dan uji bioaktifitas senyawa metabolit sekunder.

Porifera atau lebih dikenal dengan sebutan spons memiliki potensi yang bermanfaat bagi kehidupan dari kandungan kimia yang dimiliki oleh tubuhnya. Beberapa bahan kimia ini telah ditemukan memiliki efek farmasi bermanfaat bagi manusia, termasuk senyawa untuk obat pernapasan, kardiovaskular, gastrointestinal, anti inflamasi, antitumor, dan antibiotik. Setiap jenis porifera juga tersusun oleh kandungan kimia yang berbeda. Misalnya Porifera kapur, Porifera jenis ini kerangka 
tubuhnya terbuat dari bahan kristal zat kapur atau $\mathrm{CaCO}_{3}$ dan Porifera silikat, Porifera jenis ini kerangka tubuhnya terbuat dari bahan kristal silikat $\mathrm{H}_{2} \mathrm{Si}_{3} \mathrm{O}_{7}$, kristal-kristal yang berbentuk seperti duri, bintang, mata kail, jangkar dan lain-lain yang biasa disebut specula itu merupakan hasil bentukan atau sekresi dari sel-sel scleroblast.

Porifera (spons) menghasilkan metabolit primer dan metabolit sekunder sebagai hasil dari proses metabolisme. Pembentukan metabolit ini dipengaruhi oleh faktor lingkungan, dimana diasumsikan bahwa pada kondisi lingkungan yang berbeda, spesies yang sama belum tentu memiliki kandungan metabolit yang sama. Metabolit ini memiliki manfaat yaitu sebagai chemical defense untuk melindungi dirinya terhadap serangan lingkungannya, dengan kata lain untuk mempertahankan hidupnya dari serangan predator. Manfaat untuk manusia, sebagai substansi bioaktif untuk obat-obatan, makanan kesehatan dan kosmetik.

Pembentukan senyawa bioaktif pada spons sangat ditentukan oleh prekursor berupa enzim, nutrien serta hasil simbiosis dengan biota lain yang mengandung senyawa bioaktif seperti bakteri, kapang dan beberapa jenis dinoflagellata yang dapat memacu pembentukan senyawa bioaktif pada hewan tersebut. Senyawa terpenoid dan turunannya pada berbagai jenis invertebrata termasuk spons atau beberapa spesies dinoflagellata dan zooxanthelae yang memiliki senyawa-senyawa yang belum diketahui, yang kemudian diubah melalui biosintesis serta fotosintesis menghasilkan senyawa bioaktif yang spesifik pada hewan. Jenis senyawa bahan alam seperti terpenoid, kandungan senyawa bioaktif, seperti antibakteri, antitumor dan komponen senyawa kimia seperti asam amino, sterol phenol brominate sangat ditentukan oleh dinamika dan interaksi spons dengan lingkungan hidupnya, termasuk nutrian dan predator yang menjadi ancaman terhadap kehidupannya, sehingga spons tersebut akan terstimulasi untuk memproduksi zat spesifik tertentu sebagai prekursor yang merupakan upaya spons untuk dapat bertahan hidup pada lingkungan tertentu. Proses dan mekanisme ini yang menjadikan spons sebagai hewan unik yang juga dapat memproduksi senyawa spesifik yang dapat dimanfaatkan sebagai zat antibakteri, antifungi.

Zat lain yang dapat ditemukan pada spons adalah imunostimulan yaitu zat yang memiiki stimulin dan imunostin yang merupakan salah satu komponen ekosistem terumbu karang yang sangat potensial sebagai 
sumber bahan aktif. Hal ini dapat terjadi karena biosintesis senyawa aktif spons sangat dipengaruhi oleh perubahan bioekologinya sebagai respon pertahanan sistem metabolisme sel dari gangguan organisme lain disekitarnya. Sejauh ini, beragam hasil pengamatan ilmiah tentang spons yang telah dipublikasikan menunjukkan perolehan senyawa yang memiliki aktivitas biologik yang tinggi sebagai anti kanker, anti HIV, anti jamur, dan anti bakteri. Beberapa senyawa yang dihasilkan dari spons khususnya yang berada di perairan Indonesia antara lain adalah senyawa seskuiterpenoid tipe bis-abolen, (+)- curcuphenol (1) dan (+)-curcudiol (2) yang dihasilkan dari Axynissa sp memiliki aktivitas menghambat sintesa protein kinase pada pengujian antikanker secara in vitro. Senyawa Barrangamida suatu polipeptida siklik baru adalah senyawa aktif yang dihasilkan oleh spons Theonella swinhoei asal perairan Spermonde Sulawesi Selatan.

Aktivitas sitotoksik terhadap kanker serviks dari spons Aaptos suberitoides asal pantai Situbondo yang telah dilaporkan sangat dimungkinkan karena kemampuan spons sebagai rumah dan merupakan penampung bagi banyak jenis mikroba laut bahkan dapat mencapai $60 \%$ dari total biomassa spons. Mikroba simbion ini menghasilkan senyawa aktif sebagai respon terhadap kondisi ekstrim lingkungannya melalui mekanisme pertahanan tubuhnya. Spons dapat berasosiasi dengan sejumlah besar mikroorganisme berbeda seperti cyanobacteria dan alga uniseluler. Spons laut memiliki sumber yang kaya mikroorganisme baru dengan potensi aktivitas farmakologi. Interaksi antara spons dan bakteri terjadi dalam bentuk simbiosis komensalisme yang menghasilkan senyawa bioaktif. Metabolit mikroba yang berasosiasi dengan invertebrata laut memiliki kemiripan struktur dengan metabolit yang dihasilkan oleh inangnya. Beberapa aktivitas yang ditunjukkan oleh mikroba berasosiasi spons antara lain Microascus strain K 14 dan Monochaetia strain 193A20 yang berasosiasi dengan spons menunjukkan aktivitas antimikroba. Penicillium brocae berasosiasi spons zyzzya sp. menunjukkan aktivitas antimikroba terhadap bakteri Staphylococcus aureus resisten methicillin. Aktivitas sitotoksik ditunjukkan oleh fungi Gymnascela dan kaliensis berasosiasi dengan spons spons jenis Halichondria japonica. Penelitian imunostimulan dari beberapa biota laut seperti alga laut telah banyak dilaporkan. Aplikasi ekstrak rumput laut sebagai agen imunostimulan 
sistem pertahanan non spesifik pada udang yang telah dibukukan, meskipun sejauh ini, belum ada laporan tentang aktivitas imunostimulan dari metabolit protein pada spons dan mikroba simbionnya, namun kuat dugaan bahwa protein aktif seperti itu juga bisa dijumpai dalam spons. Agen imunostimulan yaitu bahan penguat sistem kekebalan tubuh yang sangat penting dalam usaha pencegahan penyakit infeksi seperti TBC. Berdasarkan temuan ilmiah dan observasi, diyakini bahwa spons dan mikrosimbionnya potensial menghasilkan produk protein yang dapat memperkuat daya tahan tubuh dari penyakit yang disebabkan oleh bakteri Mycobacterium tuberculosis.

\section{1. 1. Kandungan Alkaloid Spons}

Kandungan alkaloid pada spons ditemukan pada jenis spons Acanthostr ongylophora ingens merupakan famili petrosiidae diketahui mengandung alkaloid jenis manzamin. Data lainnya tentang kandungan metabolit sekunder telah diisolasi dari spons Acanthostrongylophora ingens. Spons ini diperoleh dari Makassar, tetapnya pada Pulau Lajukkang dan beberapa pulau sekitarnya yang merupakan gugusan Kepulauan Spermonde, Indonesia. Senyawa metabolic sekender dimaksud diantaranta manzamine A; 8-hydroxymanzamine A; manzamine F; dan 1deoxyircinol A (baru).

Senyawa baru alkaloid indole ditemukan pada spons spesies Petrosia (Petrosia) nigricans, diperoleh dari Pulau Barrang lompo, juga merupakan Gugusan Kepulauan Spermonde, SulawesiIndonesia, Alkaloid indole dimaksud, yaitu: Nigricinol [4-((1H-Indol-3yl)methyl)-2-amino-5-(1H-indol-3-yl)-3H-pyrrol-3-one]. Alkaloid jenis lain, yakni senyawa petrosin A dan petrosin B ditemukan pada spons Petrosia seriata. Dan Spons Petrosia similis dan senyawa xestospongin A diisolasi dari spons Xetospongia exigua, merupakan jenis spons yang diperoleh dari Australia. Senyawa turunan isoquinoline baru dari Petrosia spp, jenis spons termasuk Family Petrosiidae diperoleh dari Philipina.

\section{1. 2. Kandungan steroid, Turunan phenil dan Serebrosida}

Spon juga mengandung beberapa senyawa golongan steroid. Senyawa turunan steroid yang telah diisolasi dari spons Petrosia 
(Petrosia) nigricans, yaitu $24 \xi$-ethyl-cholesta-5-en-3 $\beta$-ol, $\quad \xi$-ethyl-

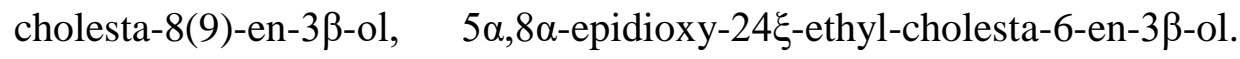
Lembehsterols A dan B adalah senyawa turunan steroid yang diisolasi dari spons Petrosia strongylata. Phenylacetic acid, p-hydroxyphenylacetic acid, phydroxyphenylacetic acid methyl ester, p-hydroxyphenylacetic acid ethyl ester, dan phydroxyphenylaceticacid butyl ester (baru), telah diisolasi dari Spons Petrosia (Petrosia) nigricans. Dua senyawa baru serebrosida yang diisolasi dari Petrosi (Petrosia) nigricans adalah petrocerebroside-1, petrocerebroside-2.

Spons laut memiliki potensi bioaktif yang sangat besar. Selama 50 tahun terakhir telah banyak kandungan bioaktif yang telah ditemukan. Kandungan bioaktif tersebut dikelompokan beberapa kelompok besar yaitu antiflammantory, antitumor, immunosuppessive, antivirus, antimalaria, antibiotik, dan antifouling. Spons merupakan biota laut potensial untuk menghasilkan senyawa bioaktif. Porifera mampu menyaring bakteri untuk dimanfaatkan sebagai makanan dan dicerna secara enzimatik. Senyawa bioaktif yang dimiliki oleh porifera kemungkinan bermanfaat dalam proses pencernaan, sehingga senyawa bioaktif yang diperoleh diperkirakan bervariasi sesuai dengan kebiasaan makan masing-masing jenis porifera.

Spon laut Acanthodendrilla sp. Tergolong dalam filum: porifera, kelas: demospongiae, ordo: dictyoceratida, family: irciniidae, genus: Acanthodendrilla. Kandungan kimia dari spon laut Acanthodendrilla sp adalah Acanthosterol, terdapat 10 derivat Acanthosterol yang merupakan steroid sulfat dan berkhasiat sebagai anti mikroba. Spons dapat memproduksi racun dan senyawa lain yang digunakan untuk mengusir predator, kompetisi dengan hewan sesil lain untuk berkomunikasi dan melidungi diri dari infeksi. Lebih dari 10 $\%$ spons memiliki aktifitas citotoksik yang dapat yang berpotensial untuk bahan obat-obatan.

Pada spons juga telah ditemukan berbagai senyawa yang dapat digunakan sebagai campuran obat seperti senyawa antitumor, antivirus, antibakteri, antijamur, antifouling, antimalaria dan lain-lain. Pada spons terdapat populasi mikroorganisme simbion. Simbion tersebut seperti archaea bakteria, sianobakteri, dan mikroalgae. Mikrooranisme tersebut merupakan sumber metabolit sekunder. Sebagai contoh, antibiotik Potensi Aplikasi Spons dan Mikrosimbion [118] 
polybrominated biphenyl ether yang diisolasi dari Dysidea herbacea sebenarnya dihasilkan oleh endosimbiotik sianobakterium. Fungi yang berasosiasi dengan spons diketahui pula menghasilkan senyawa bioaktif.

Pada beberapa jenis spons dari genus Aaptos mengandung metabolit sekunder dari golongan alkaloid yaitu aaptamine dan aaptosin pada fraksi methanol. Secara umum pada spons ditemukan kelompok senyawa pada fraksi non polar seperti senyawa terpenoid, senyawa steroid, dan asam lemak. Spons Aaptos Sp. Pada fraksi polar banyak mengandung senyawa alkaloid yang memiliki aktivitas antitumor, antimicrobial, antivirus, dan lain-lain. Spons dari jenis Heliclona Sp. Pada fraksi nHeksana banyak mengandung senyawa dari golongan steroid. Steroid dari sponge merupakan kelompok bahan senyawa bahan alam yang di biosintesis melalui jalur asam mevalonat sebagai hasil modifikasi senyawa triterpen.

\subsection{Enzim sebagai Komponen Unik Spons}

Enzim merupakan salah satu komponen unik spons. Kemampuan spons dalam menghasilkan berbagai jenis zat aktif, cara hidup spons dan mikrosimbion spons sebagai material pendegradasi hidrokarbon dan bioaprorpsi logam berat diduga karena peran zat yang dihasilkan oleh spons yang memiliki perilaku seperti enzim, meskipun hingga saat ini belum ada keterangan pasti terkait dengan kerja zat tersebut apakah enzim atau bukan. Metabolisme spons sangat unik dan menjadi bahan kajian yang mengundang banyak perhatian para penelitia untuk mengungkapnya. Molekul-molekul yang terkait dengan proses metabolism diantaranya Adenosin Trifosphat (ATP) adalah molekul yang disusun oleh adenin, ribose dan amina serta tiga molekul fosphatmerupakan molekul berenergi tinggi. Molekul ini merupakan ikatan adenosin yang mengikat tiga gugusan pospat, dengan ikatan yang lemah /labil sehingga mudah melepaskan ikatan pospatnya pada saat mengalami hidrolisis.

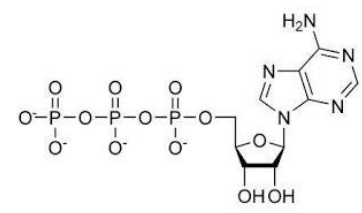

Gambar 6.1. Struktur molekul ATP 
Enzim merupakan senyawa organik jenis protein yang memiliki peran penting dalam metabolism makhluk hidup termasuk spons Senyawa dihasilkan oleh sel dan berperan sebagai katalisator (pemercepat suatu reaksi kimia) sehingga disebut Biokatalisator. Reaksi metabolisme dalam sel sangat membutuhkan keberadaan enzim. Enzim berperan sebagai pengatur kecepatan dan kekhususan ribuan reaksi kimia yang berlangsung di dalam sel. Walaupun enzim di buat di dalam sel, tetapi untuk bertindak sebagai katalis tidak harus selalu di dalam sel.

Komponen penyusun enzim berdasarkan senyawa pembentuknya yaitu protein enzim dibedakan atas 2 bagaian yaitu: a). Enzim sederhana yaitu enzim yang seluruh komponenenya terdiri atas protein; dan b) Enzim kompleks / Enzim konjugasi biasa juga disebut Haloenzim enzim yang komponen penyusunnya tidak hanya terdiri atas protein. Komponena apoenzim merupakan bagian dari enzin konjugasi yang berupa protein prostetik merupakan bagian dari protein konjugasi yang bukan senyawa protein. Komponen prostetik yang tersusun atas senyawa logam disebut kofaktor sedangkan gugus prostetik yang tersusun atas komponen organik seperti vitamin disebut ko-enzim.

Enzim terdiri atas beberapa macam, khususnya untuk enzim yang berperan dalam metabolism terdiri atas, 1) Oksido-reduktase yaitu enzim yang bekerja pada reaksi oksidasi dan reduksi; 2) Transferase bekerja untuk memindahkan gugus kimia; 3) Hidrolase bekerja mengubah bentuk kimia tanpa menambah atau mengurangi unsur; 4) Hidrolase bekerja pada reaksi yang menggunakan air; 5) Ligase bekerja pada reaksi penggabungan dua senyawa atau lebih dan 6) Liase bekerja pada reaksi pemutusan senyawa, sedangkan faktor yang mempengaruhi kerja enzim, diantaranya: 1) Suhu dengan peran yakni reaksi yang dikatalisis oleh enzim akan meningkat seiring dengan kenaikan suhu $0-35{ }^{\circ} \mathrm{C}$. Secara umum kenaikan $10^{\circ} \mathrm{C}$, maka kecepatan reaksi menjadi dua kali lipatnya dalam batas suhu yang wajar. Suhu ideal kerja enzim adalah $30-40{ }^{\circ} \mathrm{C}$; 2) Logam berat, seperti $\mathrm{Ag}, \mathrm{Zn}, \mathrm{Cu}, \mathrm{Pb}$ dan $\mathrm{Cd}$, menyebabkan enzim menjadi tidak aktif. Biasanya energy aktivitas enzim meningkat jika bereaksi dengan ion logam jenis $\mathrm{Mg}, \mathrm{Mn}, \mathrm{Ca}$, dan $\mathrm{Fe}$; 3) $\mathrm{pH}$, dimana umumnya enzim dapat bekerja dengan baik pada $\mathrm{pH}$ tertentu; 4) Konsentrasi memberi pengaruh kerja enzim; 5) Faktor dalam (faktor internal), seperti vitamin dan hormon berpengaruh terhadap aktivitas kerja 
enzim; 6) Keberadaan aktivator dan inhibitor mempermudah pembentukan ikatan enzim dengan substrat.

Salah satu jenis enzim yang telah diisolasi dari spons adalah enzim amilase. Aktivitas amilase diuji dengan menggunakan media Merine Agar (MA) yang ditambahkan amilum (1\%). Isolat kemudian digoreskan pada medium dengan metode gores. Lalu diinkubasi selama 1x24 jam. Jika pertumbuhannya bagus, diteteskan larutan Iodium pada permukaannya dan diamati zona bening di sekitar koloni biakan. Spesies spons yang diperoleh dari Pulau Barrang Lompo, setelah dianalisis morfologi diperoleh hasil ada 2 famili masing-masing terdiri atas 2 spesies Petrosia sp.

Contoh analisis makroskopik terhadap isolat bakteri spons Petrosia sp pada pengenceran $10^{-1}-10^{-6}$ yakni: berbentuk bulat permukaan rata, koloni terpisah-pisah dan menyebar keseluruh permukaan agar, berwarna putih dan coklat. Keterangan: Dari hasil isolasi pada pengenceran $10^{-1}$ sampai $10^{-6}$ kesemuanya mempunyai bentuk koloni dan warna koloni yang sama, sedangkan analisis mikroskopik untuk isolat yang sama untuk pengenceran $10^{-1}$, berbentuk batang dan spiral, berwarna merah koloni kecil dan besar, sedangkan pada pengenceran $10^{-2}$, berbentuk batang terpisah-pisah, berwarna merah, dan pada pengenceran $10^{-3}, 10^{-4}, 10^{-5}$, dan $10^{-6}$, masing-masing dengan pengamatan berbentuk batang dan berwarna merah, berbentuk batang panjang, berwarna merah dan bentuk serta warna pengamatan tidak beruh hingga pada pengenceran $10^{-6}$, hal ini menunjukkan bahwa isolat tersebut dalam bentuk tunggal. Pada pengujian enzim amilase bakteri simbion spons Petrosia sp, tampak terbentuknya zona bening sedang pada pengenceran 10-1; sedangkan zone bening sangat luas terjadi pada pengenceran $10^{-2}$, dan kemudian zone bening tersebut mengalami pengecilan pada pengenceran antara kisaran $10^{-4}$ hingga $10^{-7}$.

Pengamatan aktivitas enzim amilase pada medium, Merine Agar menunjukkan bahwa semua koloni pada sampel menunjukkan adanya aktivitas amilase. Isolat yang menghasilkan enzim amilase menghasilkan zona bening pada agar di sekitar koloninya jika ditetesi dengan larutan iodium. Dimana akivitas amilase sangat tinggi terjadi pada pengenceran $10^{-2}$ yang ditandai dengan adanya zona bening yang terbentuk sangat luas di sekitar koloni setelah penambahan larutan iodium. Hal tersebut 
menandakan bahwa amilum pada daerah tersebut telah terhidrolisis sempurna oleh enzim amilase. Sedangkan untuk pengenceran $10^{-4}, 10^{-5}$ dan pengenceran $10^{-7}$ zona bening setelah penambahan larutan iodium sedikit yang artinya daya ikat enzim amilase terhadap iodium juga kecil, hal ini terlihat pada medium yang masih berwarna biru kehitaman. Sedangkan untuk pengenceran $10^{-1}$ dan $10^{-3}$ aktivitas amilasenya cukup tinggi yang ditandai dengan adanya zona bening di sekitar koloni yang agak luas.

Adanya penambahan larutan iodium berfungsi untuk mengetahui kemampuan bakteri menggunakan pati. Degradasi yang terjadi pada pati diketahui dengan hilangnya material yang terwarnai oleh iodin. Kemampuan atau daya amilolitik suatu mikroba ditandainya dengan terbentuknya zona jernih dalam medium Merine Agar yang mengandung pati. Hal ini sesuai dengan literatur dimana setiap isolat murni yang dapat tumbuh diasumsikan dapat menggunakan media yang mengandung pati. Untuk memastikannya dilakukan uji iodin dengan cara meneteskan iodin pada permukaan agar yang berisi isolat, bila terdapat zona bening pada media mengindikasikan enzim amilase diproduksi oleh isolat sehingga di daerah tersebut amilum sudah dihidrolisis sedangkan media yang berwarna biru kehitaman menandakan pati di tempat itu belum terhidrolisis. Sebelum pengujian tiap isolat disiapkan stok kulturnya pada media miring.

\section{3. Zat Aktif Spons Sebagai Antioksidan}

Spons merupakan biota yang tidak memiliki alat gerak sebagai perlindungan diri, sebagai bentuk perlindungannya spons melakukan metabolit sekunder. Metabolit sekunder merupakan senyawa-senyawa hasil biosintetik turunan dari metabolit primer yang umumnya diproduksi oleh organisme yang berguna untuk pertahanan diri dari lingkungan maupun dari serangan organisme lain, sedangkan substansi yang dihasilkan oleh organisme melalui metabolisme dasar serta digunakan untuk pertumbuhan dan perkembangan organisme yang bersangkutan disebut dengan metabolit primer. Penarikan kandungan kimia bahan alam yang diisolasi dapat dilakukan dengan proses ekstraksi. Ekstraksi adalah proses pelarutan senyawa-senyawa kimia yang terdapat dalam suatu sampel dengan menggunakan pelarut yang sesuai dengan komponen yang 
diinginkan. Maserasi merupakan metode ekstraksi sederhana yang dilakukan dengan merendam serbuk atau simplisia dalam pelarut yang polar. Bisa juga dilakukan dengan menggunakan pelarut polar seperti metanol secara langsung dilakukan partisi dengan pelarut pada kepolaran yang terus ditingkatkan melalui proses ekstraksi.

Hingga saat ini, spons dikenal sebagai biota yang paling banyak menghasilkan senyawa bioaktif, seringkali dengan aktivitas bioaktif yang tinggi jika dibandingkan dengan biota laut lainnya, salah satu famili spons yang memiliki senyawa dengan bioaktivitas tinggi berasal dari Famili Callyspongiidae. Pada uraian ini, kami mengambil spons Callyspongia sp. yang merupakan salah satu genus spons yang banyak diteliti kandungan dan aktivitas senyawa bioaktifnya. Spons Callyspongia sp. merupakan salah satu jenis bunga karang yang paling banyak ditemukan di perairan Indonesia. Pada spons ini ditemukan kandungan beberapa senyawa metabolit sekunder seperti alkaloid 3-alkilpiridin, akartepin yang merupakan inhibitor dari fosfatidilinositol, meroterpenoid sulfat dan masih banyak lagi jenis senyawa bioaktif yang dapat ditemukan dalam spesies spons Callyspongia sp. Spons ini memiliki struktur permukaan tubuh yang berpori-pori sehingga ia dimasukkan kedalam filum porifera, Kebanyakan dari spesies spons hidup di air laut, dan tidak mempunyai jaringan atau organ yang sejati. Bentuk dan ukurannya sangat bervariasi. Pola pertumbuhan sangat dipengaruhi oleh keadaan substrat.

Temuan tentang senyawa bioaktif spons, mengingat pada pentingnya fungsi antioksidan bagi tubuh manusia, maka diperlukan suatu penelitian mengenai aktivitas antioksidan yang terdapat pada spons Callyspongia sp. Pada uraian sebelumnya diketahui bahwa spons Callyspongia sp. mempunyai aktivitas antioksidan karena spons ini banyak mengandung senyawa alkaloid yang memiliki aktivitas antioksidan. Akan tetapi pada uraian ini, diharapkan muncul wawasan dan pengetahuan serta informasi mengenai aktivitas antioksidan dari kelompok protein bioaktif dari Callyspongia sp. yang berasal dari pulau Barang Lompo bagian dari gugusan Kepulauan Spermonde, Sulawesi Selatan yang dapat digunakan sebagai zat antioksidan baru.

Metode isolasi protein yang merupakan bioaktif spons Callyspongia sp. dapat dilakukan dengan memotong kecil-kecil spons tersebut, lalu ditimbang kira-kira sebanyak $500 \mathrm{~g}$ berat segar, kemudian 
dihaluskan dengan blender menggunakan $500 \mathrm{~mL}$ pelarut buffer A, selanjutnya disaring dengan kain saring. Filtrat yang di peroleh dibekucairkan sebanyak 2-3 kali lalu disentrifugasi pada $6000 \mathrm{rpm} 4{ }^{\circ} \mathrm{C}$ selama 30 menit, selanjutnya supernatannya difraksinasi.

Pada proses fraksinasi ekstrak kasar sampel spons difrasinasi dengan menggunakan amonium sulfat pada tingkat kejenuhan masingmasing: 0-20\%, 20-40\%, 40-60\% dan 60-80\%, kemudian dilakukan sentrifugasi dengan kecepatan $10000 \mathrm{rpm}$ dengan suhu $4{ }^{\circ} \mathrm{C}$ selama 30 menit. Hal ini bertujuan untuk memisahkan jenis protein berdasarkan tingkat kelarutan dan jumlah gugus-gugus hidrofob yang terdapat pada asam-asam amino penyusun protein. Penambahan garam amonium sulfat pada konsentrasi rendah ke konsentrasi tinggi pada setiap tingkat fraksi, berbeda juga jenis protein yang mengendap karena molekul air yang berikatan dengan ion-ion garam semakin banyak sehingga terjadi penarikan selubung air yang mengelilingi permukaanHasil yang diperoleh dialysis, dimana endapan-endapan yang diperoleh setelah fraksinasi dari masing-masing tingkat kejenuhan amonium sulfat ditambahkan $5 \mathrm{~mL}$ buffer B kemudian didialisis dalam sejumlah buffer C. Masing-masing fraksi protein tersebut dimasukkan dalam kantong selofan dengan dipastikan bahwa kantong selofan itu tidak bocor atau rusak.

Selofan yang telah diisi dengan fraksi protein dimasukkan ke dalam gelas kimia yang berisi larutan buffer $\mathrm{C}$ lalu diaduk dengan pengaduk magnetic stirrer. Dialisis terus dilakukan sampai larutan buffer $\mathrm{C}$ tidak berwarna lagi. Langka selanjutnya adalah penentuan kadar protein dalam spons dilakukan dengan mengikuti metode metode Lowry dengan menggunakan bovine serum albumin (BSA) sebagai standar. Kedalam gelas kimia dimasukkan $4 \mathrm{~mL}$ larutan sampel ditambahkan 5,5 mL pereaksi Lowry B, dihomogenkan lalu dibiarkan selama 10-15 menit pada suhu kamar, selanjutnya ditambahkan $0,5 \mathrm{~mL}$ pereaksi Lowry A, dihomogenkan dan dibiarkan selama 30 menit. Diukur absorbannya pada $\lambda$ max. Penentuan kadar protein dilakukan dengan cara mensubtitusikan absorbansi larutan kedalam persamaan regresi kurva kalibrasi larutan standar protein. Langka berikutnya adalah Uji aktivitas antioksidan dengan metode DPPH (1,1-difenil-2-pikrilhidrazil) Fraksi protein 0-20\% kejenuhan dengan variasi konsentrasi $30 \mu \mathrm{g} / \mathrm{mL}, 35 \mu \mathrm{g} / \mathrm{mL}, 40 \mu \mathrm{g} / \mathrm{mL}, 45$ $\mu \mathrm{g} / \mathrm{mL}$ dan $50 \mu \mathrm{g} / \mathrm{mL}$, lalu masing-masing dimasukkan ke dalam Labu 
ukur $5 \mathrm{~mL}$, kemudian ditambahkan 0,5 mL larutan DPPH 0,1 mM. Volume dicukupkan sampai $5 \mathrm{~mL}$, kemudian diinkubasi pada suhu $37{ }^{\circ} \mathrm{C}$, selama 30 menit, selanjutnya serapannya diukur pada panjang gelombang maksimum. Perlakuan yang sama dilakukan pada masing-masing fraksi 20-40\%, 40-60\%, dan 60-80\%. Langka yang sama dilakukan juga pengukuran absorbansi blanko. Hasil penetapan antioksidan dibandingkan dengan vitamin $\mathrm{C}$ sebagai control positif. Besar daya antioksidan dihitung dengan rumus:

$\%$ Aktivitas Antioksidan $=\frac{\text { absorbansi kontrol-absorbansi sampel }}{\text { absorbansi kontrol }} \times 100 \%$

Uji aktivitas antioksidan menggunakan metode DPPH menunjukkan bahwa ekstrak Callyspongia sp.mempunyai IC50 sebesar 41,21 $\mu \mathrm{g} / \mathrm{ml}$. Hal ini menunjukkan bahwa ektrak tersebut mempunyai aktifitas aktioksidan yang kuat, karena mempunyai IC50 kurang dari $200 \mu \mathrm{g} / \mathrm{ml}$. Hasil ini apabila dibandingkan dengan aktivitas antioksidan vitamin $\mathrm{C}$ dan BHT yang masing-masing mempunyai nilai IC50 sebesar 3,45 dan 3,81 $\mathrm{mg} / \mathrm{ml}$, akti- vitas antioksidan ekstrak Callyspongia sp. masih lebih rendah. Tetapi pada penelitian ini yang diuji masih berupa ekstrak kasar, sehingga masih ada kemungkinan senyawa murni yang dikandung memiliki aktivitas peredaman radikal bebas lebih kuat dibandingkan ekstraknya. Metode DPPH dipilih karena sederhana, mudah, cepat dan peka serta hanya memerlukan sedikit sampel. Senyawa antioksidan dapat bereaksi dengan radikal DPPH melalui mekanisme donasi atom hydrogen dan menye- babkan terjadinya peluruhan warna

Perubahan warna DPPH dari ungu ke kuning yang diukur pada panjang gelombang $517 \mathrm{~nm}$ menunjukkan bahwa ekstrak memiliki aktivitas sebagai antioksidan Hasil uji aktivitas antioksidan ekstrak Callyspongia sp. menggunakan metode tiosianat menunjukkan tidak adanya perbedaan aktivitas yang bermakna (Anava searah dengan tingkat kepercayaan 95\%) dengan pembanding vitamin C dan BHT, seperti terlihat pada Gambar 1. Pada metode tiosianat pengukuran aktivitas antioksidan ber- dasarkan daya penghambatan terbentuknya senyawasenyawa radikal yang bersifat reaktif. Oksidasi asam linoleat dipercepat oleh AAPH yang merupakan senyawa penginduksi pembentukan radikal bebas, yang umumnya berupa peroksida lipid. Dekomposisi AAPH 
menghasilkan molekul nitrogen dan dua radikal karbon yang dapat menghasilkan produk yang stabil atau bereaksi dengan molekul oksigen meng- hasilkan radikal peroksil. Proses oksidasi lemak menghasilkan produk primer peroksida. Bilangan peroksida dinyatakan sebagai senyawa yang mampu mengoksidasi $\mathrm{Fe}^{2+}$ menjadi $\mathrm{Fe}^{3+}$, selanjutnya $\mathrm{Fe}^{3+}$ dengan ion CNS menghasilkan warna merah yang diukur pada panjang gelombang $500 \mathrm{~nm}$. Pada pengamatan yang dibandingkan dengan kontrol negatif menunjukkan serapan sebesar 0,415 sedangkan ekstrak Callyspongia sp mempunyai serapan 0,133 , vitamin C dan BHT masingmasing 0,132 dan 0,146. Hal ini berarti bahwa ekstrak Callyspongia sp. mampu menghambat hasil oksi- dasi asam linoleat maupun mereduksi radikal bebas.

Hasil uji statistik (anava searah dengan nilai $\alpha 0,05$ ) menunjukkan bahwa ketiga larutan yang diuji tidak memperlihatkan perbedaan aktivitas antioksidan yang bermakna. Hasil identifikasi kimia menun- jukkan bahwa ekstrak Callyspongia sp. mengandung senyawa alkaloid. Identifikasi lanjutan menggunakan KLT silica gel GF254 dengan larutan pengembang campuran methanol- $\mathrm{NH}_{4} \mathrm{OH}$ (200:3) memper-lihatkan adanya bercak dengan Rf 0 , 33, yang pada pengamatan sinar UV menghasilkan warna kuning hijau. Bercak ini memberikan warna jingga dengan pereaksi Dragendorff, berarti bahwa bercak tersebut merupakan senyawa golongan alkaloid. Pada uji dengan pereaksi DPPH, bercak ini mem- berikan aktivitas peredaman radikal bebas, berarti senyawa yang mempunyai aktivitas antioksidan dalam ekstrak Callyspongia sp. adalah senyawa golongan alkaloid. 


\section{Bab -7-}

\section{SEBARAN SPONS INDONESIA DAN ANCAMAN KEPUNAHAN}

\section{1. Spons pada Kepulauan Spermonde}

Gugusan Kepulauan Spermonde terbentang di antara perbatasan laut Pare-pare dan Barru kea rah Selatan hinggan masuk ke Kepulauan Selayar. Sulawesi Selatan memiliki 24 kabupaten dan kota dengan jumlah pulau sebanyak 309 tersebar di 13 kabupaten termasuk Kota Makassar, dan Palopo. Sebaran 309 pulau tersebut, 16 pulau yang tersebar pada sejumlah kabupaten yang tidak termasuk dalam gugusan Kepulauan Sepermode. Pulau-pulau tersebut adalah: Pulau Loeha, Onrongalang, Mori, Lanipanipa, Langkara, Saria Lampe, Caria, BulupoloE, Bete dan Balanbang (Luwu Timur), Bulubetta (Kab. Bone). Pulau Libukang (Palopo), Pulau Lawakeng, Lamarang dan Depo masuk dalam wilayah Kabupaten Pinrang.

Jumlah pulau yang masuk dalam kawasan Kepulauan Spermonde sebanyak 293, dengan sebarang terbanyak masuk dalam wilayah kerja Kepulauan Selayar dengan jumlah pulau sebanyak 126 pulau, beberapa diantaranya Pulau Tinanja, Tinabo Kidi, Tinabo Bakka, Tarupa Kidi, Tarupa Bakka, Tambuna Kidi, Tambuna Bakka, Rajuni Kidi, Rajuni Bakka, Pulopanjang, Pasitallu Tangnga, Pasitallu Raja, dan pulau lainnya. Banyaknya pulau yang terletak pada wilayah kerja Kabupaten Selayar, maka Selayar dijuluki sebagai daerah Kepulauan dengan julukan Kepulauan Selayar. Kabupaten Pangkajene dan Kepulauan dengan jumlah Pulau sebanyak 114 pulau. Jumlah pulau yang banyak ini menyebabkan Kabupaten Pangkajene juga dijuluki sebagai kabupaten kepulauan dengan julukan Pangkajene dan Kepulauan disingkat Pangkep. Pulau-pulau yang terletak di Kabupaten Pangkep diantaranya Pulau Bangkaulung, Butungbutungan, Dewokeng Caddi, Balabaloang Lompo, Balabaloang Caddi Manukang, Pammatauang, Tambakulu Sangi dan lainnya. Kabpaten dengan pulau terbanyak berikutnya adalah Sinjai dengan jumlah pulau sebanyak 14 buah, diantaranya Pulau Burungloe, Kanalodua, Kanalosatu, Liangliang, Lapoipoi, Kambuno Kodingareng dan bebebarapa lainnya. 
Makassar merupakan kota dengan jumlah pulau yang masuk dalam wilayah Kota Makassar sebanyak 12 buah, diantaranya Pulau Lumulumu, Lanjukang, Langkai, Kolokoloang, Kodingarengkeke, Kodingareng. Bonetambung, Barrang Lompo, Barrang Caddi, Samalona, Laelae, Kayangan. Berikutnya adalah Kabupaten Barru dengan jumlah pulau juga sebanyak 12, diantaranya Pulau Puteangin, Gusungbulobulo, Lawase, Kassipute, Batuloang, Batukalasi, Pannikiang dan lain sebagainya. Kabupaten Takalar dengan jumlah pulau sebanyak 9 buah diantaranya Pulau Tanakeke, Satangnga, Rewataya, Pokko, Latangkeo, Labbatallua dan beberapa pulau lainnya, sedangkan Kabupaten Bulukumba dengan 5 buah pulau diantaranya Pulau Samboang, Liukang, Bili, Batukasuso dan Batutaha dan Jeneponto sebanyak 1 pulau, yakni Pulau Harapan dan satu lagi pulau yang posisinya tidak termasuk dalam wilayah kerja kabupaten yang ada di Sulawesi Selatan yakni Pulau Betang.

Gugusan Kepulauan Spermonde dengan 293 pulau umumnya merupakan pulau yang didiami oleh spons dengan berbagai jenis yang hampir terwakili dari empat kelas spons yang dikenal selama ini. Pengkajian tentang keberadaan spons di Kepulauan Spermonde belum dilakukan secara maksimal. Pengkajian selama ini hanya sebatas pada identifikasi jenis spons dan sebarannya, sedangkan karakterisasi spons belum banyak dilakukan. Data yang ada jenis spons yang tersebar disepanjang Gugusan Kepulauan Spermonde tidak kurang dari 2.500 jenis, namun baru sebatas hasil identifikasi dan sebaran populasinya. Eksplorasi spons yang ada dalam kawasan Gugusan Kepulauan Spermonde baru sebatas pada tahap pemetaan identifikasi jenis dan sebaran, adapun karakterisasi dilakukan dalam skala kecil untuk kepentingan riset yang umumnya dilakukan oleh mahasiswa itupun baru pada tahap analisis morfologi, histologi, uji fenotip melalui penentuan gram bakteri simbion dan uji biokimia, sedangkan uji genotif juga sudah dilakukan khusus pada beberapa jenis spons dan simbionnya. Percobaan transplantasi spons juga telah tercetat pernah dilakukan untuk dua spesies yang berlokasi di Barru untuk kepentingan penelitian.

Pengembangan pulau-pulau di kawasan Gugusan Kepulauan Spermonde sebagai destinasi wisata, usaha dayving dan usaha penginapan 
sudah banyak dilakukan baik yang dikoordinir oleh pemerintah setempat maupun oleh pengusaha swasta lokal dan relatif telah dikelolah dengan cukup baik, namun baru menyentu pada aspek keindahan pantai dengan mengusung hastak misalnya sunset, pasir putih, panorama dasar laut, usaha memancing manis dan lainnya. Pengusung keindahan dan fanorama spons sebagai sebuah destinasi wisata belum terlihat secara nyata, hal ini menjadi positif karena setidaknya akan mempertahankan kelestarian spons untuk dapat hidup secara baik dihabitat alaminya, karena pemanfaatan berbagai kegiatan ekonomi di perairan Kepulauan Spermonde dapat mengancam kelestarian biota laut tanpa kecuali spons yang ada di dalamnya. Kerusakan ekosistem terumbu karang dan Padang lamun yang ditemukan pada beberapa lokasi di beberapa pulau yang masuk dalam wilayah administratif Kota Makassar sebagai salah satu bukti nyata ancaman terhadap kelestarian biota laut termasuk spons.

Kepulauan Spermonde (Spermonde shelf) terdapat di bagian selatan Selat Makassar, tepatnya di pesisir barat daya Pulau Sulawesi. Sebaran pulau karang yang terdapat di Kepulauan Spermonde terbentang dari utara ke selatan sej ajar pantai daratan Pulau Sulawesi. Kepulauan Spermonde dikenal oleh masyarakat pulau sebagai pulaupulau Sangkarang dan terdiri atas \pm 121 pulau, mulai dari Kabupaten Takalar di selatan hingga Mamuju di Sulawesi Barat. Pemetaan Kepulauan Spermonde menjadi empat zona, membentang dari utara ke selatan. Pembagian zona distribusi terumbu karang tersebut, seperti halnya penelitian ini, sering dijadikan dasar dalam penelitian yang berkaitan dengan terumbu karang di wilayah kepulauan tersebut. Zona pertama atau zona bagian dalam merupakan zona terdekat dari pantai daratan utama Pulau Sulawesi, dengan kedalaman laut rata-rata $10 \mathrm{~m}$ dan substrat dasar yang didominasi oleh pasir berlumpur. Zona kedua, berjarak kurang lebih $5 \mathrm{~km}$ dari daratan Sulawesi, mempunyai kedalaman laut rata-rata $30 \mathrm{~m}$ dan banyak dijumpai pulau karang. Zona ketiga dimulai pada jarak 12,5 km dari pantai Sulawesi dengan kedalaman laut antara $20-50 \mathrm{~m}$. Pada zona ini banyak dijumpai wilayah terumbu karang yang masih tenggelam, sedangkan Zona keempat atau zona 
terluar merupakan zona terumbu penghalang (barrier reef zone) dan berjarak $30 \mathrm{~km}$ dari daratan utama Sulawesi. Di sisi timur pulau-pulau karang ini kedalaman lautnya berkisar 40 - 50 m; sedangkan pada sisi barat dapat mencapai kedalaman lebih dari $100 \mathrm{~m}$.

Kepulauan Spermonde memiliki tingkat keragaman karang yang cukup tinggi karena terdapat 78 genera dan sub genera, dengan total spesies 262. Dilihat dari tingkat penyebaran karang, sekitar $80-87 \%$ terdapat di daerah terumbu terluar. Adanya pengurangan tingkat penutupan karang hidup dan keragaman jenis (diversity) sebanyak 20\% dalam kurun waktu 12 tahun menunjukkan bahwa gugusan Kepulauan Spermonde berada dalam keadaan yang kurang kondusif untuk perkembangan biota, terlebih pada saat ini dimana pada area tersebut terdapat pembangunan reklamasi CPI.

Penurunan tingkat penutupan karang hidup masih terus berlanjut hingga saat ini, karena eksploitasi sumberdaya yang tidak berkelanjutan. Secara keseluruhan kondisi terumbu karang pulau-pulau terpilih sudah masuk kategori jelek, walaupun dibeberapa titik pengamatan masih ada yang relatif baik. Kelimpahan dan keragaman ikan karang dan biota lain yang berasosiasi dengan terumbu karang tidak cukup untuk disimpulkan ada tidaknya perubahan, mengingat waktu penelitian yang terbatas. Namun demikian, seperti di P. Baddi ditemukan spesies yang jarang ditemukan di perairan pulau lainnya di Spermonde, seperti ikan giru Amphiprion peridarion, ikan pakol Canthidermis sp., serta ikan kepekepe dari jenis Chaetodon auriga dan C. melannotus

Pengamatan yang telah dilakukan untuk mengkaji aspek ekologi dan penatakelolaan pengembangan minawisata bahari di bebebrapa pulau yang termasuk kawasan Kepulauan Spermonde, yaitu Pulau Sapuli, P. Satando, P. Saugi, P. Cambang-cambang, P. Salemo, P. Sakoala, P. Sabangko, P. Sagara, P. Sabutung, dan Gusung Torajae, dimana penentuan lokasi ini berdasarkan hasil citra satelit dengan melihat parameterseperti; kualitas air terdiri dari Suhu, salinitas, $\mathrm{pH}$, kecerahan, kedalaman, kecepatan arus, dan substrat, DO, Fosfat dan nitrat. Kondisi penutupan karang menggunakan metode line intercept 
transect. Hubungan antara karakteristik lingkungan perairan dengan ekosistem menggunakan Correspondence Analysis.

Berdasarkan pengamatan yang diperoleh bahwa kondisi tutupan karang hidup dalam kategori rusak buruk hingga baik, kondisi kualitas air masih memungkinkan dilakukan untuk berbagai pemanfaatan, sedangkan hubungan karakteristik lingkungan peraira dengan kondisi terumbu karang ditemukan dua ciri kelompok, Luasan peruntukan minawisata bahari diperoleh luasan yaitu wisata pantai 29,39 ha, wisata bahari 742,47 ha, karamba jaring apung 2.438,27 ha, budidaya rumput 136,98 ha dan perikanan karang di bagian luar perairan P. Sapuli, dan Gusung Torajae. Secara umum hasil yang diperoleh dari 14 lokasi memperlihatkan hasil yang berbeda. Persentasi penutupan karang yang diperoleh lebih banyak dari hard coral yang didominasi oleh Acropora dan sedikit karang lunak yang merupakan acuan dalam menentukan kondisi terumbu karang di lokasi tersebut. Karang Acropora merupakan kelompok karang yang dominan pada suatau perairan. Kondisi tutupan karang hidup dalam kategori rusak buruk hingga baik di P. Sapuli, P. Sabutung, P. Satando, P. Camba-cambaya, P. Saugi dan Gusung Torajae dengan kisaran tutupan karang hidup 52-70 \%, karang mati (dead coral) 1-14 \%, karang mati yang ditumbuhi alga (dead coral alga) 1- $20 \%$, algae tidak ditemukan hingga $8 \%$, pecahan karang mati (rubble) $1-10 \%$, dan pasir (sand) 5-14 \%.
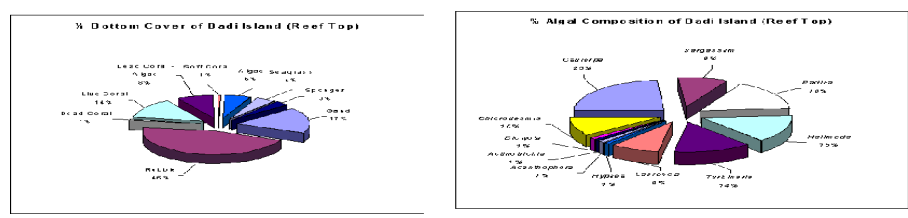

Gambar 7.1 Persentase Penutupan Dasar Perairan(a), \% Komposisi Alga (b), \% Komposisi Lamun
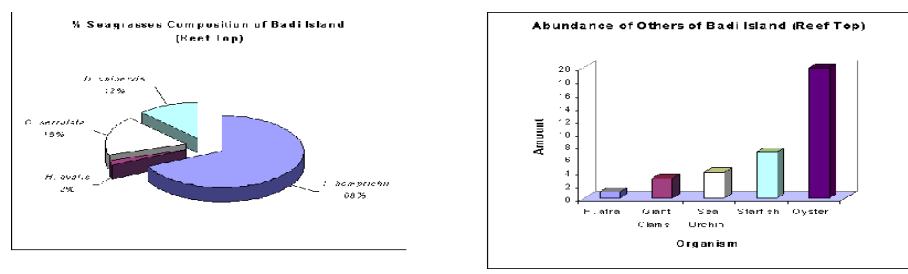

Gambar 7.1 . c) Kelimpahan Fauna Lainnya (d) di reef top Pulau Badi 
Berdasarkan Gambar 7.1 di atas, menunjukkan bahwa pengamatan terumbu karang menunjukkan bahwa pecahan karang (46\%) mendominasi reef top pulau, disusul pasir (17\%). Selain itu, terlihat tutupan karang mati sebesar $1 \%$; sedangkan karang mati yang telah ditutupi alga sebesar $8 \%$. Secara keseluruhan persentase karang hidup hanya $14 \%$, sehingga termasuk dalam kategori jelek. Dari keseluruhan persentase penutupan, terdapat karang lunak sebesar $1 \%$, spons $3 \%$, alga $6 \%$ serta vegetasi lamun sekitar $4 \%$.

Pada sisi Timur pulau ditemukan reef top dengan komposisi pasir, rubble dan karang hidup, vegetasi lamunnya sangat sedikit terdiri dari Thalassia dan Cymodocea. Di sisi ini terdapat satu titik yang tidak ditemukan lamun. Pada sebelah Selatan pulau ditemukan reef top yang cukup luas dengan komposisi substrat terdiri dari pasir, karang hidup dan rubble, dan tidak ditemukan lamun. Substrat umumnya tertutupi oleh karang hidup sampai pada areal reef edge. Di sisi Barat dan Utara terdapat reef top dengan komposisi pasir, rubble, karang hidup dengan komposisi lamun terdiri dari Thalassia, Halodule, Halophila dan Cymodocea.

Hasil analisis tersebut tidak jauh berbeda dengan hasil yang dilaporkan Coremap sekitar tahun 2006, di beberapa stasiun di P. Sapuli dan P satando dan P. camba-cambaya diperoleh penutupan karang hidup berkisar 60-70 \%, karang mati (dead coral) 5-15\%, pecahan karang mati (rubble) 5-10\%, dan pasir (sand) 5-15\%. Riset ini dilakukan sebelum ada kegiatan reklamasi kawasan Center Point of Indonesia (CPI).

\section{2. Sebaran Spons Indonesia}

Potensi spons Indonesia mencapai 80\% dari populasi dunia. Jumlah jenis spons diperkirakan mencapai 15.000 jenis, dan sekitar 3.500 diantaranya telah dikarakterisasi dari berbagai hasil riset. Eksplorasi dan eksploitasi spons masih terbatas pada identifiksi dan karakterisasi yang baru menyentuh pada beberapa spesies, meskipun penelitian tentang potensi spons untuk kepentingan medis berpotensi obat dan penanganan pencemaran lingkungan sudah dilakukan dalam skala kecil dan dilaksanakan secara terbatas dikalangan mahasiswa untuk kepentimgan 
tugas akhir dan diselenggarakan secara terpisah. Kajian teoritis potensi spons, teridentifikasi tiga kemanfaatan, yakni: pertama, biomassa spons potensial untuk mereduksi sifat toksik beberapa jenis hidrokarbon dan sebagai media tumbuhnya mikroorganisme tertentu yang memiliki aktifitas anti bakteri; kedua, spons mengandung komponen metabolik primer dan sekunder yang diperkirakan mengandung komponen kimia tertentu potensial sebagai bahan baku obat dan kosmetik, dan; ketiga, spons dapat bersimbion dengan beberap jenis mikroorganisme potensial sebagai bakteri pendegradasi zat karsinogenik limbah aromatik hidrokarbon dan juga sebagai bioabsorben beberapa jenis logam berat dalam limbah, bahkan dapat dikembangkan lebih lanjut untuk membuat formulasi bakteri karbonoklastik-bioabsorpsi sebagai biomaterial dan zat aditif pada beton.

Pengamatan tentang spons tidak banyak diungkap oleh para periset dunia, karena ketiadaan bahan spons untuk diteliti, sedangkan di Indonesia terdapat puluhan ribu jenis spons namun, disayangkan karena eksplorasi spons baru pada tahap identifikasi dan karakterisasi untuk beberapa jenis yang dilakukan secarab terbatas. Dengan demikian kemanfaatan spons untuk perikehidupan masa depan belum banyak memberikan hasil signifikan. Meskipun demikian eksplorasi kemanfaatan spons sebagai kekayaan alam laut Indonesia harus dilakukan secara luas, lengkap dan terstruktur oleh para saintis Indonesia. Usaha ini dapat dilakukan dengan berkolaborasi dengan beberapa pihak yang memiliki kompetensi, kapasitas, sarana, prasarana dan kemampuan, agar diperoleh hasil signifikan. Hal ini dilakukan mengingat bahwa potensi kemanfaatan spons dengan kandungan seperti biomassa, mikroorganisme simbion, zat aktif yang memiliki spons potensi sebagai bahan untuk fungsi degradasi komponen aromatik hidrokarbon dalam limbah toksik dan karsinogenik, bioabsorpben logam berat dan zat aktif dengan potensi untuk pengembangan dalam dunia kefarmasian memiliki masa depan yang sangat serah, sehingga dapat dikatakan bahwa pengembangan spons dapat menyentuh pada tiga aspek pembangunan, yakni: penganekaragaman fungsi kekayaan alam laut khususnya spons; penanggulangan limbah 
hidrokarbon (PAH), penyelamatan sekaligus pembangunan lingkungan hijau.

Secara umum spons dapat hidup pada lingkungan perairan yang dangkal sampai yang dalam, dengan salinitas sedang dan mendapat pencahayaan matahari yang cukup, termasuk adanya nutrisi yang dibutuhkan seperti planton dan fitoplanton yang didukung oleh arus laut yang sedang dan ombak yang landau, karena itu dapat dikatakan bahwa hampir sebagain besar kawasan pantai Indonesia cocok untuk kehidupan dan kelangsungan hidup spons. Keberadaan spons di Indoensia dimulai bagian barat Indonesia, yakni mulai dari pantai di Propinsi Aceh, Sumatera Selatan, Lampung, Bengkulu, sampai ke bagian tengah Indonesia yakni di sepanjang pantai Jawa Barat, Jakarta, terutama sesekitar Kepulauan Seribu, Jawa Tengan, dan Pantai di Surabaya menyebarang ke Bali, Nusa Tengara hingga sebagian kecil populasi spons di pantai Pulau Kalimantan hingga Sulawesi, dimana populasi spons tersebar disepanjang pantai Sulawesi Utara, Sulawesi Tenggara, Gorontalo, Sulawesi Barat dan Sulawesi Selatan dengan populasi terbanyak pada wilayah Kawasan Gugusan Kepulauan Spermonde. Populasi spons juga terdapat di Wilayah Maluku hingga ke Papua. Berikut ini adalah beberapa jenis spons yang ditemukan di Sulawesi Tenggara tepatnya di sekitar Konawe, seperti tampak pada Tabel 7.1, berikut:

Tabel 7.1. Beberapa Jenis Spons yang terdapat di Laut Konawe Sulawesi Tenggara

\begin{tabular}{|c|c|c|c|c|}
\hline \multirow{2}{*}{ No. } & \multirow{2}{*}{ Jenis Spons } & \multicolumn{3}{|c|}{ Indeks Keanekaragaman (H') } \\
\hline & & Stasiun I & Stasiun II & Stasiun III \\
\hline 1. & Stylotella sp. & 0,36 & 0,31 & 0,35 \\
\hline 2. & Xestospongia sp. & 0,29 & - & 0,15 \\
\hline 3. & Plakortis sp. & - & 0,33 & - \\
\hline 4. & Agelas sp. & 0,12 & - & - \\
\hline 5. & Callyspongia sp. & 0,20 & - & - \\
\hline 6. & Haliclona sp. & 0,20 & 0,18 & - \\
\hline 7. & Liosina sp. & 0,20 & - & - \\
\hline 8. & Petrosia sp. & 0,25 & - & 0,32 \\
\hline 9. & Ircinia sp. & - & 0,27 & - \\
\hline 10. & Lamellodysidea sp. & - & - & 0,15 \\
\hline 11. & Aaptos sp. & - & - & 0,15 \\
\hline 12. & Melophlus sp. & - & - & 0,36 \\
\hline & Jumlah & $1,64^{* *}$ & $1,11^{* *}$ & $1,51^{* *}$ \\
\hline
\end{tabular}


Berdasarkan jenis spons, family Halichondriidae dan jenis Stylotella sp. mempunyai kepadatan tertinggi pada daerah reef flat. Jumlah individu yang ditemukan di 3 titik Pantai Konawe sebesar 24 individu atau sebesar 0, 48 ind/10m2. Spons jenis ini memiliki bentuk lebih pendek. Kepadatan tertinggi spons pada daerah reef slope diperoleh dari family Petrosidae jenis Petrosia sp. Jumlah spons yang ditemukan berjumlah 7 individu $\left(0,14 \mathrm{ind} / 10 \mathrm{~m}^{2}\right)$. Jenis ini ditemukan pada 2 titik berbeda masih disekitar Pantai Konawe dengan ukuran bentuk lebih besar dan panjang. Perbedaan kepadatan spons dipengaruhi oleh beberapa faktor. Faktor kedalaman sangat mempengaruhi bentuk spons. Pada kedalaman 3m, bentuk spons cenderung pendek namun jumlah individu banyak sedangkan pada kedalaman $12 \mathrm{~m}$, ukurannya lebih panjang namun jumlah individu sedikit. Hal ini diduga karena pengaruh makanan (kelimpahan plankton), sinar matahari, dan kecepatan arus. Frekuensi kemunculan (FK) biota spons tertinggi didapat pada spons jenis Stylotella sp., dengan FK sebesar $100 \%$. Hal tersebut mengandung arti spons jenis ini terdapat di semua titik sebagian besar pantai. Kedalaman memberikan pengaruh yang nyata terhadap pertumbuhan suatu jenis spons.

Spons Stylotella aurantium dan kedalaman yang baik untuk pertumbuhan spons Stylotella aurantium adalah kedalaman 3m, lebih lanjut dapat dikatakan bahwa spons mengalami pertumbuhan yang baik dan hidup di perairan yang bersirkulasi baik, karenanya spons ditemukan pada perairan yang jernih bukan yang keruh. Arus air yang lewat melalui spons membawa serta zat buangan dari tubuh spons, maka penting bagi jenis spons, yakni air yang keluar melalui osculum dibuang jauh dari badannya karena air ini sudah tidak berisi makanan lagi, tetapi mengandung asam karbon dan sampah nitrogen yang beracun bagi hewan tersebut.

\section{3. Sebaran Spons Dunia}

Melakukan ekspedisi yang bertujuan untuk mengungkap rahasia terkait dengan hewan unik yang dinamakan spons yang dilakukan di Kepulauan Hawaii Barat Laut, peneliti dari National Oceanic Atmospheric Administration (NOAA) menemukan spons laut berukuran 3,5 meter di kedalaman 2.100 meter di bawah permukaan laut. Temuan ini Sebaran Spons Indonesia dan Ancaman Kepunahan [135] 
menginformasikan bahwa Spons laut mirip selimut yang terlipat ini diperkirakan menjadi spons laut terbesar dan tertua yang pernah ditemukan. Spons laut yang berasal dari famili Rossellidae ini berukuran panjang 3, 5 meter, tinggi dua meter dan lebar 1. 5 meter. Sebelumnya, spons laut terbesar yang ditemukan berada di laut Kanada dengan ukuran panjang 3,4 meter, tinggi 1,1 meter dan lebar 0,5 meter.

Spons laut lainnya yang ditemukan sebagai spons laut raksasa ini ditemukan di Papahānaumokuākea, sehingga diabadikan dengan membuat Marine National Monument. Spons laut juga diduga sebagai hewan tertua di bumi. Spons laut memang dipercaya sebagai hewan pertama yang berevolusi di bumi. Organisme yang hidup di laut dalam, megalami pertumbuhan sangat lambat, sehingga mereka membutuhkan habitat yang stabil dalam waktu lama agar bisa terus tumbuh menjadi lebih besar, meskipun sulit diyakini karena spons tidak memiliki lingkaran pertumbuahan tahunan untuk memperkirakan umurnya.

Beberapa spesies karang yang hidup dalam kedalaman itu bisa hidup selama ratusan atau bahkan ribuan tahun, dan yang paling tua berusia 4.500 tahun. Spesies raksasa lainnya juga merupakan jenis spons ditemukan di daerah perairan yang lebih dangkal yang masih merupakan daerah dari Papahānaumokuākea, diperkirakan sudah hidup selama 2.300 tahun. Papahānaumokuākea sendiri merupakan konservasi laut terbesar yang menjadi rumah bagi lebih dari 7.000 spesies. Wilayah ini menyaingi populasi spons yang ada di sekitar gugusan Kepulauan Spermonde Sulawesi Selatan, Indonesia. Di perairan lepas Northwestern Kepulauan Hawai juga ditemukan spons raksasa panjang 3, 5 meter yaitu spons yang diketahui terbesar di dunia dan bisa hidup ratusan atau ribuan tahun yang lalu. Spons laut Aphrocallistes vastus dengan ukuran hampir seukuran Kijang New Innova ditemukan di lautan pada kedalaman $4 \mathrm{~m}$ antara Hawaii dan Midway Atoll.

Pada areal lebih dari 140.000 mil persegi, Taman Laut Papahānaumokuākea adalah kawasan konservasi terbesar di Amerika Serikat dan lebih besar dari gabungan semua taman nasional lainnya di negara tersebut. Di kawasan konservasi barat laut Hawaii sebagian besar belum diselidiki. Karang di lingkungan yang identic, berumur 4.000 
tahun. Juga diketahui bahwa spons raksasa di perairan dangkal dapat berumur lebih dari 2.000 tahun. Sebagian besar perairan dalam di planet ini belum pernah dieksplorasi dan 7.000 spesies laut atau seperempat dari seluruh planet diketahui hidup di Taman Laut Papahānaumokuākea. Lumba-lumba menggunakan spons sebagai alat untuk membantu mengungkap makanan di dasar laut.

Spons dianggap beberapa hewan paling awal yang berevolusi di bumi, bahkan mungkin nenek moyang semua hewan kompleks. Mereka juga diduga membantu menganginkan laut purba, meningkatkan kehidupan di lautan sekitar 750 juta tahun lalu. Spons sering tumbuh bersama. Spesies membentuk habitat yang menyediakan tempat penampungan, penyaringan air laut dan menghapus materi kotor dalam air. Mereka sangat primitif, tidak memiliki sistem saraf atau pencernaan dan hanya mengandalkan aliran air melalui tubuh untuk mencari makanan dan sekaligus berlindung.

\section{4. Spons dalam Ancaman Kepunahan}

Sumber ancaman terhadap biota laut termasuk spons dapat diklasifikasikan dalam dua kelompok, yakni: pertama, disebabkan faktor dinamikan alam dan kedua, dinamika aktivitas manusia. Predator terhadap biota laut yang disebabkan oleh alam seperti letusan gunung merapi, dimana material-material yang disemburkan oleh letusan tersebut dapat masuk ke dalam area laut yang mungkin saja disekitarnya terdapat banyak populasi spons dan biota laut lainnya, mengakibatkan tertutupnya permukaan laut, sehingga pertumbuhan dan perkembangan spons dan biota lainnya terganggu bahkan dapat mengakibatkan kematian. Faktor alam lainnya adalah dinamika arus bawah laut, dimana fenomena ini dapat menyebabkan tersebarnya material-material laut yang pada akhirnya dapat mengakibatkan kekeruhan perairan. Efek dari kekeruhan perairan dapat berupa terhalangnnya sinar matahari untuk sampai ke dasar laut pada kedalaman tertentu, dimana sinar matahari sangat dibutuhkan oleh beberapa jenis biota laut termasuk spons. Kekeruhan karena gerakan partikel-partikel laut pada akhirnya dapat mengakibatkan terjadinya 
sedimentasi yang juga menimbulkan gangguan pada pertumbuhan dan perkembangan biota laut termasuk spons.

Ancaman kepunahan spons dan biota laut lainnya yang disebabkan oleh aktivitas manusia, juga dapat dibedakan atas dua jenis, yakni kecelakaan transfortasi laut. Kejadian ini merupakan insiden yang tidak disengaja namun menimbulkan masalah karena tercemarinya perairan laut oleh bahan tertentu yang bersifat racun terhadap biota laut. Kecelakaan kapal pengangkut bahan bakar minyak adalah salah satu jenis aktivitas manusia yang berakibat pada rusaknya kualitas perairan di lokasi tumpahan termasuk akan meracuni biota laut yang ada disekitarnya, sehingga pertumbuhan dan perkembangan spons dan biota lainnya akan rusak dan mungkin menimbulkan masalah yang lebih fatal seperti kematian biota laut secara massal dan jumlah yang sangat banyak. Masalaha lainnya yang mengancam kelangsungan hidup biota laut.

Masalah lainnya yang mengancam kehidupan spons dan biota laut lainnya yang disebabkan oleh aktifitas manusia seperti terjadinya pencemaran laut karena perilaku buruk masyarakat yang membuang sampah secara bebas di laut. Jenis sampah yang memberi dampak buruk pada kualitas perairan terutamah sampah plastik. Sampah plastik dapat melebar sehingga menempati permukaan yang laus. Semakin besar volume sampah plastik yang masuk ke dalam wilayah laut, semakin luas area tutup permukaan, terlebih lagi sampah plastik adalah jenis sampah yang tidak bisa terurai dalam waktu cepat. Kondisi ini menyebabkan terhalangnya sinar matahari untuk sampai kedasar laut pada suatu kedalam tertentu. Hal ini menyebabkan spons dan biota laut lainya mengalami gangguan pertumbuhan dan perkembangan, bahkan secama masif dapat menimbulkan biota laut mengalami kematian. Diketahui bahwa Negara kita Indonesia merupakan produsen plastik nomor tiga di dunia setelah China dan India, dimana plastik-plastik ini sebagai kemasan, lambat laun akan menjadi sampah, dan seiring dengan perjalanan waktu pada akhirnya sampah-sampah plastik ini akan bermuara ke laut. Kondisi ini perlu segera di antisifasi agar volume sampah yang masuk kelaut dapat diminimalkan.

Model penangkapan ikan dengan menggunakan bahan peledak dan racun ikan tertentu yang masih sering dipraktekkan oleh masyarakat 
nelayan kita, menjadi suatu ancaman tersendiri dan serius terhadap keselamatan populasi spons dan biota laut lainnya. Penggunaan bahan peledak seperti pothasium nitrat, selain menghasilkan tangkapan ikan yang tidak berkualitas juga menyebabkan kerusakan terumbu karang dan kematian biota laut yang tidak diinginkan. Perilaku nelayan Indoensia yang seringkali melakukan illegal fishing masih saja menjadi pilihan mudah untuk dilakukan, dimana sebaran nelayan yang banyak melakukan aktifitas penangkapan ikan masih sangat luas dan celakanya lagi area penangkapan ikan menggunakan bahan peledak dan racun ikan adalah area dimana terdapat banyak populasi spons dan biota lainnya. Penangkapan ikan dengan cara dibom atau penggunaan racun ikan dapat menyebabkan biota laut mati mendadak dengan jumlah populasi yang sangat besar, sementara pertumbuhan dan perkembangan biota laut terutama spons sangat lambat atau membutuhkan waktu yang sangat lama, bahkan terdapat jenis tertentu spons yang hanya mampu tumbuh $2-3 \mathrm{~cm}$ dalam setahun.

Pengembangan kawasan pantai untuk usaha ekonomi rakyat lainnya, seperti pendirian rumah-rumah terapung di laut, penggunaan area pantai dan pesisir untuk permukiman dan jasa penginapan hotel dan sejenisnya termasuk usaha lainnya dengan objek laut dan pesisir, seperti area permandian secara masif dapat menjadi masalah baru terhadap kelangsungan hidup biota laut. Izin aktivitas industri yang berlokasi di pinggir laut termasuk pendirian pabrik tertentu dengan model pabrik terapung bukan tidak mungkin dapat menimbulkan masalah baru yang berakibat pada terhambatnya pertumbuhan dan perkembangan biota laut.

Izin reklamasi pantai yang akhir-akhir ini banyak dilakukan oleh pemerintah baik pusat maupun daerah adalah jenis ancaman baru terhadap kelangsungan hidup biota laut. Reklamasi Teluk Jakarta, reklamasi pantai di Lampung, Bitung dan reklamasi CPI di Makassar berdampak signifikan pada berkurangnya garis pantai atau pantai diarea reklamasi menjadi dalam dan curam, sehingga keberadaan fitoplanton dan planton yang hanya cock pada laut dangkal menjadi hilang, sehingga siklus ekosistem juga mengalami perubahan dan terjadi ketidakseimbangan. Keadaan ini berdampak buruk pada kehidupan spons. Proses pembangunan 
(penimbunan) material lokasi reklamasi dipastikan menimbulkan kekeruhan perairan dalam waktu yang cukup lama sehingga jarak pandang terganggu, dan potensial untuk terjadi sedimentasi di laut dan pantai sekitarnya juga menjadi sekelumit permasalahan yang kerap kali harus di alami oleh biota laut. Semua faktor tersebut di atas adalah sejumlah penyebab kerusakan dan ancaman terhadap kepunahan spons dan biota laut lainnya.

Sejumlah permasalahan di atas merupakan ancaman terhadap kelangsungan hidup spons dan biota laut lainnya, sehingga diperlukan upaya-upaya konkrit sebagai bentuk pencegahan kepunahan terhadap biota laut, sekaligus langka pelestariannya, dapat berupa:

1 Memperbanyak kegiatan transplantasi spons baik jenis spons, volume transplantasi dan jumlah lokasi/ wilayah transplantasi

2 Perlunya konservasi kawasan pantai tertentu yang didalamnya terkumpul berbagai jenis biota laut dan populasi besar

3 Upaya perlindungan biota laut spesifik dan endemik yang didukung dengan regulasi

4 Diperlukan regulasi instansi pemerintah terkait dalam rangka perlingdungan biota laut;

5 Adanya zonasi wilayah pantai/laut yang kaya akan berbagai jeis biota khususnya spons.

6 


\section{Bab -8-}

\section{SPONS SEBAGAI OBJEK RISET MASA DEPAN}

\section{1. Karakterisasi Zat Aktif Spons}

Penelusuran atau dikenal dengan skrining material bioaktif dari organisme laut beberapa tahun terakhir, dilakukan sangat gencar sehingga mengalami perkembangan signifikan, baik yang lakukan di dalam negeri maupun diluar negeri. Substansi penting dari senyawa bioaktif, terutama terdapat pada biota laut yang tidak bertulang belakang (avertebrae) seperti spons, koral, moluska dan tunicate. Biota-biota tersebut mengandung senyawa aktif yang lebih banyak dan lebih pundamental dalam perkembangan kepentingan kemaslahantan orang banyak terutama pada aspek kesehatan jika komponen bioaktif yang teridentifikasi dari algae dan tumbuhan darat. Diantara biota laut tak bertulang belakang tersebut, spons menduduki tempat teratas sebagai sumber substansi aktif. Berbagai macam senyawa telah berhasil diisolasi dan dikarakterisasi dari biota ini diantaranya adalah alkaloid, terpenoid, acetogenin, senyawa nitrogen, halida siklik, peptide siklik dan lain-lain. Senyawa-senyawa ini merupakan golongan metabolisme sekunder dari biota spons. Hasil metabolisme sekunder ini mempunyai keaktifan sebagai antimikroba, antivirus, antikanker yang sangat berguna sebagai bahan baku obat. Metabolit sekunder adalah senyawa-senyawa hasil biosintetik turunan dari metabolit primer yang umumnya diproduksi oleh organisme yang berguna untuk imunitas dan kekebalan diri dari predator lingkungan maupun ancaman dari serangan organisme lain, berbeda dengan substansi yang dihasilkan oleh organisme melalui metabolisme primer, digunakan untuk pertumbuhan dan perkembangan organisme yang bersangkutan lebih dikenal dengan sebutan metabolik dasar.

Analisis metabolit sekunder dari spons merupakan produk alam yang sangat potensial sebagai bahan baku/primer obat. Perbedaan kondisi lingkungan seperti tingginya kekuatan ionik pada air laut, intensitas cahaya, pengaruh rendahnya temperatur, tekanan dan struktur tubuh yang berbeda, cara hidup, nutrisi dan dinamikan dalam pertumbuhan dan perkembangan biota seperti spons jika dibandingkan dengan organisme darat memungkinkan spons menghasilkan metabolit yang mempunyai 
struktur kimia yang spesifik dan bervariasi serta sangat mungkin memiliki fungsi yang signifikan terhadap kehidupan manusia. Kondisi ini memberi pengaruh kuat terhadap bioktivitas dari senyawa yang dihasilkan. Spons (porifera) merupakan biota laut multi sel yang fungsi jaringan dan organnya sangat sederhana.

Habitat spons umumnya adalah menempel pada pasir, batu-batuan dan karang-karang mati. Biota laut ini dikenal dengan "filter feeders", yaitu mencari makanan dengan mengisap dan menyaring air melalui sel cambuk dan memompakan air keluar melalui oskulum. Makanan spons berupa partikel-partikel makanan seperti bakteri, mikroalga dan detritus serta fitoplanton, subfitoplanton yang terbawa oleh aliran air. Habitat spons yang melekat pada pasir atau bebatuan menyebabkan hewan ini sulit untuk bergerak. Untuk mempertahankan diri dari serangan predator dan infeksi bakteri pathogen, spons mengembangkan system "biodefense" yaitu dengan menghasilkan zat racun dari dalam tubuhnya, zat ini umumnya dapat dimanfaatkan sebagai bahan farmasi. Zat tersebut berperilaku seperti enzim yang fungsi utamanya sebagai imunitas bagi spons, meskipun demikian zat yang diproduksi oleh spons tersebut akan berbeda-beda tergantung pada dinamika yang dialami oleh spons tersebut dalam pertumbuhan dan perkembangannya.

Hasil ekspedisi mengenai skrining spons, diketahui bahwa potensi spons Indonesia mencapai 830 jenis spons yang ditemukan di Indonesia Bagian Timur, sebagian besar ditemukan di Gugusan Kepulauan Spermonde yang membentang mulai dari perbatasan Pare-pare Barru kebagian utara Sulawesi Selatan hingga mesuk ke wilayah laut Kabupaten Selayar. Kekayaan jenis spons yang sangat potensial ini belum banyak dimanfaatkan oleh masyarakat Indonesia. Untuk memberi nilai tambah terhadap biota tersebut beberapa penelusuran telah dilakukan baik oleh institusi pemerintah maupun perguruan tinggi. Temua tersebut sebagai hasil dari pencarian bahan aktif dari hasil metabolisme sekunder dari biota-biota laut terutama spons. Tujuan lain dari penelusuran yang dilakukan baik dalam skema penelitian lembaga pemerintah, perguruan tinggi dan lembaga swasta adalah untuk mendapatkan sumber bahan baku obat-obatan dari biota laut termasuk spons. Perolehan metabolit sekunder dari biota laut khususnya spons dilakukan melalui metode isolasi, identifikasi dan karakterisasi dengan pengujian-pengujian spesifik dan 
umumnya dilanjutkan dengan metode pemisahan senyawa organik. Isolasi metabolit sekunder dari biota laut ini dilakukan dengan beberapa tahap, diantaranya ekstraksi senyawa menggunakan pelarut organik spesifik yang sesuai. Umumnya sampel biota laut (spons) dihaluskan dan dimaserasi (perendaman pada suhu rendah) atau dengan sokletasi (ekstraksi suhu tinggi). Pelarut organik yang biasa digunakan dalam isolasi biota laut umumnya yang bersifat polar seperti metanol, etanol dan etil asetat. Hal ini sangat berhubungan dengan sifat kepolaran senyawa yang diisolasi.

Struktur kimia beberapa senyawa aktif yang diisolasi dari biota ini mempunyai gugus polar, menyebabkan senyawa-senyawa yang terkandungan dalam tubuh biota tersebut larut dalam pelarut polar akibat pergerakan difusi oleh ketidakseimbangan konsentrasi antara komponen yang diekstraksi dengan larutan pengekstraknya. Selain itu, dengan menggunakan pelarut polar senyawa nonpolar dan polar yang terkandung dalam sampel ikut terlarut. Tahap kedua biasanya dilakukan dengan ekstraksi partisi pelarut. Ekstraksi partisi ini dimaksudkan untuk memisahkan senyawa-senyawa nonpolar dengan senyawa polar yang terdapat dalam ekstrak kasar.

Ekstraksi partisi dilakukan dengan mencampurkan dua pelarut yang tidak bercampur kedalam corong pisah. Ekstrak kasar akan terdistribusi kedalam dua pelarut sesuai dengan sifat kepolaran kompnen yang diekstraksi. Tahap selanjutnya adalah pemisahan senyawa organik menggunakan metode kromatografi. Metode kromatografi adalah pemisahan berdasarkan distribusi senyawa dalam fase gerak dan fase diam. Metode kromatografi yang umum dilakukan dalam pemisahan senyawa pada biota laut adalah kromatografi kolom, kromatografi lapis tipis dan kromatografi cair kinerja tinggi. Kromatografi kolom dilakukan dengan fase diam antara lain silika gel dan oktadesil silana dengan fase gerak bertingkat yang memiliki kepolaran juga bertingkat, mulai dari heksana, etil asetat, kloroform, diklorometan, methanol dan air. Tahap pemisahan sekaligus pemurnian senyawa dilakukan dengan kromatografi cair kinerja tinggi, kolom yang biasa digunakan untuk isolasi senyawa biota laut diantaranya adalah kolom ODS dan Mightysil. Pemisahan dengan kromatografi cair kinerja tinggi menghasilkan isolat-isolat 
senyawa tunggal, kemudian isolat ini diuji bioaktivitasnya dan diidentifikasi struktur kimianya.

Uji bioaktivitas antimikroba dan antijamur yang dilakukan biasanya dilaboratorium biokimia, laboratorium mikrobiologi, atau pada laboratorium yang spesifik seperti laboratorium produk alam laut menggunakan metode difusi agar, dengan bioindikator bakteri Staphylococcus aureus, Bacillus subtilis dan Vibrio eltor. Daya penghambatan ditunjukkan dengan melihat permukaan bening pada radius kertas cakram yang ditetesi sampel atau biasa disebut zoha hambat. Identifikasi struktur kimia senyawa aktif dilakukan dengan metode spektroskopi massa dan Nuklir Magnetik Resonansi (NMR). Spektroskopi massa dapat digunakan untuk menentukan bobot molekul dan massa fragmentasi ion molekulnya. Pada dekade terakhir ini penggunaan spektroskopi yang paling sering digunakan secara luas dan efektif adalah sepektroskopi 2D-NMR inti 13C dan $1 \mathrm{H}$, karena sangat efektif dalam penentuan struktur kimia komponen senyawa aktif dalam cuplikan. Hal ini karena prinsip dasar dari NMR adalah multidimensi dengan inti karbon dan proton yang ada sangat mempermudah dalam penentuan struktur kimia, karena mampu mendeteksi bentuk dan kerangka karbon berikut atom yang berikatan dengan inti karbon tersebut.

Beberapa isolat spons memiliki sifat sebagai anti bakteri, contohnya dapay kita lihat pada penggunaan isolat isolat bakteri Aplysina sp dan Sarcophyton sp terhadap bakteri E.coli, S.aureus, dan jamur C.albicans menunjukkan adanya sifat antibakteri dari ekstrak tersebut. Adanya antibakteri tersebut ditandai dengan adanya zona hambat disekitar paper dish yang telah diberi ekstrak antibakteri tersebut yang diujikan pada bakteri E. coli, S. aureus, dan jamur C. albicans.
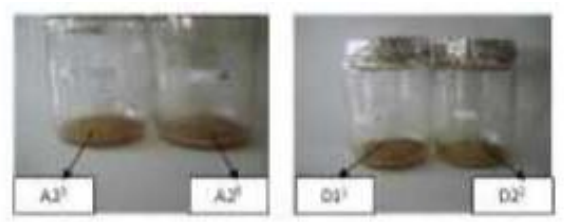

Gambar 8.1. Ekstrak isolat spons Aplysina sp dan Sarphyton sp dengan menggunakan pelarut methanol 


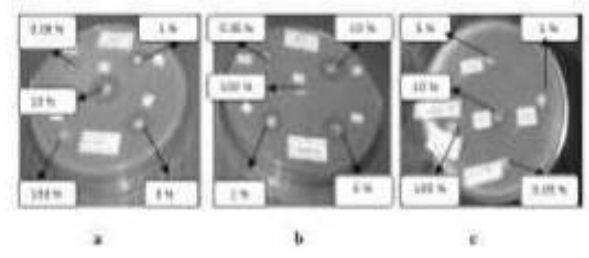

Gambar 8.2. Hasil uji KHM ekstrak Aplysina sp dan Sarphyton sp terhadap a) E. Coli; b) S. aureus dan c) c. albicans

Uji konsentrasi hambat minimum (KHM) ekstrak isolat Aplysina sp (A) dan Sarcophyton sp (B) terhadap bakteri E. coli , S. aureus dan jamur C. albicans. Hasil pengamatan pada ekstrak isolat bakteri (A) dan (S) menunjukkan konsentrasi hambat minimum pada konsentrasi terendah yaitu pada konsentrasi 0, $05 \%$ masih menunjukkan adanya aktivitas antibakteri. Hasil ekstrak isolat bakteri (A) dan (S) pada konsentrasi 0, $05 \%$ yang memiliki aktivitas antibakteri yang paling besar terdapat pada ekstrak isolat (S) terhadap S.aureus sebesar 11 $\pm 1,00 \mathrm{~mm}$ dan pada ekstrak isolat (A) terhadap E. coli sebesar 11,33 $\pm 2,31 \mathrm{~mm}$.

Aktivitas antibakteri terdapat pada konsentrasi $0.05 \%$ terhadap E. coli sebesar 11, 33 $\pm 2,31 \mathrm{~mm}$ dan terhadap S.aureus sebesar 9 $\pm 1,73 \mathrm{~mm}$. Nilai konsentrasi hambat minimum diketahui dengan melihat pada konsentrasi terendah masih menunjukkan adanya aktivitas antibakteri. Antibakteri dikatakan mempunyai aktivitas yang tinggi terhadap mikroba apabila nilai konsentrasi hambat minimumnya rendah tetapi mempunyai daya hambat yang besar. Suatu bahan dikatakan mempunyai aktivitas antibakteri apabila diameter hambat yang terbentuk lebih besar atau sama dengan 6. Kekuatan antibiotik ekstrak isolat (A) pada konsentrasi 0, $05 \%$ termasuk dalam kategori sedang untuk menghambat pertumbuhan bakteri. KHM pada konsentrasi $0,05 \%$ merupakan petunjuk konsentrasi antibakteri yang mampu menghambat pertumbuhan mikroorganisme dan juga memberi petunjuk mengenai dosis yang diperlukan dalam pengobatan penyakit yang disebabkan bakteri E.coli dan S.aureus. Konsentrasi hambat minimum ekstrak isolat (A) terhadap jamur C. albicans pada konsentrasi $(10,5,1$, dan 0, 05) \% tidak menunjukkan adanya aktivitas antijamur. 
Ekstrak isolat bakteri Aplysina sp (A) dan Sarcophyton sp (S) efektif menghambat pertumbuhan bakteri E.coli dan S.aureus karena memiliki daerah hambatan dalam kategori kuat (10-20 mm) dan sedang (5-10 mm) sesuai dengan ketentuan kekuatan antibiotik, tetapi tidak efektif menghambat pertumbuhan jamur C.albicans . Berdasarkan hasil pengamatan, KHM dari ekstrak isolat bakteri Aplysina sp (A) dan Sarcophyton sp (S) memiliki aktivitas antibakteri yang paling besar terdapat pada konsentrasi $10 \%$ ekstrak isolat (A) terhadap S.aureus sebesar $18 \pm 3,00 \mathrm{~mm}$ dan 17,66 $\pm 5,89 \mathrm{~mm}$ terhadap E.coli dan masih menunjukkan adanya aktivitas antibakteri pada konsentrasi $0.05 \%$ yang memiliki aktivitas antibakteri paling besar pada ekstrak isolat (S) terhadap S.aureus sebesar $11 \pm 1,00 \mathrm{~mm}$ dan ekstrak isolat (A) terhadap E.coli sebesar 11,33 $\pm 2,31 \mathrm{~mm}$ sehingga ekstrak isolat bakteri Aplysina sp dan Sarcophyton sp berpotensi sebagai antibakteri terhadap bakteri E.coli dan S. aureus.

Pemahaman tentang ffektifitas ekstrak bakteri yang berasosiasi dengan spons dan biota lainnya, termasuk karang lunak sebagai antibakteri penting untuk diketahui karena dapat dikembangakan lebih lanjut yang mengara kepada potensi pengembangan untuk obat. Resistensi bakteri patogen telah menjadi masalah terhadap kesehatan dan perlunya melakukan pencarian antibakteri baru untuk menghambat bakteri patogen. Potensi antibiotik telah banyak ditemukan dari sumber daya laut khususnya spons dan karang lunak. Pemahaman tentang sifat dan pengujian efektifitas dan KHM dari ekstrak bakteri yang berasosiasi dengan spons dan karang lunak terhadap bakteri E.coli, S.aureus dan jamur C. albicans. Pemahaman dan pengetahuan KHM biasanya dilakukan dengan metode ekstraksi isolat bakteri yang dilanjutkan dengan melakukan pengujian ekstrak sebagai antibakteri terhadap E.coli, S. aureus dan jamur C. albicans dalam konsentrasi $100 \%$ dan dilanjutkan dengan penetapan nilai KHM dengan konsentrasi 10\%, 5\%, 1\%, dan $0.05 \%$.

Hasil Efektifitas ekstrak bakteri dari isolat bakteri yaitu, (A) dan (S) menunjukkan aktivitas antibakteri paling besar terdapat pada konsentrasi $10 \%$ ekstrak isolat (S) terhadap S.aureus sebesar 18 $\pm 3,00 \mathrm{~mm}$ dan sebesar $17,66 \pm 5,89 \mathrm{~mm}$ terhadap E. coli. Konsentrasi hambat minimum masih menunjukkan adanya aktivitas antibakteri pada konsentrasi $0,05 \%$ yang 
memiliki aktivitas antibakteri yang paling besar pada ekstrak isolat (S) terhadap S.aureus sebesar 11 1,00 mm dan ekstrak isolat (A) terhadap E. coli sebesar 11,33 $\pm 2,31 \mathrm{~mm}$. Hasil ini menunjukkan ekstrak isolat bakteri Aplysina sp dan Sarcophyton sp berpotensi sebagai antibakteri terhadap bakteri E. coli dan S. aureus.

Riset-riset yang dilakukan untuk tujuan penelusuran senyawa aktif dari hasil metabolisme sekunder biota spons telah menghasilkan beberapa senyawa obat, antara lain adalah antimikroba, antikanker, anti virus dan lain-lain. Berikut adalah beberapa senyawa aktif dari biota spons yang berpotensi sebagai bahan farmasi. Senyawa antimikroba adalah senyawa kimia yang dapat menghambat pertumbuhan mikroorganisme tertentu. Sifat penghambatan ini dimanfaatkan dalam farmakologi sebagai obat terhadap penyakit yang umumnya disebabkan oleh mikroorganisme seperti bakteri, yeast dan jamur. Beberapa senyawa antimikroba yang telah diisolasi dari biota spons diantaranya adalah:

Chromodorolide A adalah senyawa diterpen yang mempunyai kerangka karbon yang berbeda dengan senyawa diterpen sebelumnya. Senyawa ini mempunyai aktivitas antimikroba dan sitotoksik. Chromodorolide tidak disintesa dalam tubuh spons, melainkan berasal dari nudibranch (Chromodoris sp) yang dimakannya.

Muqubilin, adalah senyawa peroksida siklik norsesterpen yang diisolasi dari spons Prianos sp. Organisme tersebut ditemukan dari Teluk Eilat. Senyawa ini mempunyai aktivitas sebagai antibiotik. Sigmosceptrellin-A adalah senyawa antimikroba peroksida siklik norsesterpen, yang tidak berbentuk kristal, penentuan strereokimia dari senyawa ini tidak dapat dilakukan dengan sinar x. Senyawa ini diisolasi dari spons jenis Sigmosceptrella laevis yang ternyata berasal dari pantai utara Papua New Guinea.

Aeroplysinin-1 yang diisolasi dari spons jenis Aplysina aerophoba. Senyawa ini dapat menghambat pertumbuhan bakteri Vibrio micrococcus atau Alteromonas sp. awah ini adalah struktur kimia dari senyawa aeroplysinin. Strongylophorines diisolasi dari spons Strongylophora durissina yang ditemukan di Papua New Guinea. Senyawa meroditerpenoid ini aktif menghambat bakteri Salmonella typhii dan Micrococcus luteus dengan zone diameter hambat bakteri 7-9 mm pada 
konsentrasi $100 \mu \mathrm{g} /$ disk. Oroidin adalah senyawa antibiotik sikloheksadiena yang mempunyai fungsi antiseptik seperti iodine tincture.

Aaptamine dan Demethylaaptamine adalah senyawa alkaloid yang mempunyai keaktifan menghambat pertumbuhan bakteri Staphylococcus aureus, Bacillus subtilis dan Vibrio eltor, sedangkan N-Amidino-4bromo-pyrole-2- carboxamide senyawa antibiotik yang diisolasi dari spons jenis Agelas sp. Sama halnya dengan 3,5-Dibromo-4hydroxyphenyl-acetamide dan 4- Acetamido-2,6-dibromo-4hydroxycyclo-hexadienon. Kedua senyawa ini mempunyai aktivitas sebagai antibiotik diisolasi dari spons Verongia archeri dan Verongia cauliformis. Avarol dan avaron adalah senyawa yang mempunyai keaktifan menghambat virus HIV. Senyawa ini dapat menghambat replikasi virus-HIV dan melindungi Tlymphoocytes dari infeksi virus.

Senyawa Antikanker yang berhasil diisolasi dari biota spons telah terbukti menghambat pertumbuhan sel kanker, berikut adalah senyawasenyawa antikanker yang ditemukan:

a) Spongouridin dan spongothymidine, adalah senyawa yang disintesa dari spons Cryptotetis crypta yang mempunyai keaktifan sitotoksik terhadap sel karsinoma pada manusia. Senyawa ini merupakan sebuah nukleosida yang berbeda dari biasanya dan dapat berfungsi sebagai terapi terhadap nukleosida virustatik AraA. Kedua senyawa ini merupakan zat aktif terhadap virus harpes simplex.

b) Adociaquinon B diisolasi dari spons Xestospongia sp., Senyawa ini aktif dalam menghambat pertumbuhan sel tumor

c) Bistratamide $\mathrm{D}$ diisolasi dari senyawa Lissoclinum bistratum. Senyawa ini aktif menghambat sel tumor HCT

d) Makaluvamine $\mathrm{N}$ Senyawa ini diisolasi dari Zyzzyafiiliginosa ditelusuri berasal dari Filipina, mempunyai keaktifan menghambat aktifitas katalitik topoisomerase

Selain senyawa-senyawa yang mempunyai keaktifan sebagai antimikroba dan antikanker, beberapa senyawa dari spons dapat digunakan juga sebagai lead compound obat antasida, antiepileptik, lipotropik dan hypotensif. a) Glisin diisolasi dari spons Zoanthids, senyawa ini mempunyai keaktifan sebagai antasida. b) Asam Glutamat, senyawa ini mempunyai keaktifan sebagai antiepileptik c) N,NDimethylhistamine, diisolasi dari spons Geodia gigas dan Ianthella sp. 
Senyawa ini mempunyai keaktifan sebagai hipotensif d) Metionin, senyawa ini mempunyai keaktifan sebagai lipotropic agent. Hasil metabolit sekunder dari beberapa spons terbukti mengandung senyawasenyawa aktif sebagai agent dalam pengembangan obat antibiotik, antikanker antivirus dan Iain-lain. Hal ini membuktikan bahwa spons sangat potensial dalam pengembangan industri farmasi, mengingat senyawa-senyawa aktif yang dihasilkan mempunyai perbedaan dengan senyawa yang dihasilkan oleh tumbuh-tumbuhan darat yang selama ini merupakan sumber utama bahan obat-obatan.

Temuan berbagai jenis senyawa aktif dari spons seperti di atas dapat dicapai dengan melakukan riset bertahun-tahun yang dilakukan oleh banyak lembaga riset dengan melibatkan berbagai disiplin ilmu yang berkolaborasi satu dengan lainnya yang membutuhkan berbagai instrument dalam melakukan identifikansi dan uji bioaktivitas zat aktif. Karenanya spons merupakan satu jenis biota laut yang dalam pengumkapan berbagai misteri yang terkandung di dalamnya dilakukan secara cermat dan sangat teliti, karena ternyata subtansi dari temuan zat aktif spons umumnya menyangkut kemaslahatan umat manusia, sehingga spons merupakan objek penting dalam riset dewasa ini. Indonesia yang memiliki populasi spons terbesar di dunia patut bersyukur karena bukan tidak mungkin Negara kita menjadi rujukan dalam penelusuran berbagai senyawa aktif khususnya dari spons. Untuk itulah diperlukan penelitian lebih lanjut dan terpadu dalam mengungkap misteri terkait dengan zat bioaktif dari spons.

\section{2. Komponen Pengedradasi}

Pengolahan limbah minyak bumi dilakukan secara fisika, kimia dan biologi. Pengolahan secara fisika dilakukan untuk pengolahan awal yaitu dengan cara melokalisasi tumpahan minyak menggunakan pelampung pembatas (oil booms), yang kemudian akan ditransfer dengan perangkat pemompa (oil skimmers) ke sebuah fasilitas penerima "reservoar" baik dalam bentuk tangki ataupun balon dan dilanjutkan dengan pengolahan secara kimia, namun biayanya mahal dan dapat menimbulkan pencemar baru. Pengolahan limbah secara biologi merupakan alternatif yang efektif dari segi biaya dan aman bagi lingkungan. Pengolahan dengan metode biologis disebut juga bioremediasi, yaitu bioteknologi yang 
memanfaatkan makhluk hidup khususnya mikroorganisme untuk menurunkan konsentrasi atau daya racun bahan pencemar terkomposisi hidrokarbon.

Mikroorganisme, terutama bakteri yang mampu mendegradasi senyawa yang terdapat di dalam hidrokarbon minyak bumi disebut bakteri hidrokarbonoklastik. Bakteri ini mampu mendegradasi senyawa hidrokarbon dengan memanfaatkan senyawa tersebut sebagai sumber karbon dan energi yang diperlukan bagi pertumbuhannya. Mikroorganisme ini mampu menguraikan komponen minyak bumi karena kemampuannya mengoksidasi hidrokarbon dan menjadikan hidrokarbon sebagai donor elektro. Mikroorganisme ini berpartisipasi dalam pembersihan tumpahan minyak dengan mengoksidasi minyak bumi menjadi gas karbon dioksida $\left(\mathrm{CO}_{2}\right)$, bakteri pendegradasi minyak bumi akan menghasilkan bioproduk seperti asam lemak, gas, surfaktan, dan biopolimer yang dapat meningkatkan porositas dan permeabilitas batuan reservoir formasi klastik dan karbonat apabila bakteri ini menguraikan minyak bumi.

Berikut adalah reaksi degradasi senyawa hidrokarbon fraksi aromatik oleh bakteri yang diawali dengan pembentukan catechol atau senyawa yang secara struktur berhubungan dengan senyawa organik sederhana. Kedua senyawa ini selanjutnya didegradasi menjadi senyawa yang dapat masuk ke dalam siklus Krebs (siklus asam sitrat), yaitu suksinat, asetil KoA, dan piruvat. Bakteri hidrokarbonoklastik diantaranya adalah Pseudomonas, Arthrobacter, Alcaligenes, Brevibacterium, Brevibacillus, dan Bacillus. Bakteri-bakteri tersebut banyak tersebar di alam, termasuk dalam perairan atau sedimen yang tercemar oleh minyak bumi atau hidrokarbon. Kita hanya perlu mengisolasi bakteri hidrokarbonoklastik tersebut dari alam dan mengkulturnya, selanjutnya kita bisa menggunakannya sebagai pengolah limbah minyak bumi yang efektif dan efisien, serta ramah lingkungan.

Beberapa jenis bakteri yang telah terbukti dapat mereduksi sifat racun dari komponen hidrokarbon golongan poli aromatik dapat diperoleh dengan metode isolasi dari lumpur yang terpapar dengan jenis hidrokarbon tertentu dan yang sedang diteliti saat ini adalah penelusuran jenis bakteri yang dapat mendegradasi hidrorbon dari biota laut termasuk mangrove. Biota laut yang sangat potensial untuk dilakukan analisis 
terkait dengan bakteri potensial tertentu adalah bakteri yang berasosiasi dengan spons yang kita kenal dengan sebutan mikrosimbion. Hampir semua jenis spons bersimbion dengan mikroorganimse tertentu, namun jenis bakteri simbion sangat bervariasi tergantung pada dinamikan pertumbuhan dan perkembangan spons pada suatu populasi atau habitat baik dengan lingkungannya maupun dengan nutrisi dan ancaman predator.

Jenis bakteri simbion spons yang telah terbukti dpat mendegradasi komponen hidrokarbon adalah Pseudomonas sp, Bacillus subtilis, Bacillus flexus, dimana bakteri tersebut diisolasi dari spons jenis Callyspongia sp. Ketiga jenis bakteri tersebut dapat mereduksi komponen hidrokarbon jenis PAH yakni pyrene dengan tingkat degradasi mencapai $85 \%$ pada kontak antara suspensi bakteri simbion spon tersebut dengan pyrene selama 25 hari dalam keadaan media degradasi suhu kamar dan dilakukan aerasi. Temuan tersebut adalah sebuah hasil awal dari suatu jenis bakteri simbion spons yang dapat mendegradasi komponen hidrokarbon. Karenanya diperlukan tindak lanjut dan riset lebih lanjut terkait dengan hal ini mengingat bahwa puluhan ribu jenis spons yang juga diketahui setiap jenis spons dapat bersimbion dengan sedikitnya 1-8 jenis bakteri. Dugaan awal bahwa mekanisme bakteri dalam mendegradasi komponen hidrokarbon adalah terletak pada kemampuan bakteri tersebut menghasilkan suatu zat yang dapat melindungi diri bakteri sebagai respon atas ancaman yang diterima oleh bakteri dari sifat racun hidrokarbon tersebut. Produksi zat ini dihasilkan oleh bakteri dengan memanfaatn carbon dari hidrokarbon sebagai sumber makanan dan kemamouan untuk mengkorversi ke dalam bentuk energy untuk menghasilkan zat tertentu pula yang spesifik untuk pertahanan dirinya. Karena itu diperlukan riset konprehensif dan kontinyu untuk melihat fenomena ini.

\section{3. Spons Sebagai Bioabsorpben Logam Berat}

Paparan logam berat dalam lingkungan sulit dihindari, disebabkan karena aktivitas manusia yang tidak bisa terlepas dari penggunaan bahan bakar dalam system transfortasi baik didarat, di laut maupun di udara termasuk bahan bakar mesin-mesin produksi yang menghasilkan zat buangan berupa polutan berkontribusi besar dalam menurunkan kualitas lingkungan. Kegiatan pengeborang minyak bumi, transfortasi laut, kecelakaan kapal pengangkut minyak bumi, termasuk pada cucian kapal 
tenker yang menghasilkan ballas, kesemuanya berkontribusi dalam menambah kadar polutan di dalam laut, dimana diketahui bahwa minyak bumi selain mengangdung hidrokarbon juga mengangandung logam berat seperti $\mathrm{Ni}, \mathrm{Pb}, \mathrm{Cr}, \mathrm{Cd}, \mathrm{Hg}$, As, Zn dan jenis logam berat lainnya. Aktivitas alam seperti letusan gunung berapi yang banyak memuntahkan partikelpartikel polutan logam berat.

Tinjauan mikrosimbion spons yang memiliki kemampuan memproduksi zat tertentu untuk menangkal serangan predator yang mengancam kelangsungan hidupnya, dimana za tersebut berperilaku seperti enzim. Komponen enzim adalah mengandung protein tertentu dan asam amino, sedangkan sel bakteri simbion juga tersusun oleh DNA, sehingga kombinasi dari kedua senyawa tersebut diduga dapat membentuk susunan senyawa yang permukaannya menghasilkan ion-ion negatif. Dengan adanya ion logam seperti $\mathrm{Pb}^{2+}$, diperkirakan dapat membentuk perikantan satu dengan lainnya dalam bentuk ikatan kimia atau dapat membentuk senyawa komplek, dimana ion-ion positif dari logam akan terperangkap dalam kerangka senyawa kompleks protein. Meskipun diketahui bahwa logam berat dapat membentuk ion yang berbeda-beda, bisa dalam bentuk ion positif satu, positif dua, positif tiga bahkan beberapa logam berat dapat memiliki muatan ion lebih dari satu, sehingga perikatan kompelks protein zat yang diproduksi oleh bakteri simbion spons atau kompleks DNA dari susunan sel bakteri simbion akan membentuk suatu mekanisme perikatan yang berbeda-beda satu dengan lainnya.

Bagaimana bentuk perikatan antara suatu jenis logam dengan zat produksi bakteri simbion dan bentuk perikatan antara ion logam dengan DNA dari sel bakteri selanjutnya membutuhkan penelitian lebih lanjut dan konprehensif. Hal inilah yang dimaksudkan dari judul bab ini dimana spons dikatakan sebagai objek riset. Begitu banyak potensi riset yang dapat dilakukan terkait dengan spons, mikrosimbion spons kaitannya dengan pencemaran logam berat, polutan minyak bumi maupun oleh kemampuan spons menghasilkan berbagai senyawa kimia yang semuanya memerlukan pemecahan ilmiah.

\section{4. Potensi Mikrosimbion Spons Sebagai Biomaterial}

Biomaterial dari spons berupa spons itu sendiri, biomassa spons, mikrosimbion spon dan zat aktif atau komponen kimia yang dihasilkan oleh spons memiliki potensi untuk dimanfaatkan dalam berbagai aspek 
dan tujuan, diantaranya biomassa spons dan mikrosimbionnya, berpotensi digunakan sebagai bahan pendegradasi komponen karsinogenik dan mutagenik dari hidrokarbon jenis poli aromatik. Demikian pula bahwa baik biomassa maupun mikrosimbion spon juga potensial untuk digunakan sebagai material dalam mereduksi sifat toksik dari logam berat. Pemanfaatan lain dari mikrosimbion spons adalah pengkajian tentang potensinya sebagai material penyambung atau pengelem tembok yang retak oleh produksi zat perilaku enzim dari bakteri tersebut dan bahkan untuk pengembangan lebih lanjut pada penggunaan mikrosimbion spons sebagai salah satu bahan pencampur cat tembok untuk mengatasi terbentuknya lumut pada tembok yang sudah lamah terpapar cahaya matahari, air hujan, dan hempasan angina yang merupakan suatu dinamika dan menyebabkan terjadinya interaksi material-material permukaan tembok yang dapat menghasilkan lumut yang pada akhirnya dapat merusak fungsi dari tembom tersebut dan juga merusak estetika dan keindahan tembok dimana warna tembok akan pudar bahkan dapat ditumbuhi jenis tumbuhan tertentu jenis lumut.

Penambahan mikrosimbion dalam cat tembo tersebut dimaksudkan untuk menghasilkan suatu zat yang dapat melindungi cat tersebut dari paparan cahaya matahari dan hujan termasuk hempasan angina sehingga terbok tersebut tetap dapat memancarkan cahaya aslinya sebagaimana warna awalnya. Semua potensi pemanfaatan di atas membutuhkan suatu pengkajian lebih dalam dan lengkap.

Aspek zat bioaktif yang dihasilkan oleh spons tidak kala menariknya untuk diikaji secara dalam. Zat bioaktif yang kita kenal dengan metabolik sekunder cukup beragam dan potensi pemanfaatannya juga cukup banyak dan signifikan sangat dibutuhkan dalam berbagai bidang ilmu, terutama ilmu obat-obatan, ilmu kedokteran khususnya untuk jenis penyakit kronis dan generative seperti kanker, tumor dan lain sebagainya.

\section{5. Spons Objek Potensial Pengembangan Destinasi Wisata}

Pertumbuhan spons yang membentuk koloni antara sesame spons dengan berbagai jenis dapat menjadi suatu pemandangan yang unik. Beberapa faktor yang menjadi ciri dari spons, khususnya spons yang hidup 
dan berkembangbiak pada lingkungan alami dengan tanpa gangguan seperti sedimentasi, dan faktor-faktor yang mendukung pertumbuhannya terpenuhi seperti penyinaran, dengan arus dan gelombang yang sedang akan tampak lebih menarik, seperti bentuk tubuh dari setiap jenis spons yang unik, pancaran warna yang tampak, serta gerakan-gerakn spons baik karena gerakan yang disebabkan oleh arus dan gelombang juga karena pergerakan alami spons yang berlainan satu dengan spons lainya yang memiliki jenis yang berbeda.

Penampakan warna, bentuk tubuh dan pergerakan spons sangat menarik untuk diamati, relatif serupa ketika kita melihat pergerakan ikan di dalam aquarium. Jika area dimana koloni spons hidup dapat dijaga seperti kekeruhan, cemaran sampah khususnya benda-benda golongan plastik, maka dapat dikatakan bahwa koloni spons senantiasa memancarkan aura kebahagian dan kesenangan bagi siapa saja yang memandangnya. Panorama spons yang berada dalam air semakin indah ketiha diantara spons-spons tersebut terdapay ikan warni-warni yang berenang dan sesekali bercengkrama, sunggu menyuguhkan suatu situasi yang menyenangkan bagi setiap yang memandangnya. Panorama spons terlihat berbeda ketika di lihat pada waktu hujang dengan pada saat cerah dengan pancaran sinar matahari. Panorama spons dapat berubah (warna dan bentuk) dalam waktu hitungan hari sedangkan gergerakan spons akan berubah setiap saat sehingga situasi seperti ini akan menambah kekuatan spons sebagai suatu objek wisata. Ketika kita melihat adanya beberapa jenis spons yang dapat menyemprotkan cairan tertentu dengan warna yang berbeda seperti semprotan warna kuning, warna biru dan lain sebagainya semakin menguatkan bahwa spons merupakan jenis hewan penting. Keadaan inilah yang dimaksud spons sebagai objek wisata bawah laut dan dapat dikembangan sebagai area destinasi wisata bahari. 


\section{Bab -9-}

\section{TRANSPLANTASI SPONS}

\section{1. Transplantasi Spons Suatu Metode Pelestarian Aquarium Laut}

Transplantasi adalah suatu metode penyambungan organ atau dikenal dengan cangkok atau dapat juga dikatakan pemindahan seluruh atau sebagian organ dari satu tubuh ke tubuh yang lain, atau dari suatu bagian ke bagian yang lain pada tubuh yang sama atau sejenis, biasanya untuk tujuan peremajaan. Transplantasi spons mengambil istilah medis yang ditujukan untuk menggantikan atau menyambung organ/tubuh sebagian atau seluruh tubuh spons baik karena mengalami kerusakan atau karena ingin dilakukan pertumbuhan pada area yang lain untuk kepentingan penyelamatan dan pelestarian lingkungan ataupun untuk kepentingan riset. Tubuh spons yang dapat ditransplantasi adalah berupa tunas dengan cara memindahkan tunas tertentu untuk ditumbuhkan pada area atau lokasi lain. Transplantasi spons yang pernah dilakukan di Indonesia seperti jenis tertentu, diantaranya jenis Auletta sp., di Sulawesi Selatan pada kedalaman 7 meter dengan panjang fragmen $5 \mathrm{~cm}$. Transplantasi yang dilakukan bertujuan untuk mengetahui pertumbuhan dan bagaimana kelangsungan hidup dari spons tersebut pada saat dilakukan Transplantasi.

Pembahasan Spons laut dapat hidup di berbagai habitat seperti pasir, karang mati, batu serta pada media apapun yang mempunyai struktur keras. Pada substrat beton spons laut dapat melekat dengan baik karena struktur substrat yang keras dan kasar sehingga memudahkan spons untuk melekat pada media tersebut oleh karena itu spons dikatakan bersifat sesil yang artinya melekat dan menetap pada suatu substrat.

Spons termasuk Filum Porifera yang dibagi menjadi 4 kelas yaitu Calcarea, Hexactinellida, Archaeocyatha (punah) dan Demospongiae. Kelas Demospongiae hampir mencapai 90\% dari sekitar 4500- 5000 spesies spons yang telah diidentifikasi, dari total spesies yang hidup di dunia. Kelas ini dibagi menjadi 3 subkelas, 13 ordo, 71 famili dan 1005 genera, meskipun hanya 507 genera yang dinyatakan masih ada, 481 genera hidup diperairan laut dan 26 genera hidup di air tawar. Kelas Demospongiae adalah spons yang paling banyak ditemukan dan 
penyebarannya luas, jenis-jenisnya paling beragam dan relatif banyak mendapatkan perhatian dari para ahli biokimia dan kimia organik. Beberapa tahun terakhir ini para peneliti lebih mencurahkan perhatiannya pada spons, berkaitan dengan senyawa bahan alam (metabolit sekunder) yang terkandung di dalamnya. Senyawa bahan alam ini banyak dimanfaatkan dalam bidang farmasi, karena memiliki sifat bioaktif. Selain sebagai sumber senyawa bahan alam, spons juga memiliki manfaat antara lain, sebagai indikator biologi untuk pemantauan pencemaran laut, indikator dalam interaksi komunitas dan sebagai hewan penting untuk akuarium laut yang tentunya memegang peran penting untuk menjamin kelestariannya. Metode budidaya spons perlu dilakukan yang selama ini dipraktekkan dengan cara transplantasi, meskipun ulasan tentang transplantasi spons di Indonesia belum banyak dilakukan atau masih dalam tahap uji coba untuk kepentingan riset yang juga masih dilakukan secara terpisah dan dalam skala kecil.

\section{2. Metode Transplantasi Spons}

Beberapa metode transplantasi yang biasa dilakukan, seperti perlakuan perbedaan dan posisi substrat, yaitu 1) batu yang dibungkus jaring poliethylen (BP), 2) jaring poliethylen dengan posisi vertikal (PV), dan 3) jaring poliethylen dengan posisi horizontal (PH). Biasanya pengamatan yang dilakukan terhadap spons yang di transplantasikan, adalah: 1) kecepatan pertumbuhan spons; 2) faktor-faktor yang mempergaruhi pertumbuhan; 3) metode transplantasi; 4) kedalaman transplantasi, dan 5) jenis spons yang dapat di transplantasikan. Lama pengamatan umumnya dilakukan selama 90 sampai dengan 180 hari dengan cara melakukan pencatanan atas pertumbuhan spons berupa pertambahan tinggi, lebar, warna selama dalam proses transplantasi dilakukan setiap 2 minggu sekali. Pengamatan berupa observasi atas dinamika transplantasi. Untuk kasus seperti di atas dengan tiga jenis variasi transplantasi, dimana pertumbuhan spons transplantasi lebih baik pada substrat BP dibandingkan dengan substrat PV dan PH. Kondisi tersebut dimungkinkan oleh bentuk permukaan substrat yang keras dan tertutup sehingga energi yang dikeluarkan untuk melakukan penempelan lebih sedikit. 
Banyak hal yang harus diperhatikan dalam melakukan transplantasi spons, termasuk penyediaan wadah transplantasi. Wadah transplantasi ynag umum biasanya: ukuran $20 \mathrm{~cm}$ x $20 \mathrm{~cm}$ x $9 \mathrm{~cm}$, lalu diikatkan tali yang saling menyilang pada kedua bagian sisi batako untuk tempat mengikat organisme uji. Bentuk ini dibuat agar media transplantasi tidak mudah berpindah dari tempatnya meskipun lokasi penelitian berarus kencang. Substrat transplantasi digambarkan dalam Gambar 9.1 dan 9.2., sebagai berikut:

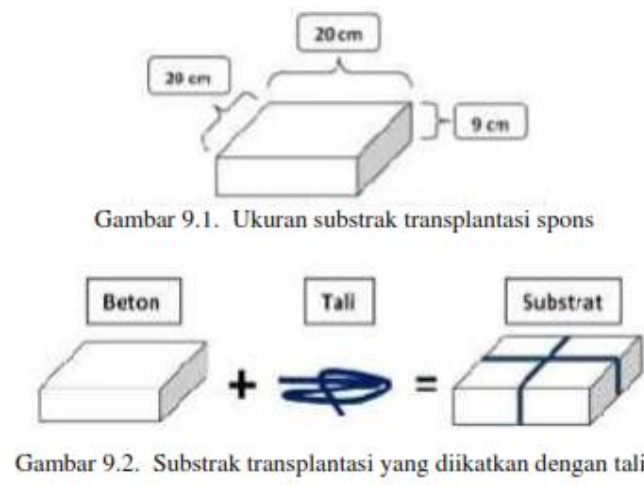

Pemasangan bibit pada percobaan transplantasi spons ini dilakukan dengan metode pencangkokan, kemudian diikatkan pada media atau substrat yang telah tersedia. Pemotongan bibit dari induk asalnya diambil pada lokasi yang tidak terlalu jauh dari lokasi penelitian yaitu \pm 1 $\mathrm{km}$. Bibit diambil dengan cara dipotong pada bagian pangkal spons dengan menggunakan pisau. Setelah dilakukan pengambilan maka bibit dikumpulkan kedalam wadah ember yang berisi air laut. Setelah bibit terkumpul maka dilakukan pemotongan kembali untuk ukuran besaran bibit yang dipakai. Ukuran bibit yang digunakan adalah panjang $3 \mathrm{~cm}$, tinggi $3 \mathrm{~cm}$, dan lebar $2 \mathrm{~cm}$. Bentuk dan ukuran dapat dilihat pada Gambar 9.3, berikut:

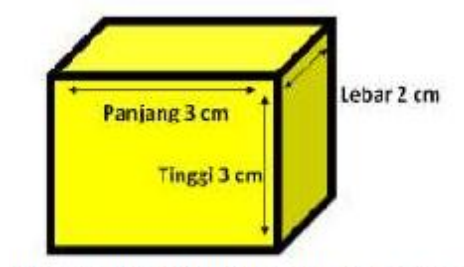

Gambar 9.3. Bentuk dan ukuran potongan bibit spons transplantasi 


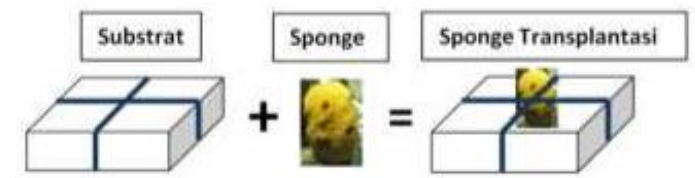

Gambar 9.4. Bibit uji spons yang telah dipasang pada substrak tranplantasi.

Subtrak transplantasi spons harus dipastikan terbuat dari wadah yang baik dan kuat, agar dapat menopang kehidupan spons transplantasi dari terjangan arus laut, hempasan gelombang dan bahkan diharapkan dapat melindungi fragmen spons dari pengaruh buruk sedimentasi.

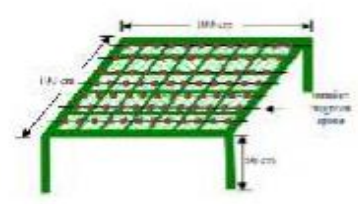

herimetel

Gambar 9.5. Bentuk rak dan pengikatan fragmen spons pada rak

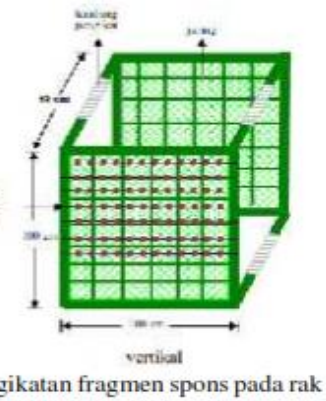

Sama halnya dengan rak subrak yang berisikan bibit spon transplantasi, harus terbuat dari bahan yang kuat dan dapat sebagai tempat untuk pengikatan substrat. Rak harus dirancang sedemikian rupah agar dapat menjadi penopang kehidupan spons tranpalntasi.

Pemasangan bibit harus dilakukan di dalam air untuk menghindari spons laut mengalami stres akibat perubahan fisika kimia perairan. Caranya dengan mengikatkan bibit spons ke tali yang telah tersedia pada wadah transplantasi yaitu dengan menggunakan tali "tie" (tali plastik). Proses penempelan lebih baik untuk mendukung pertumbuhan. Kelangsungan hidup spons tidak berbeda jauh yaitu berkisar antara 70, 83 - 76,67\%. Transplantasi spons juga telah dilakukan di Spermonde, Indonesia selama 6 bulan menggunakan dua teknik transplantasi yaitu jaring dan tali. Pada metode yang digunakan ini, transplantasi dilakukan untuk spons jenis Callyspongia (Euplacella) biru berukuran $30-40 \mathrm{~mm}$ diletakkan secara horizontal dengan menggunakan rak berukuran 70x100cm. Selanjutnya rak diletakkan di kedalaman 12 - $15 \mathrm{~m}$ pada dua lokasi yang berbeda yaitu daerah terlindung dan terbuka. Sebanyak 250 fragmen spons di transplantasikan selama 6 bulan. Hasil yang diperoleh 
menunjukkan bahwa spons Callyspongia yang di transplantasikan menunjukkan pertumbuhan yang baik dan tergolong cepat yang ternyata spons transplantasi yang diletakkan pada area terbuka (terpapar) cahaya matahari menunjukkan pertumbuhan yang lebih baik dibandingkan pada transplantasi yang diletakkan pada area tertutup. Hal ini menunjukkan bahwa pengaruh cahaya matahari berpengaruh pada pertumbuhan spons.

Jenis spon lain yang pernah ditransplantasikan adalah jenis spons Aaptos aaptos yang dilakukan di Sulawesi Selatan pada beberapa lokasi dan habitat yang berbeda, bertujuan untuk melihat pertumbuhan dan kelangsungan hidup spons tersebut. Lokasi yang dipilih adalah pulau Barrang Lompo (PBL) dan pulau Samalona (PSL), kedua pulau ini masuk dalam wilayah pesisir Makassar yang merupakan bagian dari gugusan kepulauan Spermonde. Pada metode ini, Spons diletakkan di habitat dasar yang berbeda yaitu dasar berpasir (BPR), dasar rubble (RBL) dan berkarang (BKR). Ukuran fragmen sebesar $4 \times 4 \times 4 \mathrm{~cm}^{3}$ dan pertumbuhan yang diukur adalah pertumbuhan panjang. Setelah 5 bulan pemeliharaan diketahui bahwa pertumbuhan rata-rata spons yang ditransplantasi di PBL sama dengan di PSL. Pertumbuhan rata-rata di PBL dan PSL pada habitat BKR lebih tinggi dari pada habitat BPR dan RBL. Kelangsungan hidup di PBL lebih tinggi dari pada PSL. Kelangsungan hidup di PBL pada habitat RBL lebih tinggi dari pada habitat BPR dan BKR, sedangkan kelangsungan hidup di PSL pada habitat BPR lebih tinggi dari pada habitat RBL dan BKR.

Transplantasi spons khususnya di Sulawesi selatan juga pernah dilakukan di Kabupaten Maros untuk spons jenis Aulletta sp., yang bertujuan untuk mendapat gambaran potensi spons Callyspongia (Euplacella) biru yang ada di Kepulauan Spermonde Sulawesi Selatan untuk dilakukan transplantasi, sedangkan transplantasi spons yang dilakukan di luar negeri yaitu untuk jenis spons spesies Latrunculia brevis, Petrosia nigricans dan Polymastia croceus menggunakan metode substrat jaring dan tali, sedangkan transplantasi spons Spongia officinalis dan Hippospongia communis dilakukan pada substrat tali nilon. Transplantasi spons Petrosia nigricans yang dilakukan menggunakan metode substrat jaring dan tali dilakukan dengan pertimbangan spons ini relatif mudah beradaptasi. Pertumbuhan dan tingkat kelangsungan hidup spons $P$. nigricans yang ditransplantasikan pada kondisi perairan yang berbeda. 
Transplantasi spons juga telah dilakukan di Kepulauan Seribu yang dilakukan di dua lokasi yaitu perairan Pulau Pari (5 '51'56.3” LS - 106 '37'01.6” BT) dan Pulau Pramuka (06 45'6” LS - 106 32‘45” BT) yang perairannya berbeda kondisi fisik, dan kimianya. Pulau Pari terletak lebih dekat daratan (Jakarta), mewakili perairan yang banyak mendapat masukan nutrien dari Teluk Jakarta dan perairan Gosong Pramuka mewakili perairan yang jauh dari daratan. Perairan Pulau Pari dan Pulau Pramuka berjarak \pm 11.26 mill dan \pm 20.12 mill dari daratan terdekat.

Pemilihan induk spons sebagai bahan fragmen diambil dari Pulau Pari. Cara kerja transplantasi diawali dengan memilih indukan spons, dipotong secara in situ dan disisakan sekitar $30 \%$ dari volume awal, untuk memberikan kesempatan beregenerasi. Fragmen spons dipotong berbentuk kubus $\left(5 \times 5 \times 5 \mathrm{~cm}^{3}\right)$ dengan bobot rata-rata 25 gram. Tiap fragmen, paling sedikit mempunyai satu sisi yang tidak terpotong, dengan seluruh pinacoderm dan oskula. Setelah spons dipotong sesuai ukuran, bagian tengahnya dilubangi lalu dilewatkan seutas tali polyetheline (diameter $4 \mathrm{~mm}$ ). Jarak antara satu fragmen spons dengan fragmen spons yang lainnya sekitar $10 \mathrm{~cm}$ dan jarak antar tali satu dengan yang lainnya sekitar $33 \mathrm{~cm}$. Fragmen kemudian dijalin pada seutas tali dan diikatkan pada kerangka besi beton berukuran 1x1 m2. Fragmen bertali kemudian diletakkan di dasar perairan berkarang dengan posisi horizontal, yaitu di Pulau Pari dan Pulau Pramuka pada kedalaman 7 meter dan 15 meter. Di setiap lokasi diletakkan 1 transek yang berisi 30 fragmen spons. Pengukuran dilakukan setiap bulan secara langsung di dalam air, dengan menggunakan jangka sorong (calipper). Pengukuran pertumbuhan sampai akhir pengamatan dilakukan dengan pengukuran volume yaitu pertumbuhan panjang, lebar dan tebal spons. Pertumbuhan mutlak dan pertumbuhan bulanan diketahui dengan mengunakan formula tertentu.

Tingkat kelangsungan hidup spons diketahui dengan membandingkan jumlah fragmen spons yang hidup di akhir percobaan dengan jumlah fragmen spons pada awal perlakuan. Perbedaan kualitas air perairan (suhu, kecerahan, kecepatan arus permukaan, salinitas, pH, TSS, DO, fosfat dan nitrat) pada kedua lokasi perlakuan diuji dengan uji " $t$ " berpasangan. Analisis pengaruh kedalaman lokasi dan waktu (bulan) terhadap pertumbuhan dan kelangsungan spons dilakukan dengan analisis varian dengan Rancangan Acak Kelompok (RAK). Uji lanjut yang 
digunakan adalah uji Beda Nyata Terkecil (BNT0.05) pada selang kepercayaan 95. Hasil eksperimen diketahui bahwa pertumbuhan spons Petrosia nigricans selama 12 bulan selengkapnya disajikan pada Tabel 9.1, dan Gambar 9.5, berikut:

Tabel 9.1. Rata-rata hasil pengukuran parameter kualitas air selama penelitian di perairan Pulau Pari dan Pulau Pramuka.

\begin{tabular}{|c|c|c|c|c|c|}
\hline \multirow{3}{*}{ Parameter } & \multirow{3}{*}{ Satuan } & \multicolumn{4}{|c|}{ Lokasi Perairan } \\
\hline & & \multicolumn{2}{|c|}{ P. Pari } & \multicolumn{2}{|c|}{ P. Pramuka } \\
\hline & & $7 \mathrm{~m}$ & $15 \mathrm{~m}$ & $7 \mathrm{~m}$ & $15 \mathrm{~m}$ \\
\hline Suhu & ${ }^{\circ} \mathrm{C}$ & $29.50 \pm 0.71$ & $29.23 \pm 0.75$ & $29.50 \pm 0.76$ & $29.15 \pm 0.88$ \\
\hline Salinitas & ppt & $32.23 \pm 1.11$ & $32.35 \pm 1.11$ & $32.77 \pm 0.97$ & $32.85 \pm 0.96$ \\
\hline Kecerahan & $\mathrm{m}$ & \multicolumn{2}{|c|}{$7.23 \pm 1.25$} & \multicolumn{2}{|c|}{$11.42 \pm 0.96$} \\
\hline Arus permukaan & $\mathrm{m} / \mathrm{det}$ & \multicolumn{2}{|c|}{$0.48 \pm 0.25$} & \multicolumn{2}{|c|}{$0.35 \pm 0.23$} \\
\hline $\mathrm{pH}$ & & $8.04 \pm 0.05$ & $8.04 \pm 0.05$ & $8.05 \pm 0.05$ & $8.05 \pm 0.05$ \\
\hline TSS & $\mathrm{mg} / \mathrm{l}$ & $5.92 \pm 1.80$ & $6.00 \pm 1.73$ & $4.54 \pm 1.39$ & $4.62 \pm 1.32$ \\
\hline TOM & $\mathrm{mg} / \mathrm{l}$ & $14.09 \pm 2.64$ & $15.14 \pm 2.55$ & $12.64 \pm 1.74$ & $13.29 \pm 1.98$ \\
\hline DO & $\mathrm{mg} / \mathrm{l}$ & $6.25 \pm 0.63$ & $6.22 \pm 0.63$ & $7.01 \pm 0.79$ & $6.84 \pm 0.85$ \\
\hline Fofat & $\mathrm{mg} / \mathrm{l}$ & $0.010 \pm 0.003$ & $0.011 \pm 0.003$ & $0.008 \pm 0.002$ & $0.008 \pm 0.002$ \\
\hline Nitrat & $\mathrm{mg} / \mathrm{l}$ & $0.084 \pm 0.014$ & $0.085 \pm 0.014$ & $0.076 \pm 0.015$ & $0.077 \pm 0.015$ \\
\hline
\end{tabular}

Tabel 9.1 memperlihatkan hasil pengukuran parameter air selama masa pengamatan pertumbuhan spons trasplantasi yang dilakukan di lokasi budidaya Pulau Pari dan Pulau Pramuka, keduanya merupakan bagian dari gugusan kepulauan Seribu, Jakarta. Pengukuran parameter air seperti suhu, salinitas, pH TSS, arus permukaan dan arus bawah merupakan faktor yang berpengaruh terhadap keberhasilan pertumbuhan fragmen transplantasi spons.

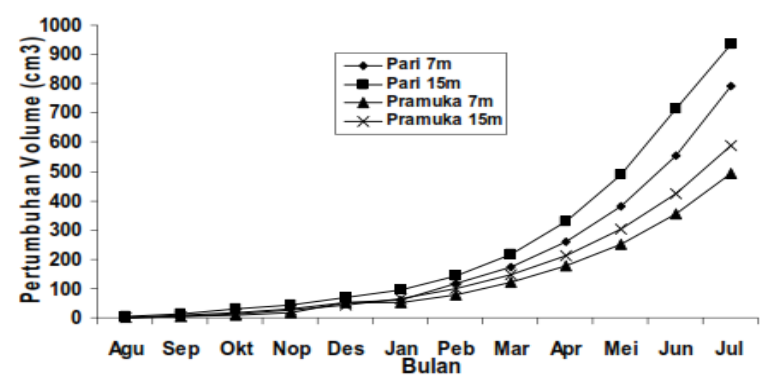

Gambar 9.6. Pertumbuhan bulanan (cm3) transplantasi spons Petrosia nigricans di Pulau Pari dan Pulau Pramuka di Kepulauan Seribu

Gambar 9.6 adalah grafik yang menunjukkan pertumbuhan dan perkembangan rata-rata spons transplantasi, dimana terlihat bahwa ada 
kecenderungan nilai pertumbuhan yang semakin besar seiring dengan bertambahnya waktu transplantasi.

Pada lingkungan yang berbeda, menghasilkan respon pertumbuhan yang relatif berbeda. Lebih tingginya pertumbuhan spons di perairan Pulau Pari dibandingkan Pulau Pramuka diakibatkan perbedaan kondisi kualitas air. Berdasarkan data kualitas air (Tabel 9.1) dan analisis uji t berpasangan berpasangan menunjukkan nilai kecerahan, kecepatan arus, salinitas, TOM, TSS, DO, nitrat, dan fosfat antar lokasi penelitian menunjukkan perbedaan yang nyata $(\mathrm{p}<0.05)$ dan tidak berbeda nyata antar kedalaman perairan ( $p>0.05)$. Nilai TOM menunjukkan perbedaan yang nyata $(\mathrm{p}<0.05)$ antar lokasi dan kedalaman perairan Pulau Pari dan Pramuka. Pergerakan massa air yang tinggi akan meningkatkan pertumbuhan spons.

Gambar 9.6, di atas memperlihatkan rata-rata pertumbuhan volume spons Petrosia nigricans tidak merata antar kedalaman lokasi dan waktu pengawatan. Rata-rata pertumbuhan mutlak selama 1 tahun di perairan Pulau Pari adalah 7 meter dan 15 meter, serta pada Pulau Pramuka juga mencapai 7 meter dan 15 meter berturut-turut sebesar 793.19, 936.60, $493.19 \mathrm{~cm}^{3}$, dan $590.02 \mathrm{~cm}^{3}$. Hasil analisis ragam pertumbuhan menunjukkan berpengaruh secara nyata pada kedalaman lokasi dan waktu pengamatan $(\mathrm{P}<0.05)$. Hasil uji BNT terhadap rata-rata pertumbuhan antar kedalaman lokasi menunjukkan adanya perbedaan yang nyata $(\mathrm{P}<$ 0.05) antar semua kedalaman lokasi. Hasil Uji BNT terhadap pertumbuhan bulanan menunjukkan terdapat perbedaan yang nyata $(\mathrm{P}<0.05)$ pada setiap pengukuran. Fase pertumbuhan spons yang ditransplantasikan dimulai setelah fase statis (pertumbuhan tidak bertambah) selama 5-20 hari pertama. Pertumbuhan rata-rata bulanan fragmen spons di kedua lokasi eksperimen pada bulan pertama sampai ke tiga menunjukkan nilai yang rendah namun terus meningkat pada bulan ke empat sampai akhir pengamatan setelah 1 tahun, menunjukkan terjadinya pertumbuhan yang terus menerus.

Peningkatan pertumbuhan disebabkan oleh semakin sempurnanya sistem saluran air dan pigmentasi warna spons yang ditandai dengan semakin banyaknya jumlah ostia dan oskula. Sempurnanya pigmentasi dan meningkatnya jumlah mikroba simbion ditandai dengan munculnya warna alami spons $P$. nigricans yaitu kecoklatan, mengindikasikan spons 
memiliki warna yang berbeda, walaupun dalam satu jenis. Spons yang hidup di lingkungan gelap, berbeda warnanya dengan spons sejenis yang hidup pada lingkungan dengan kecerahan sinar matahari cukup atau terang. Warna spons sebagian dipengaruhi oleh fotosintesa mikrosimbionnya yaitu cyanobakteri dan eukariot alga, seperti dinoflagella atau zooxanthella. Pada eksperimen ini, terlihat pertumbuhan $P$. nigricans di kedua lokasi lebih cepat dibandingkan hasil eksperimen yang lain. Selama 1 tahun terjadi pertumbuhan 402.34-540, $93 \%$. Peningkatan volume terbesar $P$. nigricans terjadi di perairan Pulau Pari pada kedalaman $15 \mathrm{~m}(638,67 \%)$ hampir sama dengan spons jenis Latrunculia wellingtonensis (700\%) yang di transplantasi dengan metode tali di Wellington Harbour, Selandia Baru, namun transplantasi di Selandia Baru pada jenis Latrunculia wellingtonensis dilakukan dengan metode jaring pertumbuhannya lebih lambat (270 \%). Jenis yang lain Polymastia croceus ditransplantasi dengan metode tali, pertumbuhannya sekitar $360 \%$, dengan metode jaring 130\%, jenis Geodia cydonium dengan metode jaring $380 \%$, dan jenis lainnya kurang dari $150 \%$.

Total biomassa spons spons selama 1 tahun tranplantasi mencapai 5 kali lebih tinggi pada spons di ekosistem terumbu yang dekat pantai pada kedalaman yang sama daripada biomassa spons yang jauh dari pantai. Besarnya nutrien di ekosistem terumbu karang dekat pantai sangat mempengaruhi besarnya biomassa spons. Tingginya pertumbuhan spons pada konsentrasi nitrat dan fosfat yang tinggi diduga berhubungan dengan mikrosimbionnya. Nitrat dan fosfat secara bersama-sama dibutuhkan oleh mikrosimbion spons untuk pertumbuhannya. Mikroba simbiotik pada spons terdiri dari bakteri heterotropik, cyanobakteri dan alga uniseluler. Mikroba simbiotik pada jaringan spons dapat mencapai $60 \%$ dari volumenya. Peningkatan jumlah mikroba simbiotik pada jaringan dan sel transplan secara langsung atau tidak langsung, dapat mempercepat pertumbuhannya. Secara langsung peningkatan jumlah mikroba dapat menambah biomassa pada jaringan dan sel, sedangkan secara tidak langsung peningkatan jumlah mikroba simbiotik akan mempercepat laju metabolismenya yang ekresinya dipakai juga oleh induk semangnya.

Pengamatan spons terkait nutrisi atau makanan dan pertumbuhan spons Callyspongia vaginalis, Angelas conifera dan Aplysina fistularis dari Florida dan Bahama, terdapat perbedaan yang nyata lebih besar 
terhadap hasil transplantasi spons baik pada biomassa, pertumbuhan maupun makanan dengan semakin bertambahnya kedalaman. Percobaan yang dilakukan di kedalaman $7 \mathrm{~m} ; 15 \mathrm{~m} ; 23 \mathrm{~m}$ dan $30 \mathrm{~m}$, tersebut menunjukan bahwa pada semua stasiun pengamatan spons mengkonsumsi 65-93\% partikel bahan organik sebagai makanan. Pertumbuhan spons meningkat seiring dengan bertambahnya kedalaman, karena adanya peningkatan ketersediaan makanan dan terjadinya proses-proses di dasar perairan yang pada akhirnya mempengaruhi pertumbuhan spons. Makanan yang banyak dimakan spons adalah partikel organik karbon. Karibian spons seperti $C$. vaginalis, A. conifera dan A. fistularis mendapatkan makanan melalui proses heterotropik, hal ini tidak seperti tipe spons fotoautotropik yang terdapat di Great Barrier Reef. Spons P. nigricans termasuk spons heterotropik karena menyukai habitat perairan yang lebih dalam yang kaya bahan organik dan berdasarkan data kualitas air.

Khusus pada perairan dangkal dalam melakukan transplantasi spons perlu diperhatikan persaingan antara karang dan alga untuk melakukan fotosintesa. Pada perairan yang lebih dalam, spons mendapatkan energi yang lebih besar dari bertambahnya konsentrasi picoplankton. Di perairan dangkal, spons berkompetisi dengan alga dan karang untuk mendapat ruang dan cahaya, sehingga spons harus beradaptasi dengan perairan yang lebih dalam. Di perairan Barranglompo, spons Auletta sp, Callyspongia sp dan Halichondria sp menunjukan pertumbuhan lebih baik pada kedalaman 12 meter daripada pada kedalaman 3 meter. Gambar 9.6, memperlihatkan kelangsungan hidup spons yang ditransplantasi pada kedua pulau percobaan, yakni Pulau Pari dan Pulau Pramuka sekitas Kepulauan Seribu, Jakarta.

Cahaya dalam bentuk radiasi ultra violet (UV) adalah faktor pembatas di perairan dangkal dengan kedalaman kurang dari 10 meter. Kelangsungan hidup spons $P$. nigricans pada pada dua lokasi dan kedua kedalaman setelah 1 tahun transplantasi berkisar 90, 00-100, $00 \%$, ratarata kelangsungan hidup spons perairan Pulau Pari lebih tinggi dari pada perairan Pulau Pramuka dengan nilai pada lokasi Pulau Pari 7 meter (97, $23 \%)$, Pari 15 meter (100\%), Pramuka 7 meter (90, $56 \%$ ) dan Pramuka 15 meter $(94.17 \%)$. 


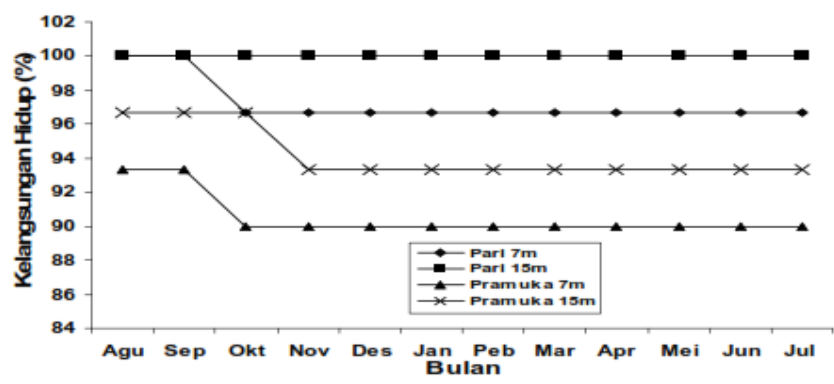

Gambar 9.7. Kelangsungan hidup (\%) spons di perairan Pulau Pari dan Pulau Pramuka pada kedalaman 7 meter dan 15 meter

Spons Callyspongia biru pada kedalaman 12-15 meter di Kepulauan Spermonde berkisar 82, 0-100, $0 \%$. Di alam kelangsungan hidup spons termasuk tinggi dan tergolong spons berukuran besar, serta mempunyai potensi besar untuk dibudidayakan sebagai bahan bioaktif. Kelangsungan hidup spons setelah memasuki bulan ke empat dan seterusnya, spons yang ditransplantasikan sudah mampu beradaptasi secara sempurna dan kemampuan pertahanan kimianya (chemical defense) juga sudah terbentuk dengan baik dalam merespon gangguan lingkungan. Pertahanan kimia yang diproduksi spons, juga memiliki peranan penting secara ekologi di alam untuk pertahanan terhadap faktor-faktor tekanan lingkungan, seperti antipredasi dan aktivitas antifouling, mencegah infeksi yang disebabkan oleh mikroorganisme patogenik dan berkompetisi ruang.

\section{3. Perlukah dilakukan Transplantasi Spons}

Spons yang banyak mengandung zat bioaktif sangat potensial untuk dikembangkan dalam menciptakan obat jenis tertentu, spons juga diketahui dapat berfungsi sebagai antibakteri, aktijamur, sert spons dengan cara hidup filter feeder, memberi peluang besar untuk dapat menyerap makanan yang potensial sebagai bahan yang akan terdekomposisi dalam tubuh spons untuk selanjutnya akan mengalami perubahan yang pada akhirnya dapat menghasilkan zat spesifik yang justru sangat dibutuhkan oleh manusia tertama dalam ilmu pengobatan. Kandungan senyawa kimia yang telah diidentifikasi dari berbagai jenis spons, menunjukkan bahwa sposn adalah salah satu bahan alam laut yang memegang peranan penting dalam berbagai bidang kehidupan teruma dalam dunia kesehatan, kecantikan, ilmu peracikan obat dan berbagai kepentingan lainnya. 
Seiring dengan perkembangan ilmu pengetahuan dan sangat bervariasinya kebutuhan masyarakat, mengakibatkan penelitian banyak dilakukan yang semuanya bermuara pada bagaimana pemenuhan kebutuhan hidup manusia bukan hanya pada sumber makanan, tetapi gaya hidup, penampilan dan usaha untuk mencari model-medel pemenuhan kebutuhan yang serba praktis, akibatnya penelitian banyak dilakukan di berbagai tempat untuk berlomba menghasilkan temuan-temuan baru yang spektakuler termasuk dalam riset mengenai spons. Walhasil usaha ini berhasil mengungkap bahwa spins juga dapat dijadikan sebagai bioindikator kualitas lingkungan laut terkait dengan pencemaran oleh material-material berbahaya seperti Poli Aromatik Hidokarbon (PAH) yang memiliki sifat karsinogenik (pemucu kanker) dan sifat mutagenik (pemicu aktifnya sel-sel kanker dalam tubuh), paparan logam berat dengan toksisitas tinggi seperti merkuri (Hg), Timbal (Pb), Arsen (As), Kromium (Cr), Kadmium (Cd) dan berbagai logam berat lainnya, tidak terkecuali oleh material golongan plastik, kaleng.

Pengetahuan tentang spons, biomassa spons dan mikrosimbion (mikroorganisme) yang berpotensi sebagai biomaterial yang dapat mendegradasi komponen hidrokarbon baru berkembangan dalam 2 dekade dewasa ini, dengan pemahaman bahwa kandungan karbon dalam komponen minyak bumi dapat diuraikan oleh jenis bakteri tertentu untuk selanjutnya dijadikan oleh bakteri tersebut sebagai sumber karbon untuk dikomversi dalam bentuk energi. Selanjutnya dipahami bahwa jenis spons tertentu dan mikrosimbionnya juga dapat menjalankan fungsi bioabsorpsi terhadap logam berat untuk tujuan reduksi sifat toksik logam berat justru baru ramai dibicarakan dalam satu decade belakangan ini. Prediksi bahwa terdapat mikroorganisme tertentu yang dapat menyambung keretakan pada beton dengan zat menyerupai enzim yang dapat diproduksi oleh suatu bakteri, dimana hampir pasti bahwa setiap jenis spons dapat bersimbiosis dengan satu atau beberapa jenis bakteri tertentu adalah sebuah keniscayaan dari prediksi di atas dapat ditemukan pada bakteri yang bersimbion dengan spons. Sebuah angan-angan bahwa bakteri berpotensi untuk menjadi bahan pencampur cat tembok yang bertujuan mengatasi keluhan masalah tumbuhnya lumut pada tembok yang dapat merusak estetika bangunan adalah suatu masalah tersendiri yang membutuhkan pemecahan. Kombinasi antara potensi spons dan 
mikrosimbionnya sebagai salah satu sumber biomaterial yang dapat mengatasi masalah-masalah tersebut di atas dengan merujuk pada acara hidup spons yang sangat unik, bukan tidak mungkin ditemukan suatu jenis bakteri spesifik yang merupakan simbion spons yang menjadi jawabannya.

Semua hal tersebut di atas menjadikan spons sebagai salah satu makhluk penting untuk populasinya dikembangankan atau paling tidak adanya keberpihakan terhadap budidaya spons, sehingga transplantasi spons merupakan salah satu upaya penting yang harus dilakukan sebagai upaya mempertahankan populasi spons agar dapat berkembang dengan pesat. Ungkapan-ungkapan tentang bagaimanakah cara dan pola hidup spons, apakah spons merupakan tumbuhan atau hewan, apakah spons merupakan makhluk tertua di kelasnya, kemampuan hidup spons sangat panjang, suguhan warna-warni dari spons, dan potensi wisata bawah laut dengan populasi spons didalamnya, menjadikan spons sebagai objek seksi untuk di geluti bukan hanya oleh para peneliti tetapi dapat merambah pada banyak profesi dan golomgan.

\section{4. Syarat dan Faktor-faktor yang Mempengaruhi Transplantasi Spons}

Beberapa hal yang perlu diperhatikan dalam melakukan transplantasi spons. Penentuan organisme uji hendaknya yang dipilih pada adalah spons dari jenis tertentu yang diperkirakan mudah beradaptasi dengan lingkungan baru, seperti jenis Stylotella aurantium dengan berdasarkan keadaan morfologi induk yang besar dan sehat serta berwarna cerah yaitu untuk menandakan bahwa induk tersebut sehat dan baik untuk dijadikan bibit spons transplantasi. Penyediaan wadah transplantasi spons adalah yang dapat melekat dengan baik pada substrat beton dan jaring. Wadah transplantasi yang dipilih yaitu substrat yang terbuat dari beton/batako yang berbentuk persegi panjang kemudian dibagi menjadi dua bagian bentuk persegi. Hal lain yang tidak kalah pentingnya terkait transplantasi spons adalah perawatan spons transplantasi, misalnya jenis (S. aurantium) yang ditransplantasi dilakukan dengan membersihkan spesimen beserta media dari gangguan alga yang tumbuh pada wadah transplantasi dan kotoran lain yang terbawa arus. Frekuensi pengontrolan terbagi atas tiga bagian yaitu minggu pertama sampai minggu kedua, 
minggu ketiga sampai minggu keempat, dan minggu kelima sampai selesai. Pada minggu pertama sampai minggu kedua pengontrolan dilakukan setiap hari, karena pada masa ini merupakan masa yang paling riskan kematian pada organisme transplantasi. Pengontrolan pada minggu ketiga sampai minggu keempat dilakukan dalam satu minggu satu kali, hal ini dikarenakan pada masa ini spons laut belum bisa mempertahankan diri sepenuhnya dari faktor lingkungan yang mengganggu karena masih melakukan proses penyembuhan luka potongan. Pada minggu kelima sampai selesai dilakukan pengontrolan 15 hari sekali karena pada masa ini spons laut sudah sembuh dari luka irisan dan mampu mempertahankan diri dari faktor lingkungan, pembersihan ini menggunakan kain atau sikat halus untuk menghindari spesimen terlepas dari substrat.

Beberapa faktor yang dapat mempengaruhi pertumbuhan transplantasi spons berupa faktor fisik, faktor kimia dan faktor biologi. Faktor fisik seperti:

1. Temperatur memberikan pengaruh terhadap spons untuk pertumbuhan pada kisaran suhu optimal $26-31^{\circ} \mathrm{C}$ dan di daerah empat musim suhu merupakan faktor lingkungan utama yang mengatur reproduksi spons, berkaitan dengan perubahan suhu yang mencolok pada tiap musimnya. Umumnya spons tidak mampu beradaptasi terhadap perubahan suhu yang sangat cepat, namum biasanya spons lebih beradaptasi dengan penurunan suhu dibandingkan peningkatan suhu.

2. Cahaya berpengaruh pada potensi simbion yang dapat terjadi, dimana misalnya sianobakteria banyak terdapat pada spons di daerah tropis. Bahan organik yang dihasilkan oleh endosimbion tersebut merupakan salah satu alternatif sumber makanan bagi spons. Hubungan antara endosimbion dan spons adalah dalam hal sumber makanan. Distribusi beberapa jenis spons juga tergantung pada intensitas cahaya. Penetrasi cahaya matahari yang optimum memicu pertumbuhan (pembelahan sel) dan metabolisme alga mikrosimbion. Metabolisme yang intensif menghasilkan buangan (sekresi) metabolis yang dapat dimanfaatkan kembali oleh inangnya (spons) untuk proses metabolism selanjutnya.Jika simbion berupa mikroalga dengan spons mengandung pigmen yang dapat melindungi permukaan spons dari kerusakan DNA akibat radiasi UV-B. 
3. Kekeruhan dan Sedimentasi yang tinggi dapat meningkatkan laju sedimentasi pada permukaan spons, memberi pengaruh nyata pada perkembangan spons. Keadaan ini memaksa spons mengeluarkan energi lebih banyak untuk menghalau sedimen dengan jalan memproduksi lendir dalam jumlah banyak. Produksi lendir yang banyak dapat membuat spons mati lemas, karena secara efektif mengisolasi spons sehingga menghambat pertukaran air. Sedimentasi yang tinggi dapat mematikan spons karena menutupi ostium dan oskulum. Sedimentasi yang tinggi menyokong perkembangan bakteri pada bagian tubuh yang terluka. Perairan yang jernih memberikan beberapa keuntungan. Pertama, mengurangi sekresi lendir yang dipergunakan untuk menghalau partikel-partikel yang mengendap dipermukaan tubuh akibat tingginya laju sedimentasi, sehingga menghemat energi yang dialokasikan untuk memproduksi lendir. Energi yang dihemat tersebut kemudian digunakan untuk tumbuh dan bereproduksi. Kedua, memperdalam penetrasi cahaya matahari yang masuk ke perairan. Spons sering kali menyaring partikel yang tidak penting seperti lumpur dan silt. keberadaan lumpur dan silt dapat menurunkan laju pemompaan air pada spons. Penurunan laju pemompaan berpengaruh pada menurunnya pengambilan makanan dan akhirnya penurunan metabolisme dan pertumbuhan menjadi lambat.

4. Arus dan Gelombang berperan sangat penting dalam proses penyediaan makanan bagi spons yang merupakan filter feeder. Arus bermanfaat untuk memindahkan nutrien, larva dan sedimen. Arus juga berguna untuk menghalau dan membersihkan sampah serta sedimen yang menutupi fragmen, sehingga spons dapat tumbuh lebih baik. Pergerakan massa air yang tinggi akan meningkatkan pertumbuhan spons, sedangkan energi gelombang yang besar dapat mengakibatkan spons yang rapuh akan hancur.

Faktor kimia yang mempengaruhi pertumbuhan dan perkembangan spons transplantasi seperti:

1. Salinitas Air laut memiliki salinitas rata-rata 35 permil. Meskipun organisme laut mampu beradaptasi dengan kondisi tersebut, namun perubahan salinitas dengan cepat dapat mempengaruhi sistem osmoregulasi. Bagaimanapun organisme yang hidup di daerah estuari 
atau daerah dangkal dapat beradaptasi dengan perubahan tersebut, sebagian besar hewan laut lain termasuk spons sangat sensitif dengan perubahan salinitas. Mac Millan (1996) menyatakan, budidaya spons tidak dapat dilakukan di laut yang dekat dengan sungai atau danau karena air tawar dan payau dapat membunuh spons. Spons hidup pada salinitas 28 - $38 \%$, dan lebih sensitif terhadap salinitas yang rendah. Berdasarkan pengamatan oleh para peneliti ditmukan adanya penurunan salinitas sangat membahayakan pertumbuhan spons.

2. Oksigen terlarut (DO) dan udara bebas oksigen terlarut erat kaitannya dengan jumlah bahan organik yang berada di suatu perairan. Kandungan DO menurun dengan masuknya bahan organik ke perairan, karena dimanfaatkan oleh organisme untuk diuraikan. Kebutuhan spons terhadap oksigen per sentimeter kubik volume spons bervariasi antara 0, 2 - 25 Spons $\mu$ mol $\mathrm{O}_{2}$ per jam. Spons tidak boleh terpapar udara langsung karena memungkinkan udara masuk ke dalam sistem kanal, merusak koanosit dan menutup sistem saluran spons. Banyak spons yang mati setelah terekspos udara walaupun hanya dalam waktu singkat. Namun, udara yang telah masuk ke dalam kanal/ saluran dapat dibuang dengan menggoyangkan spons di dalam air.

3. Berbeda dengan spons yang hidup di daerah intertidal, jenis - jenis ini memiliki toleransi tinggi terhadap kondisi tersebut menunjukkan bahwa spons memproduksi slime pada permukaan tubuh untuk menjaganya tetap dalam kondisi basah atau dengan menutup ostia atau bahkan melakukan kedua mekanisme tersebut.

4. Ketersediaan silikat dan senyawa bioaktif spons sangat dibutuhkan oleh spons untuk membentuk rangka tubuhnya. Spons tidak dapat berdiri tegak tanpa adanya spikul atau spongin yang membentuk kerangka penopang tubuh sehingga memungkinkan adanya saluran dan ruangan berflagela. Skeleton spons kelas Demospongiae dan Hexactinellida tersusun dari kerangka yang mengandung silika yang disebut spikul yang disekresi oleh sel khusus yang disebut sclerocyts. Bahan silikon diambil oleh sel-sel tersebut dari perairan dalam bentuk asam salisilat dan didepositkan di sekitar proteinaceous filament. Racun secara alami dapat dijumpai sebagai senyawa bioaktif yang diproduksi spons. Senyawa bioaktif tersebut dapat berfungsi sebagai 
pertahanan dari predator, mencegah penempelan organisme lain, bahkan sebagai media komunikasi antar spons.

Faktor biologis yang berpengaruh terhadap pertumbuhan dan perkembangan spons terdiri atas:

1. Penyakit pada spons. Penyakit pada spons memberikan pengaruh yang cukup besar bagi populasi spons, baik di alam maupun budidaya. Kematian spons massal spons pernah terjadi 1938-1939 dan 19471948 yang terjadi terhadap spons yang ada di Mexico. Kematian ini disebabkan karena penyakit yang menyerang. Peningkatan temperatur diduga berpengaruh terhadap peningkatan patogen. Pada tahun 19861990 di Mediterania ditemukan kasus penyakit pada populasi spons yang terdapat di periran yang paling hangat. Kejadian ini memberikan kesimpulan bahwa ada hubungan antara pemanasan global dengan perkembangan penyakit pada organisme laut termasuk spons.

2. Pemangsaan spons umumnya dianggap dapat terlindung dari predator. Keberadaan kerangka spikul pada spons membuat spons tidak cukup menarik untuk dimangsa. Selain itu, spons juga memproduksi senyawa kimia sebagai perlindungan diri. Meskipun demikian, pemangsa spons tetap ada. Beberapa organisme laut, misalnya Nudibranch diketahui sebagai pemangsa spons yang dapat mengakumulasi senyawa kimia dari spons untuk melindungi diri dari predator.

3. Beberapa vertebrata seperti ikan karang jenis Holacanthus bermudensis, H. tricolor, Pomacanthus arcuatus, Lactophrys quadricornis, Cantherhines pullus, Sparisoma aurofrenatum dan S. chrysopterum diketahui merupakan predator spons jenis Chondrosia coIlectrix dan Geodia tibberosa di Great Barrier Reef.

Teknik pengamatan berupa pengukuran dan pengambilan data pengukuran pertumbuhan bibit dilakukan setiap 15 hari selama 90 hari penelitian agar perkembangan spons terlihat nyata dan dapat terukur, pengukuran menggunakan jangka sorong (kaliper ketelitian 0,01 mm). Parameter yang diukur adalah panjang, tinggi dan lebar spons (volume) karena S. aurantium mempunyai bentuk pertumbuhan menyerupai gumpalan tidak beraturan. Variabel yang umum diamati terkait dengan transplantasi spons adalah pertumbuhan mutlak (PM), Laju Pertumbuhan Spesifik (LPS), Sintasan (SR), morfologi dan kualitas air adalah bagian 
yang harus menjadi perhatian dalam melakukan pengamatan tentang transplantasi spons.

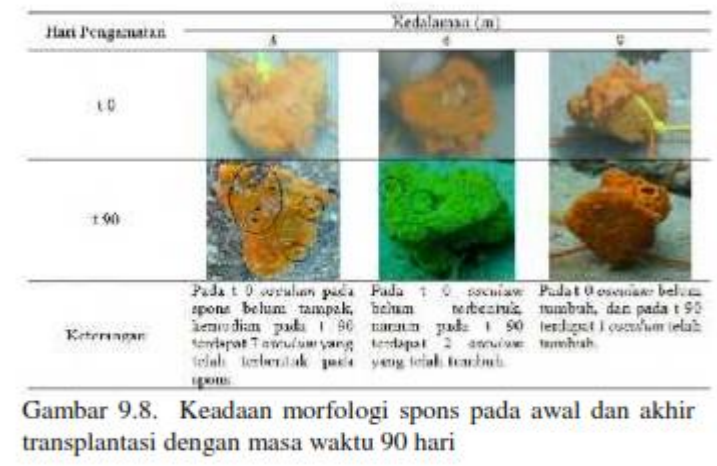

Pada penurunan awal morfologi spons terlihat hasil irisan yang rata pada badan spons, kemudian pada hari ke 15 sudah terdapat sebuah osculum yang tumbuh di badan spons. Pada pengamatan hari ke 30 osculum yang tumbuh bertambah banyak jumlahnya. Kejadian ini berlanjut seiring dengan makin bertambahnya hari maka semakin bertambah pula jumlah osculum yang tumbuh pada badan spons. Hal ini di perkuat dengan pemahaman bahwa proses perubahan morfologi spons di atas mengindikasikan bahwa spons yang mempunyai osculum, maka spons tersebut dapat dikatakan tumbuh dan berkembang karena osculum berfungsi sebagai saluran pencernaan dimana osculum merupakan tempat pembuangan hasil sisa makanan spons. Parameter kualitas air yang diukur selama percobaan berlangsung meliputi suhu, kadar garam (salinitas), kecerahan dan kecepatan arus, adapun hasilnya dapat dilihat pada Tabel 9. 2, berikut:

\begin{tabular}{|c|c|c|c|c|c|c|}
\hline \multirow{2}{*}{ Non. } & \multirow{2}{*}{ Parameter } & \multirow{2}{*}{ Sutan } & \multicolumn{4}{|c|}{ Waitu Peagaratan (Tlar be) } \\
\hline & & & to & t30 & 100 & 190 \\
\hline 1 & Sulu & ("L) & 28 & 28 & 17 & 27 \\
\hline 2 & Siliritas & (bet) & H & $n 2$ & 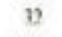 & $x$ \\
\hline 1 & Keecrahar & $(6)$ & $\mid m i$ & $10 \%$ & $100 \%$ & $10 r_{i}$ \\
\hline 1 & Kce Ans & (nílen) & Q.111 & Q ales & 0.121 & 0.127 \\
\hline
\end{tabular}

Pertumbuhan spons transplantasi dapat dilihat pada adanya perlekatan pada suatu substrat, menunjukkan spons tersebut tidak berpindah tempat lagi dan pada substrat tersebut spons tumbuh. Spons laut 
S. aurantium yang ditransplantasi pada kedalaman berbeda dikelompokan berdasarkan perlakuan kedalaman. Perlakuan A ditempatkan pada kedalaman $3 \mathrm{~m}$ sedangkan pada perlakuan B ditempatkan pada kedalaman $6 \mathrm{~m}$, dan perlakuan $\mathrm{C}$ ditempatkan pada kedalaman $9 \mathrm{~m}$. Kedalaman menunjukkan bahwa secara morfometrik dan morfologi memperlihatkan adanya perbedaan yang nyata terhadap pertumbuhan spons $\mathrm{S}$. aurantium (P > 0, 05), hal ini dapat didefenisikan bahwa ketiga kedalaman tersebut mempengaruhi pertumbuhan mutlak, laju pertumbuhan spesifik, tingkat kelangsungan hidup dan keadaan morfologi spons S. aurantium yang ditransplantasi dengan kedalaman yang berbeda. Pengamatan secara statistik menunjukan pertumbuhan mutlak yang berbeda dari masingmasing kedalaman, rata - rata pertumbuhan mutlak terbaik terdapat pada kedalaman $3 \mathrm{~m}$ dengan total nilai rata - rata pertumbuhan mutlak 46,721 $\mathrm{cm}^{3}$, sedangkan pada urutan kedua yaitu pada kedalaman $6 \mathrm{~m}$ dengan total nilai rata - rata pertumbuhan adalah $33,917 \mathrm{~cm}^{3}$, serta urutan terendah teredapat pada kedalaman $9 \mathrm{~m}$ dengan total nilai rata - rata pertumbuhan mutlak hanya mencapai $18,306 \mathrm{~cm}^{3}$.

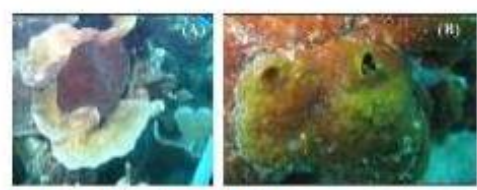

Gambar 9.9. Pertumbuhan spons laut (A) Petrosia sp dan (B) Aaptos aaptos di habitat alami

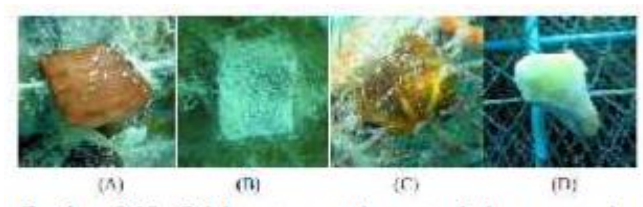

Gambar 9.10. Salah satu contoh pertumbuhan spons laut transplantasi (A), (B) Petrosia sp dan (C), (D) Aaptos aaptos di habitat alami

Hal ini diduga bahwa kedalaman masih mempengaruhi tingkat pertumbuhan spons dimana spons masih memerlukan intensitas cahaya untuk tumbuh dan berkembang. Selain memerlukan intensitas cahaya yang cukup, spons juga memerlukan makanan yang terbawa oleh arus laut untuk dapat tumbuh dan berkembang. Penetrasi cahaya matahari yang optimum memicu pertumbuhan (pembelahan sel) dan metabolisme alga mikrosimbion. Metabolisme yang intensif, dapat menghasilkan buangan (sekresi) metabolis yang dapat dimanfaatkan kembali oleh inangnya (spons) untuk proses metabolism. Gambar di atas berturut-turut 9.9; 9.10, memperlihatkan bahwa ada perbedaan nyata spons yang hidup di alam habitat alami dengan spons transplantasi yang sengaja dikembangkan pada daerah tertentu, namun setelah beberapa lama spons transplantasi akan mampu beradaptasi sehingga pada waktu tertentu akan terlihat seperti 
induknya, sebagaimana terlihat pada Gambar 9.11 di bawah. Mikroalga simbion spons mengandung pigmen yang bisa melindungi permukaan spons dari kerusakan DNA akibat radiasi UV-B.menunjukkan bahwa dengan tercapainya beberapa kebutuhan spons untuk hidup maka pertumbuhan spons akan berjalan baik, hal ini dapat diketahui dengan melihat hasil perhitungan laju pertumbuhan spesifik (LPS) spons yang ditransplantasi pada kedalaman berbeda yaitu pada kedalaman $3 \mathrm{~m}$ dengan total rata - rata laju pertumbuhannya adalah $1,363 \%$, pada

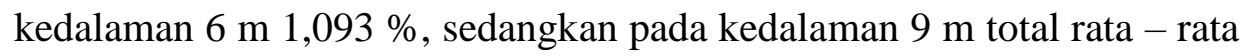
laju pertumbuhannya yaitu $0,748 \%$. Dengan melihat hasil perhitungan pertumbuhan spons $\mathrm{S}$. aurantium di atas.

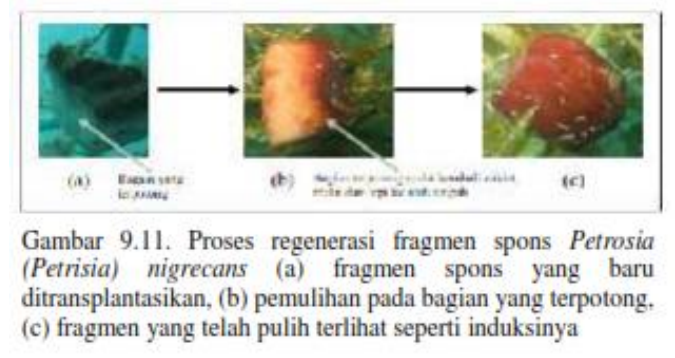

Pertumbuhan terbaik untuk transplantasi spons berdasarkan kedalaman, yakni kedalaman $3 \mathrm{~m}$. Kedalaman ini menunjukkan spons masih bisa mendapatkan makanan dan intensitas cahaya serta oksigen yang banyak sehingga spons dapat tumbuh serta berkembang dengan baik. Kecerahan merupakan faktor pembatas dalam menentukan sumber energi dan memberikan masukan bahan makanan bagi kehidupan organisme yang berada pada ekosistem terumbu karang. Spons laut menyukai lingkungan perairan yang jernih, dimana cahaya matahari bisa menembus dasar perairan yang dibutuhkan oleh spons. Selain cahaya yang cukup, arus juga sangat berpengaruh terhadap pertumbuhan organisme laut khususnya pada spons. Arus yang baik dapat memberikan makanan untuk spons sebab pola makan spons hanya mengharapkan dari besaran masuknya kadar air ke dalam tubuh spons agar spons dapat menyaring bahan makanan yang terkandung dalam perairan. Hal ini berkaitan dengan keadaan dimana spons memperoleh makananya dengan menyaring partikel-pertikel makanan yang terbawa arus melewati tubuhnya. 
Makanan diperoleh dengan mengalirkan air melalui ostia (ostium) ke dalam spongiosel.

Arus berperan sangat penting dalam proses penyediaan makanan bagi spons yang merupakan filter feeder. Arus bermanfaat untuk memindahkan nutrien, larva dan sedimen. Arus juga berguna untuk menghalau dan membersihkan sampah serta sedimen yang menutupi fragmen sehingga spons dapat tumbuh lebih baik. Selanjutnya, salah satu faktor yang mempengaruhi pertumbuhan spons adalah suhu perairan. Kisaran suhu yang didapatkan pada area transplantasi yaitu pada kisaran $27-28{ }^{\circ} \mathrm{C}$. Kisaran suhu ini sangat cocok untuk pertumbuhan spons laut. Kisaran suhu yang layak bagi lingkungan hidup spons laut berkisar antara $24-30{ }^{\circ} \mathrm{C}$, kurang dari $24{ }^{\circ} \mathrm{C}$ akan menyebabkan tingkat kelangsungan hidup (survival rate) dan pertumbuhan spons laut terganggu, sedangkan suhu yang optimal untuk pertumbuhan spons laut berkisar antara $28{ }^{\circ} \mathrm{C}$ dan suhu maksimal $30{ }^{\circ} \mathrm{C}$. Suhu merupakan salah satu faktor lingkungan yang penting bagi kehidupan dan penyebaran organisme. Suhu mempengaruhi baik aktivitas metabolisme maupun perkembangbiakan dari organisme perairan. Sebaran salinitas yang terukur pada lokasi transplantasi dimana pengukuran salinitas dilakukan 4 kali yaitu pada awal eksperimen t-0, t-30, t-60 dan t-90 menunjukkan variasi yang seragam dengan salinitas 31-33 ppt.

Pengaruh air tawar berdampak pada pertumbuhan spons transplantasi, adanya muara sungai yang dapat mempengaruhi nilai salinitas pada kondisi perairan, selain itu kondisi cuaca yang stabil dimana curah hujan yang stabil sehingga pengenceran air laut yang dapat merubah nilai salinitas tidak terjadi nilai salinitas pada lokasi penelitian ini mendukung pertumbuhan spons laut $\mathrm{S}$. aurantium yang ditransplantasi. Perubahan salinitas dapat mempengaruhi sifat-sifat fungsional dan struktur organisme laut melalui perubahan osmosa, konsentrasi perimbangan cairan, koefisien absorbsi dan kejernihan gas-gas terlarut. Spons dapat mentolerir salinitas minimal 22 ppt dan salinitas optimum berkisar antara $30-33$ ppt serta batas maksimal salinitas air laut yang dapat ditolerir untuk kehidupan spons laut sekitar 34 ppt. Meskipun organisme laut mampu beradaptasi dengan kondisi tersebut, namun perubahan salinitas dengan cepat dapat mempengaruhi sistem osmoregulasi. Bagaimanapun organisme yang hidup di daerah estuari 
atau daerah dangkal dapat beradaptasi dengan perubahan tersebut, sebagian besar hewan laut lain termasuk spons sangat sensitif dengan perubahan salinitas. Spons tidak dapat dilakukan di laut yang dekat dengan sungai atau danau karena air tawar dan payau dapat membunuh spons. Penurunan salinitas sangat membahayakan spons. Terpenuhinya kebutuhan spons terhadap kualitas perairan, maka spons dapat tumbuh dengan baik. Spons khususnya S. aurantium dapat dikatakan tumbuh baik apabila pada badan spons terdapat saluran pembuangan yang dinamakan osculum.

\section{5. Jenis dan Peluang Keberhasilan Transplantasi pada Material Laut}

Transplantasi terhadap bahan alam laut seperti spons dan karang dapat dilakukan dengan bebrbagai tujuan dan kepentingan baik yang sifatnya hanya untuk kepentingan riset maupun untuk tujuan perluasan karang dan perbanyakan populasi spons, meningkatkan kepedulian terhadap status terumbu karang sampai pada transplantasi untuk tujuan pengolahan perikanan. Kriteria penilaian keberhasilan transplantasi karang secara umum dikatakan berhasil apabila transplantasi tersebut dapat mencapai tujuannya, dan tidak merusak habitat terumbu karang dan ekosistemnya. Maka kriteria penilaian keberhasilan adalah sebagai berikut:

1. Prosedur transplantasi harus sesuai dengan prosedur yang telah ditetapkan

2. Tidak merusak kondisi terumbu karang tempat pengambilan bibit (dapat dipantau)

3. Tujuan transplantasi dapat dicapai dengan baik

4. Transplantasi karang dapat dilaksanakan oleh masyarakat nelayan

5. Area transplantasi harus yang memiliki arus dan gelombang sedang

6. Lokasi budidaya spons relatif tidak bersedimentasi

\section{5. 1. Tujuan Transplantasi Bahan Alam Laut}

a. Transplantasi untuk tujuan perluasan terumbu karang

Perluasan terumbu karang dapat diartikan sebagai suatu usaha untuk membuat habitat terumbu karang baru, atau merubah habiat lain diluar habitat terumbu karang menjadi habitat terumbu karang. Di kawasan ekosistem terumbu karang sendiri, tidak semua dasar lautnya 
merupakan habitat terumbu karang. Bagian-bagian dasar laut yang bukan habitat terumbu karang itu, mungkin karena di tempat itu ombaknya terlalu besar, karena banyaknya endapan, karena arus yang terlalu kencang, karena kedalamannya yang melebihi batas kedalaman karang hidup, atau karena banyaknya kegiatan manusi. Maka trasplantasi karang untuk tujuan perluasan terumbu karang di ekosistem terumbu karang, perlu memperhatikan faktor-faktor penyebab tidak adanya kehidupan karang di tempat tersebu, kemudian merencanakan suatu model substrat buatan yang dapat meniadakan pengaruh faktor penyebab tersebut.

Perluasan terumbu karang dapat dilakukan di rataan terumbu ( reef flat) yang pada waktu air surut rendah masih tergenang air setinggi 0.5 meter, di tempat-tempat yang berdekatan dengan desa pesisir untuk meningkatkan kepedulian akan status terumbu karang, meningkatkan rasa memiliki dan meningkatkan kesadaran untuk melindungi sumberdaya terumbu karang; dan di sekitar fasilitas wisata untuk meningkatkan daya tarik objek pariwisata. Sedangkan persyaratan teknik pengambilan bibit dan tempat pengambilan bibit seperti dengan persyaratan pada butir satu di atas.

\section{b. Transplantasi karang untuk tujuan pariwisata.}

Transplantasi karang untuk tujuan wisata, dibedakan dari transplantasi karang untuk tujuan perluasan terumbu karang, karena kawasan wisata tidak selalu merupakan kawasan ekosistem terumbu karang, tetapi biasanya mempunyai laut yang tenang dengan perairan jernih dan tidak membahayakan bagi wisatawan yang ingin mandi di laut. Tidak adanya terumbu karang di kawasan ini mungkin disebabkan oleh karena tidak adanya substrat dasar yang keras tempat menempel larva karang. Beberapa tujuan utama transplantasi karang adalah: 1) membuat habitat terumbu karang yang kaya keaneka ragaman hayatinya; 2) membuat panorama yang indah didasar laut seperti halnya di ekosistem terumbu karang. Karang yang ditransplantasikan atau dipindahkan di lokasi tersebut, harus terdiri dari jenis-jenis karang yang beraneka ragam bentuk dan warnanya, sehingga ketika berkembang, dapat menghasilkan bentuk dan warna yang unik dan menarik. Substrat dasar buatan yang pakai harus menggambarkan bentuk dasar yang menarik dan tahan terhadap arus dan air laut, (permanen). Pemrakarsa transplantasi karang 
harus membuat peta lokasi trasplantasi karang menurut kelompok/jenis karang yang ditransplantasikan, beserta kedalamannya. (Peta ini untuk menjelaskan karang jenis tertentu yang di transplantasikan, lokasi). Peta ini penting baik untuk wisatanya maupun untuk pemantauannya. Persyaratan tempat pengambilan bibit dan teknik pengambilan bibit haeus diperhatikan untuk mendapatkan pertumbuhan yang memiliki panorama indah dan menarik bagi wisatawan.

c. Transplantasi untuk tujuan meningkatkan, kepedulian dan tertarikan jenis Terumbu karang

Rasa memiliki atau meningkatkan rasa memiliki dan kesiapan untuk melindungi sumber daya terumbu karang. Transplantasi karang jenis ini sebaiknya dilakukan oleh masyarakat nelayan yang sudah menyadari dampak negatif yang dideritanya akibat rusaknya terumbu karang di sekitarnya. Pelaksanaan transplantasi karang harus dilakukan sebaik -baiknya, karenanya para nelayan harus memperoleh latihan tentang teknik transplantasi karang secara lengkap, dengan penjelasan mengapa teknik tersebut harus dilakukan, termasuk penentuan lokasi pembibitan, cara pengambilan bibit dari induknya, cara pengangkutan bibit, cara penempelan bibit pada substratnya dan selanjutnya cara pemeliharaannya). Masyarakat nelayan harus didorong untuk memiliki rasa peduli status terumbu karang, tentunya transplantasi dilakukan secara bertahap sehingga pada waktu tertentu transplantasi dilakukan secara bertruktur sampai semua terumbu karang yang telah rusak itu pulih kembali. Perawatan untuk menjaga keutuhan hasil transplantasi karang itu, masyarakat nelayan dapat merasakan hasilnya. Karena dengan pulihnya kondisi terumbu karang, hewan laut termasuk ikan-ikan jenis tertentu juga bertambah banyak, dengan demikian diharapkan masyarakat nelayan semakin peduli dengan kelestarian terumbu karang karena manfaat dari pertumbuhan trumbu karang yang baik memiliki manfaat yang luar biasa bagi perekonomian masyarakat nelayan disekitarnya.

d. Transplantasi karang untuk tujuan pengelolaan perikanan

Peningkatkan produksi perikanan menjadi kebutuhan dan dambaan bukan hanya para nelayan tetapi juga pemerintah daerah dan pusat serta para pelaku perikanan terkait lainnya. Transplantasi karang dapat 
dilakukan di lokasi yang miskin ikan, dengan harapan adanya transplantasi karang tersebut dapat mendatangkan banyak ikan, dapat merubah habitat yang bukan habitat terumbu karang menjadi habitat terumbu karang. Pencapaian hal tersebut diperlukan substrat dasar yang tahan lama, tidak tererosi air laut, dan dapat ditempeli larva karang. Konstruksi substrat dasar tersebut harus dibuat sedemikian rupa sehingga tersedia ronggarongga yang dapat digunakan untuk berlindungnya ikan-ikan besar. Konstruksi substrat dasar seperti itu, berdampak pada terjadinya pertumbuhan karang hasil transplantasi akan menjadi lebih cepat karena hasil perkembang-biakan karang secara generatif dapat langsung menempel pada substrat dasar tadi, diikuti penempelan biota laut lainnya. Transplantasi karang seperti ini dapat menjadi atraksi untuk wisatawan atau untuk daerah perikanan baru bagi masyarakat nelayan. Persyaratan tempat pengambilan bibit dan teknik pengambilan bibit dilakukan selektif.

e. Terumbu karang buatan.

Istilah terumbu karang buatan yang sekarang ini berkembang di Indonesia, adalah murni Fish Aggregation Device (FAD), yaitu salah satu cara yang digunakan untuk merubah suatu perairan yang sepi ikan menjadi perairan yang banyak ikan. Disini tidak dipersoalkan apakah konstruksi yang dibuat itu dapat ditumbuhi karang atau tidak. Yang penting dengan konstruksi yang diletakkan di dasar laut dapat menyebabkan berkumpulnya ikan di sekitar konstruksi tersebut. Terumbu karang buatan untuk meningkatkan produksi perikanan, banyak terbuat dari ban mobil bekas yang disusun demikian rupa sehingga dapat menjadi pelindung ikan-ikan yang biasa berlalu lalang di perairan tersebut. Terumbu karang buatan seperti itu, sudah jelas tidak untuk menumbuhkan karang, karena larva karang rupanya tidak dapat menempel pada ban mobil. Terumbu karang buatan seperti ini seharunya tidak diletakkan di kawasan terumbu karang; pertama karena di kawasan terumbu karang biasanya sudah kaya berbagai jenis ikan, kedua karena dikhawatirkan bahan konstruksi terumbu karang buatan itu dapat mencemari ekosistem terumbu karang. Dimasukkannya terumbu karang buatan didalam pengelolaan ekosistem terumbu karang, adalah sebagai salah satu upaya meniadakan/ mengurangi penangkapan ikan di terumbu karang. Maka terumbu karang buatan dibangun di sekitar terumbu karang, sehingga nelayan tidak lagi 
menangkap ikan di terumbu karang, tetapi berpindah di terumbu karang buatan. Terumbu karang buatan itu dapat diletakkan di tengah-tengah jarak antara tempat tinggal nelayan dan terumbu karang, pada kedalaman tidak lebih dari 15 meter supaya mudah dipantau, sekaligus dapat berfungsi sebagai penghalang kapal pukat harimau yang sering menimbulkan konflik dengan nelayan tradisional.

\section{f. Transplantasi karang untuk tujuan penelitian}

Transplantasi untuk tujuan penelitian, biasanya dilakukan oleh peneliti terumbu karang atau oleh mahasiswa dibawah bimbingan seorang peneliti senior yang sudah mempunyai pemahaman secara mendalam mengenai bagaimana melaksanakan transplantasi tanpa merusak lingkungan ekosistem terumbu karang, apapun tujuannya. Dibedakan dari persyaratan yang harus dilakukan oleh pelaksana keenam transplantasi diatas, transplantasi untuk tujuan penenitian ini diberbolehkan mengambil bibit di sekitar lokasi penelitian, dengan teknik pemotongan cabang di tempat, tanpa memindahkan induknya. Karena transplantasi untuk tujuan penelitian biasanya tidak memerlukan banyak specimen, dan dengan biaya dan waktu sangat terbatas.

\section{5. 2. Lokasi dan Metode Pelaksanaan Transplantasi Karang}

Lokasi pelaksanaan transplantasi karang umumnya dapat dilakukan di laut terbuka dengan beberapa kondisi, seperti kedalam, arus laut, pencahayaan matahari, salinitas dan nutrisi. Metode pelaksanaan transplantasi karang dilakukan dengan prosedur sebagai berikut: 1) pemilihan lokasi dengan kedalaman dasar laut berkisar 5-6 m; 2) peralatan kerja seperti tang aluminium untuk memotong-motong cabang; 3) hasil potongan dibawa ke daratan untuk ditumbuhkan di dalam mangkuk berisi semen; 4) potongan-potongan karang dibersihkan dari lendir dalam bak berukuran sedang, misalnya $10 \mathrm{~m}$ x $1 \mathrm{~m}$ x $50 \mathrm{~cm}$; 5) setiap potongan ditancapkan di dalam mangkuk terbuat dari campuran semen dan pasir dengan perbandingan 1:4. 5) perekat dipakai semen, kemudian karang yang akan ditumbuhkan itu didiamkan dalam bak air laut bersalinitas 33 ppt selama 2-3 hari; 6) potongan karang diletakkan di mangkuk-mangkuk berisi potongan karang dalam anjang-anjang yang terbuat dari kayu meranti, agar kuat, tiap mangkuk dilekatkan ke tali senar 
yang terpasang di kanan kiri baris anjang-anjang; 7) anjang-anjang lantas dipindahkan ke laut dan diletakkan dalam meja persegi panjang berpondasi beton. Pertumbuhan karang dapat terlihat biasanya setelah 3 bulan ke atas ditandai dengan lapisan kerak itu bermunculan polip-polip yang membentuk cabang karang baru. Seiring dengan pertambahan waktu transplantasi dalam waktu 7 bulan, karang sudah membentuk lebih dari 4 cabang dan siap dipanen.

Karang yang dilepas ke alam ditaruh di dalam beton berukuran 40 $\mathrm{cm}$ x $40 \mathrm{~cm}$. Letaknya berdekatan dengan karang yang tumbuh di alam. Keberhasilan mencangkok bukan berarti tanpa kematian. Sebanyak 20\% karang mati disebabkan karena serangan predator (hama) dan sedimentasi yang menyerang saat karang transplantasi dipindahkan ke laut. Hama yang kerap mengganggu adalah Achantastrea plantii. Keluarga karang yang memiliki ratusan kaki itu memakan jaringan karang di dekatnya. Achantastrea itu biasanya bermunculan ketika bahan organik dan populasi karang padat. Serangan achantastrea meruapakan ancaman serius terhadap keberhasilan transplantasi. Jumlah achantastrea yang melimpah mampu mematikan semua karang transplantasi dalam waktu sehari. Predator lainnya terhadap karang transplantasi adalah predator pinthaster yang berbentuk seperti bola. Hama ini seperti ganasnya dengan achantastrea yang memakan polip karang. Selain jenis karang lain yang menjadi predator, alga pun mengganggu kehidupan karang. Contohnya alga ulfa dan spadina yang muncul setiap bulan tertentu merupakan ancaman terhadap budidaya karang. Alga ulfa dan spadina merusak karang/ polip transplantasi dengan menempel di substrat lalu menjalar sampai ke polip. Akibatnya tubuh karang tertutup dan tak dapat menyerap matahari.

Sedimentasi dapat menjadi ancaman serius terhadap keberhasilan transplantasi karang. Sedimentasi dapat terjadi, biasanya disebabkan oleh kesalahan dalam memili lokasi pertumbuhan budidaya karang. Lumpur dapat menyebar umumnya disebabkan karena arus dasar laut lokasi transplantasi demikian pula pada saat peletakan anjang-anjang yang tidak tepat menjadi ancaman serius keberhasilan tranplantasi. Namun demikian, jika arus kurang, maka alga yang menjadi makanan karang menjadi sedikit. Selain arus, sedimentasi menjadi ancaman lain ketika salah meletakkan anjang-anjang. Saat upwelling (arus dari dasar laut naik ke atas), mengakibatkan materi lumpur dan pasir terseret ombak. Air laut 
menjadi keruh, materi lumpur dapat menutupi polip, dan sinar matahari tidak dapat diserap. Akibatnya biota mati. Dalam kondisi demikian, transplantasi karang mengalami kegagalan. Kekeruhan air dapat diukur dengan memakai tutup kaleng yang dicat hitam atau putih. Warna apa saja bisa asal kontras dengan warna laut, artinya sinar matahari tidak dapat diserap zooxanthellae karena terhalang oleh materi-materi sedimentasi. Mengatasi hal tersebut dapat dilakukan dengan merelokasi anjang-anjang ketempat lain yang dinilai lebih aman dari kemumngkinan adanya pergerakan lumpur.

Beberapa hal yang harus diperhatikan dalam menempatkan anjanganjang budidaya karang, seperti:

1 Arus sedang cocok untuk karang-karang dangkal seperti jenis-jenis yang sering dibudidayakan untuk tujuan komersil.

2 Lokasi harus datar agar anjanganjang kuat saat diterjang arus. Hal lain, tempat anjang-anjang harus terhindar dari terjangan angin barat atau timur.

3 Lokasi harus mendapat penyinaran yang cukup

4 Menjaga agar karang transplantasi terhindar dari alga pathogen; dan hama lainnya seperti Achantastrea.

Pemanenan karang transplantasi biasanya sudah dapat dilakukan setelah budidaya tersebut telah berlangsung dalam waktu minimal 7 bulan yang ditandai dengan bermunculannya polip-polip kecil. Panen terumbu karang hasil transplantasi dilakukan dengan cara mengangkat anjanganjang ke daratan, lalu diletakkan dalam bak $10 \mathrm{~m}$ x $1 \mathrm{~m}$ x $50 \mathrm{~cm}$. Sebelum dikemas, substrat yang tertutup lumut dan alga digosok. Setelah bersih, dasar substrat diikatkan ke gabus agar mengapung saat dimasukkan ke dalam kantong plastik berisi air hasil aerasi dengan skimmer. Oksigen ditambahkan ke dalam kantong plastik agar karang dapat bertahan hingga 48 jam perjalanan. Setelah itu plastik diikat dan dimasukkan dalam boks sedang biasanya berkapasitas 15 kantong yang diberi lubang di kanankirinya. Supaya tetap segar, di atas plastik diberi bongkahan es lalu ditutup selembar plastik. Boks styrofoam itu dimasukkan dalam boks karton berlapis plastik. Karang-karang hasil budidaya ini siap dipasarkan atau dikirim ke daerah/ Negara tujuan.

Potensi pasar karang hasil budidaya dengan motip berpolip kecil umumnya dapat dipasarkan dengan baik bahkan pasar luar negeri terkait 
dengan hasil budidaya trumbu karang seperti diekspor ke Eropa (Belanda, Jerman, Perancis, Italia, dan Spanyol), Amerika Serikat, dan Asia (Hongkong, China, Singapura, dan Arab). Adanya transplantasi membuat ketersediaan karang melimpah dan tidak habis meski diekspor. Dampaknya, kehidupan terumbu karang tetap berlangsung harmonis. Umumnya jenis karang yang ditransplantasi adalah jenis small polyp stony (karang batu berpolip kecil), seperti genus acropora, montipora, pocillopora, dan hydnopora, karena jenis ini memiliki pertumbuhan cepat dengan keberhasilan pertumbuhan bisa mencapai 90\%. Jeniskarang di atas memiliki pertumbuhan cepat, terutama yang berbentuk cabang dan foliosa (daun). Jenis lainnya, yakni large polyp stony yang kebanyakan berbentuk massive (keras) dan submassive.

Transplantasi karang tidak hanya dapat dilakukan di laut terbuka, tetapi juga dapat dilakukan dalam akurium. Transplantasi karang di akuarium relatif mirif dengan yang dilakukan pada lokasi tersebuka, bahkan cenderung lebih sederhana karena arus, sedimentasi, kualitas air termasuk salinitas dan serangan predator lebih terkontrol dengan baik. Cara melakukannya adalah yongei dilekatkan dalam substrat campuran pasir dan semen, kemudian ditata dalam anjang-anjang. Anjang-anjang tidak perlu dibawa ke laut, melainkan tetap dalam akuarium. Agar sesuai dengan kondisi di laut, air yang dipakai bersalinitas pada kisaran 30 - 34 ppt. Ketika salinitas naik karena terjadi penguapan, maka dapat ditambahkan air tawar dalam akuraium, sehingga salinatas dapat dipertahankan hingga salinitas air akuarium tetap normal, karenanya diperlukan salinometer. Selain kualitas air, ketersediaan pakan artemia dan udang kecil menentukan keberhasilan pertumbuhan karang. Pakan itu diberi setiap hari. Sisa pakan dan kotoran diatasi dengan filter mekanis memakai spon. Kotoran tersedot secara otomatis. Namun, filter secara rutin harus dibersihkan. Serangkaian perlakukan itu meningkatkan keberhasilan transplantasi dalam akuarium mencapai $70 \%$. Sisanya, 30 $\%$, mati. Penyebabnya kualitas air dan perubahan suhu yang tajam. Suhu akuarium pun ikut turun menjadi $24{ }^{\circ} \mathrm{C}$. Hasil transplantasi, selain dikembalikan ke alam sebagai wujud pelestarian terumbu karang juga dapat di ekspor ke mancanegara. Transplantasi untuk tujuan perdagangan karang hias, dilakukan dengan memindahkan potongan jenis-jenis karang hias yang diperdagangkan ke substrat buatan yang diletakkan di sekitar 
habitat terumbu karang alami, yang nantinya menjadi induk karang hias yang akan diperdagangkan dengan mengikuti prosedur sebagai berikut:

1 Transplantasi karang untuk tujuan perdagangan karang hias hanya boleh dilakukan olehÿpengusaha karang hias yang sudah mempunyai izin sebagai eksportir karang hias.

2 Jenis-jenis karang hias yang dibiakkan adalah jenis-jenis karang hias yang diperdagangkan untuk pembuatan aquarium, dan tidak diperdagangkan sebagai karang mati.

3 Jumlah bibit karang hias yang akan ditanam sebagai induk karang hias merupakan bagian dari kuota karang hias yang telah memperoleh persyaratan transplantasi

4 Sebelum pembiakan dilakukan, pencatatan tentang waktu kapan penanaman bibit karang hias itu dimulai, lokasi pembiakan, jumlah danjenis karang hias yang ditanam.

\subsection{Pertumbuhan Masif Alamiah Spons dalam Metode Transplantasi}

Pertumbuhan spons transplantasi dapat dikontrol dengan baik dengan melihat ukuran panjang, lebar, volume dan pengamatan adanya oscula. Sebagai contoh dapat kita lihat pada transplantasi fragmen Petrosia (Petrosia) nigricans. Nilai pertumbuhan yang digunakan adalah ukuran volume fragmen. Ukuran fragmen spons Petrosia (Petrosia) nigricans pada awal dan akhir percobaan meskipun tidak seragam untuk semua spons yang ditransplantasikan, namun tetap dapat dilakukan pengukuran dan penentuan nilai pertumbuhannya. Ketidak seragaman pertumbuhan spons transplantasi dikarenakan sulitnya mendapatkan ukuran fragmen yang sama untuk semua satuan percobaan. Hal ini disebabkan tekstur spons, misalnya Petrosia (Petrosia) nigricans yang keras sehingga menyulitkan pemotongan. Hasil pengamatan selama 30 hari mendapatkan informasi bahwa spons mengalami pertumbuhan berkisar antara 1, $39-4$, $98 \mathrm{~cm}^{3}$. Pertambahan volume sebanyak 1, $39 \mathrm{~cm}^{3}$ merupakan pertumbuhan terendah yang terdapat pada spons yang ditransplantasikan.

Kondisi fisik lokasi budidaya spons dengan metode transplantasi dalam ukuran stasiun uji coba (ST), memiliki perbedaan, biasanya perbedaan dalam hal, ST1 merupakan daerah terlindung sedangkan ST2 terbuka terhadap arus dan gelombang. Pergerakan arus pada ST2 
merupakan faktor pendukung untuk pertumbuhan spons. Arus dapat membantu spons tumbuh lebih baik karena arus dapat membersihkan spons dari sampah dan sedimen. Kondisi perairan di ST2 lebih jernih daripada ST1. Perairan jernih menguntungkan bagi spons yaitu menghemat energi karena mengurangi sekresi lendir untuk membersihkan permukaan tubuh dari sedimen. Energi tersebut dapat digunakan untuk tumbuh dan bereproduksi. Kondisi perairan dengan hempasan gelombang yang kuat dapat merugikan spons karena dapat menyebabkan hancurnya jaringan spons. Namun pada spons jenis Petrosia sp yang ditransplantasikan tidak terlalu berpengaruh karena spons ini memiliki struktur yang kuat. Posisi rak memberikan perbedaan yang nyata terhadap pertumbuhan spons. Spons pada rak horizontal dapat tumbuh lebih baik daripada yang ditansplantasikan pada rak vertikal. Posisi vertikal biasanya memiliki pertumbuhan yang lebih baik. Pada analisis statistika, interaksi antara stasiun dan posisi memberikan hasil yang berbeda nyata terhadap pertumbuhan. Pengaruh tersebut terlihat pada metode. Namun hempasan gelombang yang kuat dapat merugikan spons karena dapat menyebabkan hancurnya jaringan spons, meskipun pengaruh gelombang gelombang tidak terlalu terlihat karena kerangka spons Petrosia (Petrosia) nigricans keras dan sulit terlepas dari tali. Hasil analisis dengan menggunakan korelasi Pearson menunjukkkan bahwa hubungan yang erat antara pertumbuhan spons Petrosia (Petrosia) nigricans dengan salinitas, kecerahan dan kerapatan optik pada stasiun 2. Korelasi yang berbeda ditemukan di stasiun 1, pertumbuhan tidak berhubungan erat dengan parameter lingkungan transplantasi.

\section{6. 1. Tingkat Pertumbuhan Spons Transplantasi}

Secara umum, spons mengalami pertumbuhan misalnya Petrosia, berkisar antara $0,33-1,94 \mathrm{~cm}$ selama 30 hari. Posisi rak vertikal memperlihatkan pertumbuhan lebih tinggi daripada horizontal. Perbedaan pertumbuhan disebabkan oleh dua faktor yaitu aliran air dan sedimentasi. Posisi vertikal mendapatkan aliran air lebih baik daripada posisi horizontal. Aliran air yang kuat dapat membawa makanan yang diperlukan oleh spons untuk tumbuh. Aliran arus yang tinggi dapat meningkatkan pertumbuhan bagi suspension feeder seperti spons. Posisi vertikal memberikan keuntungan bagi spons dalam hal memperkecil kemungkinan 
spons tertutup sedimen. Sedimen dapat merugikan spons dan mempengaruhi pertumbuhan spons. Sedimentasi yang tinggi menyokong perkembangan bakteri dibagian yang terluka. Hasil analisis dengan menggunakan korelasi Pearson menunjukkkan bahwa hubungan yang erat antara pertumbuhan spons Aaptos aaptos dengan salinitas.

\section{6. 2. Efektifitas Transplantasi Spons}

Kelangsungan hidup spons di lokasi transplantasi biasanya berbeda antara satu lokasi dengan lokasi lainnya karena berbagai faktor. Kondisi lokasi yang diduga merupakan penyebab adanya perbedaan tingkat kelangsungan hidup spons, misalnya pertumbuhan spons pada daerah terbuka dan berarus berbeda signifikan dengan daerah tertutup dan kurang berarus atau karena kekeruhan sehingga lebih kecil pertumbuhannya, atau daerah yang mengalami sedimentasi tinggi. Sedimentasi tinggi dapat menyebabkan kematian spons. Cara transplantasi juga akan memberi pengaruh nyata pada tingkat kelangsungan pertumbuhan spons transplantasi. Secara umum spons yang ditransplantasikan pada rak horizontal memiliki tingkat kelangsungan hidup lebih tinggi daripada rak vertical. Pembersihan pada arak memberikan hasil yang berbeda dengan rak transplantasi yang tidak dibersihkan. Umumnya rak transplantasi yang dibersihkan mengalami pertumbuhan lebih baik dibandingkan dengan yang tidak dibersihkan. Faktor lainnya adalah $\mathrm{pH}$, DO dan salinitas memiliki korelasi yang erat dengan kelangsungan hidup suatu spons yang yang hidup pada lingkungan habitat alami maupun spons yang ditransplantasipada lingkungan tertentu. SCebagai contoh dapat kita lihat pada pertumbuhan fragmen Petrosia (Petrosia) nigricans Nilai pertumbuhan yang digunakan adalah ukuran volume fragmen. Ukuran fragmen spons Petrosia (Petrosia) nigricans pada awal penelitian tidak seragam, dikarenakan sulitnya mendapatkan ukuran fragmen yang sama untuk semua satuan percobaan. 



\section{DAFTAR PUSTAKA}

Adiyodi RG, 1992, Reproductive Biology of Invertebrates, Sexual Differentiation and Behaviour, John Wiley \& Sons, New York.

Affandi, R. \& Tang, U.M. 2002. Fisiologi Hewan Air. Riau :Unri Press. hlm 94-98.

Ahmad, T., E., Suryati, and Muliani, 1995, Spons bioactive screening for bactericide in shrimp culture, Indonesia Fisheries Research Journal, 1 (1), 1-10.

Allen, G.R. 1997. Tropical Marine Life of Indonesia. CV. Java Books. Jakarta.

Allen, G.R. and R. Steen. 1994. Indo-Pasific Coral Reef. Field Guide. Tropical Reef Research. Singapore. 378 p.

Amir, I. 1991. Fauna Spons (Porifera) dari Terumbu Karang Genteng Besar, Kepulauan Seribu. Oseana 24: $131-140$.

Amir, I. dan A. Budiyanto. 1996. Mengenal Spons Laut (Demospongiae) Secara Umum. Oseana. Vol 21 (2):15-31.

Amir, I., 1991, Fauna Spons (Porifera) dari Terumbu Karang Genteng Besar Pulau-Pulau Seribu, Oseanologi di Indonesia, (24), 41 - 54.

Andari I, Wahyono D. Penggunaan obat generik di apotek wilayah Kodya Yogyakarta pada masa krisis moneter (Maret 1997-Maret 1998). Majalah Farmasi Indonesia. 2002;13(1): p.12-20

Andayani, R., L. Yovita, \& Maimunah, 2008, Penentuan aktivitas antioksidan, kadar fenolat total dan likopen pada buah Tomat (Solanum lycopersicum L.) J. Sains dan Teknologi Farmasi,13(1) 31-37.

Angeline E. C. Ngantung1, Deiske A. Sumilat1, Robert A. Bara, 2016. Uji Aktivitas Antibakteri dari Spons Dictyonella funicularis dan Phyllospongia lamellosa yang diPeroleh dari Perairan Bunaken, Jurnal Pesisir dan Laut Tropis, Vol 2 (1):10-16

Anonim C. Metabolit sekunder Callyspongia sp. [Online]. 2011 September 9 [cited 2013April 27]; Available from: http://www.artikelkimia.info/metabolitsekunder-callyspongia-sp-1 3021409092011

Aoki, S., Naka, Y., Itoh, T., Furukawa, T., Rachmat, R., Akiyama, S., and Kobayashi, M., 2002, Lembehsterols A and B, Novel Sulfated Sterols Inhibiting Thymidine Phosphorylase, from the Marine Spons Petrosia strongylata, chem. Pharm. Bull., 50 (6) 827-830.

Asaf, R. 2009. Keterkaitan Kondisi Tutupan Karang Hidup dengan Kandungan Metabolit Sekunder Sponge [Tesis]. Unhas, Makassar.

Ashour, M. A. A., 2006, Structure Elucidation of Bioactive Marine Natural Products Using Modern Methods of Spectroscopy, diseretation.

Asro, Muhammad; Yusnaini; Halili, 2013. Pertumbuhan Spons (Stylotella aurantium) yang Ditransplantasi pada Berbagai Kedalaman, Jurnal Mina Laut Indonesia, vol. 1(1):122-144

Astuti, P., 2003, Spons Invertebrata Laut Berpotensi Sebagai Sumber Bahan Baku Obat Alam, Oseana, 8 (26).

Astuti, P., G. Alam., S.U.P. Pratiwi., T. Hertiani dan S. Wahyuono. 2003. Skrining Senyawa Antifeksi dari Spons yang Dikoleksi dari Bunaken, Manado. Biota. 08 (2) : 47-52.

Azadeh M, Kermanshahi R, Naghavi N, Ghalayani P, Salamat F. The profil of pathogenic isolated from dental plaque- induced gingivitis. International Journal of Molecular and Clinical Microbiology 1. 2011;p.36-9

Bergquist, P.R. 1978. Sponges. Hutchinson, London. 268 p. 
Bewley, C.A and Faulkner, D.J., 1998, Lithistid Sponges: Star Performers or Hosts to the Stars, Angewandte Chemie international, 37, 2162-2178

Bhakuni, D.S., D.S. Rawat, 2005. Bioactive Marine Natural Products. Anamaya, India.

Bhargavi S, Gopala V, Mukkanti K, Dinesh B, Krishna P. Increasing emergence of antibacterial resistance mainly in uropathogens: southest part of India. International journal of microbiology research. 2010;2(1): p.01- 06

BKSDA, 2009. Taman Wisata Alam Pulau Kapoposang (online), (http://.www. ditjenphka. go,id.kawasa.html. diakses 12 Februari 2009)

Braekman, J. C., and Daloze, D., 1986, Chemical defence in sponss, Pure \& Appl. Chem., 58 (3), 357-364.

Brown, B.E., and T.B. Scoffin. 1986. Human induced damage to coral reef. Diponegoro University Semarang and National Institute Oceanology. 42 p.

Cetkovic and Lada. 2003. Protein from the Marine Sponge Suberites domuncula Food Technology and Biotechnology 2003 (41) 4 pp 361

Cho, H. J., S. Ja Bae, N. D. Kim, J. H. Jung and Y.H. Cho., 2004, Induction of Apoptosis by Dideoxypetrosynol A, A Polyasetylene from Spons Petrosia sp., in Human Skin Melanoma Cells, International Journal of Molecular Medicine, 1091-1096.

Cimino, G., de Giulio, A., de Rosa, S., di Marzo, V., 1989, Tetrahedron Lett, 30, 3563 3566.

Clarke, S., Modern Medical Microbiology The Fundamental, Arnold Members Of Hodder Headline, London UK. Hal 83-85.

Cole, G.A.. 1988. Textbook of Limnology. Third edition. Waveland Press, Inc., Illinois, USA.

Cooper, E.L., 2004, Evidence-based Complementary and Alternative Medicine, eCAM, $1,215-217$

Cowan, M. Plant products as antimicrobial agents. Clin Microbio Reviews. 1999;12(4): p.564-82

Dahuri, R, 2004, Industri Bioteknologi Perairan dan Kemakmuran Bangsa, Kompas, Gedia Press, Jakarta.

Daintith, J., 1994, Kamus Lengkap Kimia, Erlangga, Jakarta, 144. De Voogd, N. J., Haftka, J. J. H., Hoeksema, B. W., 2005, Evaluation Of The Ecological of Amphitoxin In The Reef-Dweeling Sponge Callyspongea (Euplacella) Biru (Haploscerida) At South Sulawesi, Indonesia (Online), (http://dpc.uba.uva. nl/ctz/vol74/nr01/art04), diakses 3 Februari 2016 jam 16.45 WITA).

Darby, E., 1995. A. Tutorial Superficial Fungal Infection of The Skin, (Online). http://www. lookshark.com/showcase/fungus/versicolor.htm. diakses 7 Februari 2009).

De Voogd N. Indonesian sponges : Biodiversity and marine culture potential. [Tesis]. Univ of Amsterdam : 2005

Dewanti S. Antibacteri activity of bay leaf infuse (Folia syzygium polyanthum WIGHT) to Eschericia coliin-vitro. Jurnal Medika Planta. 2011;1(4)

Dewi, A.S., Kustiariyah Tarman., Agustinus R. Uria. 2008. Marine Natural Products and Impacts on the Sustainable Development in Indonesia. Proceeding of Indonesian Students' Scientific Meeting, Delft, Netherland

Diakses 20 Agustus 2009.

Djajadisastra, A.N. 2007. Penapisan Komponen Antibakteri dan Uji Toksisitas dari Spons Perairan Taka Bonerate Sulawesi Selatan [Skripsi]. Bogor. Program Studi Teknologi Hasil Perikanan Fakultas Perikanan dan Ilmu Kelautan Universitas Institut Pertanian Bogor. 
Djide, N., Sartini, Kadir, S., 2004. Analisis Mikrobiologi Farmasi. Laboratorium Mikrobiologi Farmasi. F.MIPA UNHAS, Makassar, 283-284

Duchassaing 1864. Sponges Callyspongia fallax. http://www.Coralpedia .bioWarwick.ac.uk/ en/sponges.htm.

Duckworth AR, Battershill CN, Schiel DR, Berquist PR. 1997. Influence of Explant Producers and Environmental Factors on Cultur Succes of Three Sponges. Quensland Museum.

Duckworth, A.R., Battershill, C.N. \& Bergquist, P.R. 1997. Influence of Explant Procedures and Environmental Factors on Culture Success of Three Sponges. Aquaculture 165: 251-267.

Ebada S, Lin W, Proksch P. Bioactive sesterterpenes and triterpenes from marine sponges: occurrence and pharmacological significance. [Online]. [updated 2010 Februari 23; cited 2013 April 17]. Available from: http://www.ncbi.nlm. nih.gov/pmc/articl es/PMC2852841/Uu

Effendi, H.. 2003. Telaah Kualitas Air. Kanisius. Yogyakarta. English, S.C.; Wilkinson and Baker,V., 1997. Survei Manual for Tropical Marine Resources. Asean. ASEAN Australia Marine Science Project: Living Coastal Resources.

El Sayed, K. L., Kelly, M., Kara, U. K., Ang, K. H., Katsuyama, I., Dunbar, D.C., Khan, A. A., and Hamann, M.T., 2001, New Manzamine Alkaloids with Potent Activity against Infectious Disease, J. Am. Chem. Soc., 123, 18041808.

Entjang, I., 2003. Mikrobiologi \& Parasitologi, PT. Citra Aditya Bakti, Bandung. 100101.

Erhardt, H., dan Moosleitner, H., 1995, Meerwater Atlas Band 2, Mergus, Jerman.

Fachrudin Mangunwijaya, 2004, Bioteknologi Berbasis Kekayaan Hayati,Sinar Harapan, Jakarta, http://www.geocity.com

Fallu, 1991., Abalone Farming, Fishing News Book, Oshey Mead, Oxford Oxoel, England. Fukami, A., Ikeda, Y., Kondo, S., Naganawa, H., Takeuchi, T., Furuya, S., Hirabayashi, Y., Shimoike, K., Hosaka, S., 1997, Akartepin, A Novel Bioactive Tripene From Marine Sponge Callyspongia Sp, Zoology, 7 (38), 1201-1202.

Faulkner, D.J. 2000. Marine Natural Products. Nat. Prod.Rep. 17:7-55.

Ganiswara, S. 1995. Farmakologi dan Terapi. Edisi IV. Bagian Farmakologi Fakultas Kedokteran. Universitas Indonesia. Jakarta. 572-573.

Garson, M.J., 1994, The Biosynthesis of Secondary Metabolits: Why is Important. In: Sponss in Timeand Space, pp: 428-429, edited by R.W.M. van Soest, Th. M.G. Van Kempen and J.CBraekman (eds.)., Proceeding 4th International Porifera Conggress, Amsterdam/Netherland.

Gordon, M. H., 1990, The Mechanism Of Antioxidants Action In Vitro, Elsevier Applied Science, London.

Goud,T. V., Reddy, N. S., Swamy, N. R., Ram, T. S., and Venkateswarlu, Y., 2003, AntiHIV Active Petrosins from the Marine Spons Petrosia similis, biol. pharm. bull., 26 (10) 1498-1501.

Goutara, Ciptadi W, Djatmiko B, Wahab T. A., 1980, Mempelajari Pembuatan Minyak Kelapa Dengan Cara Ekstraksi Basah Serta Pemakaian Antioksidan Pada Kelapa Santan, Departemen Teknologi Hasil Perairan, Institut Pertanian Bogor, Bogor.

Gray, C. A., De Lira, S. P., Silva, M., Pimenta, E. F., Thienmann, O. H., Oliva, G., Hajdu, E., Andersen, J. A., Berlinck, R. G. S., 2006, Sulfated Meroterpenoids from Brazilian Sponge Callyspongia Sp, Org.Chem, 71 (23), 8685-8690.

Guo, Y., Gavagnin, M., Trivellone, E., Cimino, G, 1994, Tetrahedron, 50, 13261

Guyot, M. 2000. "Intricate aspects of sponge chemistry". ZOOSYSTEMA, 22: 419-431 
Hadi, T. A. 2010. Biologi dan Ekologi Spons. Oseana. Jurnal. Volume XXXV No. 1, 33 -48 .

Haedar N. Purdian H. Bioaktivitas bakteri Chromohalobacter sp. dari spons Callyspongia sp. terhadap bakteri patogen. FMIPA Universitas Hassanudin. 2010

Haedar, Baru Sadarun, Ratna Diyah Palupi, 2016. Potensi Keanekaragaman Jenis dan Sebaran Spons di Perairan Pulau Saponda Laut, Kabupaten Konawe, Jurnal Sapa Laut Vol. 1 (1):1-9;

Halliwell, B., Gutteridge, JMC., 1989, Free Radical In Biology and Medicine, New York, Oxford University Press.

Hamilton, R. J., 1983, The chemistry of ranciditry in food, Applied Science Publisher, New York, 1-20

Hanani, E, Mun'im A, Sekarini, R, dan Wiryowidagdo, S. Uji aktivitas antioksidant beberapa spons laut dari kepulauan Seribu, Jurnal Bahan Alam Indonesia,vol 5, no.1 Jan 2005 (in Press).

Hanani, E., Mun'im, A., dan Sekarini, R., 2005, Identifikasi Senyawa Antioksidan Dalam Spons Callyspongia sp. Dari Kepulauan Seribu, Majalah Ilmu Kefarmasian, 3(2), 127-133.

Handayani D, Deapati M, Marlina, Meilan. Skrining aktivitas antibakteri beberapa biota laut dari Perairan Pantai Painan, Sumatera Barat. [Makalah]. Unand : 2009

Handayani, D., Sayuti, N., dan Dachriyanus, 2008, Isolasi dan Karakterisasi Senyawa Antibakteri Epidioksi Sterol dari Spons Laut Petrosia Nigrans, Asal Sumatra Barat, Prosiding Seminar Nasional Sains Dan Teknologi-II 2008 Universitas Lampung, 17-18 November 2008.

Harbane, J. B., 1987, Metode Fitokimia, Insitut Teknologi Bandung, Bandung. Hooper, J. N. A., 2003, Sponguide: Guide to Sponge Collection and Identification, Queensland Museum, South Brisbane, Australia.

Hardbone. J.B., 1987. Metode Fitokimia, Penuntun Cara Modern Mengekstraksi Tumbuhan. Edisi II. Penerbit ITB Bandung.

Hardiningtyas S. Aktivitas antibakteri ekstrak karang lunak Sarcophyton sp. yang difragmentasi dan tidak difragmentasi di perairan Pulau Pramuka Kepulauan Seribu. [Skripsi]. IPB:2009

Haris, A. 2004. Pertumbuhan, Sintasan, Perkembangan Gamet, dan Bioaktivitas Ekstrak dan Fraksi Spons Aaptos aaptos yang Ditransplantasikan pada Perairan yang Berbeda [disertasi]. Bogor: Sekolah Pascasarjana, Institut Pertanian Bogor.

Harper, M.K., T.S. Bugni, B.R. Copp, R.D. James, B.S. Lindsay, A.D.Richadson, P.C. Schnabel, D. Tasdemir, R.M. Van Wangoner, S.M Verbitski and C.M. Ireland, 2001, Introduction to the chemical ecology of marine natural product, Marine Chemical Ecology (James B. McClintock \& Bill J. Baker Eds.) CRC Press USA. Pp 3-29.

Harrison, F. W., and De Vos, L., 1991, Porifera, Di dalam: Harrison FW, Westfall JA (ed.). Microscopic Anatomy of Invertebrates.Volume 2. Placozoa, Porifera, Cnidaria, and Ctenophora.Wiley-Liss. A John Wiley \& Sons, Inc., Publication. New York, Chicester, Brisbane, Toronto, Singapore, 28 -89.

Hartono B. Kajian kesesuaian sumberdaya terumbu karang untuk pengembangan ekowisata bahari di Kelurahan Pulau Abang Kota Batam. [Online]. [cited 2013 April 17]; Available from: http://repository.ipb.ac.id/bitstream/han dle/123456 $789 / 41472$

Haslam, S. M. 1995. River Pollution and Ecological Perspective. John Willey and Sons, Chichester, UK. 
Haveles E. Applied pharmacology for the dental hygienist. 6thedition. Misouri: Mosby Elsevier. 2011.

Higa, T., Tanaka,J., Kitamura, A., Koyama, T., Takahashi, M., and Uchida, T., 1994, Bioactive compounds from marine sponss, Pure \& Appl. Chern., 66 (10/11), 2227-2230.

Hooper, J.N,A., 1997. Guide to sponge collection and identification. Version Merch. Queensland Museum South Brisbane, Journal Queensland, Australia, 26-29

Hooper, J.N.A and van Soest, R.W.M., 2002, Systema Porifera: A Guide to Classification of Sponges, pp: 674-675 volume 1, Kluwer Academic, Plenum Publisher, New York.

Hooper, J.N.A. 2000. Sponguide: guide to sponge collection and identification. Queensland: Queensland Museum.

Hosettman, K., 1991, Methods in Plant Biochemistry, Academic Press, New York, 6.

Hutagalung, H. P. dan A Rozak. 1997. Metode Analisis Air Laut, Sedimen dan Biota Laut. Institut Pertanian Bogor. Bogor.

Ireland, C. M., Molinski, T. F., Roll, D. M., Zabriskie, T. M., McKee, T. C., Swersey, J. C., and Foster, M. P., 1989, Natural Product Peptides from Marine Organisms, Di dalam Scheuer PJ (ed.), Bioorganic Marine Chemistry, Springer - Verlag, 3, 127.

Isaacs, S., Kashman, Y., Loya, S., Hizi, A., Loya, Y., 1993, Tetrahedron, 49, 1043510438.

Ismet M. Penapisan senyawa bioaktif spons Aaptos aaptos dan Petrosia sp. dari lokasi yang berbeda. [Tesis]. Pasca Sarjana IPB: 2007

Ismet, et al.., 2011, Analisis Morfologi dan Biomassa Spons, Jurnal Ilmu dan Teknologi Kelautan Tropis, Vol. 3, No. 2 (157-165).

Ismet, Meutia, S., 2007, Penapisan Senyawa Bioaktif Spons Aaptos Aaptos Dan Petrosia Sp. Dari Lokasi Yang Berbeda, Institut Pertanian Bogor, Bogor.

Janiel. Wulff. 2000. Sponge Predators May Determine Differences In Sponge Fauna Between Two Sets Of Mangrove Cays, Belize Barrier Reef. Washington, D.C., U.S.A.

Jeffries, M. and D Mills. 1996. Freshwater Ecology, Principles, and Aplications. John Wiley and Sons, Chichester, UK.

Jompa, J., Moka, W., Yanuarita, D., 2010. Kondisi Ekosistem Perairan Kepulauan Spermonde: Keterkaitannya dengan Pemanfaatan Sumberdaya Laut di Kepulauan Spermonde, Divisi Pengembangan Kelautan, Universitas Hasanuddin.

Karyawati, A.T. 2010. Aktivitas Antivirus dari Ekstrak Spons Clathria basilana dan Oceanapia amboinensi Terhadap Simian Retrovirus Serotipe-2 Secara In-Vitro [Tesis]. Bogor. Pascasarjana Institut Pertanian Bogor.

Kelly, M., 2001, A Course Guide to the Sponge Taxonomy Workshop, Departement Of Pharmacognocy Biologycal Field Station University Of Mississipi and NIWA, New Zealand.

Kencanawati, N. 1993. Ekstraksi Senyawa Aktif dari Famili Euphorbiaceae Serta Pengaruhnya terhadap Pertumbuhan Bakteri Eschercia coli dan Staphylococcus aureus. FMIPA. Institute Pertanian Bogor.

Kennish, M. J., 1989, Practical Handbook Of Marine Science, CRC Press, Florida. Ketaren, S., 2008, Lemak dan Minyak Pangan, UI Press, Jakarta.

Kimura, J., Ishizuka E., Nakao Y. Yoshida W.Y, Scheuer, P.J., and Borges, K. 1998. Isolation of 1- methylherbipoline Salt of Halisulfate-1 and of Suvanine as Serine 
Protease Inhibitors from Marine Spons, Coscinoderma Mathewsi, J. Nat Prod 61 (28), 248- 250.

Kobayashi, M and R. Rachmaniar. 1999. Overview of Marine Natural Products Chemistry. Prosidings Seminar Bioteknologi Kelautan. LIPI, Jakarta. 23 - 32.

Koesbiono, 1981.Biologi Laut. Fakultas perikanan. Institut Pertanian Bogor. Bogor

Krisyuninda M. Uji toksisitas fraksi spons Callyspongia sp. dengan metode brine shrimp test dari perairan pasir putih situbondo. Institut Teknologi Sepuluh November : 2012

Kunitz, M., and J.H. Northrop, 1936, Isolation from Beef Pancreas of Crystalline trypsinogen trypsin, a trypsin, and an Inhibitor- Trypsin Compound, J. Gen. Physio, 19(31), 991 - 1007.

Lawson, M.P., P.R. Bergquist and R.C. Cambie. 1984. Fattayacid Composition and The Classification of The Porifera. Biochem. System and Ecol. 12 (4): 375-394.

Lee KY, Lee HJ, Lee HK., 2001, Microbial Symbiosis in Marine Sponss, TheJournal of Microbiology, 29 (4), 254-264.

Lehninger, AL., 1993. Dasar-dasar Biokimia Jilid 1, Erlangga, Jakarta. Molyneux, P., 2004, The Use Of Stable Free Radical Diphenylpicrylhydrazyl (DPPH) Or Estimating Antioksidan Activity, Songklanakarin J Sci Technol 26(2) 211-219.

Li, H., Matsunaga, S., Fusetani, N., 1994, J. Nat. Prod., 57, 1464-1467.

Mahon, C. R., Manuselis, G. 1995, Textbook of Diagnostic Microbiology, W. B. Saunders Company, Tokyo.

Lydia, M., Alfian, N., Tjodi, H., Nicole, de, V., 2014. Essential Metal Zn in Sponge Callyspongia aerizusa from Spermonde Archipelago, Advances in Biological Chemistry Journal, vol. 4: 86-90, http://dx.doi.org/ 10.4236/abc,2014.41012

Marzuki, I., 2016. Potensi Biodegradasi Hidrokarbon Limbah Sludge Minyak Bumi oleh Mikrosimbion dan Biomassa Spons Laut, Disertasi, Sekolah Pasca Sarjana, Universitas Hasanuddin, Makassar, URL:https://www.researchgate. net/publication/324908844

Marzuki, I., Noor, A., Djide, N.M., La Nafie, N., 2014a. Isolation and Identification on Degradator Bacterial of Petroleum waste which Symbionts with Sponge Callyspongis sp from Melawai Beach. Proceeding: International Confrence on the sciences (ICOS), 19-20 Nopember 2014, Makassar, ISBN : 9786027219809, pp. 493-503; Doi: 10.17605/OSF.IO/PZVKC

Marzuki, I., Noor, A., Djide, N.M., La Nafie, N., 2014b. Isolasi dan Identifikasi Bakteri Shimbion Spons Penghasil Enzim Amilase Asal Pantai Melawai Balikpapan, Jurnal dr.Aloei Saboe, vol.1 (1):11-18; Doi: 10.17605/OSF.IO/R4JYA

Marzuki, I., Noor, A., Djide, N.M., La Nafie, N., 2015a, Molecular characterization of gene 16S rRNA micro symbionts in sponge at Melawai Beach, East Kalimantan, Journal Marina Chimica Acta, 16 (1):38-46; Doi:10.17605/OSF.IO/XKP9B

Marzuki, I., Noor, A., Djide, N.M., La Nafie, N., 2015b, The potensi biodegradation hydrocarbons of petroleum sludge Waste by cell biomassa sponge Callyspongia sp, Journal Marina Chimica Acta, 16 (2):11-20; Doi: 10.17605/OSF.IO/RCNDW

Marzuki, I., Noor, A., Djide, N.M., La Nafie, N., 2015c, Sponge role in alleviating oil pollution through sludge reduction, a preliminary approach, Int. Journal of Applied Chemistry, 11 (4):427-441; Doi: 10.17605/OSF.IO/S9HTG

Marzuki, I., Noor, A., Djide, N.M., La Nafie, N., 2016a. Microsymbiont and Morphological Phenotype Analysis Marine Sponge Biomass From Melawai Beach, Balikpapan, East Kalimantan, Journal Marina Chimica Acta, 17 (1):8-15; Doi: 10.17605/OSF.IO/P73EN 
Marzuki, I., 2016b, Mikrosimbion Spons Callyspongia Sp sebagai Biomaterial Pendegradasi Hidrokarbon, Prosiding Seminar Nasional Kimia, LombokMataram, Vol 1: 480-450; Doi 10.17605/OSF.IO/KEHVF

Marzuki, I., Erniati, 2017. Skrining Spons Potensial sebagai Biodegradator Hidrokarbon Berdasarkan Data Morfologi, Prosiding Seminar Nasional Hasil Penelitian (SNP2M), pp. 43-48, ISBN 978-602-60766-3-2; Doi: 10.17605/OSF.IO/M5DWS

Masak, P.R.P. 2003. Studi Budidaya Sponge (Auletta sp) Secara Transplantasi pada Substrat Berbeda. Maritek 3:1-9.

Mayer, A.M.S. 1999. Marine Pharmacology in 1998: Antitumor and Cytotoxic Compounds. The Pharmacologist. 41 (4): 159-164.

Mc.Neely, R.N., Nelmanis, V.P, and Dwyer, L. 1979. Water Quality Source Book A Guide to Water Quality Parameter. Inland Water Directorate. Water Quality Branch. Ottawa.

Meyer, B.N., Ferrigni, N.R., Putman, J.E., Jacobsen, D.E., Nichols, D.E., McLaughlin, J.L., 1982, Brine Shrimp L A Convenient General Bioassay for Active Plant Constituent, Planta Medica, 45, 31-34.

Morrow, Christine and Cardenas, Paco. 2015. Proposal for a revised classification of the Demospongiae (Porifera). Frontier in Zoology. 12:7 (update)

Muliani, Suryati E., Tompo A., Parenrengi A., Rosmiati, 1998, Isolasi BioaktifBunga Karang Sebagai Fungisida pada Benih Udang Windu Penaeus monodon, Jurnal Penelitian Perikanan Indonesia, 4 (2).

Muniarsih T., dan Rachmaniar R., 1999, Isolasi Substansi Bioaktif Antimikrobadari Spons Asal Pulau Pari Kepulauan Seribu. Makalah disajikan dalam Seminar Bioteknologi Kelautan Indonesia I, Lembaga Ilmu Pengetahuan Indonesia Jakarta, Jakarta 14 Oktober.

Munifah, I., Wikanta, T., dan Nursid, M., 2006, Biota Laut Penghasil Senyawa Bioaktif Yang Potensial, Pusat Riset Pengolahan Produk dan Sosial-Ekonomi Kelautan dan Perikanan.

Munro M. H. G., Luibrand R. T., and Blunt J. W., 1989, The Search for Antivaral and Anticancer Compounds from Marine Organisms. Di dalam Scheuer PJ (ed.), Bioorganic Marine Chemistry, Springer -Verlag, 1, 94-176.

Munro, M.H.G., Luibrand, R. T., and Blunt, J. W. 1987. The Search for Antiviral and Anticancer Compounds from Marine Organism. In: Scheuer, P. J., Bioorganic Marine Chemistry. Vol. 1. Springer-Verlag, Berlin. P.94-165.

Murniasih T, Rasyid A. Potensi bakteri yang berasosiasi dengan spons asal Barrang Lompo (Makassar) sebagai sumber bahan antibakteri. Pusat Oseanografi dan LIPI: 2010

Murniasih, T. 2003. Metabolit Sekunder dari Spons Sebagai Bahan Obat-Obatan. Oseana, XXVIII (3): 27-33.

Murniasih, T. 2005. Substansi Kimia Untuk Pertahanan Diri dari Hewan Laut Tak Bertulang Belakang. Oseana. XXX (2): 19-27.

Murti, Y. B., 2006, Isolation and structure elucidation of bioactive secondary metabolites from sponss collected at Ujungpandang and in the Bali Sea, Indonesia, Disertation.

Musthafa, Z., Lawrence, GS, dan Seweang A., 2000, Radikal Bebas Sebagai Predictor Aterosklerosis Pada Tikus Wistar Diabetes Mellitus. Cermin Dunia Kedokteran (127) 30-31. 
Nontji, A dan A Djamali. 1980. Teluk Jakarta. Pengkajian Fisika, kimia, Biologi dan Geologi Tahun 1975-1979. Lembaga Oseanologi Nasional-Lembaga Ilmu Pengetahuan Indonesia. Jakarta.

Nontji, A dan R. Satari. 1996. Potensi Pengembangan Bioteknologi Kelautan di Indonesia, 49-56. Dalam Herunadi, B., I. Mudita, dan Udrekh (Eds.) Prosiding Konvensi Nasional Pembangunan Benua Maritim Indonesia dalam Rangka Mengaktualisasikan Wawasan Nusantara, Makassar 18-19 Desember 1996.

Noor, A., 2007. Riset Kelautan Berorientasi Terapan: Keperluan Mendesak Bagi Kawasan Timur Indonesia. Kongres Ilmu Pengetahuan Wilayah Untuk Kawasan Timur Indonesia. Pusat Kegiatan Penelitian Universitas Hasanuddin Makassar 2324 April.

Novotny, V. and Olem, H. 1994. Water Quality, Prevention, Identification and Management of Diffuse Pollution. Van Nostrans Reinhold. New York.

Nursid, M., T.Wikanta., N.D. Fajarningsih dan E. Marraskuranto. 2006. Aktivitas Sitotoksik, Induksi Apoptosis dan Ekspresi Gen p53 Fraksi Metanol Spons Petrosia cf. Nigricans Terhadap

Nybakken, J. W. 1988. Biologi Laut Suatu Pendekatan Ekologis. PT Gramedia. Jakarta. O’Keefe, B. R., Erim,T., Beutler, J.A., Cardellina, J.H., Gulakowski, R.W.J., Krepps, B. L., Mcmahon, J. B., Sowder, R. C., Johnson, D. G., Buckheit, ～R.W.J., Halliday, S., And Boyd, M. R., 1998, Isolation and Characterization of adociavirin, a Novel HIV-Inhibitory Protein from the Spons Adocia sp FEBS Lett, 431 (44), 85 - 90.

Ozyurt, D., Demirata, B., Apak, R,. 2006, Determination Of Total Antioxidant Capacity By A New Spectrophotometric Method Based On Ce(IV) Reducing Capacity Measurement, Talanta (24) 273- 282.

Parenrengi, A., E. Suryati, Dalfiah, dan Rosmiati. 1999. Studi Toksisitas Ekstrak Sponge Auletta sp, Callispongia sp, dan Callispongia pseudoreticulata Terhadap Nener Bandeng (Chanos chanos). Jurnal Penelitian Perikanan Indonesia. Pusat Penelitian dan Pengembangan Perikanan, Badan Penelitian dan Pengembangan Pertanian Departemen Pertanian, Jakarta, Vol. V No. 4. 1999.

Pelczar M.J dan E.C.S Chan. 1988. Dasar-dasar Mikrobiologi. Jilid 2. Jakarta. UI Press. Proksch, P. 1999. Pharmacologically Active Natural Products from Marine Invertebrates and Associated Microorganisms. Prosidings Seminar Bioteknologi Kelautan. LIPI, Jakarta. 33-40.

Poedjiadi, A., 1994, Dasar-dasar Biokimia, UI-Press, Jakarta. Rachmaniar, 2003, Produk Alam Laut Sebagai Lead Compound Untuk Farmasi Dan Pertanian, Dibawakan Pada Seminar Sehari Perfektif Baru Dalam Drug, Discovery, Makassar, 26 Oktober 2003.

Prishandono D, Radiati LE, Rosyidi D. Pengaruh penambahan ekstrak picung (Pangium edule) dengan air dan etanol terhadap recovery Eschericia coli dan Staphylococcus sp. serta total mikrobia pada daging sapi giling. Malang: Universitas Brawijaya.2013

Pronzato, R., Bavestrello, G., Cerrano, C., Magnino, G., Manconi, R., Pantelis, J., Sara, A., and Sidri M., 1999, Spons Farming in the Mediterranian Sea New Perspectives, Memoir of the Queensland Museum, 44, 485 - 491.

Rachmaniar, R. 1997. Potensi Spons Asal Kepulauan Spermonde Sebagai Antimikroba. Seminar Perikanan Indonesia II. Ujung Pandang. 2-3.

Rachmaniar, R. 2003. Antikanker Swinholide dari Spons Theonella swinhoei. Jurnal Bahan Alam Indonesia. 2 (04): 1412-2855. 
Rachmaniar, R. 2007. Spons Indonesia Kawasan Timur Keragaman, Distribusi, Kelimpahan, dan Kandungan Metabolit Sekundernya. Oseanologi dan Limnologi di Indonesia. 33 (1): 123-138

Rachmat R. Spons Indonesia kawasan timur. Oseanologi dan Limnologi di Indonesia. 2007; 33: p.123-38

Rahayu I. Aloe barbandesis Miller dan Aloe chinensis Baker sebagai antibiotik dalam pengobatan etnoveteriner unggas secara in-vitro. Jurnal protein. 2006; 13(1) Ahmad, T., E. Suryati, dan Muliani. 1995. Screening Sponges for Bactericide To Be Use in Shrimp Culture. Indonesian Fisheries Research Journal.

Rahman, R. Abd dan Ahmad Ridhay, 2004, Penapisan Senyawa Antimikroba Dari Beberapa Jenis Bunga Karang (Porifera), Tesis tidak diterbitkan. Makassar, Jurusan Farmasi Universitas Hasanuddin.

Rahmat, R., 2007, Toksisitas dan aktivitas Antimikroba Ekstrak Etanol Bunga karang dari perairan Pulau Tabuhan Banyuwangi dan Pulau Menjangan Bali Barat, Jurnal Perikanan (J. Fish. Sci.) IX, 167-173

Rakesh, SU., Patil, PR., Salunkhe, VR., 2010, Free Radical Scavenging Activity Of Hydroalcoholic Extracts Of Dried Flowers Of Nymphaea Stellata Willd. International Journal of Pharma and Bio Sciences 1(2),1-9.

Ranney, MW., 1979, Antioxidant Recent Development, Noyes Data Co. Park Ridge, USA, 87-121.

Reinheimer, G., 1991, Aquatic Microbiology, 4 th Ed, John Wiley and Sons, Chichester and New York.

Riseley, R. A., 1971, Tropical Marine Aquaria, The Natural System, George Allen \& Unwin Ltd, Ruskin Hause Museum Street, London, 164 - 165.

Rita, A., Tania, SU., Heri, H., Albana, AM., dan Rini, R., 2009, Produksi Antioksidan Dari Daun Simpur (Dillenia indica) Menggunakan Metode Ekstraksi Tekanan Tinggi Dengan Sirkulasi Pelarut, Perhimpunan Teknik Kimia Indonesia, Bandung, $1-8$.

Rogers, C. S., Garrison G., Grober, R., Hillis Z and ranke, M. A. 1994. Coral Reef Monitoring Manual for the Carribean and Western Atlantic. Virgin Island National Park USVI.

Romihmohtarto, K., dan Juwana, S., 1999, Biologi Laut,Ilmu Pengetahuan tentang Biota Laut, Pusat Penelitian dan Pengembangan Oseanologi-LIPI Jakarta, 115 128.

Romimohtarto, K., dan Juwana, S., 2007, Biologi Laut, Ilmu Pengetahuan Tentang Biota Laut. Djambatan, Jakarta.

Rosidah, Afizia W. Potensi ekstrak daun jambu biji sebagai antibakterial untuk menanggulangi serangan bakteri Aeromonas hydrophila pada ikan gurame (Osphronemus gouramy lacepede). Jurnal akuatika. 2012;3(1):p.24

Rosmiati, Suryati, Emmed., 2001, Isolasi dan Identifikasi Senyawa Bioaktif Sponge (Callyspongia pseudoreticulata) terhadap bakteri patogen dan udang, Jurnal Bioteknologi Pertanian, 6, 16-21, Balai Penelitian, Maros.

Ruppert, E. E., and Barnes, R. D., 1991, Invertebrates Zoology, Sixth Edition, Saunders College Publishing, Philadelphia, New York, Chicago, San Fransisco, Montreal, Toronto, London, Sidney, Tokyo, 68 - 91.

Ryan, M.J. 2007. Novel Secondary Metabolites from New Zealand Marine Sponges. University of Wellington, Victoria 
Sandoval, I. T., Davis, R. A., Bugni, T. S., Concepcion, G. P., Harper, M. K., and Ireland, C. M., (tanpa tahun), Cytotoxic Isoquinoline Quinones from Spons of the Genus Petrosia

Sapar, A. dan Kumanireng, A. S., 2004, Isolasi dan Penentuan Struktur Metabolit Sekunder Aktif Dari Sponge Biemma Triraphis Asal Pulau Kapodasang (Kepulauan Spermonde), Marina Chimica Acta 2004, 6 (1), Makassar.

Sari L. Pemanfaatan obat tradisional dengan pertimbangan manfaat dan keamanannya. Majalah Ilmu Kefarmasian. 2006;3(1): p.1-7

Satari, RR, 2009, Penelitian Produk Bahan Alam Laut Di Indonesia, Arah dan prospek: Seminar Nasional Kimia Bahan Alam. Jakarta. Siagian, A. 2002., Bahan Tambahan Makanan, Medan: Universitas Sumatera Utara.

Satari, RR, Penelitian Produk alam laut di Indonesia, arah dan prospek, Seminar Nasional Kimia Bahan Alam, Jakarta 1999, 29-37.

Setyowati, E. P., et al., 2007. Isolasi senyawa sitotoksik spons Kaliapsis sp, Majalah Farmasi Indonesia, vol 18 (4) 183-189

Setyowati, E. P., Jenie, U. A., Sudarsono, Kardono, B., Rahmat, R., dan Meiyanto, E., 2007, Isolation of Cytotoxic Substance From Kaliapsis Spons, Majalah Farmasi Indonesia, 18 (4), 183-189.

Setyowati, E.P., Sudarsono, Wahyuono, S., 2003, Active Fraction from Sponge Stylissa flabelliformis Collected from Menjangan National Park West Bali, Journal of Technoscience, 16, 499-513.

Setyowati, E.P., Sudarsono, Wahyuono, S., 2004, Cytotoxic and Antimicrobial Test of The Bioactive Compound Isolated from Stylissa flabelliformis Sponge, Indonesian Journal of Pharmacy, 15, 50-56

SmallCrab.com. 2008. Karakteristik Candida albicans. http://www.smalcrab.com/ kesehatan/25--healthy415-karak-candida-albicans . Diakses 20 Agustus 2009.

Smith A, Robertson D, Tang M, Jackson M, MacKenzie D, Bagg J. Staphylococcus aureus in the oral cavity: a three-year retrospective analysis of clinical laboratory data. British dental journal. 2003; 195(12): p.701-3

Smith AJ, Jackson MS, Bagg J. The ecology of Staphylococcus species in the oral cavity. J Med Microbiol. 2011; 50(11): p.940-6

Soediro, I.S., 1999, Produk Alam Hayati Bahari dan Prospek Pemanfaatannya di

Soest, R. W. M., Van, and Braekman, J. C., 1999, Chemosystematics of Porifera: A Review, Memoir of the Queensland Museum, 44, 569 -589.

Sorokin YI, 1993, Coral Reef Ecology, Berlin: Springer - Verlag, 173-182. Tapan, E., 2005, Kanker, Antioksidan dan Terapi Komplementer, Jakarta, PT Elex Media Komputindo.

Storr, 1976. Ecological; Factors controlling sponge distribution in the gulf of Mexicomand the resulting zonation. In F.W. Harrison and R.R. Cowden (Eds). Aspec of sponge Biology. A Subsidiary of Harcourt Brace Jovanovich, Publishers. Academic press. New York. San Fransisco. London.p.261-276.

Sudirman, S., 2011, Aktivitas Antioksidan Dan Komponen Bioaktif Kangkung Air (Ipomoea Aquatica Forsk), Departemen Teknologi Hasil Perairan Fakultas Perikanan Dan Ilmu Kelautan Institut Pertanian Bogor, Bogor.

Suharyanto, 1998. Studi Distribusi dan Persentasi Penutupan Spons Pada Kedalaman dan Kondisi Terumbu Karang yang Berbeda di Perairan Pulau Barrang Lompo. Program Pascasarjana Universitas Hasanuddin. 
Suharyanto, A. Parenrengi dan E. Suryati. 1997. Kelimpahan Sponge Pada Kedalaman yang berbeda di Perairan Teluk Labuange Kabupaten Barru. Sulawesi Selatan. Laporan Penelitian. Balai Penelitian Perikanan Pantai, Maros. 10 hal.

Suharyanto. 2008. Distribusi dan Persentase Tutupan Sponge (Porifera) pada Kondisi Terumbu karang dan Kedalaman yang Berbeda di perairan Pulau Barranglompo, Sulawesi Selatan. Biodiversitas 9: 2009- 212.

Suparno, 2005, Kajian Bioaktif Spons Laut (porifera: Demospongiae) Suatu Peluang Alternatif Pemanfaatan Ekosistem Karang Indonesia Dalam Dibidang Farmasi, Jurnal Perikanan Indonesia, 24(21), 41-45.

Suparno, et al., 2009, Transplantasi spons laut Petrosia nigricans, jurnal Ilmu Kelautan, Vol 14 (4): 234-241

Suratmo, 2009, Potensi Ekstrak Daun Sirih Merah (Piper Crocatum) Sebagai Antioksidan, (Online) (http://fisika.ub.ac.id/bssub/PDF\%20FILES/BSS_ 205_1. pdf), diakses pada tanggal 12 Februari 2011 jam 17.00 WITA).

Suryati, E., Parenrengi, A., dan Rosmiati, 2000, Penapisan Serta Analisis Kandungan Bioaktif Spons Clathria sp. yang efektif sebagai Antibiofouling pada teritif (Balanus amphitrit), Jurnal Penelitian Perikanan Indonesia, 5 (3).

Sutedja, L., Udin, L. Z., dan Manupputy, A., 2005, Antimicrobial Activity of the Spons Petrosia contignata Thiele, Sistem Informasi Dokumen Kegiatan Pusat Penelitian Kimia LIPI, Bandung.

Suwignyo, S., B. Widigdo, Y. Wardiatno dan M. Krisanti. 2005. Avertebrata Air Jilid 1. Penebar Swadaya, Jakarta.

Syahrurachman A, Chatim A, Soebandrio A, Karuniawati A, Santoso A, Harun B, et al, editors. Buku ajar mikrobiologi kedokteran. Edisi revisi. Jakarta: Binarupa Aksara publishers. 2010; p.125-34

Tarumingkeng et al., 2005

Tomascik, T., A.J. Mah, A. Nontji, and M. K. Moosa, 1997. The Ecology of the Indonesia Seas. Part One. The Ecology of Indonesian Series Vol. VII. Periplus Edition (HK) Ltd.

Trilaksani, W., 2003, Antioksidan: Jenis, Sumber, Mekanisme Kerja Dan Peran Terhadap Kesehatan ogor, Sekolah Pascasarjana, Institut Pertanian Bogor.

Usman, H., Hakim, E. H., Achmad, S.A., Syah, Y. M., Harlim, T., Jalaluddin, M. N. 2005. Jurnal Matemaika dan Sains ITB. 10 (3): 97-100.

Voogd, N. J., De., and Van Soest, R. W. M., 2002, Indonesian Sponss of the Genus Petrosia, Zool. Med. Leidan 76.

Wang, SY., 2006, Fruits with High Antioxidant Activity as Functional Foods, Processing Technologies, Boca Raton: CRC Press, 371-413.

Warren, L., 1982, Encyclopedia of Marine Invertebrates, Di dalam: Walls JG (ed.), 15 28.

Webster, N. 2003. Sponges (http://www.aad.gov.au/default.asp/ ? casid = 5942. Diakses 19 Agustus 2009.

Wetzel, R.G. 1975. Limnology. W.B. Saunders Co. Philadelphia, Pennsylvania.

Widjoyo, 2001. Zoologi Dasar, Erlangga, Jakarta.

Winarno, FG., 2008, Kimia Pangan dan Gizi, M-BRIO Press, Bogor. Winarno, FG., Fardiaz, S., dan Fardiaz, D., 1980, Pengantar Teknologi Pangan, PT Gramedia, Jakarta.

Winarsi, H., 2007, Antioksidan Alami \& Radikal Bebas, Kanisius, Yogyakarta.

Wulandari R, Utami P, Hartanti D. Penapisan fitokimia dan uji aktivitas antibakteri ekstrak etanol herba pulutan (Urena lobata Linn.) Pharmacy.2009;6(1): p.5 
Blogspot: Mynewismailmzblogspot.com, URL:

https://www.blogger.com/blogger.g?blogID=1861852228187613051\&pli=1\#all posts

Marzuki, I., 2017. Paramater Biodegradasi Mikroorganisme terhadap Komponen Hidrokarbon.

https://www.blogger.com/blogger.g?blogID=1861852228187613051\&pli=1\#edit or/target=post;postID=6449632648280124050; onPublishedMenu=overviewstats; onClosedMenu=overviewstats;postNum $=3 ; \mathrm{src}=$ postname

Marzuki, I., 2017. Klebsiella Pneumoniae merupakan mikrosimbion Spons Callyspongia Vaginalis.

https://www.blogger.com/blogger.g?blogID=1861852228187613051\&pli=1\#edit or/target=post;postID=3592224487950791239;onPublishedMenu=overviewstats; onClosedMenu=overviewstats;postNum $=4 ; \mathrm{src}=$ postname

Marzuki, I., 2017. Klebsiella Pneumoniae merupakan mikrosimbion Spons Callyspongia Vaginalis.

https://www.blogger.com/blogger.g?blogID=1861852228187613051\&pli=1\#edit or/target=post;postID=3592224487950791239;onPublishedMenu=overviewstats; onClosedMenu=overviewstats;postNum $=4 ; \mathrm{src}=$ postname

Marzuki, I., 2017. Spons, Hewan Unik yang Dinamis. https://www.blogger.com/blogger.g?blogID=1861852228187613051\&pli=1\#edit or/target=post;postID=7737327947773802253;onPublishedMenu=overviewstats; onClosedMenu=overviewstats;postNum=5;src=postname

Marzuki, I., 2016. Mekanisme Pembentukan Mikrosimbion Spons. https://www.blogger.com/blogger.g?blogID=1861852228187613051\&pli=1\#edit or/target=post;postID=5771962407420069383;onPublishedMenu=overviewstats; onClosedMenu=overviewstats;postNum=16;src=postname

Marzuki, I., 2016. Bakteri Pseudomonas sp dapat mendegradasi Komponen Hidrokarbon Alifatik dari Limbah Sludge.

https://www.blogger.com/blogger.g?blogID=1861852228187613051\&pli=1\#edit or/target=post;postID=1860080032320941741;onPublishedMenu=overviewstats; onClosedMenu=overviewstats;postNum $=18 ;$ src=postname

Marzuki, I., 2016. SPONGE DI KEPULAUAN SPERMONDE ADALAH ANUGRAH TUHAN YANG HARUS DIJAGA UNTUK MASA DEPAN KITA SEMUA, ANAK CUCU ADAM.

https://www.blogger.com/blogger.g?blogID=1861852228187613051\&pli=1\#edit or/target=post;postID=4990286399095417047;onPublishedMenu=overviewstats; onClosedMenu=overviewstats;postNum=19;src=postname

Marzuki, I., 2016. Isolasi dan purifikasi bakteri simbion spons Callyspongia sp. https://www.blogger.com/blogger.g?blogID=1861852228187613051\&pli=1\#edit or/target=post;postID=8850724367647817491;onPublishedMenu=overviewstats; onClosedMenu=overviewstats;postNum=21;src=postname

Marzuki, I., 2016. Komposisi komponen biomassa sel spons Callyspongia sp. https://www.blogger.com/blogger.g?blogID=1861852228187613051\&pli=1\#edit or/target=post;postID=2745272137247853800;onPublishedMenu=overviewstats; onClosedMenu=overviewstats;postNum=22;src=postname

Marzuki, I., 2016. Potensi Kandungan Metabolik Sekunder Spons dari Kepulauan Spermonde 
https://www.blogger.com/blogger.g?blogID=1861852228187613051\&pli=1\#edit or/target=post;postID=1980570822038290888;onPublishedMenu=overviewstats; onClosedMenu=overviewstats;postNum $=25 ;$ src $=$ postname

Marzuki, I., 2016. Analisis histomorfologi dan penentuan spesies sampel spons. https://www.blogger.com/blogger.g?blogID=1861852228187613051\&pli=1\#edit or/target=post;postID=1587533065395360912;onPublishedMenu=overviewstats; onClosedMenu=overviewstats;postNum=26;src=postname

Marzuki, I., 2016. Potensi Pergeseran Peraiaran Kepulauan Spermonde, Khususnya Pulau Kecil Sekitar Makassar Akibat Reklamasi.

https://www.blogger.com/blogger.g?blogID=1861852228187613051\&pli=1\#edit or/target=post;postID=6126895503376831271;onPublishedMenu=overviewstats; onClosedMenu=overviewstats;postNum $=28 ; \mathrm{src}=$ postname

Marzuki, I., 2016. Tranplantasi Sponge Ex situ.

https://www.blogger.com/blogger.g?blogID=1861852228187613051\&pli=1\#edit or/target=post;postID=4067118875394877844;onPublishedMenu=overviewstats; onClosedMenu=overviewstats;postNum=36; src=postname

Marzuki, I., 2016. SPONS, PENYELAMAT LINGKUNGAN TERCEMAR https://www.blogger.com/blogger.g?blogID=1861852228187613051\&pli=1\#edit or/target=post;postID=559497849631540171;onPublishedMenu=overviewstats;o nClosedMenu=overviewstats;postNum $=47 ; \mathrm{src}=$ postname

\section{Ucapan Terima Kasih:}

Ucapan terima kasih disampaikan kepada Direktur Jenderal Penguatan Riset dan Pengembangan Kemenristek Dikti RI atas pembiayaan penulisan buku ini dengan judul: Eksplorasi Spons Indonesia: Seputar Kepulauan Spermonde, melalui skema PPT-2017 (Tahun pertama) dan PSN-2018 (tahun kedua) dalam tiga tahun usulan penelitian. 


\section{Glosarium}

Aktivator; molekul/material organik yang dapat meningkatkan aktivitas/proses kerja untuk mempercepat tercapainya hasil

Adenosin Trifosphat (ATP); nukleotida sebagai satuan molekuler biokimia untuk pertukaran energy intraseluler

Antibakteri; zat yang mengganggu pertumbuhan atau dapat mematikan bakteri dengan cara merusak proses metabolisme mikroba yang merugukan

Antifungi atau antijamur; golongan zat yang bersifat fungisidal yang berguna untuk mencega mikosis akibat infeksi sistemik.

Antikanker; zat yang dapat menghambat/mengganggu/merusak metabolism perjalanan hormon atau pembelahan sel/kelainan siklus sel

Antioksidan; molekul yang mampu memperlambat/mencegah proses oksidasi molekul lain sehingga tidak terjadi reaksi berantai

Aseksual; pewarisan genetik dari satu induk atau keturunan dari orang tua tunggal

Atol; terumbu karang berbentuk cincin atau tapal kuda dilihat dari atas, terjadi karena menurunnya permukaan batuan atau menaik permukaan air laut

Bakteri eksogenous; isolasi bakteri dipermukaan tubuh

Bakteri indigenous; isolasi bakteri dalam tubuh

Berasosiasi; Hidup bersama organisme/mikroorganisme dalam interaksi metaboliems dalam waktu panjang

Bioadsorpben; zat yang terlarut dalam cairan yang dapat menjerap/membentuk ikatan ionik semu dipermukaan melalui reaksi kimia yang berkaitan dengan hal hidup

Bioabsorpsi; penyerapan fisik atau kimia berkaitan pada yang hidup

Bioaktivitas; material esensial/ non esensial yang ada di alam menjadi bagian rantai makanan bekerja,berpengaruh terhadap kesehatan manusia

Biodegradasi; zat sejenis enzim diproduksi organisme hidup yang mampu merombak bahan organik

Biomaterial; bentuk zat kompleks spesifik hasil rekayasa yang dapat digunakan sebagai control interaksi dalam system kehidupan atau lingkungan

Center Point of Indonesia; bagian penting Indonesia dalam area tertentu

Cuplikan; pengambilan bagian kecil material/objek/sampel yang dianggap mewakili sebagian besar material/sampel untuk analisis selanjutnya

Daya hambat; zat yang mengganggu pertumbuhan atau mematikan bakteri/organisme lain dengan mekanisme menrusak metabolis mikroba yang merugikan

Degradasi; destruksi atau perombakan molekul organik dengan merusak struktur

Destinasi; segala sesuatu yang memiliki daya Tarik, keunikan, ciri khas untuk dikunjungi/didatangi oleh orang

Destruksi; perombakan atau penggeseran, penggantian bahan organik tertentu agar dapat dianalisis

Diterpen; golongan senyawa organik terbentuk sekitar 4 molekul hidrokarbon (monoterpene), "di" berulang 2 kali 
Dosis; kadar zat (kimiawi, fisik, biologis) yang dapat mempengaruhi kerja biologis organisme

Ekosistem; buhungan timbal balik tak terpisahkan makhluk dihup dengan lingkungan dalam system ekologi

Eksploitasi; pemanfaatan berlebihan atau sewenang-wenang terhadap subjek untuk kepentingan tertentu

Eksplorasi; Tindakan penemuan dengan pencarian, penjelajahan

Ekstraksi; pemisahan zat/komponen berdasarkan perbedaan kelarutan dua jenis cairan

Endemik; kelajuan konstan cukup tinggi mempengaruhi populasi/berdampak negatif pada tertentu

Endositosis; transfor materi sangat kecil ke dalam sel dengan membentuk vesikula dan membrane plasma

Enzim; biomolekul berupa senyawa jenis protein dapat mempercepat proses reaksi/biologis berlangsung secara siklus tanpa habis bereaksi

Evaporasi; proses perubahan molekul keadan cair menjadi gas terjadi spontan, atau lenyapnya cairan berangsur-angsur ketika terpapar pada gas

Farmakognosi; bagian tanaman atau hewan yang berpotensi sebagai obat alami Fase diam; fase/media yang dilalui fase gerak untuk membawa memisahkan komponen berdasarkan kekuatan adsorpsinya

Fase gerak; larutan pengembang yang merambat, melalui fase diam sehingga komponen sampel terpisah sesuai perbedaan kekuatan adsorpsi

Fase; masa atau tingkatan perkembangan/perubahan

Fenotip; sifat yang tampak atau terekpresikan dari objek tertentu

Filter feeder; kelompok hewan pemakan suspensi atau cara makan dengan menyaring material tersuspensi dalam air

Filtrat; pembersihan/pemisahan partikel padat dari proses fluida dengan melewatkan pada medium penyaringan atau septum, dimana bagian di atasnya mengendap

Fisiologi; system biologi makhluk yang mempelajari keberlangsungan kehidupan

Fitoplanton; komponen autotroph planton yang mampu menyediakan makanan sendiri berupa bahan organik dengan bantuan energy matahari/kimia

Fragmen; cuplikan, petikan atau hasil rasterisasi bagian organ dari keseluruhan tubuh

Fraksi; bagian kecil dalam rasio suatu subtansi dengan massa tertentu

Fraksinasi; teknik pemisahan bagian sel dengan metode homogenisasi atau pemecahan sel melalui sentrifugasi bagian sel dalam dua fraksi yaitu pellet dan supernatan

Gemmula; polong hidup dari spons

Genom; keseluruhan informasi genetik (asam nukleat) yang dimiliki suatu isolat/sel/organisme

Genotip; kode genetik atau turunan sifat dalam sel dari individu yang mempengaruhi 
Gram negatif; bakteri yang menghasilkan merah/merah muda pada saat proses pewarnaan gram karena berpedaan struktur dinding sel

Gram positif; bakteri yang mempertahankan zat warna Kristal jingga/ menghasilkan warna biru/ungu pada saat proses pewarnaan gram karena berpedaan struktur dinding sel

Habitat; tempat menetap untuk hidup

Hawa-nya binatang; jenis hewan dipandang tertua dapat membela diri

Hidrofob; sifat fisik suatu molekul yang ditolak (tidak ada daya tarikan) oleh massa air

Karbonoklastik; jenis bakteri yang dapat mengurail merombak senyawa/komponen hidrokarbon dengan cara digunakan sebagai sumber energy

Konsorsium bakteri; sekelompok bakteri yang memiliki sifat/ kemampuan sama dalam perombakan komponen toksik

Konsorsium karbonoklastik; sekelompok bakteri yang memiliki sifat mengurai/ merombak senyawa/komponen hidrokarbon dengan cara digunakan sebagai sumber energy

Histomorfologi; studi bentuk organisme dan anatomi sel dan jaringan tumbuhan atau hewan menggunakan mikroskop elektron

Imunostimulan; zat yang memiiki stimulin/ merangsang

Imunostin; zat yang memberi efek kekebalan

Inhibitor; zat yang berkemampuan menghambat atau menurunkan laju reaksi

Isolasi; pemisahan penarikan bahan yang diinginkan dari objek

Isolat; ekstrak, bahan tertentu yang terpisahkan dari objek asalnya

Karang batu; ikan karang yang mempunyai kerangka berkapur dan keras

Karang lunak; ikan karang yang tidak mempunyai kerangka, tubuhnya bergerakgerak oleh arus dan gelombang air

Karsinogenik; zat penyebab penyakit kanker

Kodingareng Keke; pulau dalam gugusan kepulauan Spermonde

Koloni; populasi mikroorganisme (bakteri) yang menguasai tempat tertentu

Kontaminasi; terpapar, dikotori, percampuran, perusakan bahan yang mendatangkan efek tidak baik

Kromatografi; teknik pemisahan komponen (molekul) berdasarkan perbedaan pola pergerakan dua fase (fase gerak dan fase diam) yang berada dalam larutan

Krustasea; udang-udangan, kelompok hewan artropoda

Kultur; metode memperbanyak mikroba pada media kultur dengan pembiakan yang terkendali agar organisme berkelimpahan

Lendir spons; zat yang diproduksi oleh mikrosimbion spons untuk mengatasi efek sedimentasi di area habitat

Lingkungan Ekstrik; lingkungan spesifik hanya didiami organisme tertentu

Logam berat; jenis logam dengan (nomor, densitas, bobot) atom tinggi

Loganoklastik; jenis bakteri yang memiliki sifat dapat mereduksi sifat toksik/ mengabsorpsi logam berat 
Maserasi; proses perendaman/penyarian simplisia/sampel menggunakan pelarut organik pada temperatur ruangan, dimana terjadi pemecahan dan pergerakan molekul melalui dinding membran karena perbedaan tekanan osmosis akibat perbedaan konsentrasi

Metabolik sekunder; senyawa non esensial bagi pertumbuhan organisme, ditemukan dalam bentuk unik dan berbeda antara spesies yang satu dengan lainnya.

Mikrosimbion; hidup besama dan berinteraksi biologis antara dua mikroorganisme/organisme dalam jangka waktu panjang

Mikrosimbion; interaksi biologi bersama antara mikroorganismelorganisme

Mikroskopik; keadaan atau objek yang tidak bisa dilihat dengan mata telanjang

Moluska; hewan laut selomata bertubuh lunak

Morfologi; bentuk organisme hewan atau tumbuhan

Mutagenik; perubahan/mutasi susunan genetic DNA maupun RNA

Nonpolar; jenis senyawa yang terbentuk akibat adanya ikatan antar elektron pada unsur yang membentuknya

Oceanografi; ilmu bumi yang mempelajari semua dinamika yang terjadi di samudra/ lautan

Osmoregulasi; peristiwa osmotik penyerapan ion menuju keadaan kesimbangan antara tubuh dan lingkungan

Ovipar; perkembangbiakan hewan dengan bertelur

Partisi; Perbandingan kesetimbangan konsentrasi senyawa dalam campuran dua fase yang tak larut

Patogenik; mikroorganisme parasit yang merupakan agen biologis yang menyebabkan penyakit pada inangnya

Pinakosit; sel-sel spons berbentuk pipih dan berdinding tebal

Planton; organisme renik yang bergerak mengikuti arus atau zat renik yang hidup dalam zona pelagik atau hidup pada permukaan samudra, laut dan badan air tawar

Poli Aromatik Hidrokarbon (PAH); molekul organik dibentuk oleh unsur karbon dan hydrogen bentuk siklik aromatik dan hidrofobik

Polip spons; bagian yang ditemukan di filum Cnidaria, berbentuk selinder dan memanjang pada sumbu tubuh berbentuk vas

Polutan; bahan/ benda pencemar yang beradapa pada suatu objek baik langung maupun tidak langsung

Polymerase Chain Reaction (PCR); metode in vitro untuk menghasilkan sejumlah fragmen DNA spesifik panjang dan jumlah skuens yang telah ditentukan

Predator spons; pemangsa binatang yang berburu dan memangsa binatang lain, contoh cnidaria

Radikal bebas; molekul yang mempunyai electron tidak berpasangan atau kehilangan satu buah electron dari pasangan electron bebas sebagai hasil pemisahan homolitik ikata kovalen

Reduksi; pengurangan atau penuruan sifat racun bahan kimia

Reef fishes; istilah ikan karang tidak dikenal di dalam publikasi ilmia 
Reklamasi; membuat daratan baru dengan menimbun

Rendemen; hasil perhitungan dengan membagi jumlah produk yang diperoleh dalam mol atau bobot.

Resisten; system dalam organisme yang memiliki sikap/ perilaku bertahan, menahan, melawan, menentang atau oposisi terhadap ketahanan organisme lainnya

Sekresi; proses membuat atau melepaskan subtansi kimiawi bentuk lendir yang dilakukan oleh kelenjar atau sel tubuh

Sekuensing: Penentuan struktur primer rantai biopolymer tak bercabang

Sentrifugasi; proses pemisahan sel organisme dengan cara pemusingan sehingga akan terbentuk endapat (pellet) dan supernatan

Simbiosis; hidup bersama dan berinteraksi biologis dua organisme/ mikroorganisme dalam jangka waktu panjang

Skrining; penelusuran, penapisan, metode deteksi dini, diagnoselpencarian jejak dan karakter pada objek tertentu

Sludge; lumpur/material semi-padat hasil samping pengolahan minyak bumi

Spermonde; pulau di Makassar menyerupai sperma

Spons laut; porifera, hewan laut vertebrata memiliki sponging atau spicula

Steroid; senyawa organik aktif biologis dibentuk oleh empat cincin dalam konfigurasu molekuler tertentu

Strain; karakteristik atau sifat khusus sebagai penciri bakteri

Substrat; bahan atau spesies kimia/biokimia yang menjadi subjek/lokasi untuk dimodifikasi dan teramati dalam reaksi

Suspensi; campuran fluida mengandung partikel padat/campuran heterogen zat cair dan zat padat yang dilarutkan dalam zat cair

Terpapar; terkontaminasi atau terkotori, ternoda yang dapat menimbulkan efek merugikan terhadap objek paparannya

Terumbu karang; kumpulan hewan karang bersimbiosis dengan tumbuhan alga

Toksit; zat beracun, umumnya diproduksi di dalam sel organisme hidup

Toleransi; Batas maksimum yang dapat diterima dan tidak menimbulkan efek racun atau dampak negatif kontaminasi yang merugikan objek paparan

Topografi; pemetaan atau pengukuran tinggi muka laut relatif terhadap geoid bumi

Totol; diinjeksikan dalam jumlah cuplikan volume kecil pada objek analisis yang sesuai

Transek; Tempat fragmen spons transplantasi

Transplantasi spons; pencangkokan/ penyambungan atau pemindahan jaringan/bagian tubuh tertentu dari spons kebagian/ tempat tertentu untuk dianalisis pertumbuhan dan perkembangannya

Ulasan; penyapuan/ pengolesan zat tertentu pada bagian yang menjadi objek pengamatan

Uniseluler; organisme yang memiliki satu sel, organisme bersel satu

Vivipara; perkembangbiakan hewan beranak atau melahirkan Sedimentasi 
Zat aktif; zat yang diproduksi oleh spons yang dapat bekerja terhadap objek lainnya sifat mematikan, menghambat atau menghidupkan/ mengaktipkan

Zonasi; pembatasan area tertentu agar dapat dikontrol di diamati proses dinamika yang terjadi 


\section{Indeks}

A

Aaptos aaptos; 10, 38, 159, 186.

Achromobacter; 46.

Acropora; 86, 96, 131a, 131b, 183.

Actiniaria;86

Adenosin Trifosphat (ATP); 119.

Aeromonas; 46.

Aktivator; 121.

Alcaligenes; 3, 78, 150.

Alcyonacea; 86a, 86b.

Alcyonium; 86.

Amoebocyt; 15, 40.

Anthozoa; 86, 89.

Antibakteri; 99a, 99b, 101a, 101b, 101c, 102a, 102b, 102c, 102d, 102e, 103a, $103 \mathrm{~b}, 103 \mathrm{c}, 103 \mathrm{~d}, 103 \mathrm{e}, 104,105 \mathrm{a}, 105 \mathrm{~b}, 105 \mathrm{c}, 113,115 \mathrm{a}, 115 \mathrm{~b}, 119$, 144a, 144b, 144c, 145a, 145b, 145c, 145d, 145e, 145f, 145f, 146a, 146b, 146c, 146d, 146e, 146f, 146g, 146h, 147a, 147b, 147c,

Antifungi; 114, 115.

Antikanker; 95, 99, 112, 116, 141, 147, 148a, 148b, 148c, 149,

Antioksidan; 122, 123a, 123b, 123c, 124a, 124b, 124c, 125a, 125b, 125c, 125d, $125 \mathrm{e}, 125 \mathrm{f}, 125 \mathrm{~g}, 126 \mathrm{a}, 126 \mathrm{~b}, 126 \mathrm{c}, 126 \mathrm{~d}, 126 \mathrm{e}$.

Antipatharia; 86.

Arthrobacter; 3, 150.

Aseksual; 4a, 4b, 9a, 9b, 10, 18, 27a, 27b, 27c.

Astrophorida; 9.

Axinellida; 9, 10, 21, 36a, 36b.

Azulleta sp; 21.

\section{B}

Bacillus flexus; 62, 76a, 76b, 77, 79, 80, 151.

Bacillus; 3, 76, 79, 150.

Bakteri eksogenous; 6 .

Bakteri indigenous; 6 .

Base pair; 62, 77.

Berasosiasi; 5, 50, 51a, 51b, 82, 92, 116a, 116b, 116c, 116d, 116e, 117, 119, 130, 146a, 146b, 151.

Bioabsorpben; 133, 151.

Bioabsorpsi; 133, 166.

Bioaktivitas; 96a, 96b, 96c, 101a, 101b, 101c, 103a, 103b, 104, 123, 144a, 144b, 149.

Biodegradasi; 69a, 69b.

BioEdit; 74, 75a, 75b, 76, 78a, 78b, 78c, 79. 
Biomaterial; 113, 133, 153a, 153b, 166, 167.

Brevibacillus; 3, 150.

Brevibacterium; 3, 150.

C

Calcarea; 4a, 4b, 7a, 7b, 16a, 16b, 28a, 28b, 28c, 155.

Callyspongia aerizusa; 22a, 22b, 22c, 37, 46, 90, 91a, 91b, 91c, 91d, 91e, 94.

Center Point of Indonesia; 1, 132.

Ceriantharia; 86.

Choanocyt; 15, 23.

Choanocyte; 8a, 8b, 10, 11, 15, 24, 26a, 26b, 26c, 31.

Chondrilla nuculai (Chondrosiidae); 10.

Chondrosia reniformis; 10.

Cladocalina vaginalis; 37, 43a, 43b, 44, 164.

Clathria (Clathria) basilana; 20.

Clathrina; 7, 28.

Clavularia; 86.

Coelocarteria singaporensis; 37, 43a, 43b, 43c.

Corallimorpharia; 86.

Corynebacterium; 46.

Cuplikan; 144.

Cyanobacteria; 5, 50, 51, 116.

D

Daya hambat; 81a, 81b, 81c, 93a, 93b, 93c, 94a, 94b, 94c, 94d, 94e, 94f, 94g, 95a, 95b, 95c, 95d, 95e, 96a, 96b, 98, 99a, 99b, 99c, 100, 102a, 102b, 104, 105a, 105b, 105c, 106a, 106b, 106c, 145.

Degradasi; 12; 34

Demospongia; 16a, 16b, 25, 28, 29, 36a, 36b, 37a, 37b.

Demospongiae; 4a, 4b, 7a, 7b, 9, 20, 21, 22, 28, 29a, 29b, 29c, 29d, 29e, 33, 34, $35,44,75,118,155 a, 155 b, 155 c, 171$.

Destinasi; 128, 129, 154a, 154b.

Destruksi; 65.

Diterpen; 144a, $147 b$.

Dosis; 145.

$\mathbf{E}$

Ekosistem; 1a, 1b, 1c, 1d, 2a, 2b, 2c, 2d, 83, 85, 89, 116, 129, 131, 139, 163, 174, 176, 177a, 177b, 177c, 178, 180.

Eksploitasi; 3, 130, 132.

Eksplorasi; 1, 2, 3a, 3b, 5, 13, 113, 114, 128, 132, 133a, 133b, 137.

Ekstraksi; 61, 74, 78, 81, 97a, 97b, 97c, 97d, 97e, 97f, 97g, 101, 110, 113, 114, 123a, 123b, 123c, 143a, 143b, 143c, 143d, 143e, 143f, 143g, 146.

Endemik; 140. 
Endositosis; 6 .

Enzim; 3, 38, 51, 61a, 61b, 61c, 72a, 72b, 72c, 72d, 72e, 73a, 73b, 74, 82, 83, $113,115,119 \mathrm{a}, 119 \mathrm{~b}, 119 \mathrm{c}, 119 \mathrm{~d}, 120 \mathrm{a}, 120 \mathrm{~b}, 120 \mathrm{c}, 120 \mathrm{~d}, 120 \mathrm{e}, 120 \mathrm{f}$, $120 \mathrm{~g}, 120 \mathrm{~h}, 120 \mathrm{i}, 120 \mathrm{j}, 120 \mathrm{k}, 120 \mathrm{l}, 120 \mathrm{~m}, 120 \mathrm{n}, 120 \mathrm{o}, 120 \mathrm{p}, 120 \mathrm{q}, 121 \mathrm{a}$, 121b, 121c, 121d, 121e, 121f, 121g, 121h, 121i, 122a, 122b, 122c, 122d, $122 \mathrm{e}, 142,152 \mathrm{a}, 152 \mathrm{~b}, 153,166$.

Epiactis; 86.

Epizoanthus; 87.

Evaporasi; 97, 102.

$\mathbf{F}$

Farmakognosi; 3.

Fase gerak; 98, 101, 107a, 107b, 107c, 107d, 107e, 108a, 108b, 108c, 108d, 108e, 109a, 109b, 110a, 110b, 111a, 111b, 111c, 143a, 143b.

Fase;

Fenotip; 56, 68a, 68b, 68c, 68d, 71a, 71b, 71c, 71d, 72, 74, 77, 78, 128.

Filter feeder; 4, 15, 16, 23, 41, 45, 47, 48a, 48b, 99, 142, 165, 169, 175.

Filtrat; 97a, 97b, 97c, 97d, 97e, 97f, 97g, 97h, 97i, 110a, 110b, 124.

Fisiologi; 17a, 17b, 19a, 19b, 23, 24a, 24b, 25a, 25b, 40, 63a, 63b, 63c, 67, 71a, $71 \mathrm{~b}$.

Fitoplanton; 15, 134, 139, 142a, 142b.

Flagella; 15, 23.

Flavobacterium; 46.

Fragmen; 9, 11, 27a, 27b, 62, 74, 155, 158a, 158b, 159, 160a, 160b, 160c, 160d, 160e, 160f, 160g, 160h, 160i, 160j, 161, 162, 169, 175, 184, 185a, 185b, $185 \mathrm{c}, 187 \mathrm{a}, 187 \mathrm{~b}, 187 \mathrm{c}, 187 \mathrm{~d}$.

Fraksi; 58, 74

Fraksinasi; 65, 66, 98, 100a, 100b, 101a, 101b, 107, 111, 114, 124a, 124b, 124c.

Fungia; 86.

G

Gemmula; 9, 12a, 12b, 12c, 12d, 12e.

Gemmule; 4a, 4b, 10a, 10b, 10c, 10d, 10e, 10f, 12, 18, 27a, $27 b$.

GenBank; 74a, 74b, 75, 76a, 76b, 76c, 76d, 77, 78a, 78b, 78c, 79a, 79b, 80a, $80 b$,

Genom; 77a, 77b, 77c, 77d.

Genotip; 68, 71, 74a, 74b, 74c, 74d, 75a, 75b, 77, 79.

Gorgonacea; 86.

Gorgonia; 86a, $86 b$.

Gram negatif; 69, 96a, 96b, 102a, 102b, 105a, $105 \mathrm{~b}$.

Gram positif; 68, 69a, 69b, 96, 105a, 105b.

Grantia; 7. 


\section{$\mathbf{H}$}

Habitat; 4a, 4b, 18a, 18b, 29, 42, 43, 47, 48, 50, 56, 58, 81a, 81b, 85, 88, 89a, 89b, 89c, 90a, 90b, 90c, 90d, 90e, 91a, 91b, 91c, 93a, 93b, 94, 95a, 95b, 95c, 95d, 96a, 96b, 96c, 96d, 96e, 106a, 106b, 129, 136, 137, 142a, 142b, 151, 155, 159a, 159b, 159c, 159d, 159e, 159f, 159g, 159h, 164, 174, 176, 177a, 177b, 177c, 177d, 177e, 178, 179a, 179b, 179c, 184, 187.

Hadromerida; 9, 10a, $10 \mathrm{~b}$.

Haliclona oculata; 37, 43, 44.

Haliclona; 105a, 105b, 105c, 105d, 106.

Hawa-nya binatang; 12.

Heliopora (ordo Helioporacea); 86.

Heterotrofik; 5, 51a, $51 \mathrm{~b}$.

Hexactinellidae; 4.

Hexatinellida; 16.

Hidrofob; 174.

Hidrokarbonoklastik; 3, 150a, 150b, 150c.

Histomorfologi; 33, 42, 43a, 43b, 44a, 44b, 44c, 80.

Hyrtios erectus; 20, 46.

\section{I}

Imunostimulan; 116, 117a, 117b.

Imunostin; 116.

Inhibitor; 51, 113, 121, 123.

Isolasi; 5, 6a, 6b, 6c, 6d, 38, 46, 51a, 51b, 42a, 52b, 52c, 52d, 52e, 52f, 52g, 52h, 53a, 53b, 53c, 53d, 53e, 54a, 54b, 55, 56a, 56b, 56c, 57a, 57b, 57c, 57d, 58a, 58b, 58c, 58d, 58e, 62, 68a, 68b, 69, 75, 76a, 76b, 77, 78, 80, 98, 99a, 99b, 108a, 108b, 114a, 114b, 114c, 114d, 117a, 117b, 118a, 118b, 118c, 118d, 119, 121a, 121b, 123, 124, 141, 142, 143a, 143b, 143c, 143d, 143e, 147a, 147b, 147c, 147d, 147e, 148a, 148b, 148c, 148d, 148e, 148f, 148g, $149,150 \mathrm{a}, 150 \mathrm{~b}, 151,169$.

Isolat; 3, 38a, 38b, 52a, 52b, 53, 54a, 54b, 54c, 55a, 55b, 55c, 55d, 55e, 55f, 55g, $55 \mathrm{~h}, 56 \mathrm{a}, 56 \mathrm{~b}, 56 \mathrm{c}, 56 \mathrm{~d}, 56 \mathrm{e}, 56 \mathrm{f}, 56 \mathrm{~g}, 56 \mathrm{~h}, 56 \mathrm{i}, 56 \mathrm{j}, 56 \mathrm{k}, 56 \mathrm{l}, 56 \mathrm{~m}, 56 \mathrm{n}$, 56o, 57a, 57b, 58, 59a, 59b, 59c, 59d, 59e, 59f, 59g, 59h, 59i, 59j, 59k, 60a, 60b, 60c, 60d, 60e, 61a, 61b, 61c, 61d, 61e, 61f, 61g, 61h, 61i, 61j, 61k, 611, 61m, 61n, 61o, 62a, 62b, 62c, 62d, 62e, 62f, 62g, 62h, 62i, 63a, 63b, 64a, 64b, 68a, 68b, 68c, 68d, 68e, 68f, 68g, 69a, 69b, 69c, 69d, 69e, 69f, 69g, 69h, 69i, 71a, 71b, 71c, 71d, 71f, 72a, 72b, 72c, 72d, 72e, 72f, 72g, 72h, 72i, 72j, 72k, 721, 72m, 72n, 72o, 72p, 72q, 72r, 72s, 72t, 72u, 72v, 72w, 72x, 73a, 73b, 73c, 73d, 73e, 73f, 73g, 73h, 73i, 73j, 73k, 73l, 73m, 74a, 74b, 74c, 74d, 74e, 74f, 74g, 74h, 74i, 74j, 74k, 75a, 75b, 75c, 76a, 76b, 76c, 76d, 76e, 76f, 76g, 76h, 77a, 77b, 77c, 77d, 77e, 77f, 78a, $78 \mathrm{~b}, 78 \mathrm{c}, 80 \mathrm{a}, 80 \mathrm{~b}, 80 \mathrm{c}, 80 \mathrm{~d}, 80 \mathrm{e}, 110,121 \mathrm{a}, 121 \mathrm{~b}, 122 \mathrm{a}, 122 \mathrm{~b}, 122 \mathrm{c}$, 122d, 122e, 144a, 144b, 144c, 144d, 144e, 144f, 145a, 145b, 145c, 145d, 
145e, 145f, 145g, 146a, 146b, 146c, 146d, 146e, 146f, 146g, 146h, 146i, $147 \mathrm{a}, 147 \mathrm{~b}, 147 \mathrm{c}$.

Isotonik; 25.

\section{$\mathbf{K}$}

Karang batu; 85a, 85b, 85c, 85d, 85e, 85f, 85g, 85h, 85i, 85j, 85k, 86a, 86b, 86c, $86 \mathrm{~d}, 87 \mathrm{a}, 87 \mathrm{~b}, 183$.

Karang lunak; 50, 85a, 85b, 85c, 85d, 85e, 85f, 85g, 85h, 85i, 85j, 85k, 851, 85m, $86,87,131,132,146 \mathrm{a}, 146 \mathrm{~b}, 146 \mathrm{c}$.

Karbonoklastik; 113, 133.

Karsinogenik; 133a, 133b, 153, 166.

Katalase; 72a, 72b.

Kodingareng Keke; 18, 33, 41, 68, 79, 82a, 82b, 100, 127.

Koloni; 11a, 11b, 11c, 11d, 27, 32, 46, 52a, 52b, 52c, 52d, 53a, 53b, 53c, 53d, 53e, 53f, 53g, 53h, 53i, 53j, 53k, 531, 53m, 53n, 53o, 55a, 55b, 58, 62, 63a, 63b, 63c, 64a, 64b, 69a, 69b, 121a, 121b, 121c, 121d, 121e, 122a, 122b, $122 \mathrm{c}, 122 \mathrm{~d}, 154 \mathrm{a}, 154 \mathrm{~b}, 154 \mathrm{c}$.

Kontaminasi; 3a, 3b, 62.

Koral; 19, 141.

Kromatografi; 98, 101a, 101b, 101c, 101d, 107a, 107b, 107c, 107d, 108a, 108b, $111 \mathrm{a}, 111 \mathrm{~b}, 111 \mathrm{c}, 143 \mathrm{a}, 143 \mathrm{~b}, 143 \mathrm{c}, 143 \mathrm{~d}, 143 \mathrm{e}, 143 \mathrm{f}, 143 \mathrm{~g}, 143 \mathrm{~h}, 144$.

Krustasea; 2.

Kultur; 53a, 53b, 57a, 57b, 57c, 58a, 58b, 77, 78a, 78b, 104a, 104b, 104c, 122, 150 .

\section{$\mathbf{L}$}

Leptogorgia; 86.

Leucosolenia; 7.

Lingkungan Ekstrim; 5, 43, 68, 77.

Lobophyton; 86.

Logam berat;3a, 3b, 32, 48, 49, 81, 113, 114, 119, 121, 133a, 133b, 151a, 151b, $152 \mathrm{a}, 152 \mathrm{~b}, 152 \mathrm{c}, 152 \mathrm{~d}, 152 \mathrm{e}, 152 \mathrm{f}, 153,166 \mathrm{a}, 166 \mathrm{~b}, 166 \mathrm{c}, 166 \mathrm{~d}$.

Loganoklastik; 113.

\section{M}

Maserasi; 97a, 97b, 97c, 97d, 98a, 98b, 100, 110a, 110b, 110c, 123, 143.

Medulla; 39, 40, 41, 66.

Mesenteri; 86a, 86b.

Mesohyl; 5a, 5b, 9a, 9b, 11, 12, 15a, 15b, 26a, 26b, 26c, 31a, 31b, 39a, 39b, 41, $52,67$.

Metabolik sekunder; 89, 153.

Metridium; 86.

Micrococcus; 46, 147, 148. 
Mikrosimbion; 5, 6, 32, 38a, 38b, 44, 45, 47a, 47b, 50, 51a, 51b, 52, 53a, 53b, 54, 56a, 56b, 57, 59, 67, 68a, 68b, 68c, 68d, 68e, 68f, 72a, 72b, 75, 77a, 77b, 77c, 81a, 81b, 81c, 91, 92, 93a, 93b, 93c, 113, 114, 117, 119, 151, 152a, 152b, 153a, 153b, 153c, 153d, 135e, 153f, 153g, 163a, 163b, 163c, 166a, 166b, 167, 169, 174.

Mikroskopik; 54, 121.

Moluska; 2, 15, 141.

Montipora; 86, 183.

Morfologi; 11, 17, 30a, 30b, 30c, 30d, 30e, 32a, 32b, 32c, 32d, 33a, 33b, 34, 37, 38, 39a, 39b, 39c, 39d. 52, 55a, 55b, 56a, 56b, 66a, 66b, 66c, 67a, 67b, 82, 83a, 83b, 83c, 121, 128, 167, 172a, 172b, 172c, 173a, $173 \mathrm{~b}$.

Muricea (orgo Gorgonacea); 86.

Mutagenik; 113, 153, 166.

$\mathbf{N}$

Neopetrosia sp; 22, 37a, 37b.

Niphates sp; 20, 37, 46, 56a, $56 b$.

Nonpolar; 143a, 143b.

\section{$\mathbf{O}$}

Oceanografi; 95.

Octocoralia; 85a, 85b, 86a, 86b, 86c.

Osculum; 7, 15a, 15b, 23, 26a, 26b, 27a, 27b, 135, 172a, 172b, 172c, 172d, 172e, $172 \mathrm{f}, 176$.

Osmoregulasi; 25a, 25b, 25c, 170, 176.

Ovipar; 9a, 9b, 9c, 9d.

$\mathbf{P}$

Palythoa; 87.

Pantai Melawai; 18, 42, 43a, 43b, 43c, 67, 77, 79a, 79b, 105.

Partisi; 98, 101, 107, 110, 111, 114, 123, 143a, 143b, 143c.

Patogenik; 165.

Pennatulacea; 86.

Petrosia; 19, 29, 32, 34, 37, 38, 39a, 39b, 40a, 40b, 40c, 46, 65, 66a, 66b, 66c, 66d, 67a, 67b, 67c, 77, 117a, 117b, 117c, 117d, 117e, 118a, 118b, 118c, $118 d, 118 e, 118 f, 121 a, 121 b, 121 c, 135,159 a, 159 b, 161 a, 161 b, 162$, 184a, 184b, 184c, 184d, 184e, 184f, 184g, 184h, 185a, 185b, 185c, 185d, 185e, 185f, 185g,186a, 186b, 186c, 187a, 187b, 187c, 187d.

Pinacocytes; $7,8 a, 8 b, 8 c, 11$.

Pinakosit; 6a, 6b, 6c.

Planton; 15, 134, 139.

Pocillopora; 86, 183.

Polutan; 152a, 152b, 152c, 152d

Polymastia hirsuta; 10 . 
Polymastiidae; 10.

Polymerase Chain Reaction (PCR); 74.

Porites; 86.

Predator; 6, 8, 11, 18a, 18b, 47, 48, 50, 51, 56a, 56b, 82, 92, 94, 95, 99, 115a, $115 \mathrm{~b}, 118,137,141,142,151,152,171 \mathrm{a}, 171 \mathrm{~b}, 171 \mathrm{c}, 171 \mathrm{~d}, 181 \mathrm{a}, 181 \mathrm{~b}$, 181c, $181 \mathrm{~d}, 83$.

Preparatif; 98a, 98b, 98c, 108a, 108b, 108c, 108d.

Psedomonas; 46.

Pseudomonas; 3, 63, 150, 151,

\section{$\mathbf{R}$}

Radikal bebas; 125, 126a, 126b, 126c.

Reduksi; 38, 65, 113, 120, 126, 133, 150, 151, 133, 166.

Reeffishes; $83 a, 83 b$.

Reklamasi; 1, 14, 15a, 15b, 49a, 49b, 130, 132, 139a, 139b, 139c, 139d, 139e, 140.

Rendemen; 98, 106, 111.

Renila; 86.

Resisten; 96, 99, 101a, 101b, 116.

Resistensi; 96, 146.

$\mathbf{S}$

Sarcophyton; 86, 144, 145, 146a, 146b, 146c, 147.

Scleractinia; 85a, 85b, 85c, 86a, 86b, 87, 89.

Scypha; 7.

Sekresi; 25, 102, 115, 169a, 169b, 171, 174, 185.

Sekuensing; 74a, 74b, 75, 76, 77, 78a, 78b, 78c, 79a, 79b.

Sentrifugasi; 52, 53a, 53b, 53c, 53d, 61a, 61b, 61c, 61d, 65a, 65b, 65c, 65d, 65e, $66 \mathrm{a}, 66 \mathrm{~b}, 124 \mathrm{a}, 124 \mathrm{~b}$.

Sesil; 30, 86, 89, 118, 155.

Shipping; 3.

Simbion;

Simbiosis; 5, 14, 31, 32, 41a, 41b, 41c, 45, 50a, 50b, 50c, 51a, 51b, 51c, 92, 115, $116,166$.

Skrining; 91a, 91b, 141, 142.

Sludge; 3a, 3b, 63a, 63b, 67.

Spermonde; 1a, 1b, 1c, 18, 32, 46a, 46b, 68, 82, 100, 117a, 117b, 124, 127a, 127b, 127c, 128a, 128b, 128c, 128d, 128e, 129a, 129b, 129c, 129d, 129e, 129f, 130a, 130b, 130c, 130d, 134, 136, 142, 158, 159a, 159b, 165.

Spicula; 15a, 15b, 36, 44, 65.

Spirophorida; 68.

Spongocoal; 69.

Spongocoel; 25; 26; 31.

Spongosol; 85 . 
Spons laut; 1, 2a, 2b, 3, 6, 8a, 8b, 11, 12, 14, 17, 30, 97, 102, 16, 118, 136a, 136b, 136c,136d, 136e, 136f, 136g, 136h, 136i, 155a, 155b, 158, 168a, 168b, $173,174,175 \mathrm{a}, 175 \mathrm{~b}, 175 \mathrm{c}, 175 \mathrm{~d}, 178 \mathrm{a}, 178 \mathrm{~b}$.

Steroid; 113, 118a, 118b, 118c, 118d, 118e, 119a, 119b, 119c.

Stichodactyla; 86.

Stolonifera; 86a, 86b.

Strain; 56, 62, 80, 118a,118b.

Stylatula; $86 a, 86 b$.

Substrat; 155a, 155b, 155c, 156a, 156b, 156c, 156d, 157a, 157b, 158, 159a, 159b, 159c, 167a, 167b, 168, 173a, 173b, 177, 178a, 178b, 179a, 179b, 179c, 179d, 182, 183a, 183b, 183c, 184.

Suspensi; 23, 64, 77, 151, 168.

Sycon; 7, 28.

\section{$\mathbf{T}$}

Telestacea; 86.

Tentakel; 86, 109, 110, 111, 112.

Terpapar; 159a, 159b.

Terumbu karang; 49, 94a, 94b, 95, 96a, 96b, 96c, 96d, 118, 129a, 129b,129d, 129d, 163, 174, 176a, 176b, 176c, 177a, 177b, 177c, 177d, 177e, 177f, $177 \mathrm{~g}, 177 \mathrm{~h}, 177 \mathrm{i}, 177 \mathrm{j}, 178 \mathrm{a}, 178 \mathrm{~b}, 178 \mathrm{c}, 178 \mathrm{~d}, 178 \mathrm{e}, 178 \mathrm{f}, 178 \mathrm{~g}, 178 \mathrm{~h}$, 178i, 179a, 179b, 179c, 179d, 180a, 180b, 180c, 180d, 180e, 180f, 180g, 180h, 180i, 180j, 180k, 180, 18; 184a, 184b.

Tethya auratum; 10a, 10b.

Tethya citrina (Tethydae); 10.

Tethya crypta; 10a, $10 \mathrm{~b}$.

Tetractinomorpha; $9 \mathrm{a}, 9 \mathrm{~b}$.

Toksik; 3, 70, 94, 95, 98, 106, 108a, 108b, 108c, 109a, 109b, 109c, 110, 111, 112a, 112b, 112c, 113, 114, 116, 117, 118, 133a, 133b, 147, 148, 15, 166.

Toleransi; 170, 172.

Topografi; 48a, 48b, 87, 88a, 88b.

Totol; 108a, 108b, 108c.

Transek; 180.

Transplantasi; 128, 140a, 140b, 140c, 155a, 155b, 155c, 155d, 155e, 155f, 156a, $156 \mathrm{~b}, 156 \mathrm{c}, 156 \mathrm{~d}, 157 \mathrm{a}, 157 \mathrm{~b}, 157 \mathrm{c}, 15 \mathrm{~d}, 15 \mathrm{ea}, 158 \mathrm{a}, 158 \mathrm{~b}, 158 \mathrm{c}, 158 \mathrm{~d}$, 159a, 159b, 159b, 159c, 160a, 160b, 162a, 162b, 165a, 165b, 165c, 166, $172 \mathrm{a}, 172 \mathrm{~b}, 172 \mathrm{c}, 173 \mathrm{a}, 173 \mathrm{~b}$.

Tryptopan; 60, 73a, 73b.

Tubipora; 88.

$\mathbf{U}$

Ulasan; 158.

Uniseluler; 3, 51, 116, 163.

Urease; 61, 61b, 72, 73 . 
Veretillum; 86.

Vesikuler; 6.

Vibrio; 21, 46, 144, 147, 148.

Vivipar; 132.

$\mathbf{X}$

Xenia (ordo Alcyonacea); 88a, $88 b$.

Xestospongia berquistia; 10, 11.

Xestospongia; 10a, 10b, 148.

$\mathbf{Z}$

Zat aktif; 51a, 51b, 51c, 81, 82a, 82b, 92a, 92b, 93a, 93b, 96a, 96b, 96c, 113, 114, 119, 122, 133a, 133b, 141, 148, 149a, 149b, 149c, 153.

Zoantharia: $85,86 \mathrm{a}, 86 \mathrm{~b}, 86 \mathrm{c}$.

Zoanthidea; 86.

Zoanthus; 87a, 87b.

Zoantid; 87, 89, 102a, 102b.

Zonasi; 140a, 140b, 126.

Zooxanthellae; 85, 86, 182. 


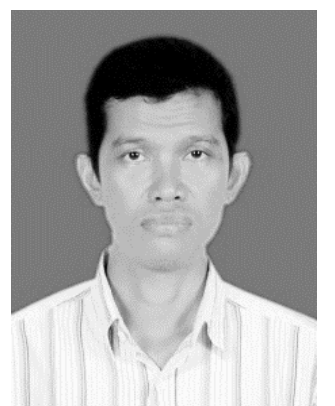

Dr. Ismail Marzuki, S.Si., M.Si, memulai karir sebagai akademisi (tenaga pengajar) sejak tahun 2000 hingga sekarang. Status PNS (Dosen) diperoleh pada Tahun 2005, unit kerja Kopertis wil. IX Sulawesi dipekerjakan pada Akademi Analis Kimia (AAK) Yapika Makassar. Karir pengelola kampus diawali pada Tahun 2002-2003 sebagai Direktur bidang Akademik AAK Yapika, selanjutnya sebagai Direktur AAK Yapika Tahun 2003-2008.

Akhir Tahun 2008-2012, hijrah ke Sekolah Tinggi Ilmi Kesehatan (STIKES) Yapika dalam jabatan Wakil Ketua Bidang Akademik. Saat ini mengabdi pada Universitas Fajar (UNIFA), Makassar sejak Tahun 2015sekarang, Prodi home base Teknik Kimia, Fakultas Teknik Universitas Fajar. Tugas tambahan yang diamanahkan oleh UNIFA adalah Pimpinan Redaksi Jurnal Techno Entrepreneur Acta (2016-sekarang) dan juga Ketua Unit Pusat Karir UNIFA (Tahun 2016-sekarang). Pengalaman menulis buku pertama kali Tahun 2008 dengan judul Kimia Keperawatan, kemudian Biokimia Kesehatan, Lalu Kimia Farmasi, selanjutnya buku berjudul Analisis dan Instrumentasi Kimia, keempatnya merupakan buku ajar. Buku kelima sekaligus buku referensi pertama berjudul Eksplorasi Spons Indonesia: Seputar Kepulauan Spermonde. Materi buku ini merupakan penggalan disertasi hasil penelitian digabung dengan capaian riset seputar spons dalam dua tahun terakhir 2016-2018, sebagai pemenuhan luaran hibah penelitian skema Penelitian Produk Terapan (PPT) dan Penelitian Strategis Nasional (PSN). Penulisan buku ini merupakan seri pertama dari dua seri buku yang direncanakan, sekaligus merupakan realisasi janji dalam proposal hibah penelitian Simlitabmas Ristek Dikti.

Pengalaman menulis lainnya yang dijalani oleh penulis adalah aktif menyampaikan gagasan pada kolom opini Harian Fajar, Blogspot (mynewismailmzblogspot.com) dan diperkuat oleh tempahan menulis artikel ilmiah yang telah dipublikasikan pada jurnal Nasional dan Internasional, juga banyak menghabiskan waktu mendampingi mahasiswa dalam menulis proposal PKM, proposal kewirausahaan mahasiswa.

Riwayat hidup penulis terhitung sejak dilahirkan di sebuah Kampung kecil bernama Kabere-Enrekang, 235 km ke Utara Makassar. Lahir pada 03 Juli 1973. Mengikuti pendidikan formal diawali pada Tingkat Sekolah Dasar Negeri 19 Kabere Tahun 1980-1986, Sekolah 
Menegah Pertama (SMP) Kabere Tahun 1986-1989, dan pendidikan tingkat SMA 1 Enrekang Jurusan Fisika Tahun 1989-1992. Gelar sarjana Sains (kimia) disandang tahun 1993-1999, di Jurusan Kimia F.MIPA UNHAS, dan gelar Magister Sains (M.Si) diraih pada Tahun 2001-2003, di Program Pasca Sarjana Fakultas MIPA UNHAS, sedangkan Program Doktor dijalani pada Tahun 2012-2016, pada Program Pasca Sarjana UNHAS dalam waktu tempu selama 3,4 tahun. 


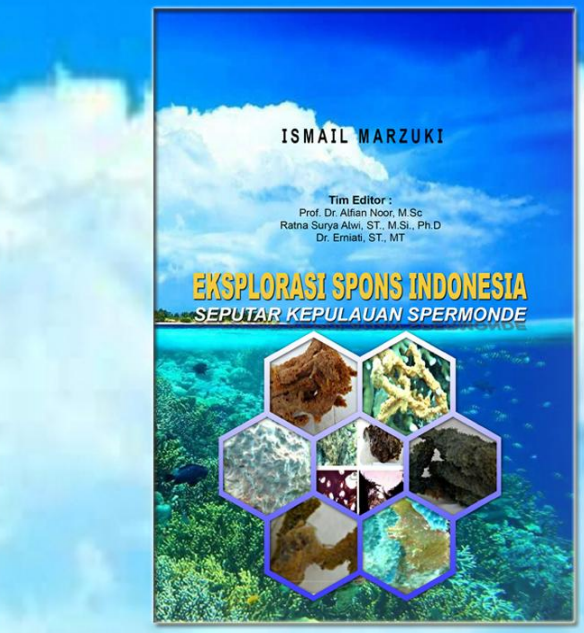

Rencana membukukan disertasi ada sejak awal menyelesaikan studi pada program doktor di awal tahun 2016, termasuk dukungan dan saran beberapa kolega satu profesi, namun rencana ini tidak segera diwujudkan karena terkendala pada kecukupan materi isi dan point-point penting hasil riset yang akan menjadi topik dalam buku ini dan juga merasa bahwa topik yang ada belum cukup bervariasi untuk dijadikan sebagai buku referensi dengan ulasan yang menarik. Kekuatiran ini terjawab ketika dinyatakan sebagai pemenang hibah penelitian skema PPT 2016, dan pemenanh hibah PSN 2017.

Skema hibah simlitabmas mengangkat tema seputar spons dan mikrosimbion yang merupakan kelanjutan dari penelitian disertasi. Buku ini memuat sebagian dari materi disertasi khususnya pada topik identifikasi spons dan mikrosimbioan khususnya analisis morfologi dan histologi spons, analisis biomassa spons dan karakterisasi, analisis fenotip dan analisis genotif mikrosimbion dan potensinya pada pemanfaatan biomassa dan mikrosimbion dalam penanganan limbah. Data yang diperoleh dalam penelitian dua tahun terakhir juga masih seputar isolasi, karakterisasi dan analisis spons dan mikrosimbion, kemudian data-data ini digabung, dan diramu untuk tujuan melahirkan sebuah buku referensi seputar spons. Tambahan data juga diperoleh dari artikel yang termuat dalam jurnal ilmiah yang satu tema dengan isi dari buku ini, dengan demikian praktis buku ini merupakan ringkasan dari banyak artikel jurnal yang kemudian direview oleh penulis yang dilakukan untuk menyajikan topik-topik menarik.

Buku ini terdiri atas 9 bab, yakni: 1) Mengenal Spons Indonesia; 2) Fisiologi, Anatomi, Morfologi dan Histologi Spons; 3) Mikrosimbion Spons; 4) Karakterisasi Spons; 5) Karakteristik Lingkungan, Ekstraksi dan Daya Hambat Mikrosimbion; 6) Potensi Aplikasi Spons dan Mikrosimbion; 7) Sebaran Spons Indonesia dan Ancaman Kepunahan; 8) Spons sebagai Objek Riset Masa Depan, dan 9) Transplantasi Spons.

Penyajian materi setiap Bab, ditulis dalam bahasa sederhana agar mudah dimengerti. Tidak sedikit isi buku ini dalam Bab dilengkapi dengan gambar, tabel dan penjelasan gambar dan tabel agar mudah dalam memahami subtansi dari materi tersebut.
$7-\frac{x}{2}$

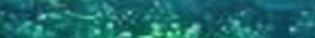

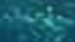

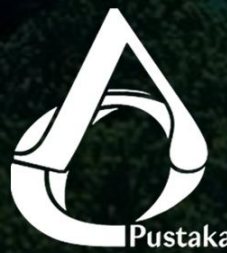

PENERBIT NAS MEDIA PUSTAKA Anggota IKAPI Ji Batua Raya No. 550 Makassar 90233 0853-6363-5252/ 0811-43222-71

redaksi@nasmediabook.com

www.nasmediapustaka.co.id

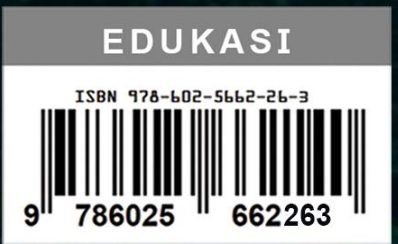

